Historic, Archive Document

Do not assume content reflects current scientific knowledge, policies, or practices. 

099.9

F 76324

$\operatorname{cop} 2$

United States

Department of

Agriculture

Forest Service

Rocky Mountain

Forest and Range

Experiment Station

Fort Collins,

Colorado 80526

Research Paper

RM-272

[0145
Phyto-Edaphic Communities of the Upper Rio Puerco Watershed, New Mexico

Richard E. Francis
琶

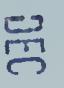

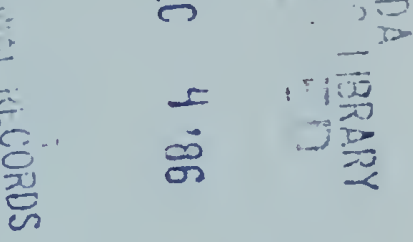




\title{
Phyto-Edaphic Communities of the Upper Rio Puerco Watershed, New Mexico
}

\author{
Richard E. Francis, Range Scientist \\ Rocky Mountain Forest and Range Experiment Station ${ }^{1}$
}

\begin{abstract}
The Upper Rio Puerco Watershed in northwestern New Mexico was classified into 45 ecological phyto-edaphic communities using cluster analysis based on species importance values. The community descriptions consist of vegetation and soil surface characteristics; landform; soil series, association, or complex; ecological stage; and potential natural vegetation. The communities represented 11 vegetation series consisting of 2 treeland, 5 shrubland, and 4 grassland formations. Three soil orders, 27 soil series, nine associations, and three soil complexes were identified. The combination of landform, vegetation, and soil were considered phyto-edaphic communities. A dichotomous key was developed for field identification.
\end{abstract}

\section{Acknowledgments}

Partial financial support for this study was provided by the Bureau of Land Management under Contract No. NMSO-131. 
PHYTO-EDAPHIC COMMUNITY DESCRIPTIONS $\ldots \ldots \ldots \ldots \ldots 10$

Treeland Formation ... Pinus Subformation ...P. ponderosa, P. edulis Series .................. 12

1. Pinus ponderosa/Carex spp.-Bouteloua gracilis p.c ........ 12

2. Pinus edulis- $P$. ponderosa/Bouteloua gracilis-Carex spp. p.c. .... 12

3. Pinus edulis/Bouteloua gracilis-Eriogonum spp. p.c......... 13

4. Pinus edulis-Juniperus monosperma/Opuntia polyacantha/Bouteloua gracilis p.c. ........................ 13

5. Pinus edulis/Quercus gambelii/Hilaria jamesii-Sporobolus nealleyi

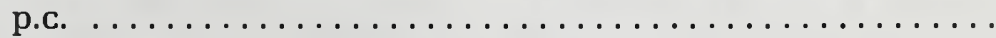

Treeland Formation ... Juniperus Subformation ...J. monosperma Series .......................

6. Juniperus monosperma/Gutierrezia sarothrae/Bouteloua gracilis-

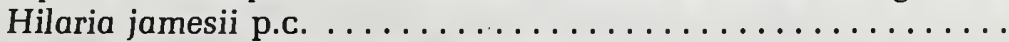

7. Juniperus monosperma/Bouteloua gracilis p.c. ............

8. Juniperus monosperma/Artemisia tridentata/Hilaria jamesii-Sporo-

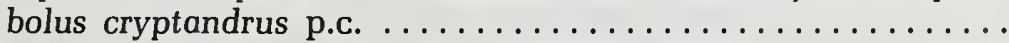

Shrubland Formation ... Artemisia Subformation

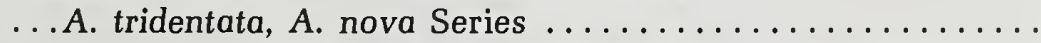

9. Artemisia tridentata/Bouteloua gracilis-Hilaria jamesii p.c. .....

10. Artemisia tridentata-Gutierrezia sarothrea/Bouteloua gracilis-Hilaria

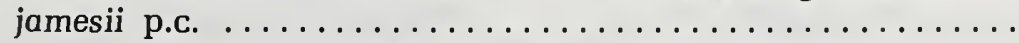

11. Artemisia tridentata/Bouteloua gracilis-Hilaria jamesii-Sporobolus

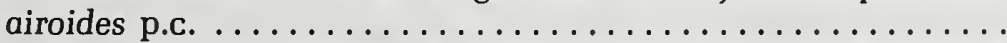

12. Artemisia tridentata-Gutierrezia sarothrae/Hilaria jamesii-Sporobolus

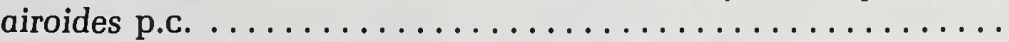

13. Artemisia tridentata-Gutierrezia sarothrae/Bouteloua gracilis-Agro-

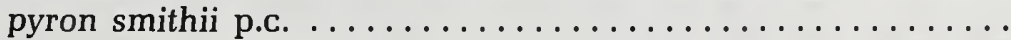

14. Artemisia tridentata/Sporobolus cryptandrus-Oryzopsis hymenoides

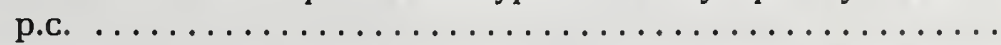

15. Artemisia tridentata-Chrysothamnus parryi/Aristida fendleriana-

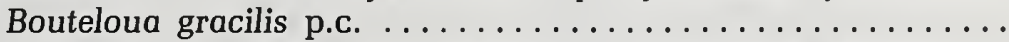

16. Artemisia nova-A. tridentata/Agropyron cristatum-A. smithii p.c.

17. Artemisia nova-Gutierrezia sarothrae/Bouteloua gracilis-Hilaria

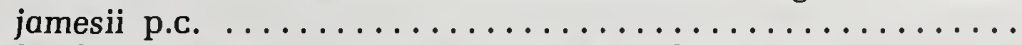

Shrubland Formation ... Chrysothamnus Subformation

...C. nauseosus ssp. bigelovii, C. parryi,

C. nauseosus ssp. graveolens Series ...............

18. Chrysothamnus nauseosus ssp. bigelovii/Bouteloua gracilis-Agro-

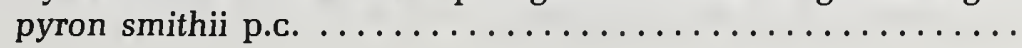


19. Chrysothamnus parryi/Hilaria jamesii-Bouteloua gracilis p.c. ...

20. Chrysothamnus nauseosus ssp. graveolens/Bouteloua gracilis-Agro-

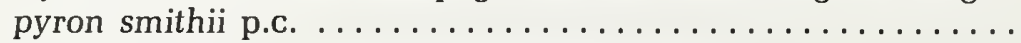

Shrubland Formation ... Sarcobatus Subformation

...S. vermiculatus Series ..................... 19

21. Sarcobatus vermiculatus p.c. .................. 19

22. Sarcobatus vermiculatus/Sitanion hystrix-Agropyron smithii p.c. 19

Shrubland Formation ... Ceratoides Subformation

...C. lanata Series ....................... 20

23. Ceratoides lanata-Gutierrezia sarothrae/Hilaria jamesii p.c. .... 20

24. Ceratoides lanata-Gutierrezia sarothrae/Bouteloua gracilis p.c. .. 20

Shrubland Formation ... Atriplex Subformation

...A. cuneata, A. obovata, A. canescens Series .......... 21

25. Atriplex cuneata-Frankenia jamesii/Sporobolus airoides p.c. . .. 21

26. Atriplex obovata/Sporobolus airoides-S. cryptandrus p.c. ...... 21

27. Atriplex obovata-Gutierrezia sarothrae/Hilaria jamesii-Sporobolus

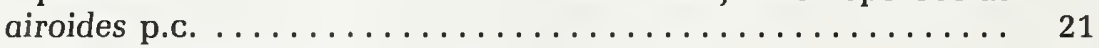

28. Atriplex canescens/Hilaria jamesii p.c. ............. 22

29. Atriplex canescens/Sporobolus airoides-Sitanion hystrix p.c. . . . 22

30. Atriplex canescens-Gutierrezia sarothrae/Bouteloua gracilis-Sporobolus cryptandrus p.c. ................... 22

Grassland Formation ... Bouteloua Subformation

...B. gracilis, B. eriopoda Series ................. 22

31. Bouteloua gracilis-Hilaria jamesii p.c. ............. 23

32. Gutierrezia sarothrae/Bouteloua gracilis-Hilaria jamesii p.c. .... 23

33. Gutierrezia sarothrae/Bouteloua gracilis-B. eriopoda p.c. ...... 23

34. Bouteloua gracilis-Sporobolus airoides p.c. ............. 23

35. Gutierrezia sarothrae/Bouteloua eriopoda-Hilaria jamesii p.c. . . 24

Grassland Formation ... Hilaria Subformation ...H. jamesii Series ....................... 24

36. Gutierrezia sarothrae/Hilaria jamesii-Bouteloua gracilis p.c. .... 24

37. Hilaria jamesii-Sporobolus airoides p.c. .............. 25

38. Gutierrezia sarothrae/Hilaria jamesii-Sporobolus cryptandrus p.c. 25

Grassland Formation ... Sporobolus Subformation ...S. airoides, S. nealeyi Series ................. 25

39. Sporobolus airoides p.c. .................... 25

40. Sporobolus airoides-Bouteloua gracilis p.c. ............ 25

41. Sporobolus airoides-Hilaria jamesii p.c. ............. 26

42. Gutierrezia sarothrae/Sporobolus airoides-Hilaria jamesii p.c. . . 26

43. Sporobolus airoides-Agropyron smithii p.c. ........... 26

44. Sporobolus nealleyi-Bouteloua eriopoda p.c. ........... 27

Grassland Formation ... Scleropogon Subformation

...S. brevifolius Series ..................... 27

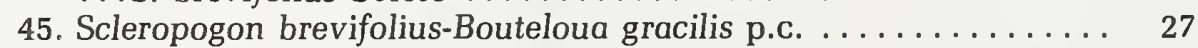

LITERATURE CITED .......................... 27

APPENDIX A.- Modal soil profiles of the Upper Rio Puerco Watershed 57

APPENDIX B.- Plant species of the Upper Rio Puerco Watershed. 61

APPENDIX C.- Key to the plant communities (p.c.) of the Upper Rio Puerco Watershed, New Mexico ............... 66

APPENDIX D. - Terminology $\ldots \ldots \ldots \ldots \ldots \ldots \ldots \ldots \ldots \ldots \ldots \ldots \ldots \ldots$ 


\title{
Phyto-Edaphic Communities of the Upper Rio Puerco Watershed, New Mexico
}

\author{
Richard E. Francis
}

\section{MANAGEMENT IMPLICATIONS}

The phyto-edaphic communities classified on an ecological basis allow for extrapolation of research results to similar environments and provide a base for management prescriptions and interpretation of ecological succession.

The Rio Puerco watershed is a semi-arid basin in northwestern New Mexico. The watershed has a long history of settlement, heavy livestock grazing, and site degradation which began in the mid- to late 1700s (Calkins 1937, Dortignac 1960, Vincent 1984). Research was needed to develop, evaluate, and monitor improved management of the vegetation, livestock, and wildlife resource of the watershed while improving soil stability and water quality ${ }^{2}$.

This study was designed to define, describe, and quantify ecological phyto-edaphic communities on the Rio Puerco watershed. The phyto-edaphic communities will be used as a compatible ecological basis (Francis 1978) to develop and evaluate management schemes, including changes in vegetation, soil surface factors, ecological state, and soil stability. Also, ecological classification was needed to provide criteria for extrapolating quantitative research results and potential subsequent management prescriptions to broader and similar semi-arid environments (Aldon and Garcia 1971), and as a basis for interpreting ecological succession (Huschle and Hironaka 1980, Stewart and Hann 1983).

\section{PLANT COMMUNITY CLASSIFICATION}

Classification of natural communities has been extensively discussed and has had a crucial role in the evolution of ecological theory. Whittaker (1962) reviewed the theory, the meaning, and the problems of natural community classification. Trends in vegetation classification were reviewed by Shimwell (1972), including the polyclimax concept (Tansley 1920) and the monoclimax concept (Clements 1916).

Plant communities are complex phenomena in which there is no single, natural unit of classification (Whittaker 1978). Different systems of classification have been adapted to different kinds of landscapes, vegetation, and interests (Bailey et al. 1978, Daubenmire 1984). Meeker and Merkel (1984) reviewed five climax theories and made a recommendation for vegetation classification. An ideal classification system must be based on readily iden-

${ }^{2}$ USDI Bureau of Land Management. 1977. Final environmental statement: The proposed Rio Puerco livestock grazing management program. 467 p. USDI Bureau of Land Management, Albuquerque, N. Mex. (Mimeo). tifiable elements applicable to all land area for which the concept of potential natural vegetation was proposed rather than the concept of climax; a theoretical past condition (Mueller-Dombois and Ellenberg 1974, Schlatter 1983, Driscoll et al. 1984). Potential natural vegetation allows for the present existing vegetation and site to be projected into the future (Tuxen 1956).

Classification is a basis of comparison with the environment affecting the composition of vegetation, and involves arranging stands into classes which have common characteristics (Greig-Smith 1983). Whether vegetation is perceived as continuous or discrete, is the basis of two theories known as the community concept and the continuum concept (McIntosh 1967, Langford and Buell 1969). Because of topograhic and/or edaphic factors, it is doubtful that ecologists regard or apply either theory in its pure form.

The choice of characteristics used to classify plant communities influences whether the resultant community-types are natural or artificial entities (Whittaker 1962, 1978). Two principles stated by Gleason (1926) and Ramensky (1926) support the idea that discrete communities are often artificial due to arbitrary boundaries: (1) species are distributed individualistically and, (2) plant communities often intergrade continuously. However, Daubenmire (1966) pointed some concrete discontinua that may occur in any vegetation cover over a gradually changing substrate; and McIntosh (1967) reduced the continuum problem as relating only to the abstract community concept. A concrete, regional vegetation cover may show both discontinua or sharp boundaries and gradual pattern or continua changes (Muller-Dombois and Ellenberg 1974).

\section{SOIL CLASSIFICATION}

A system of soil (and/or plant) classification must be dynamic to accept, or even consider new hypotheses and research results. Practical classifications of soils as natural bodies are based on general soil characteristics that can be observed or measured (Simonson 1962), not on external causative factors that are based on inference (Finkl 1982). However, subjective judgments are inevitable in the delineation of classes, because of the ranges of properties within soil populations, and because classifications are based on assumptions that the units are discrete and definable (Finkl 1982). Despite this, the soil units for classifications still are useful for organization and communication (Cruickshank 1972, Finkl 1982).

The principal elements of soil classification have been reviewed (Coffey 1912, Marbut 1922, Muie 1962, Schelling 1970). The evolution of soil classification was divided into five historical periods (Buol et al. 1973). The modern 
period in the United States emphasized the "7th Approximation" (Soil Survey Staff 1960) and culminated in subsequent revision (Soil Survey Staff 1975).

\section{NEW MEXICO VEGETATION}

The southwest desert flora is a derivative of the MadroTertiary Geoflora (Axelrod 1979, Lowe and Brown 1982). The most extensive area of grassland west of the Rocky Mountains is the semi-desert type of New Mexico, Arizona, and northern Mexico (Numata 1979). Soils of this area are in the desertic group, low in organic matter and degree of leaching. The ecology and management of southwestern rangelands have been synthesized (Cable 1975, Clary 1975, Martin 1975, Springfield 1976); and the concept, status, and application of southwestern habitat types and other ecological classifications have been presented and compared (Moir and Hendzel 1973).

Potential natural vegetation of New Mexico was mapped by Donart et al. (1978), including five formations, 13 regions, 20 series, and 67 associations. Six ecoregions (Bailey 1976, 1980) and nine biotic communities (Brown and Lowe 1980, Brown 1982) were mapped at small scales and were described; Castetter (1956) previously described the vegetation of New Mexico. Extensive shifts in desert, grassland, and juniper savanna boundaries in portions of New Mexico have been indicated since the 1800s (York and Dick-Peddie 1969); maps were drawn to reconstruct those New Mexico vegetation patterns (Gross and Dick-Peddie 1979). Grassland communities of east-central New Mexico were classified by Beavis et al. (1982); Moir (1979) described soil-vegetation patterns in the Peloncillo Mountains and subalpine tall grass communities of Sierra Blanca (Moir 1967); Baker (1983) classified the alpine vegetation of Wheeler Peak; and the Bureau of Land Management identified seven vegetation sub-types for the Rio Puerco Watershed ${ }^{2}$. Almost all national forests have been classified into habitat types (Moir and Hendzel 1983); but very few specific shrub and grassland communities have been classified in New Mexico.

\section{STUDY AREA}

The Rio Puerco Watershed is in New Mexico, west of the Jemez Mountains and northwest of Albuquerque; it includes 1.6 million ha. The Rio Puerco is mostly intermittent or ephemeral, with its headwaters from the western slope of the San Pedro mountains.

The specific study area, referred to as the Upper Rio Puerco Watershed, is $64 \mathrm{~km}$ northwest of Albuquerque (fig. 1). It covers about $10 \%$ of the total Rio Puerco Watershed. Approximately 207,172 ha are within the study area, of which 159,080 ha are administered by the Bureau of Land Management (BLM) ${ }^{2}$. Elevations within the study area range from $1,662 \mathrm{~m}$ to $2,743 \mathrm{~m}$.

The Upper Rio Puerco Watershed is along the southeastern edge of the San Juan Basin, which is within the southeastern part of the Colorado Plateau (Baldridge et al. 1983). It is bounded on the southeast by the Rio Puerco

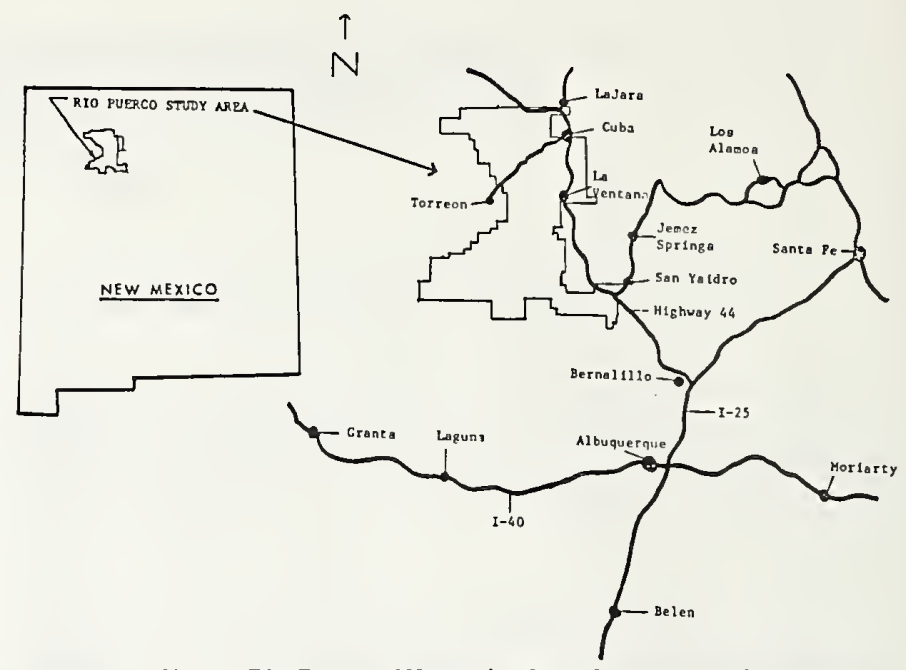

Figure 1.-Upper Rio Puerco Watershed study area, northwest New Mexico.

Fault Zone, and on the east by the Nacimiento Mountains. The east, west, and north are bounded by a continuation of the San Juan Basin. Froehlich et al. $^{3}$ described the geologic history.

The climate of the area is semi-arid (Hanson 1962) with an average annual precipitation from four stations during a 20-year period ranging from $215.9 \mathrm{~mm}$ to $322.6 \mathrm{~mm}$ (fig. 2); the four stations range in elevation from $1,844 \mathrm{~m}$ to $2,195 \mathrm{~m}$, respectively ${ }^{4}$. Peak rainfall was during July, August, and September (fig. 3). Summer rains developed as convectional thunderstorms of short duration, high intensity, and uneven distribution. Twenty-year temperature records indicated that maximum summer temperatures approached $38^{\circ} \mathrm{C}$ and the minimum winter temperature approached $-4^{\circ} \mathrm{C}$. July was the only month on record without frost; the average frost free growing season ranged from 109 days at higher northern elevations to 170 days at the lower southern elevations.

Soils for a portion of the study area were previously described and delineated by Folks and Stone (1968) and later expanded ${ }^{5}$. Most of the soils were classified as Entisols and Aridisols with minor representation from Mollisols and units mapped as Complexes. The precipitation pattern for the study area followed the Ustic soil moisture regime (Buol et al. 1973) (fig. 3).

The study area included 13 range sites (Folks and Stone 1968), of which soils are a major abiotic determinant (Dyksterhuis 1958). The concept of range condition is related to the concept of range site (Humphrey 1947, Renner 1948). The successional status or ecological stage of a community should include soil-site as an interpretation determinant (Reppert and Francis 1973). Shiflet

${ }^{3}$ Froehlich, J. S., B. S. Kues, S. G. Lucas, and R. K. OImo. 1975. Paleontological resource assessment of 500,000 acres in the Rio Puerco grazing environmental impact study area. University of New Mexico, Albuquerque. (Mimeo).

${ }^{4}$ National Oceanic and Atmospheric Administration (NOAA). 1984. Climatological data: New Mexico-special summary. 25 p. U.S. Department of Commerce, NOAA, National Climatic Data Center, Asheville, N. C.

${ }^{5}$ USDA Soil Conservation Service. 1977. Soil survey of BLM lands: Sandoval and McKinley Counties. USDA Soil Conservation Service, preliminary report. Albuquerque, N. Mex. (Mimeo). 
(1973) reviewed the range site concept, history, status, and application.

Donart et al. (1978) listed 4 potential natural vegetation formations, 4 regions, and 10 plant associations for the general study area. The BLM designated nine vegetation sub-types ${ }^{2}$ within the study area which offer general classification information.

The most common naturally occurring soil problems include wind and water erosion associated with sandstone and shale parent materials, low available soil moisture, and soil textures with high sand or clay content $^{2}$. Clayey textured soils in the study area have high shrink-swell potentials, slow infiltration rates, and reduced available soil moisture for plant growth. Sandy soils have excessive drainage, making them subject to wind erosion when dry. Sediment yields varied depending on the area ${ }^{6}$, vegetation, soil, measurement period, and measurement procedure (Burkham 1960, Aldon and Garcia 1973).

\section{METHODS}

\section{DATA COLLECTION}

To maintain compatibility with recommended classification elements (Brown et al. 1979, Driscoll et al. 1984), landform, soils, and vegetation were used to identify phyto-edaphic sites for sampling and as a basis for classification. Hickey and Garcia (1964) identified uplands, breaks, and alluvial landform classes on a semiarid rangeland. Based on their findings, the following five expanded landform classes were used.

6USDI Soil Conservation Service. 1974. Upper Rio Grande Basin - water and related land resources, New Mexico. Regional Technical Center, Portland, Oreg. (Mimeo).
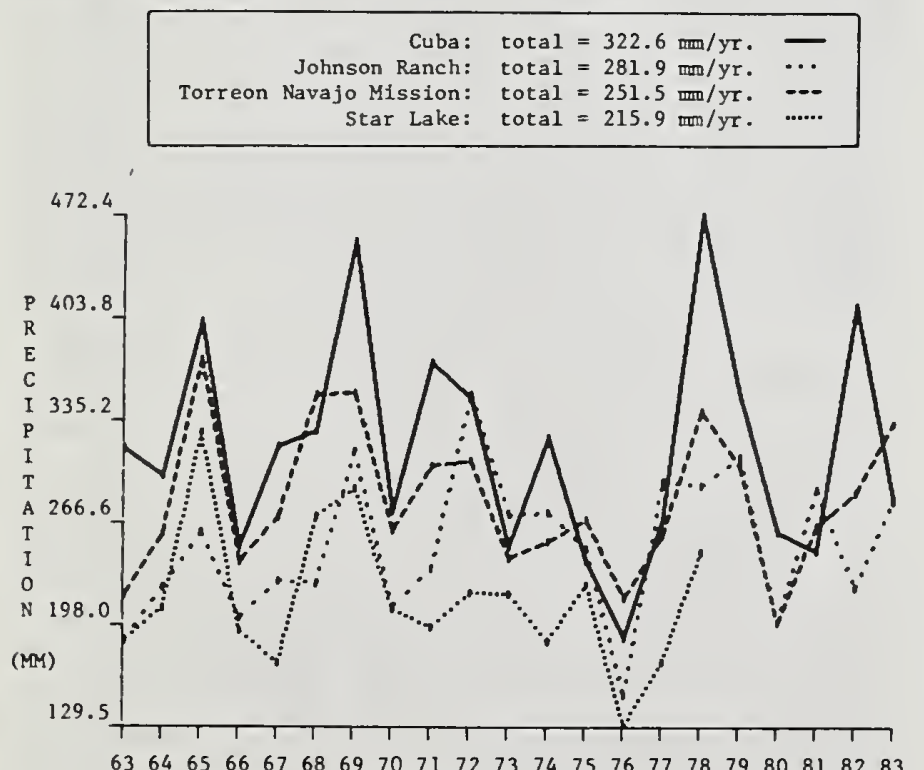

YEAR

Figure 2.-Yearly total precipitation for the Upper Rio Puerco Water. shed, 4 sites, 1963-1983. Mean total precipltation for each site Is shown in the key.
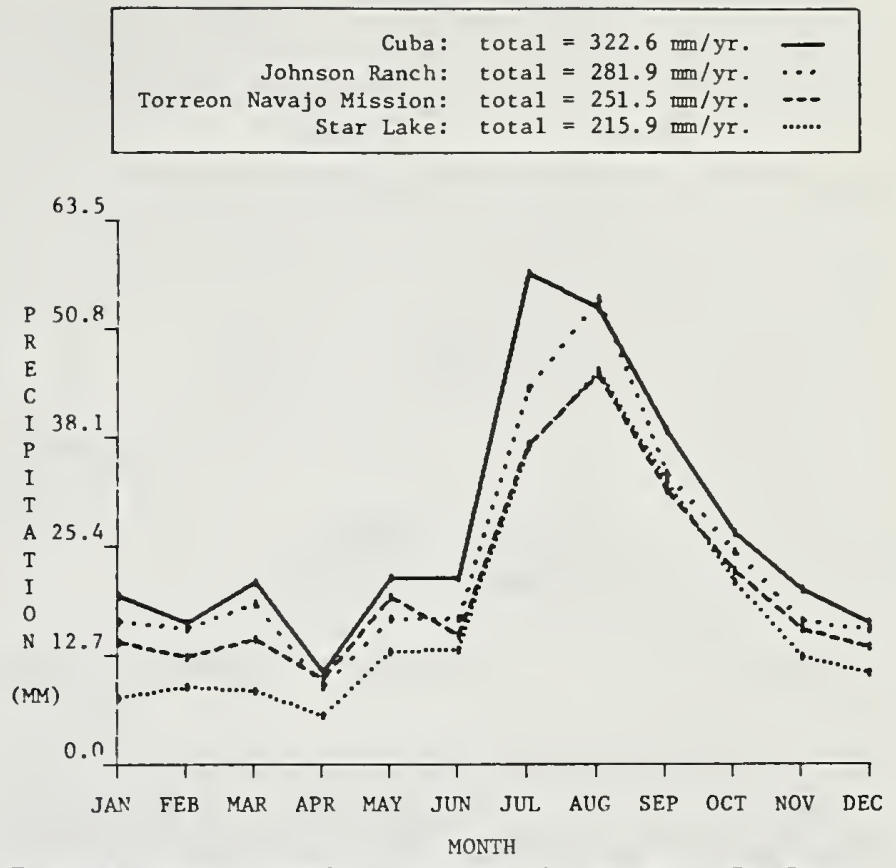

Figure 3.- Mean monthly precipitation for the Upper Rio Puerco Watershed, 4 sites, 1963-1983. Mean total precipitation for each site is shown in the key.

1. Mesas and ridge tops (uplands): Soils were residual; slopes, were less than $2 \%$.

2. Colluvial slopes: Areas usually of $10 \%$ slope or greater from which active or intermittent soil movement occurs, usually in nonaccelerated status; usually middle or upper slopes.

3. Lower colluvial slopes: Areas usually of $2-10 \%$ slope, where soil material (colluvium) from upper colluvial slopes is deposited above alluvial flats. Finer soil in suspension may pass through to alluvial flats or drainageways.

4. Alluvial flats: Areas of $0-2 \%$ slopes, where fine textured alluvium produced a characteristic landform with distinct topographic, soil, and vegetative boundaries.

5. Breaks: Rough, broken country with unstable soils, or areas where topography was too steep for normal soil development. Critical slope angle was undefined and varied with soil texture.

Soils data for the study area were compiled from the soil surveys of the Cabezon Area, New Mexico (Folks and Stone 1968) and the soil survey of Sandoval County, New Mexico ${ }^{5}$.

A preliminary reconnaissance of the study area indicated that 6 biomes and 13 vegetation series were present (Brown et al. 1979) (table 1). These biomes and their associated series were used as one of the classification element variables and the first level of stratification for sampling the study area.

The sampling procedure and site selection were based on homogeneous vegetation stands from which data were collected to quantify, identify, and classify the sites. The selection of stands was not based on lack of disturbance. The intent was to describe the existing vegetation of the study area so that present ecological stage and potential natural vegetation could be determined, and 
Table 1.-Biome and series level vegetation classification for the Upper Rio Puerco Watershed. (Brown et al. 1979).

\begin{tabular}{ll}
\hline \multicolumn{1}{c}{ Biome } & \multicolumn{1}{c}{ Series } \\
\hline Rocky Mountain Montane Conifer Forest & Pinus (Pinus spp.) \\
Great Basin Conifer Woodland & $\begin{array}{l}\text { Pinyon-Juniper (Pinus edulis- } \\
\text { Juniperus monosperma) } \\
\text { Plains Grassland }\end{array}$ \\
Great Basin Shrub-Grassland & Ricegrass (Oryzopsis spp.) \\
& Sacaton (Sporobolus spp.) \\
Semi-Desert Grassland & Galleta (Hilaria spp.) \\
Great Basin Desert-Scrub & Grama-Scrub (Bouteloua spp.-scrub) \\
& Sagebrush (Artemisia spp.) \\
& Rabbitbrush (Chrysothamnus spp.) \\
& Winterfat (Eurotia spp.) \\
& Saltbush (Atriplex spp.) \\
& Greasewood (Sarcobatus spp.) \\
& Mixed Shrub (Frankenia spp.)
\end{tabular}

to facilitate quantification and description of the existing vegetation communities for trend monitoring, application of management prescriptions, and ecological stage identification.

\section{SITE MEASUREMENTS}

The selection of sample sites was objective in order to minimize ecotones and site confounding, and to maximize homogeneity. A total of 114 sample sites were selected (fig. 4) where apparent changes in floristic

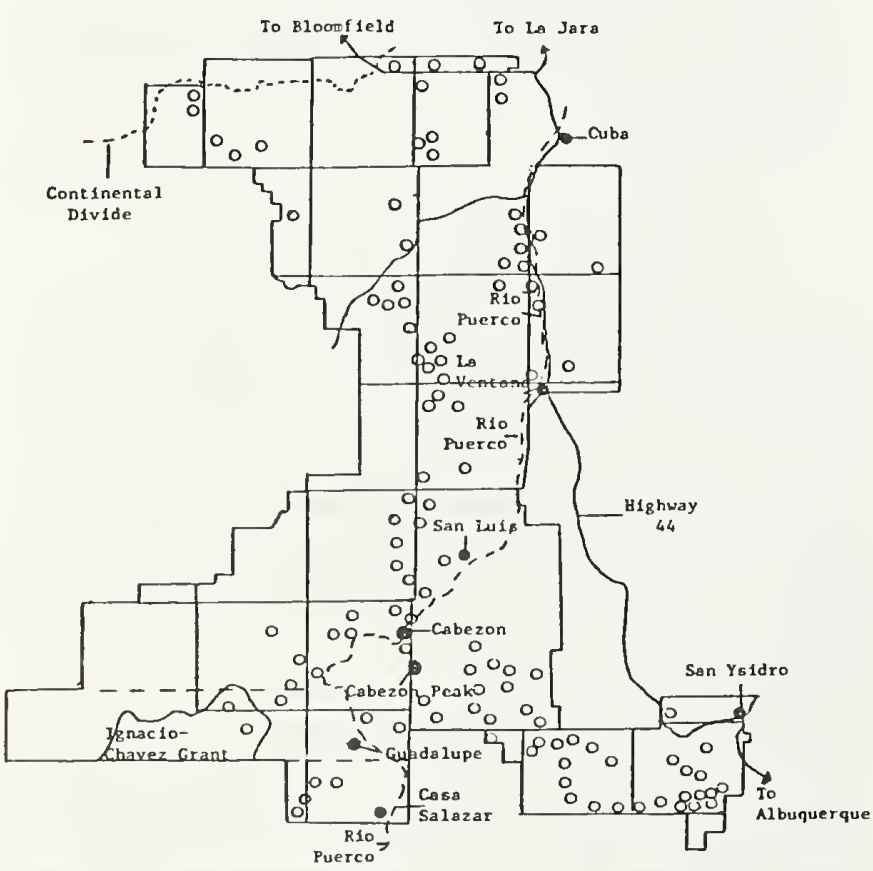

Figure 4.-Sample site locations (0) within the Upper Rio Puerco Watershed. aspect or plant composition, landform, and/or soils suggested a possible change in ecological sites. Transects were randomly established within each sample site. The number of transects per site varied from two to five, depending upon the apparent diversity and size of the site.

The Community Structure Analysis (CSA) technique (Pase 1981) was used to determine plant species foliar cover, density, and frequency defined respectively as the area of the ground surface covered by above-ground plant parts projected to the ground surface, the number of plants per unit area, and the number of plots in which a species occurred expressed as percentage of the total (Greig-Smith 1983). Transects consisted of one hundred $5 \mathrm{~cm}$ by $10 \mathrm{~cm}$ microplots (Morris 1973) for foliar cover, and ten $0.5 \mathrm{~m}^{2}$ circular plots for density and frequency. The microplots were systematically located every $2 \mathrm{~m}$ on a pace interval, and the circular plots were located at each tenth microplot. For each microplot, plant foliar cover by species was estimated using the following classes: $\mathrm{t}($ trace $)=0-5 \%, 1=6-15 \%, 2=16-25 \%, 3=$ $26-35 \%, 4=36-45 \%, 5=46-55 \%, 6=56-65 \%, 7=$ $66-75 \%, 8=76-85 \%, 9=86-95 \%$, and $10=96-100 \%$; analysis was based on class mid-points. In addition, plant litter, bare soil, and rock fragments larger than 1-inch diameter were estimated according to the same cover classes. Litter was defined as loose plant debris, or standing dead material for grass not of the current year's growth. Synusae (life-form strata) were evaluated separately. Frequency for each species was calculated using data from the $0.5 \mathrm{~m}^{2}$ plots; possible frequency ranged from $0-100 \%$ in $10 \%$ increments. Voucher specimens were collected and verified; ${ }^{7}$ not all fragmented plants could be identified.

${ }^{7}$ Voucher specimens were verified by Dr. Charles Feddema (USDA Forest Service Herbarium, Rocky Mountain Station, Fort Colins, Colo.) or Reggie Fletcher (Regional Botanist, USDA Forest Service, Southwestern Region, Albuquerque, N. Mex.). 


\section{DATA ANALYSIS}

Site data were analyzed and summarized using program $\operatorname{COSAM}^{8}$, which provided a summary of plant species with associated cover, density, and frequency values; the percent cover of bare soil, litter, rock; a ranked and arrayed importance value (IV) for each species; and a diversity index (DI).

Cover (C), density (D), and frequency (F) were considered to be three significant structural components of a community, and were used to calculate an importance value (Phillips 1959, Dix 1961) for each species by transect and site. These three variables represent an estimate of area, number, and distribution, respectively. Use of a single variable to describe community structure could result in over or underestimating an individual species contribution to the community (Dix 1961, Daubenmire 1968). This is especially true when dealing with a large number of species with widely contrasting structural characteristics and biological requirements. Therefore, an importance value for each species in each site was calculated to evaluate its contribution to and "importance" in the community. An importance value implies a species relative structural dominance and competitive status within a community, not the species value as forage or other use connotation. The value was based on equal weight of the relative foliar cover (percent), relative density (plants per $0.5 \mathrm{~m}^{2}$ ), and relative frequency (presence/absence of a species within a sample site). There is some question about the validity of giving these three plant community structural components equal value (Daubenmire 1968), and using relative rather than absolute values (MuellerDombois and Ellenberg 1974). Preliminary studies (Pase 1981) suggested three advantages of the present procedure: (1) IV was based on relative rather than absolute values; therefore, it was less affected by estimator bias; (2) the relative position of a plant in the community array was less disturbed by year-to-year differences in precipitation, because climatic variations affected all species to some magnitude; and (3) displacement of an IV within an array resulted from some differential ecological pressure against a species, such as differential grazing pressure or insect and/or disease perturbation, and is an unbiased estimator of changes in the plant community, or range condition (ecological stage).

The importance values were calculated using:

$$
I V_{i}=\frac{C_{i}}{\Sigma C}+\frac{D_{i}}{\Sigma D}+\frac{F_{i}}{\Sigma F}
$$

where: $I_{i}=$ importance value of the $i^{\text {th }}$ species;

$C_{i}, D_{i}, F_{i}=$ mean cover, density, frequency of the $\mathrm{i}^{\text {th }}$ species; and

$\Sigma C, \Sigma D, \Sigma F=$ the total cover, density, frequency for all sample species.

Importance values were summarized and averaged by species and by site.

\footnotetext{
${ }^{8}$ Program COSAM (Community Sample) was developed by and is on file at the USDA Forest Service, Rocky Mountain Station, Fort Collins, Colo.
}

The diversity indices (DI) of the sites were calculated based upon absolute density using the formula of MacArthur and MacArthur (1961):

$$
D I=\underset{i=1}{-s} P_{i} \log _{e} P_{i}
$$

where: $P_{i}=$ density of species $i$ as a proportion of total density for a site, and

$s=$ total number of species in the site, or species richness (SR).

This index is essentially the same as the Shannon-Weiner index:

$$
\mathrm{H}^{1}=\underset{\mathrm{i}=1}{-\mathrm{s}} \mathrm{P}_{\mathrm{i}} \log \mathrm{P}_{\mathrm{i}} \text { (Pielou 1975); }
$$

both are referred to as information theory indices (Peet 1974).

The mean importance values for each site from program $\operatorname{COSAM}^{8}$ were used to calculate resemblance coefficients and to develop resemblance matrices. The resemblance matrix consisted of dissimilarity coefficients derived from Euclidean distance coefficients (Sneath and Sokal 1973, Romesburg 1984). Euclidean distance coefficients were calculated using:

$$
e_{i k}=\left[\sum_{i=1}^{n}\left(x_{i j}-x_{i k}\right)^{2}\right]^{1 / 2}
$$

where

$\mathrm{e}_{\mathrm{jk}}=$ Euclidean distance between site $\mathrm{j}$ and site $\mathrm{k}$;

$\mathrm{x}_{\mathrm{ij}}=$ variable value for species $\mathrm{i}$ in site $\mathrm{j}$;

$\mathrm{x}_{\mathrm{ik}}=$ variable value for species $\mathrm{i}$ in site $\mathrm{k}$; and

$\mathrm{n}=$ number of species.

The dissimilarity coefficient, $e_{j k}$, can be no smaller than 0.0 , the value when sites $j$ and $k$ are maximally similar (identical). The larger the $e_{i k}$ value, the more dissimilar are the sites.

A dendrogram was produced using the resemblance matrix and a clustering method from program CLUSTAN (Cluster Analysis) (Wishart 1981). The clustering method used was developed by Ward (1963) and is based on the minimum variance between two sites (Romesburg 1984). The cluster routine followed a hierarchical-agglomerative-polythetic approach (Goodall 1978, Romesburg 1984). The dendrogram was developed using the vegetation variables of non-standardized IV data. To develop meaningful and realistic clusters, an IV $\geqq 0.1$ was used which appeared to include species which dominated the sites.

Resultant dendrograms were evaluated for realistic clusters using successive approximation (Poore 1962) and original site data summaries. Clusters were evaluated as to their separation of lifeform (tree, shrub, grass) and grouping of dominant species by site. Inter-cluster versus intra-cluster variability based on Euclidean distance was compared (Dyer 1978) as an index to significant clusters. 


\section{RESULTS AND DISCUSSION}

\section{LANDFORM}

The 114 sites sampled and classified were on five landform classes (table 2). Most grassland and shrubland sites were on alluvial flats, while the treeland sites generally were on mesas and colluvial slopes at higher elevations.

\section{SOILS}

Three soil orders, 27 soil series, 9 associations, and 3 complexes were identified within the study area (table 3 ). The three mapped units classified as complexes were identified to the suborder level, and one unit was identified as an azonal alluvial unit. Modal profile diagrams are in Appendix A.

\section{Entisols}

Fifteen soil series mapped singly and/or mapped into four soil associations were in the Entisol soil order. The Travessilla, Shingle, and Persayo soil series were mapped into two associations with depths of the A- and C-horizons of less than $50 \mathrm{~cm}$ and textures in the sandyloam to silty-clay loam class (Appendix A). Of the remaining 12 series within the Entisol order, 7 were mapped singly; 5 series were mapped into 3 associations (Appen$\operatorname{dix} \mathrm{A}$ ). These 12 series had depths of at least $152 \mathrm{~cm}$, contained an A1- and several C-horizons; surface textures ranged from silty-clay-loam, loamy-sand, clay-loam, and clay.

Most of the series within the Entisol order had a $\mathrm{pH}$ range of 8.0 to 8.8 , were mesic, calcareous, ustic, hot- dry (Torri), and had a mixed minerology. Three of the series were unnamed.

Several factors seem to limit soil development. These factors are mass soil movement and other erosion forms which remove surficial material from the sites as fast as or faster than most pedogenic horizons can form (Buol et al. 1973). Solifluction or creep also may be operating on slopes as low as $2 \%$. Most of the Entisols were on alluvial floodplains and probably were subject to cumulization, which may add new surface material as fast or faster than it can be assimilated into a pedogenic horizon. Lack of vegetation favors erosion and downslope deposition. A number of the series have been formed in sandstone and shale parent materials influenced by inert siliceous sediments inhibiting profile differentiation. Low fertility for plant growth of some initial materials limits biogenetic differentiation of the soil profile. Campbell (1968) confirmed low inherent soil fertility and sparse organic matter content. Lack of time may be another factor limiting soil formation and profile development. Given the total effective environment of the study area and region, these soils may be in equilibrium with their environment and associated vegetation, and may represent the edaphic "climax" of the region (Whittaker et al. 1968).

\section{Aridisols}

The Aridisol soil order was represented by 10 mapped series, all but one of which was mapped into 5 associations (table 3). One of the associations (A4) was mixed between Aridisol and Entisol (Appendix A); two of the series were unnamed. Most of the series were fineloamy texture, mixed mineralogy, mesic, ustollic, and calcareous.

Table 2.- Distribution (*) of vegetation formation and series by landform class and related number of soil series and sample sites for the Upper Rio Puerco Watershed.

\begin{tabular}{|c|c|c|c|c|c|c|}
\hline \multirow{2}{*}{$\begin{array}{l}\text { Plant community } \\
\text { classification }\end{array}$} & \multicolumn{4}{|c|}{ Landform Class } & \multirow{2}{*}{$\begin{array}{l}\text { Number } \\
\text { of soil } \\
\text { series }\end{array}$} & \multirow{2}{*}{$\begin{array}{l}\text { Number } \\
\text { of sites }\end{array}$} \\
\hline & & ${ }_{1}$ & Alluvial & Breaks & & \\
\hline \multicolumn{7}{|l|}{ Treeland } \\
\hline Pipo-Pied & * & * & & & 6 & 7 \\
\hline Jumo & $\star$ & * & & * & 8 & 9 \\
\hline \multicolumn{7}{|l|}{ Shrubland } \\
\hline Artr & * & * & * & & 19 & 24 \\
\hline CHRY & & & $\star$ & & 5 & 5 \\
\hline Save & & & * & & 3 & 3 \\
\hline Cela & * & * & * & & 9 & 10 \\
\hline Atcu & & * & & & 1 & 1 \\
\hline Atob & & & & & 3 & 4 \\
\hline Arno & & * & * & * & 2 & 2 \\
\hline Atca & & & * & & 6 & 7 \\
\hline \multicolumn{7}{|l|}{ Grassland } \\
\hline Bogr & * & * & * & & 9 & 12 \\
\hline $\mathrm{Hija}$ & & * & * & & 11 & 12 \\
\hline Spai & * & & * & & 13 & 14 \\
\hline Boer & * & & & & 2 & 2 \\
\hline Spne & * & & & & 1 & 1 \\
\hline Scbr & & & $\star$ & & 1 & 1 \\
\hline
\end{tabular}

\footnotetext{
${ }^{1}$ The two colluvial slope classes $(\geqslant 10 \%$, and $<10 \%)$ have been combined in this column.
} 
Table 3.- Soil classification and associated plant communities in the Entisol, Aridisol, and Mollisol soil orders and Complexes for the Upper Rio Puerco Watershed.

\begin{tabular}{|c|c|c|c|c|}
\hline Subgroup & Family & Series & Association & $\begin{array}{l}\text { Plant } \\
\text { Community \# }\end{array}$ \\
\hline \multicolumn{5}{|c|}{ Entisols } \\
\hline Ustic Torriorthent & loamy, mixed, calcareous, mesic & Shingle & A1 & $1,2,6,21,22,23,26,41$ \\
\hline Lithic Torriorthent & loamy, mixed, calcareous, mesic & Travessilla & $A 2$ & $14,22,32,34,35$ \\
\hline Typic Torriorthent & loamy, mixed, calcareous, mesic, shallow & Persayo & ] & \\
\hline
\end{tabular}

Ustic Torriorthent

fine, mixed, calcareous, mesic

fine, mixed, calcareous, mesic

Galisteo

Ustic Torriorthent

Ustic Torriorthent

fine-loamy, mixed, calcareous, mesic

Unnamed 2

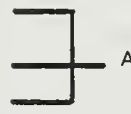

313,27

Ustic Torripsament

mixed mesic

Ustic Torrifluvent

Typic Torripsament

fine, mixed, calcareous, mesic

Unnamed $2 B$

Sheppard Variant

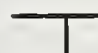

A9 $7,28,30,36,39$

sandy, mixed, nonacid, mesic

Unnamed 13

Berent

9,17

Typic Torrifluvent

fine-silty, mixed, calcareous, mesic

Billings

$21,29,31,32,35,38,39$

Typic Torrifluvent

fine, mixed, calcareous, mesic

Christainburg

$11,13,15,19,20,24,29$ $36,39,40,42$

Typic Torrifluvent

coarse-loamy, mixed, calcareous, mesic

Fruitland

$11,13,17,39,40$

Typic Torrifluvent

fine-silty, mixed, calcareous, mesic

Ravola

18,39

Ustic Torriorthent

fine-loamy, mixed, calcareous, mesic

Kim

$29,36,43,45$

Typic Torriorthent

fine, mixed, calcareous, mesic

Navajo

19

Ustollic Camborthid

Ustollic Camborthid

Ustollic Camborthid

Ustollic Camborthid

Ustollic Haplargid

Mollic Haplargid

Lithic, Ustollic Haplargid

Mollic Camborthid

\section{Aridisols}

fine-loamy, mixed, mesic

fine-loamy, mixed, mesic

fine-silty, mixed, mesic

fine-loamy, mixed, mesic

fine-loamy, mixed, mesic

fine-loamy, mixed, mesic

loamy, mixed, mesic

fine, mixed, mesic

fine-loamy, mixed, mesic

fine, mixed, calcareous, mesic

\section{Mollisols}

Lithic Arguistoll

clayey, montmorillonitic, mesic

fine-loamy, mixed, mesic

Entic Halustoll

Basalt OutcropsOrthents-Ustolls

\section{Complexes}

\section{Rock Outcrops}

Orthents

\section{Rock Outcrops}

Gypsum

Cabezon

$1,7,35$

Atrac

Unnamed 4

Las Lucas

Unnamed 78

A6 $9,16,21,22$

$25,32,35,36,37,40$

Hagerman

A7 31

Penistaja

A8 $3,8,9,13,32,35$

Bond

Little

36

Poleo

A4 $9,10,11,12,13$

Unnamed 2

(Entisol)

Prewitt

10 
The Bond and Unnamed-04 series were the most shallow, with less than $38 \mathrm{~cm}$ of effective soil. All other Aridisols were between 76 and $152 \mathrm{~cm}$ deep, with most greater than $102 \mathrm{~cm}$ (Appendix A). All series had an A1-horizon; series in association A5 had an A2-horizon; and all but Poleo and Bond had a B3ca-horizon. All but the Atrac series had an A1-horizon $\mathrm{pH}$ of 8.2; and all but the Hagerman series had one or more C-horizons.

Aridisols are associated with semi-arid climates and vegetation, and commonly have Entisols as inclusions (Buol et al. 1973). Also, the areas of Aridisol development are associated with Mollisols in surrounding cooler and/or wetter areas. This pattern fit the study area; most of the soils were Entisols with Aridisol associates and Mollisols at higher elevation sites which were cooler and more moist.

Leaching evidence often is seen in Aridisols; but this may be a result of rainfall extremes rather than means. The Aridisol environment is characterized by sparse plant growth, low surface soil organic matter, and low carbon/nitrogen ratios (Soil Survey Staff 1975). The soils inherit much of their morphology from the parent material and the lack of leaching has left the profiles with a high base status (Buol et al. 1973). Profiles are well oxidized; and profiles on the older, more stable landforms have accumulated clay to form argillic horizons as have three of the study area series with B2t-horizons (Appen$\operatorname{dix}$ A). Five of the series were Camborthids, and the other four were Haplargids (table 3 ).

\section{Mollisols}

Two of the 27 soils series were in the Mollisol soil order (table 3). The Prewitt series supported only one plant community, and was classified as a fine-loamy, mixed, mesic, entic Haplustoll. The soil depth exceeded $127 \mathrm{~cm}$ and had an A1-horizon $\mathrm{pH}$ of 8.0; all horizons were loamy (Appendix A).

The second Mollisol series, Cabezon, was shallow with an effective soil depth of less than $50 \mathrm{~cm}$ (Appendix A). The A1-surface horizon and B2t-horizon both had $\mathrm{pH}$ values of 7.0. The Cabezon series supported three plant communities and was classified as a clayey, montmorillonitic, mesic, lithic Argiustoll (table 3).

The two Mollisols in the study area were relatively young, because the clay content in the A-horizon was nearly equal to the clay content of the lower horizons, especially the B2t-horizon. The Prewitt series had no Bhorizon. Eluviation, illuviation, and percolation are probably acting minimally on these soils because of the overall low precipitation of the study area and region.

\section{Complexes}

Three relatively shallow complexes were identified and mapped in the study area (table 3). Two of the complexes were classified to the suborder level: Orthents and Ustolls, both associated with rock outcrops. Maximum depth of the soils in the complexes was about $50 \mathrm{~cm}$ (Appendix A). The general texture of soils found in complex
1 and 2 was silty-clay-loam. The third complex was a combination of rock outcrops and gypsum. The three complexes supported 10 different plant communities from each of the three vegetation formations.

\section{Alluvial}

An azonal, stratified mapping unit that was identified and classified as Alluvial land was deep, light colored, and nearly level or gently sloping (Folks and Stone 1968). It occurred on alluvial fans and flood plains throughout the study area. The surface layer was about $25 \mathrm{~cm}$ thick, very pale brown, contained free lime, and had a granular structure with texture ranging from loamy-fine-sand to loam (Appendix A). The subsoil was structureless and more compact than the surface layer. The subsoils consisted of stratified loam, sandy-loam, and clay loam derived from alkaline shale and sandstone deposited by streams. Alluvial land is well drained, permeability is moderate to slow, organic matter is low, and gully erosion is high. Alluvial land supported four plant communities; no community was unique to the map unit (table 3).

Results indicated that most plant communities occurred on more than one soil mapping unit and that most soil mapping units supported more than one plant community. There was no apparent qualitative correlation between plant communities and soil map units on the study area; no quantitative correlation was attempted.

\section{VEGETATION}

It was hypothesized that using species IV and Ward's clustering method would produce a dendrogram representing distinct site clusters of realistic plant communities and that an IV $\geqq 0.1$ would yield precise clusters using fewer species and, therefore, not confounding the $\mathrm{E}$ values used in Ward's method. By limiting the IV's to $\geqq 0.1$, it was speculated that only the most dominant species and lifeforms within each site would determine the fusion points.

The advantage of cluster analysis makes classification possible, even if it is arbitrary (Barbour et al. 1980). Although cluster analysis may be subjective, it quantifies the classification process because some threshold value may be chosen as the lower limit to an association or community. Cluster analysis still requires that the investigator evaluate the process and the results (Everitt 1979) using a non-abstract situation.

The 114 sites clustered using the criteria of species IV $\geqq 0.1$ resulted in 45 plant communities (p.c.) in 3 formations. The 45 plant communities were representative of 11 vegetation series consisting of 2 treeland, 5 shrubland, and 4 grassland formations (table 4). Intracluster variation among sites was significant for $82 \%$ of the communities tested, and inter-cluster variation among communities was significant for $73 \%$ of the series tested. Therefore, the majority of sites and communities were considered statistically and ecologically different as classified. 
Table 4.-Plant community classification, community number and name, and number of sample sites for the Upper Rio Puerco Watershed.

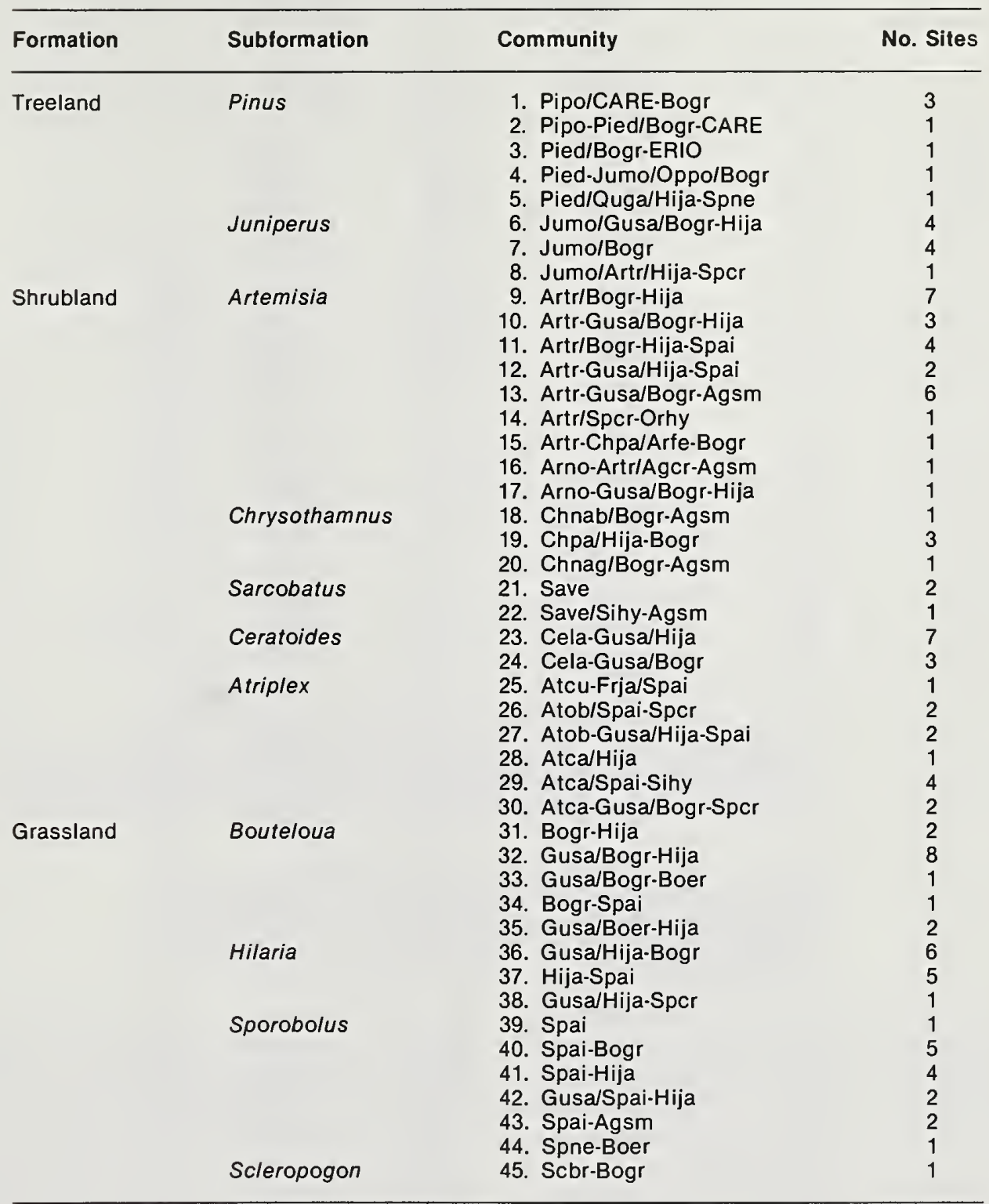

Initially, the plant communities were determined by setting the dendrogram dissimilarity index level (Euclidean distance) at approximately 0.565 (fig. 5). However, this dissimilarity level produced communities, in some cases, which were confounded by unlike species and lifeform. Therefore, an ordered printout of site summaries (table 5) which followed the horizontal dendrogram axis listing of sites was used to determine realistic clusters and species dominance. The sites were combined into communities based on species IV $\geqq 0.1$, if an individual species IV rank and lifeform dominated the site. For example, the first cluster formed at index 0.565 consisted of 10 sites: $1,141,152,37,136,142,140$, 144,143 , and 145 (fig. 5). Selecting the species by lifeform with the greatest IV from each site led to all of the sites within the same formation-shrubland. Sites 1 and 152 were classified as Artr (Artemisia tridentata)-Gusa
(Gutierrezia sarothrae)/Bogr (Bouteloua gracilis)-Hija (Hilaria jamesii) (p.c. 10) (table 5); site 141 was combined with sites 142,140,144,143, and 145 and classified as Artr-Gusa/Bogr-Agsm (Agropyron smithii) (p.c. 13) (table 5); sites 37, 5, 146, 7, 9, 23, and 22 classified as Artr/BogrHija (p.c. 9) (fig. 5, table 5). Note that sites 5, 146, 7, and 9 formed a realistic cluster and that sites 37,23 , and 22 were clustered with other sites and had to be recombined using site summary data (table 5). For example, site 22 (p.c. 9) was clustered with site 19 (p.c. 32). Boyd (1984) also found that the interpretation and refinement of clusters was necessary for ecologically meaningful communities.

An example of a realistic cluster requiring no additional combining was the grouping of sites 103, 104, 106, and 108 (fig. 5) which were classified as Jumo (Juniperus monosperma)/Gusa/Bogr-Hija (p.c. 6). 


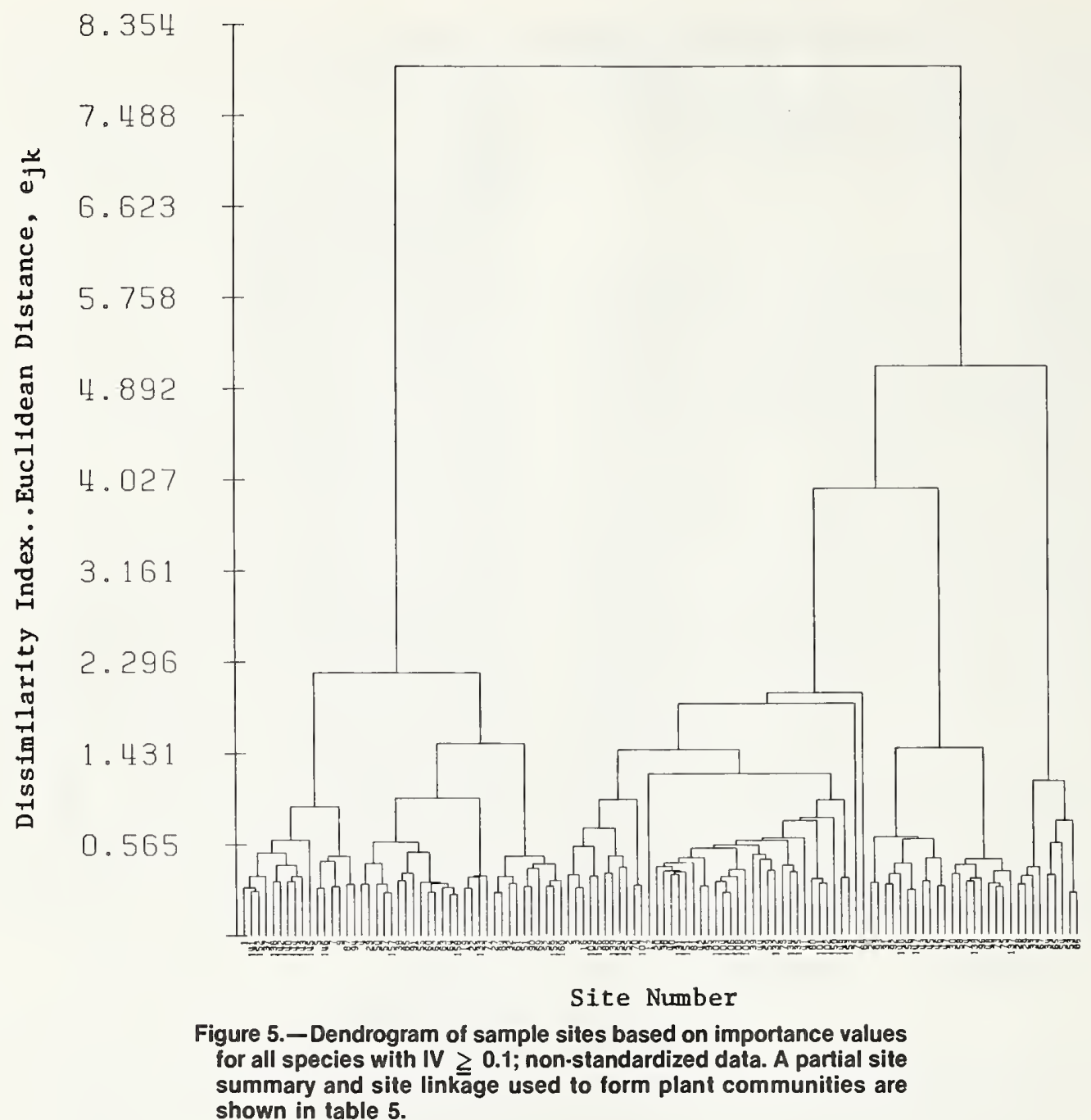

Therefore, inconsistent clusters which confounded lifeform and individual species required that each cluster of sites be examined using the dendrogram in relation to the site summaries. The result was 45 plant communities named for the dominant or co-dominant species by lifeform with an IV $\geqq 0.1$ (tables $6-50$ ).

The hypothesis that Ward's method and dissimilarity coefficients calculated from species IV $\geqq 0.1$ would provide distinct, realistic clusters was rejected based on the results of this study. However, the dendrogram and associated ranked site summary data provided a point of approximation for plant community descriptions.

In some cases, the classified plant communities were very similar and/or were developed from only one or two sites. For example, the Artemisia subformation (table 4) contained four communities with Bogr as the dominant grass species; but it was thought that the co-dominant species, Hija, Spai (Sporobolus airoides), and Agsm, occurred in sufficient amounts in different sites to warrant separation into different communities. Plant communities containing Gusa in significant amounts were separated because of the apparent lower ecological stage of the sites. Even though there have been conflicting reports as to the ecological status of Gusa-broom snakeweed (Jameson 1970, Ueckert 1979, McDaniel et al. 1982), indications are that snakeweed is a rapid invader and intense competitor in disturbed sites.

Plant communities consisting of only one or two sample sites were maintained as separate because of their unique floristics, management implications, or ecological status. For example, the Chrysothmnus subformation contained two communities of one site each (table 4); but the communities were composed of two subspecies which may respond differently to management, such as herbicide treatment, or may represent an edaphic or climatic microsite important for seeding or fertilizer application. Also, a community such as Spne (Sporobolus nealleyi)-Boer (p.c. 44) represented a unique edaphic situation in that Spne is specific to gypsum soil and Boer represented a plant community in a higher ecological stage. Another one-site example is the Scleropogon community (p.c. 45). This community was not widespread, but represented a potential natural vegetation association (Donart et al. 1978).

\section{PHYTO-EDAPHIC COMMUNITY DESCRIPTIONS}

The 45 plant communities based on plant species importance values (IV) $\geqq 0.1$ were classified and describ- 
Table 5. - Partial site summary of species variables following the horizontal dendrogram axissite number (fig. 5). Listed are five species with the highest IV $\geq 0.1$. Species in boldface were used to form and name the plant community (p.c.). Solid linēs connecting the sites indicate all of the sites used to form a p.c.; broken lines indicate some of the sites.

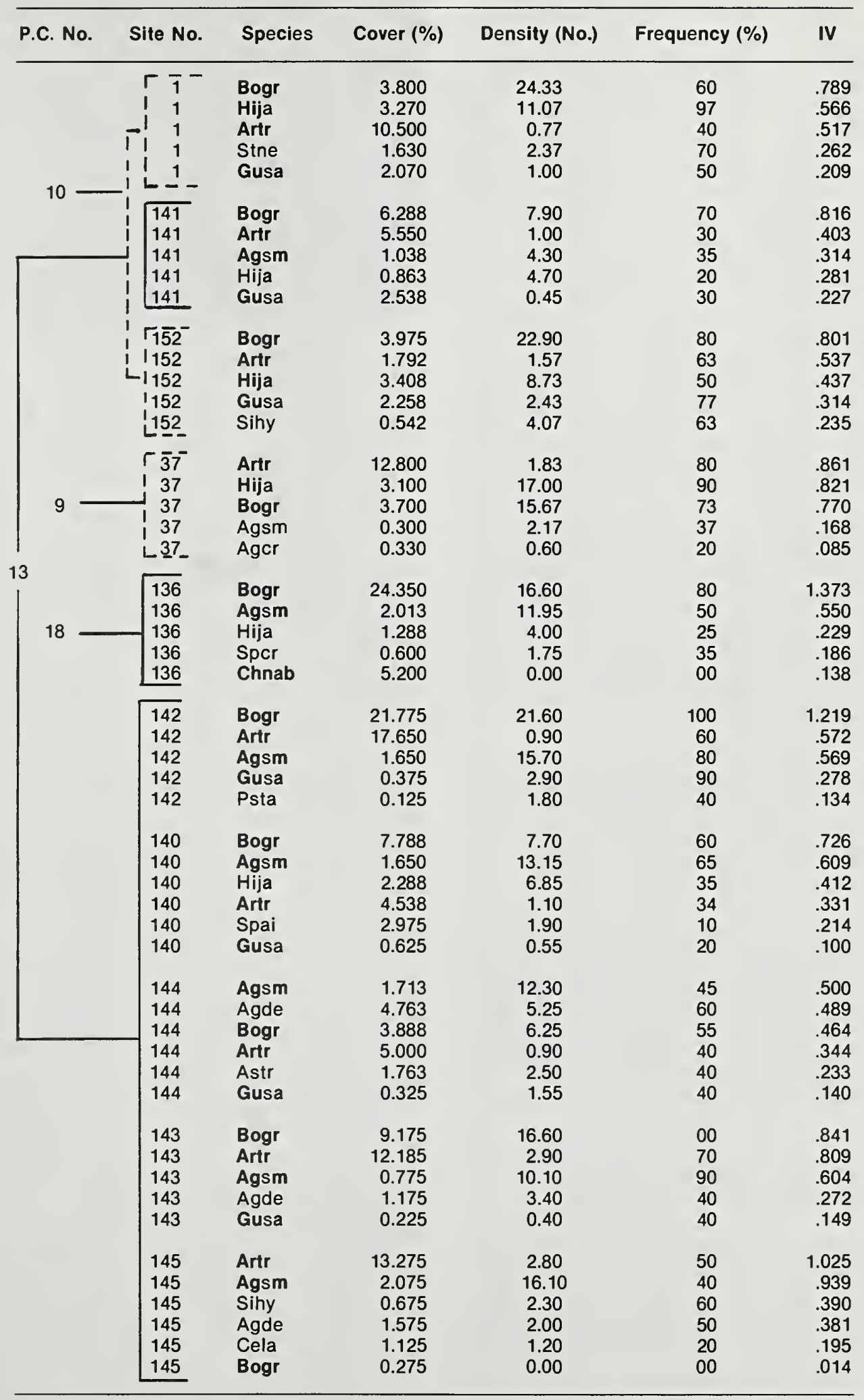


ed with their associated landform; soil series, association, or complex; ecological stage; and potential natural vegetation (PNV). The combined factors designated a phyto-edaphic community (Tiedeman and Terwilliger 1978). The classification followed a hierarchicalagglomerative-polythetic approach (Sneath and Sokal 1973, Pielou 1977) based on the ecological concepts of numeric classification (Goodall 1978, Romesburg 1984) and floristic-dominance types (Westhoff and van der Maarel 1978, Whittaker 1978) within stratal units (Barkman 1978). The vegetation of each community has been described in the existing vegetation context for identifiable units in the field. Ecological stage was based on quantitative community data, existing vegetation seral stage in relation to PNV, and soil-site degradation. PNV is hypothetical, stable, and based on existing vegetation projected into some undefined future, accounting for current site conditions and minimum human disturbance (Mueller-Dombois and Ellenberg 1974, Schlatterer 1978). PNV should not be confused with the original or pristine vegetation. Quantitative results and objective judgment indicated that most of the existing phytoedaphic communities were in a mid-to-high seral stage, but degraded.

Detailed soil profiles are in Appendix A. Species symbols, scientific names, authority, and common names are in Appendix B. The typal plant community vegetation and soil surface factor data are in tables 6-50. For some minor species, the mean or total for IV, cover, density, or frequency may be shown as zero (0.0) because of rounding or the number of digits carried (e.g., table 6). For some communities consisting of only one site, there are no range data (e.g., table 7).

A dichotomous key to the phyto-edaphic communities is presented in Appendix C. Each vegetation subformation includes a representative community photo. The plant community descriptions are grouped by formation, subformations, series, and communities within series; each plant community is numbered (p.c. 1-45).

The plant communities were named according to the dominant and/or co-dominant plant species within each lifeform synusia. Plant species were considered dominant or co-dominant if they had the greatest IV rank for their specific lifeform. Species were listed in the following order: tree/shrub/forb/grass or grasslike. Lifeforms were separated by a slash (/), co-dominants within a lifeform were separated by a dash (-).

\section{Treeland Formation...Pinus Subformation ...P. ponderosa, P. edulis Series}

The five communities classified within the Pinus subformation consisted of sites which had ponderosa pine (Pinus ponderosa) and/or pinyon pine (Pinus edulis) dominating the tree synusia with an IV $\geqq 0.1$ and at least one shrub, forb, grass, or grasslike as a dominant understory synusia (fig. 6). The series occurred on three soil orders and seven different soil series and/or associations. The Pinus subformation occurred on two landforms at the higher study area elevations, and the

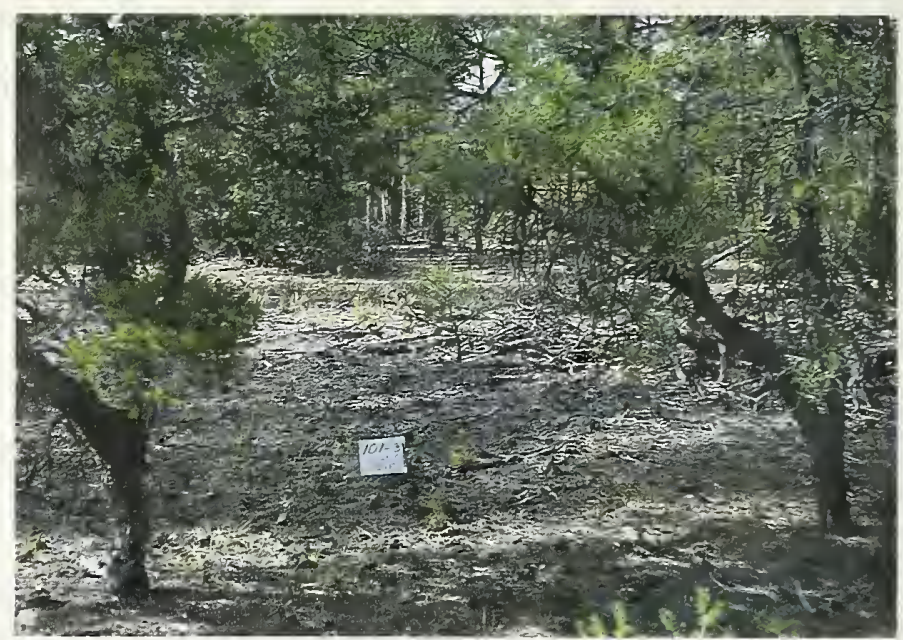

Figure 6.-Representative photo of the Pinus subformation. Pic. tured is the Pinus ponderosa/Carex spp. - Bouteloua gracilis plant community (p.c.1).

communities were not considered as major within the study area.

\section{Pinus ponderosa/Carex spp.-Bouteloua gracilis p.c.}

(Pipo/CARE-Bogr; ponderosa pine/sedge-blue grama)

General: This community represented the most common treeland community within the study area. The community was represented by three sites between $2,286 \mathrm{~m}$ and $2,438 \mathrm{~m}$ in elevation.

Landform: Mesas and colluvial slopes.

Soils: Ustic/Lithic Torriorthent, Shingle-Travesilla series (Assoc.Al);

Lithic Argiustoll, Cabezon series (table 3).

In general, soils were shallow, loamy, well-drained, and formed from mixed colluvial and eolian material. A modal profile was less than $76 \mathrm{~cm}$ in depth, with an effective soil depth of less than $25 \mathrm{~cm}$ (Appendix A, figs. A1 and A7). Two of the three sites occurred on soil association A1. Bare soil and litter averaged $74.2 \%$ and $21.7 \%$, respectively (table 6 ).

Vegetation: Pipo contributed $21.7 \%$ and $62.5 \%$ of the total IV and cover of this community, respectively (table 6). Eight of the 34 species contributed nearly $80 \%$ or greater of the totals for IV, cover, density, and frequency at $I V \geqq 0.1$. Pied (Pinus edulis) and Quga (Quercus gambelii) occurred, but in minor amounts. Hyri (Hymenoxys richardsonii) ranked number 3 for IV and number 1 for frequency, but was not included as part of the community name. Pofe (Poa fendleriana) was a major component in two of the three sites.

Ecological Stage: Mid-seral.

PNV: Current vegetation with increased amounts of Bohi (Bouteloua hirsuta), Agsm (Agropyron smithii), Cemo (Cercocarpus montanus), Kocr (Koeleria cristata), and Pofe for a higher ecological stage.

\section{Pinus edulis - P. ponderosa/Bouteloua gracilis-Carex spp. p.c.}

(Pied-Pipo/Bogr-CARE; pinyon-ponderosa pine/blue grama-sedge) 
General: This community may be considered as a phase of p.c. 1, or possibly an ecotone between p.c.1 and p.c.4. However, the community was representative of a definite community structure dominance change from p.c.1 between Bogr-CARE and Pipo-Pied. The community occurred at an elevation of $2,181 \mathrm{~m}$.

Landform: Mesa.

Soils: Ustic/Lithic Torriorthent, Shingle-Travessilla series (Assoc.A1) (table 3).

Soils in this association were classified as Entisols and were calcareous, loamy, mixed, shallow, and welldrained. The effective soil depth was less than $50 \mathrm{~cm}$, and $\mathrm{pH}$ ranged between 8.0 and 8.2 (Appendix A, fig. A1). Bare soil and litter averaged $69.6 \%$ and $24.6 \%$, respectively (table 7).

Vegetation: Bogr contributed $25.8 \%$ and $51.2 \%$ of the total IV and density, respectively (table 7). Pied contributed $11.2 \%$ and $33.1 \%$ of the IV and cover, respectively. Of the 23 plants in this community, seven contributed greater than $75 \%$ to the variable totals at IV $\geqq 0.1$. Chvi2 (Chrysopsis vellosa) had an IV $=0.563$ and a frequency of $91 \%$, but was not included in the community name. Artr (Artemisia tridentata), Jumo (Juniperus monosperma), Kocr, and Quga were minor components. Ecological Stage: High-seral.

PNV: Current community with increased amounts of SPOR (Sporobolus spp.), Kocr, and Hija (Hilaria jamesii) for a higher sere. If Gusa (Gutierrezia sarothrae), Quga, or SENE (Senecio spp.) increase, the seral trend will be downward indicating a perturbation.

\section{Pinus edulis/Bouteloua gracilis - Eriogonum spp. p.c.}

(Pied/Bogr-ERIO; pinyon pine/blue grama-buckwheat)

General: This is a minor community, but very common on steep, rocky slopes at elevations from $1,524 \mathrm{~m}$ to $2,438 \mathrm{~m}$.

Landform: Steep, rocky colluvial slopes.

Soils: Mollic Haplargid, Penistaja-sandstone series (table 3).

This Aridisol soil had an effective depth of about $50 \mathrm{~cm}$ (Appendix A, fig. A6). It was well-drained, formed in mixed alluvium and eolian sediments, and was sandy to clay loam in texture with occasional sandstone outcrops. The surface rock of this community was greater than $20 \%$, and bare soil and litter averaged $70.0 \%$ and $1.6 \%$, respectively (table 8 ).

Vegetation: Buckwheat species accounted for nearly $50 \%$ of each of the vegetation variable totals (table 8). Bogr ranked number 2 for IV and density, and Pied ranked number 3 and 1 for IV and cover, respectively. The majority of ERIO species and Bogr occurred as evenly spaced components under Pied. Jumo, Gusa, Hija, and Orhy (Oryzopsis hymenoides) were minor components. Ecological Stage: Low-seral.

PNV: Current composition with increased Hija, Orhy, and MUHL (Muhlenbergia spp.) would yield a higher seral stage. Obtaining a higher sere may be unreasonable on steep, rocky slopes.

\section{Pinus edulis-Juniperus monosperma/Opuntia polyacantha/Bouteloua gracilis p.c.}

(Pied-Jumo/Oppo/Bogr; pinyon pine - one-seed juniper/prickly pear cactus/blue grama)

General: This community appears to be a minor, yet, important component within the study area because of composition, low diversity, and SR. Elevation of the study site was $2,225 \mathrm{~m}$.

Landform: Mesa.

Soils: Basalt Outcrops-Orthents-Ustolls (Complex C1) (table 3).

This map unit complex consisted of $30-50 \%$ basalt outcrops, $20-40 \%$ Orthents, and $20-40 \%$ Ustolls. Effective soil depth was $25 \mathrm{~cm}$ to $76 \mathrm{~cm}$ with variable textures, but usually stoney to clay loam (Appendix A, fig. A8). Mean values for litter, rock, and bare soil were $14.5 \%$, $2.2 \%$, and $77.4 \%$, respectively (table 9 ).

Vegetation: Bogr accounted for $45.7 \%$ and $75.1 \%$ of the total IV and density components, respectively (table 9). Ranked second for IV, density, and frequency was Oppo, indicating a degraded, xeric community. Pied accounted for about $20 \%$ of the total cover and Jumo accounted for about $30 \%$ of the total cover; only three grass species occurred in the sample community. Six of the 10 species accounted for $90 \%$ or greater of each variable total.

Ecological Stage: Low-mid seral.

PNV: Current community plus increased amounts of Hija and Sihy (Sitanion hystrix) for higher seral stage with Oppo and Gusa niches filled by grasses.

\section{Pinus edulis/Quercus gambelii/Hilaria jamesii- Sporobolus nealleyi p.c.}

(Pied/Quga/Hija-Spne; pinyon pine/gambel oak/galletagypgrass)

General: This is a minor community, sampled at low intensity, but unique and included because of its occurrence on gypsum soils. The sample site was at an elevation of $1,829 \mathrm{~m}$.

Landform: Mesas.

Soils: Rock outcrops-gypsum (Complex C3) (table 3).

Rock outcrops and gypsum land made up $30-50 \%$ of this complex, respectively. The complex occurred on steep ridges, bluffs, and breaks. The gypsum land usually occurred as nearly pure and weathered with unstable, erodible surfaces. The rock outcrops were sandstone, shale, hard gypsum (Appendix A, fig. A8). The Pied/ Quga/Hija-Spne community was unique to this soil. Bare soil averaged $95 \%$, litter $3.3 \%$, and surface rock $0 \%$ (table 10).

Vegetation: Hija and Spne were ranked number 1 and 2 , respectively for IV, density, and frequency (table 10). Quga and Pied were ranked number 1 and 2 for cover, respectively. Mean plant density was low (3.4), and 8 of the 13 species accounted for greater than $88 \%$ of the total IV, cover, and density values. Total herbaceous cover 
was only $1.7 \%$. The community was actually dominated by Hija with an overstory cover synusia dominated by Pied and Quga; similar to the pinyon-juniper-oak association (CW1a) of Donart (1978).

Ecological Stage: Mid-seral; somewhat degraded with the presence of Gusa.

PNV: Existing community with increased dominance of Spne and Orhy under effective management and decreased Gusa.

\section{Treeland Formation...Juniperus Subformation ...J. monosperma Series}

The three communities classified within the Juniperus subformation consisted of sites which had Jumo dominating the tree synusia with an IV $\geqq 0.1$ and at least one shrub, forb, grass or grasslike as a dominant understory synusia (fig. 7). The series occurred on three soil orders, two complexes, and three landforms. The series was not a major areal component of the study area.

\section{Juniperus monosperma/Gutierrezia sarothrae/Bou- teloua gracilis-Hilaria jamesii p.c.}

(Jumo/Gusa/Bogr-Hija; one-seed juniper/snakeweed/ blue grama-galleta)

General: This community occurred at elevations between $1,768 \mathrm{~m}$ and $2,012 \mathrm{~m}$ and was represented by four sites; it was indicative of degraded site conditions.

Landform: Breaks and colluvial slopes.

Soils: Ustic/Lithic Torriorthent, Shingle-Travessilla series (Assoc.Al);

Basalt outcrops-Orthents-Ustolls (Complex C1);

Rocky outcrops-Orthents (Complex C2) (table 3).

This community occurred on Entisols represented by two series (one association) and two complexes. These soils were generally shallow with an effective soil depth of less than $50 \mathrm{~cm}$ (Appendix A, figs. A1 and A8). Bare

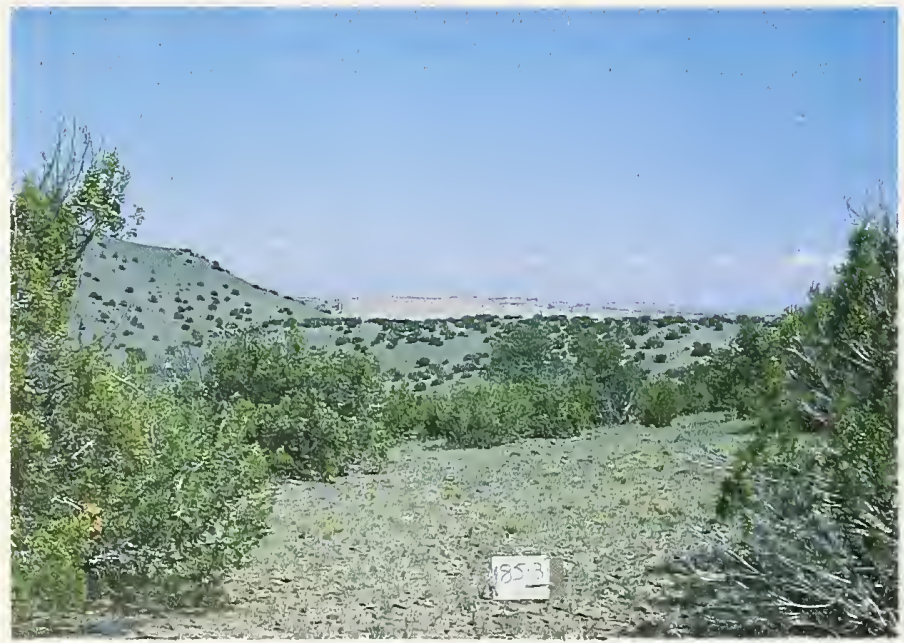

Figure 7.-Representative photo of the Juniperus subformation. Pic. tured is the Juniperus monosperma/Bouteloua gracilis piant community (p.c.7). soil and surface rock averaged $60.5 \%$ and $18.6 \%$, respectively (table 11). Textures were silty to clay loam, mineralogy was mixed, and most sites were calcareous. The community was not soil specific.

Vegetation: Bogr and Hija essentially shared the number 1 rank for IV, and frequency; but Bogr dominated cover and density for herbaceous species (table 11). Gusa was ranked third in IV, while Jumo dominated the cover values by contributing $19.2 \%$ of the total cover. Seven species represented greater than $65 \%$ of the total for each variable. This community primarily differs from p.c. 7 by the co-dominance of Bogr and Hija; Bogr dominated the IV in p.c. 7, and Jumo cover is about doubled. Gusa is approximately the same for all variables in both p.c. 6 and p.c. 7. Pied contributed only $0.9 \%$ and $2.8 \%$ of the total IV and cover, respectively.

Ecological Stage: Mid-seral.

PNV: Higher ecological stage by increasing Boer (Bouteloua eriopoda), Bocu (Bouteloua curtipendula), Spai (Sporobolus airoides), Sihy, Cemo, and Agsm; and by decreasing Gusa, Arlo (Aristida longiseta), and Hyri. Jumo will be a permanent community member.

\section{Juniperus monosperma/Bouteloua gracilis p.c.}

(Jumo/Bogr; one-seed juniper/blue grama)

General: This community is the typal of four sites and occurred at elevations between $1,798 \mathrm{~m}$ and $2,012 \mathrm{~m}$. It differs from p.c. 6 primarily in the dominance of Bogr and Jumo.

Landform: Breaks and colluvial slopes.

Soils: Ustic Torripsament/Torrifluvent, Sheppard-Unnamed 13 (Assoc. A9);

Lithic Argiustoll, Cabezon series;

Rock outcrops-Orthents-Ustolls (Complex C1) (table 3).

This community occurred on two soil orders, Entisol and Mollisol, represented by three series and one complex. The Entisol series were relatively deep, with effective depths of greater than $127 \mathrm{~cm}$ (Appendix A, figs. A3 and A8). Textures were loamy-sand and clay with mixed mineralogy; $\mathrm{pH}$ average about 8.6. The Mollisol series was shallow with an effective depth of $3.8 \mathrm{~cm}$, a pH of 7.0, and clayey texture (Appendix A, fig. A7). One site occurred on each of the soils. Bare soil equalled $74.0 \%$, rock $11.4 \%$, and litter $7.9 \%$ (table 12 ).

Vegetation: Bogr dominated the IV, density, and frequency variables with $35.3 \%, 65.0 \%$, and $24.7 \%$ of the totals, respectively (table 12). Jumo contributed $40.3 \%$ of the total cover. Five of 44 species contributed about $80 \%$ or greater of the total IV, cover, and density totals. This community differs from p.c. 6 in that Jumo cover was twice as large and Bogr was not co-dominant with Hija. Also, Gusa was more pronounced in p.c. 6 , and bare soil was about $15 \%$ less and rock was about $7 \%$ greater.

Ecological Stage: Mid-high seral.

PNV: Existing community with increased amounts of Spcr (Sporobolus cryptandrus), Boer, and Orhy for a higher ecological stage and decreased amounts of Gusa, 
Muto (Muhlenbergia torreyi), and infrequent species. Jumo is a persistent component, along with Pied in very minor amounts.

\section{Juniperus monosperma/Artemisia tridentata/Hilaria jamesii-Sporobolus cryptandrus p.c.}

(Jumo/Artr/Hija-Spcr; one-seed juniper/big sagebrush/ galleta-sand dropseed).

General: This community was not well sampled, but formed a unique floristic group common along break slopes or mesa tops. It occurred at an elevation of $2,012 \mathrm{~m}$ and differs from p.c. 6 and p.c. 7 by the codominance of Jumo and Artr.

Landform: Mesas.

Soils: Mollic/Lithic Haplargid, Penistaja-Bond series (Assoc. A8) (table 3).

The Aridisols in this soil association were relatively shallow with an effective depth of 38-76 cm; texture was fine-loamy with a $\mathrm{pH}$ of 8.2 (Appendix A, fig. A6). Bare soil, litter, and rock averaged $72.4 \%, 19.7 \%$, and $1.5 \%$, respectively (table 13).

Vegetation: Hija and Spcr essentially shared IV dominance contributing $29.0 \%$ and $24.7 \%$ of the total, respectively; Artr contributed $13 \%$ of the total (table 13). Also, Hija and Spcr dominated the density and frequency totals. Cover values were dominated by Artr contributing $31.9 \%$ of the total, followed by Hija and Jumo. Seven species represented greater than $90 \%$ of the IV, cover, and density total values. The community was somewhat degraded with Gusa occurring in 30\% of plots; and Agsm and Orhy were not well represented.

Ecological Stage: Mid-high-seral with degraded aspect. PNV: Existing community with increased amounts of Sihy, Agsm, Orhy, and Spai to obtain high seral stage. Artr and Jumo are permanent occupants.

\section{Shrubland Formation...Artemisia Subformation ...A. tridentata, $A$. nova Series}

Nine communities were classified within the Artemisia subformation which consisted of sites that had Artr or Arno (Artemisia nova) dominating the shrub synusia with an IV $\geqq 0.1$ and at least one forb, grass or grasslike as a dominant understory synusia (fig. 8). The series occurred on three soil orders, none of the complexes, and all landforms. The subformation was a major component of the study area.

\section{Artemisia tridentata/Bouteloua gracilis-Hilaria jamesii p.c.}

(Artr/Bogr-Hija; big sagebrush/blue grama-galleta)

General: This community occurred at elevations between $2,073 \mathrm{~m}$ and $2,195 \mathrm{~m}$ and was common within the study area occupying several soils.

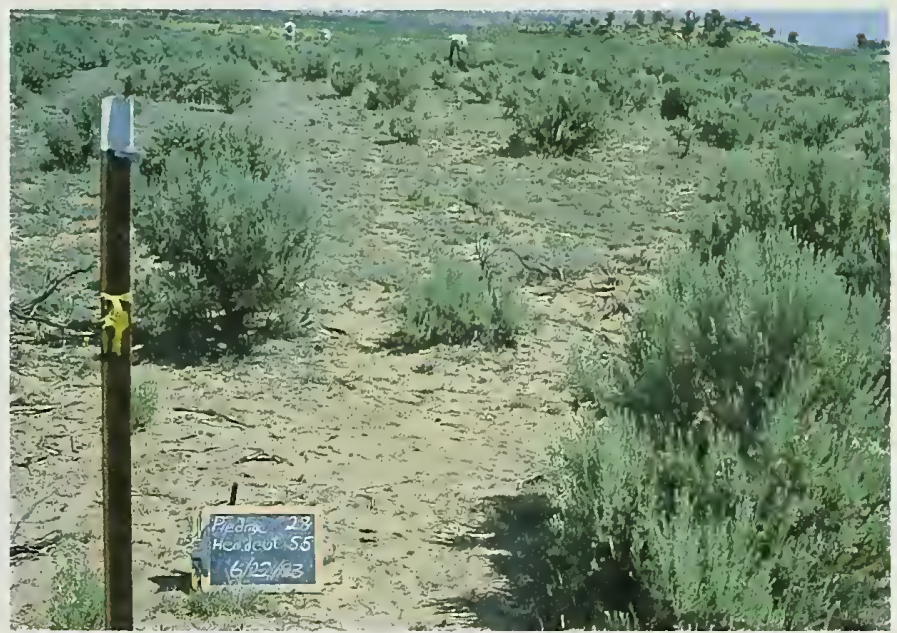

Figure 8.-Representative photo of the Artemisia subformation. Pictured is the Artemisia tridentata/Bouteloua gracilis-Hilaria jamesii plant community (p.c.9).

Landform: Mesas and alluvial flats.

Soils: Typic Torripsament, Berent series;

Ustollic Camborthid, Las Lucas-Unnamed 7B series (Assoc.A6);

Mollic/Lithic Haplargid, Penistaja-Bond series (Assoc. A8);

Ustic Haplargid/Torriorthent, Poleo-Unnamed 2 (Assoc. A4) (table 3).

This community occurred on one series and three associations within the Entisol and Aridisol orders; one of the associations (A4) was on Aridisol-Entisol mix. Textures ranged from sandy to fine-loamy with mixed minerology. Most of the soils were deep, with an effective soil depth greater than $152 \mathrm{~cm}$; the Bond series in Association A8 was shallow and probably did not support a site within the community (Appendix A, figs. A2, $\mathrm{A} 4, \mathrm{~A} 5$, and $\mathrm{A6}$ ). Bare soil and litter averaged $79.7 \%$ and $9.1 \%$, respectively (table 14 ).

Vegetation: Bogr dominated all variables with values of $47.1 \%, 43.0 \%, 76.0 \%$, and $27.1 \%$ of the total IV, cover, density, and frequency, respectively (table 14). Artr was ranked second for all variables except density, and Hija was ranked third for all variables except density for which it ranked second. Of the 23 species, 4 accounted for greater than $85 \%$ of the IV, cover, and density totals and therefore the low diversity index. Artr accounted for almost $50 \%$ of the total community cover. Spcr was a constant community member.

Ecological Stage: Mid-seral.

PNV: Existing plant composition with increased amounts of Agsm, Spai, and Cela (Ceratoides lanata) for a higher seral stage. Gusa will probably retain its spatial and functional niche, but in minor amounts under proper management.

\section{Artemisia tridentata-Gutierrezia sarothrae/Boutel- oua gracilis-Hilaria jamesii p.c.}

(Artr-Gusa/Bogr-Hija; big sagebrush-snakeweed/blue grama-galleta) 
General: This community is essentially the same as p.c. 9 , but degraded (fair condition) because of the status of snakeweed. Sample site elevations were between $2,103 \mathrm{~m}$ and $2,195 \mathrm{~m}$.

Landform: Mesas and alluvial flats.

Soils: Ustollic Camborthid, Atrac-Unnamed 4 series (Assoc. A5);

Ustollic Haplargid/Torriorthent, Poleo-Unnamed

2 series (Assoc. A4);

Entic Haplustoll, Prewitt series (table 3).

This community occurred on series within the Aridisol and Mollisol orders. Each site was on a different soil; all soils were fine-loamy textured, which accounted for the prevalence of Artr and Gusa. All of the soils exceeded a depth of $127 \mathrm{~cm}$, except for the Unnamed 4 series which probably did not support this community (Appen$\operatorname{dix}$ A, figs. A2, A5, and A7). Bare soil and litter was $77.8 \%$ and $10.5 \%$, respectively (table 15 ).

Vegetation: As with p.c. 9, Bogr ranked first for all variable accounting for $35.5 \%, 30.5 \%, 56.4 \%$, and $18.9 \%$ of the totals for IV, cover, density, and frequency, respectively (table 15). Hija ranked second, except for cover which was accounted for by Artr with $28.7 \%$ of the total. Gusa was ranked fourth in IV and cover, but occurred in nearly one-half of all plots with a frequency of $48.0 \%$. Therefore, this community was separated from p.c. 9. Six species accounted for greater than $85 \%$ of the totals for IV, cover, and density.

Ecological Stage: Mid-seral, but degraded.

PNV: Existing vegetation with increased amounts of Agsm, Orhy, Spai, and Cela; and decreased amounts of Gusa and Hija with proper management.

\section{Artemisia tridentata/Bouteloua gracilis-Hilaria jamesii-Sporobolus airoides p.c.}

(Artr/Bogr-Hija-Spai; big sagebrush/blue grama-galletaalkali sacaton)

General: This community had similar vegetation to p.c. 9 and p.c. 10, but with three dominant grass species and minor amounts of snakeweed. Site elevations were between 2,073 $\mathrm{m}$ and 2,164 $\mathrm{m}$. Also, soils were formed in alluvial deposits and differed from p.c. 9 and p.c. 10. Landform: Alluvial flats.

Soils: Typic Torrifluvent, Christainburg series;

Typic Torrifluvent, Fruitland series;

Ustic Haplargid/Torriorthent, Poleo-Unnamed 2 series (Assoc. A4) (table 3).

This big sagebrush community occurred only on Entisols which were fine to coarse-loamy and mixed. All of the soils were greater than $152 \mathrm{~cm}$ deep, with Ahorizons less than $25 \mathrm{~cm}$ (Appendix A, figs. A2 and A4). The Poleo series in Association A4 was an Aridisol, but probably did not support one of the sample sites. Bare soil was $81.8 \%$ and litter was $5.4 \%$ (table 16 ).

Vegetation: Bogr and Hija were ranked first and second, and contributed almost identical percentages to the total values of IV, cover, density, and frequency (table 16). Spai was ranked third, contributed approximately $18 \%$ to the four variable totals, and, therefore, was included in the community name. Artr was ranked fourth for IV, density, and frequency, and second for cover. The four species after which the community was named, accounted for $90 \%$ or more of the total IV, cover, and density values, and, therefore, the relatively low diversity index of 1.19 .

Ecological Stage: High-seral.

PNV: Current community plus increased amount of Agsm, Spai, and Orhy to maintain a high-seral stage with proper management. Gusa occurred in three sites, but in minor amounts.

\section{Artemisia tridentata-Gutierrezia sarothrae/Hilaria jamesii-Sporobolus airoides p.c.}

(Artr-Gusa/Hija-Spai; big sagebrush-snakeweed/galleta-alkali sacaton)

General: The community was similar to p.c. 11 but with a reversal in species dominance and somewhat degraded with an increase of snakeweed. The two sites within this community occurred at elevations of $2,103 \mathrm{~m}$ and $2,164 \mathrm{~m}$ on slopes.

Landform: Colluvial and alluvial slopes.

Soils: Ustollic Camborthid, Atrac-Unnamed 4 series (Assoc. A5);

Ustollic Haplargid/Torriorthent, Poleo-Unnamed 2 series (Assoc. A4) (table 3).

This community occurred on Aridisols which formed two associations consisting of four series. The Poleo series in Association A4 is an Entisol, and probably did not support a sample site. All series except Unnamed 4 were deeper than $152 \mathrm{~cm}$ and had shallow A-horizons and B-horizons of about $51 \mathrm{~cm}$ in depth (Appendix A, figs. A2 and A5). Textures were fine-loamy and mixed. Litter was only $5.9 \%$ and bare soil averaged $85.7 \%$ (table 17), which probably accounted for the increased amount of Gusa along with eroded slopes of up to $10 \%$ or greater. Vegetation: Hija and Spai contributed about equally to IV, cover, density, and frequency totals, and Artr dominated the cover variable contributing $41.1 \%$ of the total (table 17). Bogr was ranked fourth, and Gusa occurred in $32 \%$ of the sample plots with a cover value of nearly $5 \%$ of the total. Seven of the 17 species accounted for $90 \%$ or greater of the four variable totals. Hija and Spai were co-dominant, whereas Bogr and Hija were codominants in p.c. 11 including an increase in Gusa. These characteristics were the major separation factors between p.c. 11 and p.c. 12.

Ecological Stage: Mid-seral.

PNV: Existing community structure with increased amount of Agsm and Orhy, and decreased Gusa for a higher seral stage.

\section{Artemisia tridentata - Gutierrezia sarothrae/Bou- teloua gracilis-Agropyron smithii p.c.}

(Artr-Gusa/Bogr-Agsm; big sagebrush-snakeweed/blue grama-western wheatgrass) 
General: This community differs from p.c. 10,11 , and 12 because of the co-dominance of Bogr and Agsm, and a decreased Hija component. Sites occurred between $1,981 \mathrm{~m}$ and $2,256 \mathrm{~m}$ in elevation.

Landform: Alluvial flats.

Soils: Ustic Torriorthent, Galisteo-Unnamed 2+2B series (Assoc. A3);

Typic Torrifluvent, Christainburg and Fruitland series;

Mollic/Lithic Haplargid, Penistaja-Bond series (Assoc. A8) (table 3).

This community occurred on both Entisols and Aridisols represented by seven different series. Most of the soils were fine-loamy texture and mixed. All soils were greater than $152 \mathrm{~cm}$ depth, except for the two series in Association A8 (Appendix A, figs. A2, A4, and A6). A-horizons in the series were generally less than $13 \mathrm{~cm}$ in depth. Bare soil averaged less than $70 \%$, litter was $16.0 \%$, and no surface rock (table 18 ).

Vegetation: Bogr and Agsm contributed about equally to the IV, density, and frequency totals (table 18). Actually, Bogr, Agsm, and Artr each contributed about $20 \%$ to the IV total. Artr ranked first for cover and second with Bogr for frequency. Although seven species had an IV $\geqq 0.1$, only the top three occurred in the six sites used to define this community. The same seven species accounted for greater than $80 \%$ of the IV, cover, and density totals.

Ecological Stage: Mid-high seral, somewhat degraded. PNV: Increased amounts of Sihy, Spcr, Spai and Orhy for high ecological stage. Artr is a permanent component as is Gusa, but reduced in amount.

\section{Artemisia tridentata/Sporobolus cryptandrus- Oryzopsis hymenoides p.c.}

(Artr/Spcr-Orhy; big sagebrush/sand dropseed-Indian ricegrass)

General: This was a minor community as far as representation within the study area, but approached one of the few high ecological stage communities. Elevation of the community was $2,134 \mathrm{~m}$.

Landform: Alluvial flat.

Soils: Lithic/Typic Torriorthant, Travessilla-Persayo series (Assoc. A2) (table 3).

This Entisol association was loamy, mixed, and shallow. Effective soil depth was less than $25 \mathrm{~cm}$; both series had A1-horizons less than $13 \mathrm{~cm}$ deep (Appendix A, fig. A1). Litter averaged $17.2 \%$, bare soil was $64.9 \%$ (table 19).

Vegetation: Spcr dominated the IV, cover, density, and frequency variable totals with $45.6 \%, 59.9 \%, 48.5 \%$, and $28.4 \%$, respectively (table 19). Artr ranked second for all variables. The IV for Orhy was $\geqq 0.1$; therefore it was considered important enough to be included in the community name, even though it was a somewhat minor component. Seven species contributed to greater than $80 \%$ of the totals for IV, cover, and density.

Ecological State: High seral.

PNV: Existing community with increased amounts of
Orhy and Agsm. Artr is a permanent component. Control of Chna (Chrysothamnus nauseosus) and Gusa would maintain the seral stage.

\section{Artemisia tridentata-Chrysothamnus parryi/Aris- tida fendleriana-Bouteloua gracilis p.c.}

(Artr-Chpa/Arfe-Bogr; big sagebrush-Parry rabbitbrush/Fendler threeawn-blue grama)

General: This community was minor, but represented a degraded situation; therefore, it was separated. The sample site occurred at $2,073 \mathrm{~m}$ elevation.

Landform: Alluvial flat.

Soils: Typic Torrifluvent, Christainburg series (table 3).

This Entisol was deep, with an effective soil depth of greater than $152 \mathrm{~cm}$ (Appendix A, fig. A4). The A1horizon was less than $13 \mathrm{~cm}$ deep. All horizons were clayey with a pH of 8.6. Litter and bare soil averaged $17.7 \%$ and $70.6 \%$, respectively (table 20 ).

Vegetation: Arfe ranked number one for all variables and contributed $21.6 \%, 24.5 \%, 22.4 \%$, and $11.6 \%$ to total IV, cover, density, and frequency, respectively (table 20 ). Bogr ranked second for IV and density; Artr and Chpa ranked second and third, respectively for total cover. Of the 24 species, 10 contributed greater than $80 \%$ of the variable totals.

Ecological Stage: Low seral.

PNV: Existing community with increased Spai, Orhy, and Agsm; decreased Muri (Muhlenbergia richardsonis), Arfe, and Chpa.

\section{Artemisia nova - A. tridentata/Agropyron cristatum - A. smithii p.c.}

(Arno-Artr/Agcr-Agsm; black sagebrush-big sagebrush/crested-western wheatgrass)

General: This is a minor community, but a unique type because of the dominance of Arno. The typal community was at $2,225 \mathrm{~m}$ elevation.

Landform: Alluvial flat.

Soils: Ustic Torriorthent, Galisteo-Unnamed $2+2 \mathrm{~B}$ series (Assoc. A3) (table 3).

This Entisol soil association consisted of three series having an effective depth of greater than $152 \mathrm{~cm}$. A1-horizans were less than $13 \mathrm{~cm}$ deep with clay to clayloam textures; $\mathrm{pH}$ was 8.2 (Appendix A, fig. A2). Litter, rock, and bare soil averaged $6.8 \%, 0 \%$, and $87.7 \%$, respectively (table 21 ). Black sagebrush usually occurs on shallow soils with lime subsoils. Therefore, the sample site of this p.c. may be an inclusion within the soil association or an ecotone.

Vegetation: Arno ranked first, contributing $22.2 \%$, $40.5 \%$, and $16.0 \%$ for IV, cover, and frequency, respectively; and fourth for density (table 21). Agcr and Agsm contributed nearly equal percentages to the IV, cover, and frequency totals; Artr ranked second in cover contributing $22.6 \%$ of the total. Of the 23 species, 7 accounted for greater than $70 \%$ of the variable totals. Even 
though Agcr was an introduced species, it was considered part of the PNV and, therefore, was included in the community name. The sample site appears to be converted, and black sagebrush may have been planted, especially because the soil association (A3) does not conform to the species natural requirements.

Ecological Stage: Mid-seral.

PNV: Existing community with retention of Agcr and increased Orhy.

\section{Artemisia nova - Gutierrezia sarothrae/Bouteloua gracilis - Hilaria jamesii p.c.}

(Arno-Gusa/Bogr-Hija; black sagebrush-snakeweed/ bluegrama-galleta)

General: This is a minor community, but unique and representative of a degraded condition. The sample intensity was very low because of site confounding, but was included as a typal example within the study area because of the black sagebrush aspect, soil, and landform. The sample site occurred at $2,195 \mathrm{~m}$ elevation. Landform: Breaks.

Soils: Ustic Torripsament/Torrifluvent, SheppardUnnamed 13 series (Assoc. A9) (table 3).

This Entisol association consisted of two series with depths of greater than $152 \mathrm{~cm}$ (Appendix A, fig. A3). Textures were loamy-sand or clayey. A-horizons were less than $13 \mathrm{~cm}$ deep, and each modal profile consisted of at least three $\mathrm{C}$-horizons with $\mathrm{pH}$ averaging about 8.8. Bare soil was $81.2 \%$, and litter was $13.4 \%$ (table 22 ). The sample site was confounded and appeared to be an inclusion within soil Association A9; black sagebrush usually occurs on shallow, lime subsoils.

Vegetation: Bogr dominated the IV, density, and frequency totals, and contributed equally along with Gusa and Arno to total cover (table 22). Gusa and Arno were co-dominant for IV, cover, and frequency. Of the 15 species, 6 accounted for greater than $85 \%$ of the totals for IV, cover, and density.

Ecological Stage: Low-mid seral.

PNV: Existing vegetation plus increased amount of Mumo (Muhlenbergia montana) and Kocr, and decreased Gusa, Lepu (Leptodactylon pungens), and Hasp (Haplopappus spinulosus) under proper management for higher ecological stage. Site conditons may preclude reduction of Gusa, Lepu, and Hasp. Arno is a permanent component.

\section{Shrubland Formation...Chrysothamnus Subformation ...C. nauseosus ssp. bigelovii, C. parryi, C. nauseosus ssp. graveolens Series}

The three communities classified within the Chrysothamnus subformation consisted of sites which had two subspecies of Chna (Chrysothamnus nauseosus), or Chpa (Chrysothamnus parryi) dominating the shrub synusia with an IV $\geqq 0.1$ and at least one grass as the dominant understory synusia (fig. 9). These series occurred on two

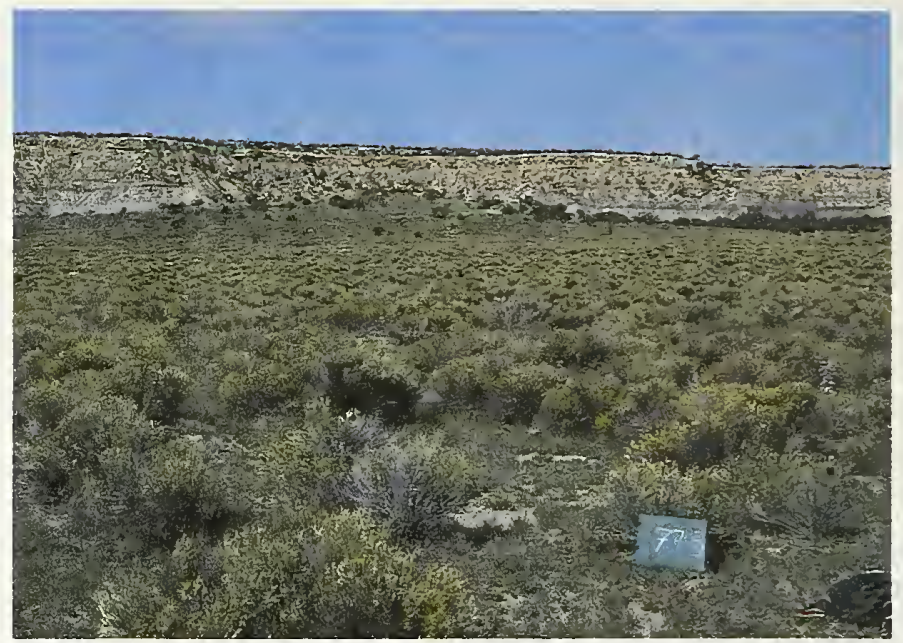

Figure 9.-Representative photo of the Chrysothamnus subformation. Pictured is the Chrysothamnus parryi/Hilaria jamesii Bouteloua gracilis plant community (p.c. 19).

soil orders, an azonal alluvial soil, and one landform. The subformation was a major component, but was restricted in area.

\section{Chrysothamnus nauseosus ssp. bigelovii/Bouteloua gracilis-Agropyron smithii p.c.}

(Chnab/Bogr-Agsm; Bigelow rubber rabbitbrush/blue grama-western wheatgrass)

General: This is a minor community, but unique because of the rabbitbrush subspecies differentiation. Only two transects were used to describe this abstract community due to site confounding. The sample site elevation was $2,057 \mathrm{~m}$.

Landform: Alluvial flats.

Soils: Ustollic Camborthid, Las Lucas-Unnamed 7B series (Assoc. A6) (table 3).

The series in this Aridisol association were silty-loams with depths of $76 \mathrm{~cm}$ or greater. The A1-horizons were less than $13 \mathrm{~cm}$ is depth with an $8.2 \mathrm{pH}$; subsurface $\mathrm{pH}$ values averaged 8.8 (Appendix A, fig. A5). Bare soil was $54 \%$ and surface litter was $16.3 \%$ (table 23 ).

Vegetation: Bogr ranked first for contributions to IV, cover, density, and frequency total with $45.8 \%, 64.7 \%$, $44.6 \%$, and $28.1 \%$, respectively (table 23 ). Agsm was ranked second for all variables except cover, in which Chnab ranked second with $13.8 \%$ of the total. Of the 18 species, 6 accounted for $85 \%$ or greater of the totals for IV, cover, and density. Chpa, Gusa, and Artr were components, but in minor amounts.

Ecological Stage: Mid-seral.

PNV: Existing vegetation plus increased Sihy, Scpa (Schedonnardus paniculatus), and Orhy. Artr probably will replace Chnab. Selective management could be applied to control Chnab.

\section{Chrysothamnus parryi/Hilaria jamesii-Bouteloua gracilis p.c.}

Chpa/Hija-Bogr; Parry rabbitbrush/galleta-blue grama) 
General: This community is similar to p.c. 18 and 20 except for the Chrysothamnus species and subspecies, and the dominance of Bogr, Hija, and Agsm. The community occurred between $2,042 \mathrm{~m}$ and 2,134 m elevation.

Landform: Alluvial flats.

Soils: Typic Torripsament, Berent series;

Typic Torrifluvent, Fruitland series;

Alluvial (table 3).

This community occurred on two Entisol series and azonal alluvial land. The series were greater than 152 $\mathrm{cm}$ in depth and ranged from sandy to loamy textures (Appendix A, figs. A4 and A7). A1-horizon $\mathrm{pH}$ averaged 7.4 and subsurface $\mathrm{pH}$ ranged from 7.6 to 8.8. Litter, rock, and bare soil averaged $10.6 \%, 0 \%$, and $78.7 \%$, respectively (table 24 ).

Vegetation: Bogr ranked number one for all variables, and Chpa ranked second for cover accounting for $21.5 \%$ of the total (table 24). Spai and Agsm also were components of the community, with IV $\geqq 0.1$. Seven species with IV $\geqq 0.1$ accounted for more than $85 \%$ of the variable totals.

Ecological Stage: High-mid seral.

PNV: Existing community structure with possible increase and extension of Cela and Orhy.

\section{Chrysothamnus nauseosus ssp. graveolens/Boutel-} oua gracilis - Agropyron smithii p.c.

(Chnag/Bogr-Agsm; green plume rubber rabbitbrush/ blue grama-western wheatgrass)

General: This minor community is similar to p.c. 18 except for a different subspecies of rubber rabbitbrush and a lower diversity. The sample intensity was small because of site confounding and subspecies differences within the sample sites. Elevation of the sample site was $2,057 \mathrm{~m}$.

Landform: Alluvial flats.

Soils: Typic Torrifluvent, Ravola series (table 3).

The community sample site occurred on a fine-silty Entisol series with a depth greater than $152 \mathrm{~cm}$. The A1-horizon was $25 \mathrm{~cm}$ deep and was silty-clay loam with a pH of 8.8 (Appendix A, fig. A4); only p.c. 20 and 39 occurred on this soil series. Bare soil was $35.4 \%$, one of the lowest for all communities; litter was $24.1 \%$, one of the highest (table 25).

Vegetation: Bogr accounted for $70 \%$ or more of the totals for IV, cover, and density (table 25). Chnag was ranked fourth for IV, but second for cover, accounting for $17.4 \%$ of the total value. Four of the seven species accounted for greater than $93 \%$ of all variable totals. Because of the dominance of Bogr cover (75.1\%), this community had a very low diversity index of 0.74 . Spcr was a minor component.

Ecological Stage: Mid-seral.

PNV: Existing community with increased amounts of Agsm and Spcr; decreased Chnag.

\section{Shrubland Formation...Sarcobatus Subformation ...S. vermiculatus Series}

Two communities were classified within the Sarcobatus subformation, which consisted of sites

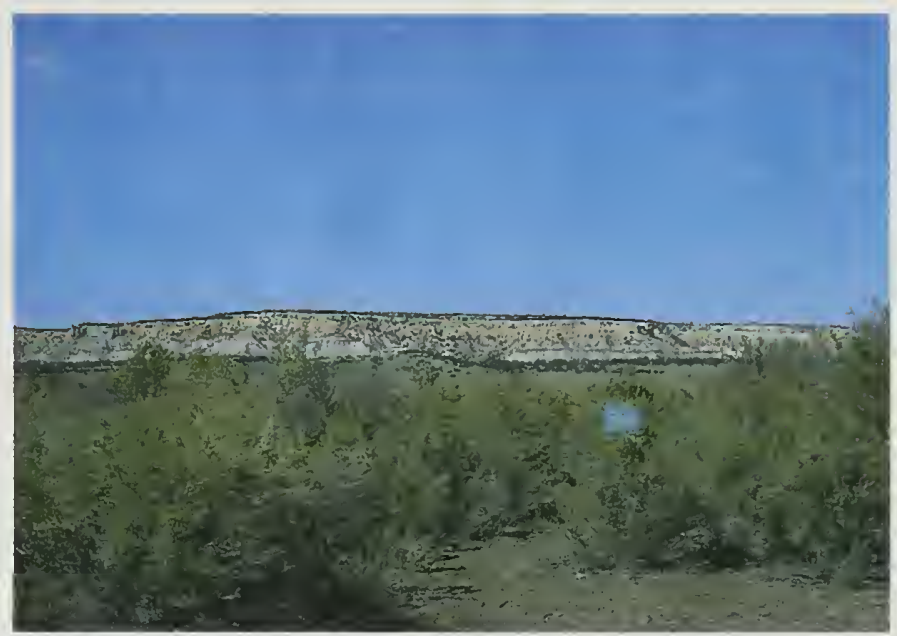

Figure 10. - Representative photo of the Sarcobatus subformation. Pictured is the Sarcobatus vermiculatus plant community (p.c. 21).

dominated by Save (Sarcobatus vermiculatus) in the shrub synusia with an IV $\geqq 0.1$ (fig. 10). One community was mono-specific; the other was dominated by an understory grass synusia. The series occurred on only one soil order, soil series, and landform. The series represented a major component of the study area, especially on alluvial flats.

\section{Sarcobatus vermiculatus p.c.}

(Save; black greasewood)

General: This is essentially a degraded phase of p.c. 22 and a single species community dominated by Save. The p.c. occurred between 2,012 and 2,073 m elevation on a single soil series. However, the soil series was not restricted to this community.

Landform: Alluvial flats.

Soils: Typic Torrifluvent, Christainburg series (table 3).

This Entisol series supported several communities and had a depth of greater than $152 \mathrm{~cm}$ with A1/AC-horizons of less than $25 \mathrm{~cm}$ (Appendix A, fig. A4). The texture was clayey with an $8.6 \mathrm{pH}$. Bare soil was $84.9 \%$ and litter averaged $15.1 \%$ (table 26).

Vegetation: Save was the predominant species within this community (table 26). Only two other species occurred; Chna was minor, and an annual Atriplex sp. (ATRI). The community was named only after Save; the annual component was not included. Shrubs were the only plants within this community. The community exhibited the lowest diversity index with a value of 0.17 .

Ecological Stage: Low seral.

PNV: Save with possible invasion by Agsm and Sihy yielding a higher ecological stage similar to p.c. 22.

\section{Sarcobatus vermiculatus/Sitanion hystrix - Agropy- ron smithii p.c.}

(Save/Sihy-Agsm; black greasewood/bottlebrush squirrel tail-western wheatgrass) 
General: This community represented the non-degraded equivalent of p.c. 21 with six additional species, including four grasses. It occurred at an elevation of 1,981 m and occupied a niche along riparian terraces.

Landform: Alluvial flats.

Soils: Typic Torrifluvent, Christainburg series (table 3).

The community was supported by this Entisol series only; but this series did not support this community only. The Christainburg series exceeded $152 \mathrm{~cm}$ in depth, with a clay textured A1-horizon of less than $25 \mathrm{~cm}$ deep (Appendix A, fig. A4). Surface litter was $8.7 \%$, and bare soil averaged $\mathbf{8 5 . 3 \%}$ (table 27 ).

Vegetation: Save dominated cover by accounting for $55.9 \%$ of the total, and essentially shared the IV total with Sihy and Agsm with $33.5 \%, 32.5 \%$, and $27.2 \%$, respectively (table 27). Save, Sihy, and Agsm accounted for $\mathbf{9 0} \%$ or more of the four variables. Also, these three species had an IV $\geq 0.8$; the next highest species, Chna, had an IV of 0.07 . The diversity of this community was somewhat low, 1.09, because the three dominant species accounted for $96.2 \%$ of the total density.

Ecological Stage: Mid-high seral.

PNV: Existing community with increased Spai.

\section{Shrubland Formation...Ceratoides Subformation ...C. lanata Series}

The two communities classified within the Ceratoides subformation consisted of sites which had Cela dominating the shrub synusia with an IV $\geqq 0.1$ and at least one grass species as a dominant understory synusia (fig. 11). The series occurred on two soil orders, one complex, and three landforms. The series was minor in areal extent, but represented an important study area component.

\section{Ceratoides lanata - Gutierrezia sarothrae/Hilaria jamesii p.c.}

\section{(Cela-Gusa/Hija; winterfat-snakeweed/galleta)}

General: This is a degraded winterfat community evidenced by the status of Gusa and high percentage of bare soil. It differs from p.c. 24 primarily by the change in dominant grass species. Sample sites occurred between $1,737 \mathrm{~m}$ and $2,042 \mathrm{~m}$ in elevation.

Landform: Alluvial flats.

Soils: Ustic/Lithic Torriorthent, Shingle-Travessilla series (Assoc. A1);

Typic Torrifluvent, Billings series;

Ustollic Camborthid, Las Lucas-Únnamed 7B series (Assoc. A6);

Rock outcrop-Gypsum (Complex C3) (table 3).

Sample sites occurred on series within both Entisol and Aridisol orders, and on an azonal complex. Association $\mathrm{A} 1$ was less than $38 \mathrm{~cm}$ deep; the other soils were generally greater than $127 \mathrm{~cm}$ in depth; all were loamy (Appendix A, figs. A1, A3, A5, and A8). Sites were not specific to a particular soil series, indicating a wide ecological species amplitude. Bare soil, litter, and rock

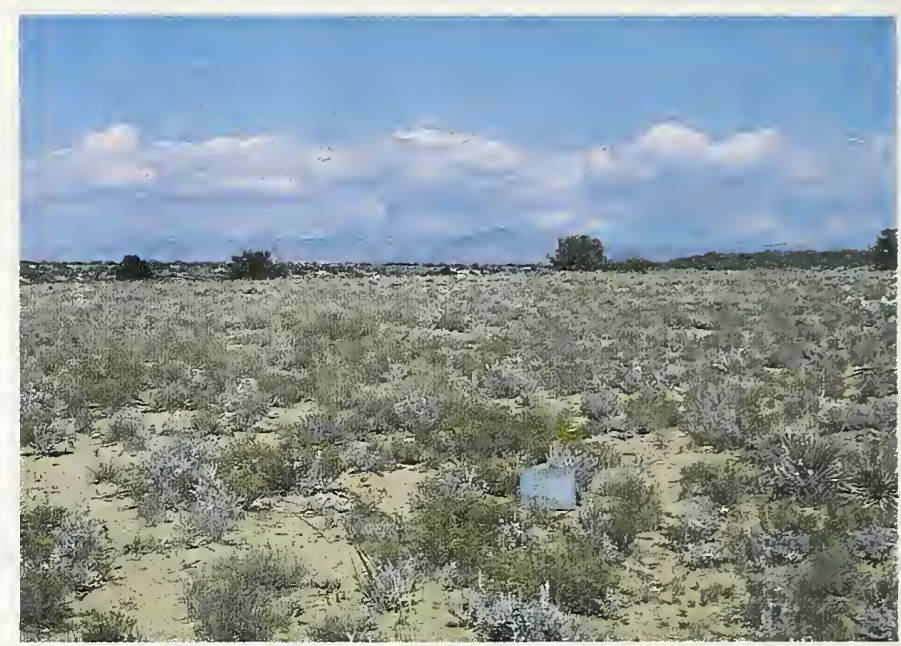

Figure 11.-Representative photo of the Ceratoides subformation. Pictured is the Ceratoides Ianata - Gutierrezia sarothrae/Hilaria jamesii plant community (p.c. 23).

averaged $89.7 \%, 3.0 \%$, and $0.2 \%$, respectively (table 28 ). Vegetation: Hija dominated and accounted for $38.3 \%$, $31.9 \%, 56.4 \%$, and $23.8 \%$ of the total IV, cover, density, and frequency, respectively (table 28). Gusa was ranked second and Cela third for most variables. Of the 36 species, 7 contributed greater than $80 \%$ to the totals for IV, cover, and density. Sihy, Bogr, and Orhy were consistent components in minor amounts.

Ecological Stage: Mid-high seral, but degraded.

PNV: Existing community with decreased Gusa and increased Cela, Spai, and Orhy.

\section{Ceratoides lanata - Gutierrezia sarothrae/Bouteloua gracilis p.c.}

(Cela-Gusa/Bogr; winterfat-snakeweed/blue grama)

General: This community represented a degraded winterfat-alkali sacaton shrubland. The primary difference between this community and p.c. 23 is the dominance of Bogr rather than Hija. It may be conceivable to merge p.c. 23 and p.c. 24 if the separation between Bogr and Hija is not considered significant. Sample sites occurred at elevations between $1,844 \mathrm{~m}$ and $1,957 \mathrm{~m}$. Landform: Alluvial flats and mesas.

Soils: Lithic/Typic Torriorthent, Travessilla-Persayo series (Assoc.A2);

Ustic/Lithic Torriorthent, Shingle-Travesilla series (Assoc.A1);

Ustollic Camborthid, Las Lucas-Unnamed 7B series (Assoc.A6) (table 3).

One sample site occurred in each association; two were on the Entisol series. Effective soil depths within A1- and A2-horizons were less than $38 \mathrm{~cm}$, with silty to clay loam textures (Appendix A, figs. A1 and A5). The Aridisol association (A6) was $102 \mathrm{~cm}$ or greater in depth with loamy textures. A1-horizons were less than $13 \mathrm{~cm}$ in depth with an $8.2 \mathrm{pH}$. Litter, rock, and bare soil averaged $3.5 \%, 0 \%$, and $84.5 \%$, respectively (table 29 ). Vegetation: Bogr dominated the IV, cover, and density 
values by contributing $46.7 \%, 52.3 \%$, and $66.6 \%$ of the totals, respectively; Hija ranked second and was codominant with Bogr for frequency (table 29). Gusa and Cela were ranked third and fourth, respectively for all variables. The four top-ranked species accounted for more than $80 \%$ of the totals for IV, cover, and density. Spai, Orhy, and Spcr were constant community members, but with an IV $<0.1$. Cela is a suffrutescent and therefore this community could be classified as p.c. 31 or p.c. 32 with a Cela synusia.

Ecological Stage: Mid-seral; degraded.

PNV: Existing community plus increased amounts of Cela, Spai, Orhy, Spcr and decreased Gusa.

\section{Shrubland Formation...Atriplex Subformation} ...A. cuneata, A. obovata, A. canescens Series

Six communities were classified within the Atriplex subformation consisting of sites which had Atcu (Atriplex cuneata), Atob (A. obovata), or Atca (A. canescens) dominating the shrub synusia with an IV $\geq 0.1$ and at least one grass as an understory synusia. The series occurred on one soil order and two landforms. The series was a major study area component in both areal extent and niche occupation (fig. 12).

\section{Atriplex cuneata - Frankenia jamesii/Sporobolus airoides p.c.}

(Atcu-Frja/Spai; moundscale-Frankenia/alkali sacaton)

General: This is a minor community, but unique because of Atcu and Frja. The sample site occurred at 1,783 m on moderate slopes.

Landform: Colluvial slopes.

Soils: Ustic/Lithic Torriorthent, Shingle-Travessilla series (Assoc.A1) (table 3).

This Entisol association consisting of two series was shallow and eroded; soil depth was less than $51 \mathrm{~cm}$ (Appendix A, fig. A1). Texture was fine-sandy-loam to silty-

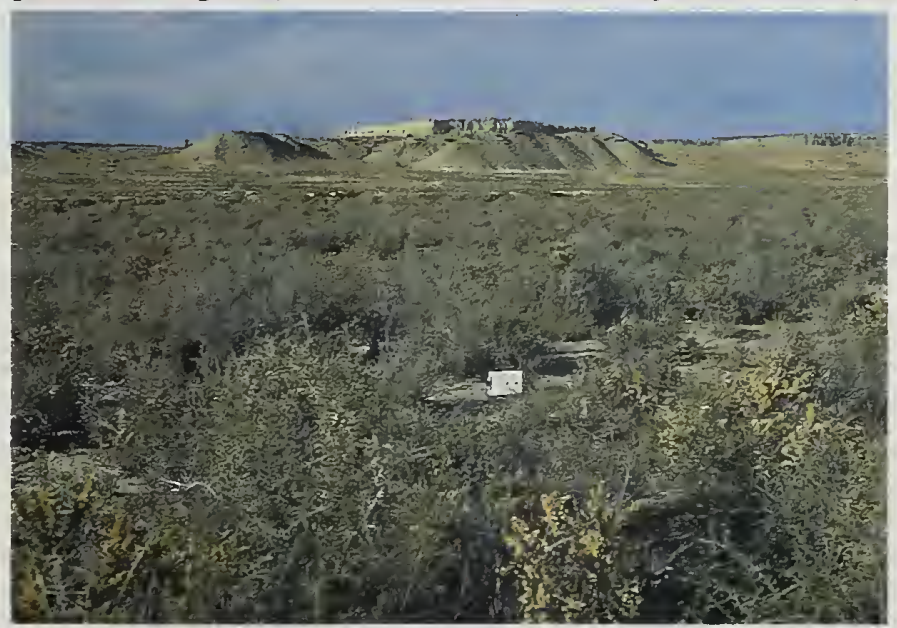

Figure 12.-Representative photo of the Atriplex subformation. Pic. tured is the Atriplex canescens/Sporobolus airoides-Sitanion hystrix plant community (p.c. 29). clay-loam. Bare soil was $90 \%$ and rock was nearly $5 \%$; surface litter was $0 \%$ (table 30 ).

Vegetation: Spai dominated the totals of IV, density, and frequency with values of $34.4 \%, 48.7 \%$, and $33.3 \%$, respectively (table 30 ). Frja and Atcu were ranked first and second for cover, with $28.4 \%$ and $31.6 \%$ of the total, respectively. Cela occurred in $40 \%$ of the plots and was ranked second in frequency, accounting for $14.8 \%$ of the total. Of the 13 species, 8 contributed $85 \%$ or more to the variable totals.

Ecological Stage: Mid-seral; degraded.

PNV: Current community with sustained amounts of Spai and increased Cela.

\section{Atriplex obovata/Sporobolus airoides - S. crypt- andrus p.c.}

(Atob/Spai-Spcr; ovate saltbush/alkali sacaton-sand dropseed)

General: This was a minor community, but unique because of Atob. It differed from p.c. 27 because of the dominance of Atob and very low diversity. One of the sites representing this community was Atob monospecific; but size restricted intensive sampling and a separate community. Sample site elevation was $1,829 \mathrm{~m}$. Landform: Alluvial flats.

Soils: Typic Torrifluvent, Christainburg series; Alluvial (table 3).

Most of this community occurred on an Entisol series, which had an effective soil depth of less than $25 \mathrm{~cm}$ with a clay texture (Appendix A, figs. A4 and A7). The Alluvial land was loamy textured to a depth of $25 \mathrm{~cm}$, with a stratified subsurface of greater than $178 \mathrm{~cm}$. Bare soil was $90 \%$ and litter was $5.2 \%$ (table 31 ).

Vegetation: Atob dominated the totals of IV, cover, and frequency with values of $58.7 \%, 71.2 \%$, and $53.6 \%$, respectively (table 31 ). Spai dominated the density total with $54.2 \%$, and ranked second for the other three variables. The diversity of this community was only 0.24 ; three of the eight species accounted for $93 \%$ or greater of the variable totals.

Ecological Stage: Mid-high seral, degraded.

PNV: Existing community.

\section{Atriplex obovata - Gutierrezia sarothrae/Hilaria jamesii-Sporobolus airoides p.c.}

(Atob-Gusa/Hija-Spai; ovate saltbush-snakeweed/galleta-alkali sacaton)

General: This is a somewhat minor community, similar to p.c. 26 without the major dominance of Atob, and more degraded by the presence of Gusa. The sites for this community occurred at an elevation of $1,811 \mathrm{~m}$.

Landform: Alluvial flats.

Soils: Ustic/Lithic Torriorthent, Shingle-Travessilla series (Assoc.A1) (table 3).

The Entisol association on which this community occurred was the same as for p.c. 26. The soils were 
shallow, with an effective depth of less than $51 \mathrm{~cm}$. Textures were fine-sandy-loam to silty-clay-loam (Appendix A, fig. A1). Litter was less than $3 \%$, and bare soil was almost 91\%; rock was insignificant (table 32).

Vegetation: Hija dominated the totals of IV, cover, density, and frequency with values of $43.1 \%, 34.9 \%, 64.5 \%$, and $30.7 \%$, respectively (table 32 ). Spai was ranked second and Atob third for all variables. Gusa accounted for $11.4 \%, 10.4 \%, 5 \%$, and $18.8 \%$ of the totals for IV, cover, density, and frequency, respectively. The contribution of Gusa was not major; but, given the amount of bare soil and sparseness of associated species, Gusa has the potential to influence niche-space and reduce production. Of the 14 species, 5 accounted for $90 \%$ or more of the variable totals. Average plant density was only 14.4 plants $/ 0.5 \mathrm{~m}^{2}$.

Ecological Stage: Mid-high seral; degraded.

PNV: Existing vegetation with increased Spcr and Cela; decreased Gusa and OPUN species (Optunia spp.).

\section{Atriplex canescens/Hilaria jamesii p.c.}

(Atca/Hija; fourwing saltbush/galleta)

General: This community was represented by only one site, which was confounded, but which represented a unique floristic aspect. Atca dominated cover, and Hija dominated density. The site occurred at an elevation of $1,722 \mathrm{~m}$. This community could be combined with p.c. 29.

Landform: Alluvial flats.

Soils: Ustic Torripsament/Torrifluvent, Sheppard-Unnamed 13 series; (Assoc. A9) (table 3).

This Entisol association had an A-horizon depth of less than $13 \mathrm{~cm}$ and a total pedon depth of greater than $152 \mathrm{~cm}$. Textures were silty-clay-loam and loamy-sand (Appendix A, fig. A3). Surface litter was 13.4\%, and bare soil was $83.3 \%$; rock was insignificant (table 33 ).

Vegetation: Atca and Hija essentially co-dominated the IV total value with $23.6 \%$ and $22.3 \%$, respectively (table 33). However, Atca contributed $70.7 \%$ of total cover, and Hija contributed $43.7 \%$ of total density. Spai, Sihy, and Bogr were minor components of all variables accounting for $0 \%$ of the density and frequency variables, and IVs $<0.1$.

Ecological Stage: Low seral.

PNV: Existing vegetation with increased Spne and Spai, and persistent Gusa.

\section{Atriplex canescens/Sporobolus airoides - Sitanion hystrix p.c.}

(Atca/Spai-Sihy; fourwing saltbush/alkali sacatonbottlebrush squirrel tail)

General: This community was very common in the study area both in number of representative sites and area. The sites occurred at elevations between $1,524 \mathrm{~m}$ and $1,890 \mathrm{~m}$. Atca and three species of Sporobolus were con- sistent; Atob and Chvi (Chrysothamnus vicidiflorus) occasionally were present.

Landform: Alluvial flats.

Soils: Typic Torrifluvent, Billings series;

Typic Torrifluvent, Christainburg series;

Ustic Torrifluvent, Kim series;

Alluvial (table 3).

Each of the sites within this community occurred on a different Entisol series and on azonal alluvial land. The A1-horizons were less than $13 \mathrm{~cm}$ deep and were loamy textured (Appendix A, figs. A3, A4, and A8). Total soil depth exceeded $152 \mathrm{~cm}$, surface $\mathrm{pH}$ exceeded 8.2, and textures included a clay fraction. Bare soil and litter averaged $77 \%$ and $17 \%$, respectively; rock was insignificant (table 34).

Vegetation: Spai dominated the totals for IV, density, and frequency with values of $31.6 \%, 50.6 \%$, and $27.3 \%$, respectively (table 34 ). Atca dominated cover, with $54.6 \%$ of the total value, and ranked second for IV. Gusa had an IV $>0.1$, but was a minor component, occuring in less than $10 \%$ of the plots. Of the 26 species, 6 accounted for nearly $80 \%$ or greater of the variable totals. Density of all species averaged 9 plants $/ 0.5 \mathrm{~m}^{2}$. Bogr was a very minor, inconsistent component.

Ecological Stage: High seral.

PNV: Existing community with increased Sporobolus species.

\section{Atriplex canescens - Gutierrezia sarothrae/Boutel- oua gracilis-Sporobolus crytandrus p.c.}

(Atca-Gusa/Bogr-Spcr; fourwing saltbush-snakeweed/ blue grama-sand dropseed)

General: This community is essentially a degraded component of p.c. 29, with dominant Gusa cover and frequency. Sample sites occurred at an elevation of $1,768 \mathrm{~m}$. Landform: Alluvial flats.

Soils: Ustic Torripsament/Torrifluvent, Sheppard-Unnamed 13 series (Assoc. A9) (table 3).

The Entisol series within this association exceeded 152 $\mathrm{cm}$ in depth, with A-horizons of less than $13 \mathrm{~cm}$ (Appen$\operatorname{dix}$ A, fig. A3). Textures were loamy-sand and clay. Litter was less than $4 \%$, and bare soil averaged $93.1 \%$ (table 35 ). Vegetation: Gusa dominated the totals of IV and cover, with values of $21.5 \%$ and $34.5 \%$, respectively (table 35 ). Bogr ranked second for IV and first for density. Spcr occurred in $45 \%$ of all plots and ranked first in frequency. Atca was ranked sixth for IV and second for cover, with $8.5 \%$ and $20.6 \%$ of the totals, respectively. Of the 19 species, 8 accounted for greater than $85 \%$ of the variable totals. Spai did not have an IV $\geqq 0.1$.

Ecological Stage: Low-mid seral; degraded.

PNV: Existing community with decreased Gusa and increased Sporobolus species.

\section{Grassland Formation...Bouteloua Subformation ...B. gracilis, B. eriopoda Series}

The five communities classified in the Bouteloua subformation consisted of sites which had Bogr or Boer 
dominating the grass lifeform and a half-shrub synusia dominated by Gusa with an IV $\geqq 0.1$ (fig. 13). The series occurred on all three soil orders, one soil complex, and three landforms. The subformation was a major and dominant component in the study area.

\section{Bouteloua gracilis - Hilaria jamesii p.c.}

(Bogr-Hija; blue grama-galleta)

General: This community is similar to p.c. 32 except it appears to be in a higher seral stage and less degraded because of the minor contribution of Gusa. Sample site elevation was $1,890 \mathrm{~m}$.

Landform: Alluvial flats.

Soils: Typic Torrifluvent, Billings series (table 3).

This series in the Entisol order had an A1-horizon of less than $13 \mathrm{~cm}$ deep and a total pedon depth of nearly $178 \mathrm{~cm}$ (Appendix A, fig. A3). Horizon profiles were siltyclay-loam in texture, and ranged from 8.2 to 8.8 in pH. Bare soil was $66.8 \%$, litter was $2.3 \%$, and surface rock was zero (table 36 ).

Vegetation: The variables of IV, cover, density, and frequency were dominated by Bogr with values of $38.7 \%$, $45.2 \%, 41.0 \%$, and $30.8 \%$, respectively (table 36 ). Hija ranked second for all variables, and Spcr and Spai were major contributors. Of the 13 species, 5 accounted for $90 \%$ or greater of the variable totals. Density averaged 25.7 plants $/ 0.5 \mathrm{~m}^{2}$, with a gama diversity of 1.33 .

Ecological Stage: Mid-high seral.

PNV: Existing vegetation with increased Boer.

\section{Gutierrezia sarothrae/Bouteloua gracilis - Hilaria jamesii p.c.}

(Gusa/Bogr-Hija; snakeweed/blue grama-galleta)

General: The community was well represented within the study area. It was similar to p.c. 31 but degraded. The sample sites ranged between $1,859 \mathrm{~m}$ and $2,103 \mathrm{~m}$ elevation.

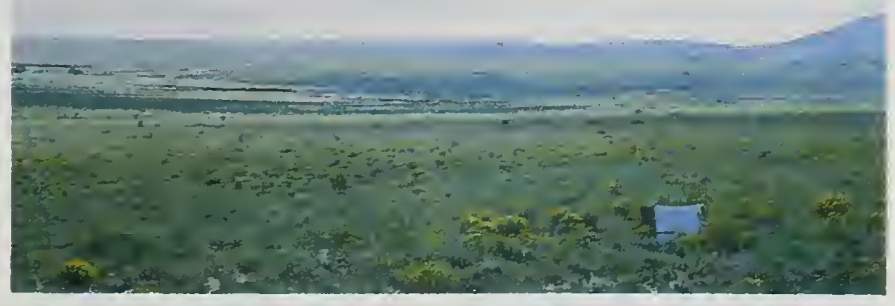

Figure 13.-Representative photo of the Bouteloua subformation. Pictured is the Gutierrezia sarothrae/Bouteloua gracilis.Hilaria jamesii plant community (p.c.32).
Landform: Mesas and alluvial flats.

Soils: Lithic/Typic Torriorthent, Shingle-Persayo series (Assoc. A2);

Typic Torrifluvent, Billings series;

Ustollic Camborthid, Las Lucas-Unnamed 7B (Assoc. A6);

Mollic/Lithic Haplargid, Penistaja-Bond series (Assoc. A8);

Basalt Outcrops-Orthents-Ustolls (Complex C1) (table 3).

This community occurred on several Entisol and Aridisol associations, and one complex. The series in A2 and $A 8$ were shallow, with effective depths of about 51 $\mathrm{cm}$ (Appendix A, figs. A1, A3, A5, A6, and A8); textural class was loamy. The Billings series and Association A6 were greater than $89 \mathrm{~cm}$ in depth; A1-horizons were less than $13 \mathrm{~cm}$ deep; textural classes were loamy. Litter averaged $2.6 \%$, bare soil was $83.7 \%$, and rock was insignificant (table 37 ).

Vegetation: Bogr accounted for $49.1 \%, 52.9 \%, 71.2 \%$, and $25.4 \%$ of the totals for IV, cover, density, and frequency, respectively (table 37). Hija and Gusa occurred in $79.6 \%$ and $44.4 \%$ of the plots, respectively. Of the 29 species, 4 contributed to $93.2 \%$ of the total density, which accounted for the low gama diversity of 0.95 ; mean density was 75.8 plants $/ 0.5 \mathrm{~m}^{2}$.

Ecological Stage: Mid-seral; degraded.

PNV: Existing community plus increased Spcr, Spai, Orhy, Cela, and Agsm with decreased amounts of Gusa.

\section{Gutierrezia sarothrae/Bouteloua gracilis - B. eriopoda p.c.}

(Gusa/Bogr-Boer; snakeweed/blue grama-black grama)

General: This was a minor community, but representative of a higher seral stage, yet somewhat degraded. The sample site occurred at an elevation of $1,951 \mathrm{~m}$.

Landform: Colluvial slope.

Soils: Rock outcrops-Orthents-Ustolls (Complex C1) (table 3).

This Entisol-Mollisol complex was stoney-clay loam, with a median depth of $51 \mathrm{~cm}$ (Appendix A, fig. A8). Bare soil averaged $48.7 \%$, litter was less than $1 \%$, and rock averaged $32.3 \%$ (table 38 ).

Vegetation: Of the 18 species, 5 accounted for $90 \%$ of the totals for IV, cover, and density (table 38). Bogr dominated all variables except frequency, and Boer accounted for $22.1 \%, 25.2 \%, 20.3 \%$, and $20.7 \%$ of the totals for IV, cover, density, and frequency, respectively. Hija and Gusa essentially ranked third and fourth, respectively, for all variables; Gusa occurred in $40 \%$ of the plots. Ecological Stage: Mid-high seral; degraded.

PNV: Existing community with increased Boer, Stne (Stipa neomexicana), and Cela, and decreased Gusa and Hija.

\section{Bouteloua gracilis - Sporobolus airoides p.c.}

(Bogr-Spai; blue grama-alkali sacaton)

General: This is somewhat of an artificial community because of its conversion from PJ and seeding with 
several Agropyron species. However, it is included as a distinct community because of its uniqueness and PNV. The sample site was at $2,240 \mathrm{~m}$.

Landform: Mesa.

Soils: Typic Torriorthent, Persayo series (table 3).

This Entisol series had an effective soil depth of less than $25 \mathrm{~cm}$ and a total pedon depth of $152 \mathrm{~cm}$ (Appen$\operatorname{dix}$ A, fig. A1). Texture of the A1-horizon was loam with an $8.2 \mathrm{pH}$. Bare soil accounted for $57.6 \%$, rock was less than $1 \%$, and litter averaged $19.2 \%$ (table 39 ).

Vegetation: Bogr ranked number one for IV, and density accounted for $20.0 \%$ and $27.9 \%$ of the variable totals, respectively (table 39). Spai ranked second for IV and first for cover. Two seeded species, Agde (Agropyron desertorum) and Agin (Agropyron intermedium), had an IV $\geqq 0.1$. Of the 25 species, 8 accounted for about $80 \%$ of the variable totals, and contributed to $88.8 \%$ of the density total, accounting for an alpha diversity of 2.15. Ecological Stage: Mid-seral.

PNV: Current community with increased amounts of Spcr, Agsm, Orhy, Jumo, and Pied.

\section{Gutierrezia sarothrae/Bouteloua eriopoda - Hilaria jamesii p.c.}

(Gusa/Boer-Hija; snakeweed/blue grama-black grama)

General: This was a somewhat degraded, high seral community based on the contribution of Gusa and Boer, respectively. The sample sites occurred between $1,737 \mathrm{~m}$ and $1,829 \mathrm{~m}$ in elevation. The community was a major floristic representative within the study area, but minor in areal extent.

Landform: Mesas.

Soils: Ustic Torriorthent, Kim series;

Basalt outcrops-Orthents-Ustolls (Complex C1) (table 3).

Each of the sample sites within this community occurred on a different soil-an Entisol and an Entisol-Mollisol complex. The Kim series had an A1-horizon less than $13 \mathrm{~cm}$ deep with a loamy texture. The C-horizons were clay-loam with a total pedon depth of $165 \mathrm{~cm}$; $\mathrm{pH}$ varied between 8.2 and 8.8 (Appendix A, figs. A3 and A8). Bare soil averaged $70.7 \%$, rock $12.5 \%$, and litter $4.5 \%$ (table 40).

Vegetation: Boer dominated the variable totals of IV, cover, and frequency with $27.5 \%, 24.4 \%$, and $23.6 \%$, respectively (table 40). Hija ranked first for density, and Gusa essentially ranked third for all variables. Of the 23 species, 9 accounted for $85 \%$ or greater of all variables except frequency. Spcr and Atca had an IV $>0.1$ and were constant but minor components.

Ecological Stage: High-seral; moderately degraded.

PNV: Existing community with increased Stne and Spcr; decreased Gusa.

\section{Grassland Formation...Hilaria Subformation ...H. jamesii Series}

The three communities classified in the Hilaria subformation consisted of sites which had Hija dominating

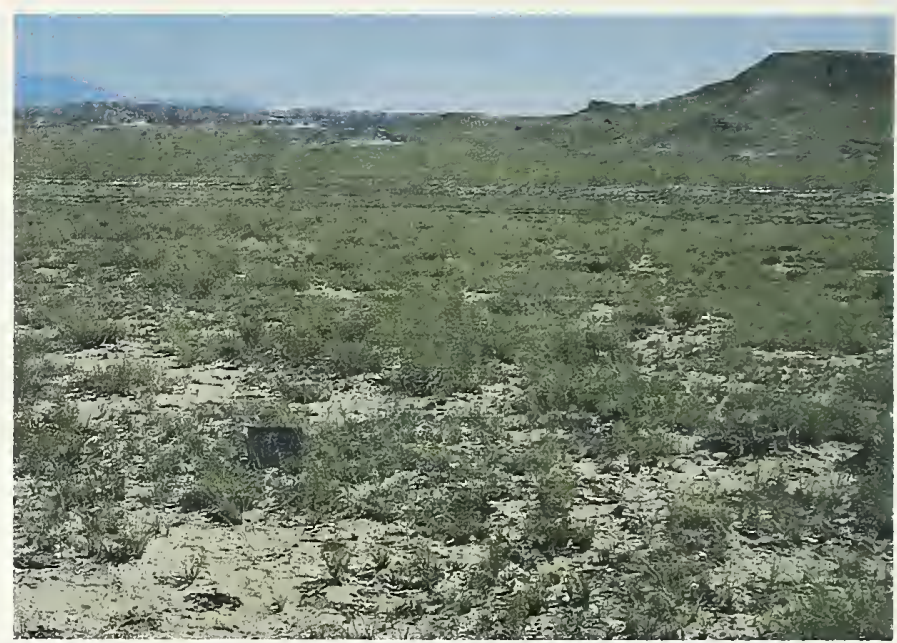

Figure 14. - Representative photo of the Hilaria subformation. Pic. tured is the Hilaria jamesii - Sporobolus airoides plant community (p.c.37).

the grass lifeform and/or Gusa dominating the shrub synusia with an IV $\geqq 0.1$ and a co-dominant grass species (fig. 14). The communities occurred on three soil orders and two landforms. Hija communities were a major and dominant component of the study area in both areal extent and niche occupation.

\section{Gutierrezia sarothrae/Hilaria jamesii - Bouteloua gracilis p.c.}

(Gusa/Hija-Bogr; snakeweed/galleta-blue grama)

General: This was a well-represented community within the study area. It was degraded and represented a major portion of the grassland formation. Sample sites occurred between $1,829 \mathrm{~m}$ and $2,073 \mathrm{~m}$ in elevation. The community differed from p.c. 32 by the dominance reversal of Bogr and Hija.

Landform: Colluvial slopes and alluvial flats.

Soils: Lithic/Typic Torriorthent, Travessilla-Persayo series (Assoc.A2);

Typic Torrifluvent, Billings series;

Ustollic Camborthid, Las Lucas-Unnamed 7B series (Assoc. A6);

Mollic/Lithic Haplargid, Penistaja-Bond series (Assoc. A8);

Lithic Argiustoll, Cabezon series (table 3).

This community occurred on Entisol, Aridisol, and Mollisol series within three associations and two single series. Association A2, A8 and the Cabezon series were shallow, with an effective soil depth of $51 \mathrm{~cm}$ or less (Appendix A, figs. A1, A3, A5, and A7). The Billings series and association A6 were deeper, with soils $76 \mathrm{~cm}$ or more in depth; most textures were fine-loamy to finesilty. Surface litter averaged $5.7 \%$, rock $4.7 \%$, and bare soil $79.2 \%$ (table 41 ).

Vegetation: Hija dominated the variable totals of IV, cover, density, and frequency with $40.2 \%, 36.2 \%, 46.9 \%$, and $32.9 \%$, respectively (table 41 ). Bogr and Gusa ranked second and third, respectively for all variables. Of the 
35 species, 5 accounted for $80 \%$ or more of the totals for IV, cover, and density. The same five species with an IV $\geqq 0.1$, accounted for $92.2 \%$ of total density, which accounted for a relatively low diversity index of 1.26.

Ecological Stage: Mid-seral; degraded.

PNV: Current community with decreased Gusa and increased Spai, Spcr, Orhy, and Cela.

\section{Hilaria jamesii - Sporobolus airoides p.c.}

(Hija-Spai; galleta-alkali sacaton)

General: This community differs from p.c. 41 primarily in the dominance reversal of $\mathrm{Hija}$ and Spai; p.c. 37 represented the degraded phase. The community was well-represented within the study area on alluvial flats. Sample sites occurred between $1,738 \mathrm{~m}$ and $2,073 \mathrm{~m}$. Landform: Alluvial flats.

Soils: Ustic Torripsament, Sheppard-Unnamed 13 series (Assoc. A9);

Typic Torrifluvent, Christainburg series;

Ustic Torriorthent, Kim series;

Ustollic Camborthid, Las Lucas-Unnamed 7B series (Assoc. A6);

Mollic Camborthid, Litle series (table 3).

Each of the five sample sites within this community occurred on a different Entisol or Aridisol series or association, reflecting a wide species ecological amplitude and/or the broad scale of soil mapping. This was the only community which occurred on the Litle soil series. All of the soils exceeded $76 \mathrm{~cm}$ in depth and were fine-loamy textured (Appendix A, figs. A3-A6). Bare soil averaged $83.3 \%$, surface litter $3.3 \%$, and surface rock was insignificant (table 42).

Vegetation: Hija dominated the variable totals of IV, cover density, and frequency with $54.0 \%, 56.0 \%, 71.4 \%$, and $42.6 \%$, respectively (table 42 ). Spai ranked second for all variables.

Ecological Stage: Mid-high seral.

PNV: Current community with increased Spcr, Orhy, and Cela.

\section{Gutierrezia sarothrae/Hilaria jamesii - Sporobolus cryptandrus p.c.}

(Gusa/Hija-Spcr; snakeweed/galleta-sand dropseed)

General: This minor community was considered the degraded phase of p.c. 37 because of Gusa and several minor components. The community was not wellrepresented within the study area. The sample site occurred at $1,890 \mathrm{~m}$. The co-dominance of Spcr was unique.

Landform: Alluvial flats.

Soils: Ustollic Cambortid, Las Lucas-Unnamed 7B series (Assoc. A6) (table 3).

This Aridisol association consisted of two series which had pedon depths of $76 \mathrm{~cm}$ or greater (Appendix A, fig. A5). Horizon textures ranged from loamy, silty-clay- loam, to silty-loam. A1-horizon depths were less than 13 $\mathrm{cm}$, and B-horizons were about $25 \mathrm{~cm}$ in depth. Litter, rock, and bare soil averaged $5.2 \%, 0 \%$, and $88.5 \%$, respectively (table 43).

Vegetation: Hija dominated the variable totals of IV, density, and frequency with values of $36.0 \%, 49.6 \%$, and $29.8 \%$, respectively (table 43 ). Gusa ranked second for IV and first for cover, with $36.7 \%$ of the total. Spcr ranked third for IV and second for frequency. Of the 11 species, 5 accounted for $90 \%$ or more of the variable totals.

Ecological Stage: Mid-seral; degraded.

PNV: Existing community with increased Spai, Orhy, and Agsm; decreased Gusa.

\section{Grassland Formation...Sporobolus Subformation ...S. airoides, S. nealleyi Series}

The six communities classified in the Sporobolus subformation consisted of sites which had Spai, Spne and/or Gusa dominating the grass or shrub synusea with an IV $\geqq 0.1$ and usually a second grass species as a codominant (fig. 15). These series occurred on two soil orders, two complexes, an azonal alluvial soil, and two landforms. This subformation was extremely important and occupied large areal expanses in the study area.

\section{Sporobolus airoides p.c.}

(Spai; alkali sacaton)

General: This community was monospecific and abstracted from only one site, but was representative of a high-seral stage within the study area. The sample site occurred at $1,798 \mathrm{~m}$ elevation.

Landform: Alluvial flats.

Soils: Typic Torrifluvent, Billings series (table 3).

This Entisol series was a deep, silty-clay-loam series. The A1-horizon was less than $13 \mathrm{~cm}$ deep, and the total pedon was greater than $152 \mathrm{~cm}$; pH was generally 8.8 throughout the profile (Appendix A, fig. A1). Within this community, bare soil averaged $83.0 \%$, surface litter was $2.2 \%$, and rock was zero (table 44 ).

Vegetation: Spai dominated all four variables, accounting for $90 \%$ or greater of the totals (table 44). Bogr, Hija, and Atca were very minor components. Because Spai contributed $96.3 \%$ of the total density, the alpha diversity index was only 0.19 .

Ecological Stage: High-seral.

PNV: Existing community.

\section{Sporobolus airoides - Bouteloua gracilis p.c.}

(Spai-Bogr; alkali sacaton-blue grama)

General: This community represented a common entity of the alluvial flats within the study area. The major difference between this community and p.c. 41,42 , and 43 was the co-dominant grass species and/or seral stage. 
If Spai is the major dominant species of interest, p.c. 40, 41 , and 43 could be combined. Sample sites occurred at elevations between $1,829 \mathrm{~m}$ and $1,890 \mathrm{~m}$.

Landform: Alluvial flats.

Soils: Typic Torrifluvent, Billings series;

Typic Torrifluvent, Christainburg series;

Rock outcrops-Gypsum (Complex C3) (table 3).

The two Entisol series supporting this community had A1-horizons less than $13 \mathrm{~cm}$ and total pedon depths of $152 \mathrm{~cm}$ or greater (Appendix A, figs. A3, A4, and A8). Textures ranged from silty-clay-loam to clay and surface horizon $\mathrm{pH}$ averaged 8.7. Bare soil for this community average $71.9 \%$, surface litter was $5.1 \%$, and rock was insignificant (table 45).

Vegetation: Spai dominated the totals of IV, cover, density, and frequency with $43.4 \%, 59.5 \%, 38.7 \%$, and $36.4 \%$, respectively (table 45 ). Bogr ranked second for all variables. Of the 23 species, 4 accounted for $80 \%$ or greater of the variable totals. Spcr and Hija had IV's greater than 0.1 , but were not totally constant.

Ecological Stage: High-seral.

PNV: Current community.

\section{Sporobolus airoides - Hilaria jamesii p.c.}

(Spai-Hija; alkali sacaton-galleta)

General: This community was similar to p.c. 40 and p.c. 43 , except for the switch in co-dominance. The community was a common representative within the study area and occurred between 1,859 $\mathrm{m}$ and 1,981 m elevation. Landform: Alluvial flats.

Soils: Typic Torrifluvent, Christainburg series;

Ustollic Camborthid, Las Lucas-Unnamed 7B series (Assoc. A6);

Alluvial land (table 3).

The Entisol and Aridisol series which supported this community were relatively deep, especially Christainburg which exceeded $152 \mathrm{~cm}$; alluvial land exceeded $178 \mathrm{~cm}$ in depth (Appendix A, figs. A4, A5, and A8). The three series had A1-horizons less than $13 \mathrm{~cm}$ deep. Tex-

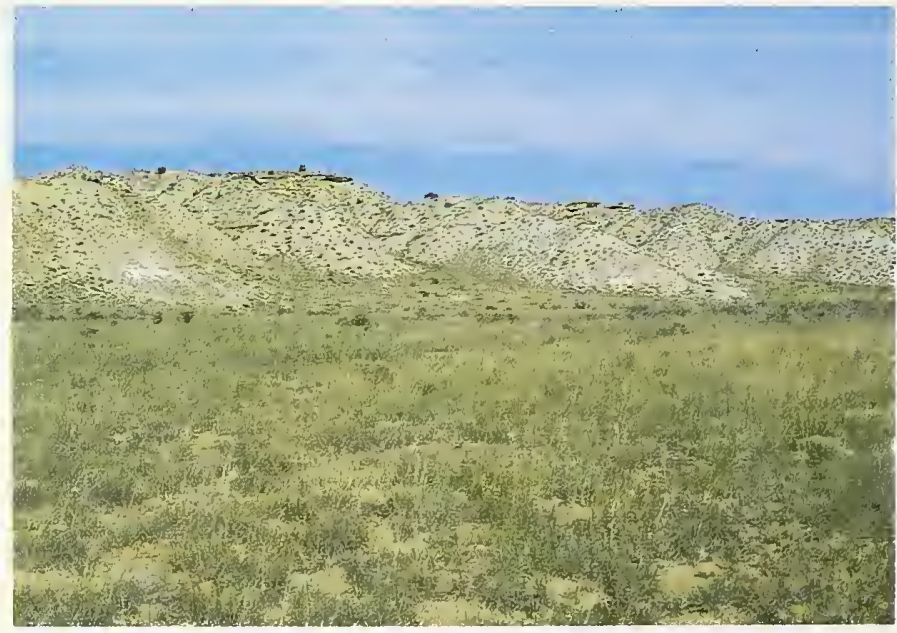

Figure 15. - Representative photo of the Sporobolus subformation. Pictured is the Sporobolus airoides - Bouteloua gracilis plant community (p.c.40). tures ranged from clay to silty-loam. Surface litter averaged $8.0 \%$, rock $0 \%$, and bare soil $68.2 \%$ (table 46 ).

Vegetation: Spai dominated the variable totals of IV, cover, density, and frequency with values of $55.4 \%$, $74.9 \%, 49.4 \%$, and $40.8 \%$, respectively; Hija ranked second for all variables (table 46). Three of the species accounted for greater than $80 \%$ of the variable totals, except for frequency.

Ecological Stage: Mid-high seral.

PNV: Existing community plus increased Agsm and Orhy.

\section{Gutierrezia sarothrae/Sporobolus airoides - Hilaria jamesii p.c.}

(Gusa/Spai-Hija; snakeweed/alkali sacaton-galleta)

General: This community represented the degraded phase of p.c. 41; it was not common within the study area. The sample sites occurred at an elevation of $1,859 \mathrm{~m}$.

Landform: Mesas.

Soils: Ustic-Lithic Torriorthent, Shingle-Travessilla series (Assoc. A1);

Rock outcrops-Orthents (Complex C2) (table 3).

These Entisol soils were shallow, with effective depths of less than $51 \mathrm{~cm}$ and sandy/silty-clay-loam textures (Appendix $A$, figs. $A 1$ and $A 8$ ). Series $\mathrm{pH}$ ranged between 8.0 to 8.2 , and A-horizons were less than $25 \mathrm{~cm}$ deep. Surface litter averaged $5.3 \%$, surface rock $2.3 \%$, and bare soil $87.6 \%$ (table 47 ).

Vegetation: Spai ranked first for total IV and cover, with values of $25.1 \%$ and $31.4 \%$, respectively (table 47 ). Gusa ranked first for frequency, and occurred in $60 \%$ of the sample plots; Hija dominated cover with $33.2 \%$ of the total. Of the 22 species, 4 accounted for nearly $80 \%$ of all variable totals.

Ecological Stage: Mid-seral; degraded.

PNV: Current community with increased Boer, Orhy, and Cela; decreased Gusa.

\section{Sporobolus airoides - Agropyron smithii p.c.}

(Spai-Agsm; alkali sacaton-western wheatgrass)

General: This community was similar to p.c. 40 and p.c. 41 , with the difference being the co-dominance of grass species. This community was not well-represented within the study area. The sample sites occurred between $1,890 \mathrm{~m}$ and $2,012 \mathrm{~m}$.

Landform: Alluvial flats.

Soils: Typic Torrifluvent, Christainburg series (table 3).

This Entisol series was a deep, clay textured soil. The $\mathrm{A} 1$ - and $\mathrm{A} / \mathrm{C}$-horizons were less than $13 \mathrm{~cm}$ deep; $\mathrm{pH}$ was 8.6 (Appendix A, fig. A4). The surface litter averaged $8.0 \%$ and bare soil was $64.9 \%$ (table 48 ).

Vegetation: Spai dominated the totals of IV, cover, density, and frequency with values of $44.7 \%, 64.6 \%, 25.2 \%$, and $31.2 \%$, respectively. Agsm was ranked second for 
all variables (table 48). Spcr and Hija had an $I V \geqq 0.1$, but were minor, although constant components. Ōf the 20 species, 6 accounted for nearly $80 \%$ or more of the variable totals.

Ecological Stage: Mid-high seral.

PNV: Current community.

\section{Sporobolus nealleyi - Bouteloua eriopoda p.c.}

(Spne-Boer; gypgrass-black grama)

General: This was a minor, but unique community. It was considered high seral and restricted to gypsum soils. The sample site occurred at $1,737 \mathrm{~m}$ elevation.

Landform: Mesas.

Soils: Rock outcrops-Gypsum (Complex C3) (table 3).

This soil complex was shallow and contained a significant gypsum fraction (Appendix A, fig. A8). The rock outcrops were sandstone and shale. Surface litter averaged $2.5 \%$, and bare soil was $88.8 \%$ (table 49 ).

Vegetation: Spne was ranked first for IV, density, and frequency accounting for $25.9 \%, 27.4 \%$, and $20.0 \%$ of the totals, respectively (table 49). Boer ranked third for all variables, and Leptodactylon species (LEPT) ranked second, but was not included in the community name. Of the 16 species, 6 accounted for greater than $85 \%$ of the totals for all variables except frequency.

Ecological Stage: High seral.

PNV: Existing community with increased Cela and decreased LEPT species

\section{Grassland Formation...Scleropogon Subformation ...S. brevifolius Series}

This subformation consisted of only one minor, yet unique community dominated by Scleropogon (fig. 16).

\section{Scleropogon brevifolius - Bouteloua gracilis p.c.}

\section{(Scbr-Bogr; burrograss-blue grama)}

General: This was a unique, but minor community which was very restricted in areal extent. The sample

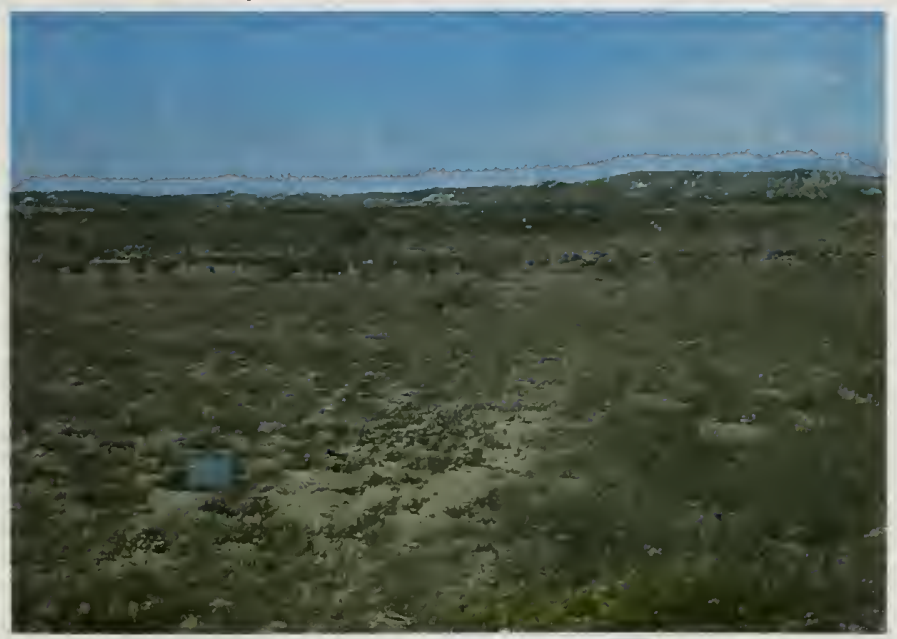

Figure 16. - Representative photo of the Scleropogon subformation. Pictured is the Scleropogon brevifolius - Bouteloua gracilis plant community (p.c.45). site was located at $1,737 \mathrm{~m}$.

Landform: Alluvial flat.

Soils: Ustic Torriorthent, Kim series (table 3).

This Entisol series had a total depth of greater than $165 \mathrm{~cm}$ and a shallow, loamy A1-horizon; most of the horizons were clay-loam (Appendix A, fig. A3). Surface litter averaged $1.1 \%$, and bare soil was $84.2 \%$ (table 50 ). Vegetation: Scbr dominated the variable totals of IV, cover, and density, with values of $34.6 \%, 39.5 \%$, and $39.0 \%$, respectively (table 50 ). Bogr ranked second for all variables; and Scbr, Bogr, and Spcr all ranked equally for frequency with $25.4 \%$ of the total. Of the 13 species, 5 accounted for greater than $90 \%$ of the variable totals. Ecological Stage: Low seral.

PNV: Existing community with decreased Scbr.

\section{LITERATURE CITED}

Aldon, Earl F. and George Garcia. 1971. Stocking rangelands on the Rio Puerco in New Mexico. Journal of Range Management 24(5):344-345.

Aldon, Earl F. and George Garcia. 1973. Seventeen-year sediment production from a semiarid watershed in the Southwest. USDA Forest Service Research Note RM-248, 4 p. Rocky Mountain Forest and Range Experiment Station, Fort Collins, Colo.

Axelrod, Daniel I. 1979. Desert vegetation, its age and origin. p. 1-72. In: Arid land plant resources: Proceedings of the International Arid Lands Conference. [Oct. 8-15, 1978, Lubbock, Texas]. J. R. Goodin and D. K. Northington, eds. 724 p. International Center for Arid and Semi-Arid Land Studies, Texas Tech Univ., Lubbock.

Bailey, Robert G. 1976. Ecoregions of the United States [map]. USDA Forest Service, Intermountain Region, Ogden, Utah.

Bailey, Robert G. 1980. Descriptions of the ecoregions of the United States. U.S. Department of Agriculture, Miscellaneous Publication No. 1391. 77 p. Washington, D. C.

Bailey, Robert G., Robert D. Pfister, and Jan A. Henderson. 1978. Nature of land and resource classification - A review. Journal of Forestry 76: 650-655.

Baker, W. L. 1983. Alpine vegetation of Wheeler Peak, New Mexico, U.S.A.: Gradient analysis, classification, and biogeography. Arctic and Alpine Research 15:223-240.

Baldridge, W. S., Y. Bartov, and A. Kron. 1983. Geologic map of the Rio Grande Rift and southeastern Colorado Plateau, New Mexico, and Arizona. American Geophysical Union, Washington, D.C.

Barbour, M. G., J. H. Burk, and W. D. Pitts. 1980. Terrestrial plant ecology. $604 \mathrm{p}$. The Benjamin/Cummings Publ. Co., Inc., Menlo Park, Calif.

Barkman, Jan J. 1978. Synusial approaches to classification, p. 111-165. In: Classification of plant communities. Robert H. Whittaker, ed. 408 p. Dr. W. Junk bv Publishers, The Hague. 
Beavis, W. D., J. C. Owens, J. A. Ludwig, and E. W. Huddleston. 1982. Grassland communities of east-central New Mexico and density of the range caterpillar, Hemileuca oliviae (Lepidoptera: Saturniidae). The Southwestern Naturalist 27(3):335-343.

Boyd, Christine. 1984. An analysis of the vegetation of the MacMillan Pass region, Yukon: Collection of data and methods of analysis. p. 127-133. In Inventorying forest and other vegetation of the high latitude and high altitude regions. Proceedings of an International Symposium. Society of American Foresters Regional Technical Conference. [Fairbanks, Alaska, July 23-26, 1984]. 296 p. Vernon J. LaBau and Calvin L. Kerr, editors. Society of American Foresters, Bethesda, Maryland.

Brown, David E. (ed.). 1982. Biotic communities of the American Southwest-United States and Mexico. Desert Plants 4(1-4):1-342.

Brown, D. E. and C. H. Lowe. 1980. Biotic communities of the Southwest. USDA Forest Service General Technical Report RM-78, [map]. Rocky Mountain Forest and Range Experiment Station, Fort Collins, Colo.

Brown, D. E., C. H. Lowe, and C. P. Pase. 1979. A digitized classification system for the biotic communities of North America, with community (series) and association examples for the Southwest. Journal of the Arizona-Nevada Academy Science 14(1):1-16.

Buol, S. W., F. D. Hole, and R. J. McCracken. 1973. Soil genesis and classification. 360 p. The Iowa State University Press, Ames.

Burkham, D. E. 1966. Hydrology of Cornfield Wash area and effects of land-treatment practices, Sandoval County, New Mexico, 1951-60. USDI Geological Survey, Water Supply Paper No. 1831. Washington, D.C.

Cable, Dwight R. 1975. Range management in the chaparral type and its ecological basis: The status of our knowledge. USDA Forest Service Research Paper RM-155, 30 p. Rocky Mountain Forest and Range Experiment Station, Fort Collins, Colo.

Calkins, H. G. 1937. A report on the Cuba Valley. USDA Soil Conservation Service, Region 8, Regional Bulletin No. 36. Albuquerque, N. Mex.

Campbell, R. E. 1968. Production capabilities of some upper Rio Puerco soils of New Mexico. USDA Forest Service Research Note RM-108, 7 p. Rocky Mountain Forest and Range Experiment Station, Fort Collins, Colo.

Castetter, E. F. 1956. The vegetation of New Mexico. New Mexico Quarterly 26:257-288.

Clary, Warren P. 1975. Range management and its ecological basis in the ponderosa pine typé of Arizona: The status of our knowledge. USDA Forest Serivce Research Paper RM-158, 35 p. Rocky Mountain Forest and Range Experiment Station, Fort Collins, Colo.

Clements, Frederic E. 1916. Plant succession. Carnegie Institute Publ. 242. Washington, D. C.

Coffey, G. N. 1912. A study of the soils of the United States. USDA Bureau of Soil, Bulletin No. 85. 114 p. Washington, D.C.
Cruickshank, J. G. 1972. Soil geography. 256 p. David and Charles, Inc., North Pomfret, Vermont.

Daubenmire, R. 1966. Vegetation: Identification of typal communities. Science 151:291-298.

Daubenmire, Rexford. 1968. Plant communities: A textbook of plant synecology. 300 p. Harper and Row, Publishers, New York.

Daubenmire, Rexford. 1984. Viewpoint: Ecological site/range site/habitat type. Rangelands 6:263-264.

Dix, Ralph L. 1961. An application of the point-centered quarter method to the sampling of grassland vegetation. Journal of Range Management 14:63-69.

Donart, G. B., D. D. Sylvester, and W. C. Hickey. 1978. Potential natural vegetation-New Mexico. [map]. New Mexico Interagency Range Committee, Report No. 11. USDA Soil Conservation Service, Portland, Oreg.

Dortignac, Edward J. 1960. The Rio Puerco-past, present, and future. New Mexico Water Conference Proc. 5:45-51.

Driscoll, R. S., D. L. Merkel, D. L. Radloff, D. E. Snyder, and J. S. Hagihara. 1984. An ecological land classification framework for the United States. USDA Forest Service, Miscellaneous Publication No. 1439, 56 p. Washington, D.C.

DuRietz, G. E. 1930. Classification and nomenclature of vegetation. Svensk Bot. Tidskr. 24:489-503.

Dyer, D. P. 1978. An analysis of species dissimilarity using multiple environmental variables. Ecology 59(1):117-125.

Dyksterhuis, E. J. 1958. Range conservation based on sites and condition classes. Journal of Soil and Water Conservation 13:151-155.

Everitt, B. S. 1979. Unresolved problems in cluster analysis. Biometrics 35:169-181.

Finkl, Charles, W., Jnr. 1982. Introduction. p. 1-10. In: Soil Classification: Benchmark papers in soil science, vol. 1. Charles W. Finkl, Jnr., ed. 391 p. Hutchinson Ross Publishing Co., Stroudsburg, Penn.

Folks, J. J. and W. B. Stone. 1968. Soil survey: Cabezon area, New Mexico. 44 p. USDA Soil Conservation Service, Washington, D.C.

Francis, Richard E. 1978. Current rangeland inventory methods - Compatability toward an ecological base? p. 91-103. In: Integrated inventories of renewable natural resources: Proceedings of the workshop. [Tucson, Ariz., Jan. 8-12, 1978]. H. Gyde Lund et al., tech. coord. General Technical Report RM-55, 482 p. Rocky Mountain Forest and Range Experiment Station, Fort Collins, Colo.

Gleason, H. A. 1926. The individualistic concept of the plant association. Bulletin of the Torrey Botanical Club 53:7-26.

Goodall, David W. 1978. Numerical classification. p. 247-286. In: Classification of plant communities. Robert H. Whittaker, editor. 408 p. Dr. W. Junk bv Publishers, The Hague.

Greig-Smith, P. 1983 (3rd ed.). Quantitative plant ecology. 359 p. University of California Press, Berkeley.

Gross, F. A. and W. A. Dick-Peddie. 1979. A map of primeval vegetation in New Mexico. The Southwestern Naturalist 24:115-122. 
Hanson, Herbert C. 1962. Dictionary of ecology. 382 p. Philosophical Library. New York.

Hickey, Wayne C., Jr. and George Garcia. 1964. Range utilization patterns as affected by fencing and class of livestock. USDA Forest Service Research Note RM-21, 7 p. Rocky Mountain Forest and Range Experiment Station, Fort Collins, Colo.

Humphrey, R. R. 1947. Range forage evaluation by the range condition method. Journal of Forestry 45:10-16.

Huschle, G. and M. Hironaka. 1980. Classification and ordination of plant communities. Journal of Range Management 33:179-182.

Jameson, Donald A. 1970. Value of broom snakeweed as a range condition indicator. Journal of Range Management 23(4):302-304.

Langford, Arthur N. and Murray F. Buell. 1969. Integration, identity and stability in the plant association. p. 83-135. In: Advances in ecological research, Vol. 6. J. B. Cragg, editor. 236 p. Academic Press, New York.

Lowe, Charles H. and David E. Brown. 1982. Introduction. p. 8-16. In: Biotic communities of the American Southwest-United States and Mexico. David E. Brown, editor. Desert Plants 4(1-4):1-342.

MacArthur, Robert H. and John W. MacArthur. 1961. On bird species diversity. Ecology 42(3):594-598.

Marbut, C. F. 1922. Soil classification. American Association of Soil Survey Workers, 2nd Annual Report, Bulletin 3:24-32.

Margalef, D. R. 1958. Information theory in ecology. General Systems 3:36-71.

Martin, S. Clark. 1975. Ecology and management of southwestern semidesert grass-shrub ranges: The status of our knowledge. USDA Forest Service Research Paper RM-156, 39 p. Rocky Mountain Forest and Range Experiment Station, Fort Collins, Colo.

Martin, William C. and Charles R. Hutchins. 1980. A flora of New Mexico. 2591 p., 2 vols. J. Cramer, Hirschberg, Germany.

McDaniel, K. C., R. D. Pieper, and G. B. Donart. 1982. Grass response following thinning of broom snakeweed. Journal of Range Management 35(2):219-222.

McIntosh, Robert P. 1967. The continuum concept of vegetation. Botanical Review 33(2):130-187.

Meeker, Donald O., Jr. and Daniel L. Merkel. 1984. Climax theories and a recommendation for vegetation classification-a viewpoint. Journal of Range Management 37(5):427-430.

Moir, William H. 1967. The subalpine tall grass, Festuca thurberi community of Sierra Blanca, New Mexico. Southwestern Naturalist 12:321-328.

Moir, William H. 1979. Soil-vegetation patterns in the central Peloncillo Mountains, New Mexico. The American Midland Naturalist 102(2):317-331.

Moir, W. H and L. Hendzel (tech. coord.). 1983. Proceedings of the Workshop on Southwestern Habitat Types [April 6-8, 1983, Albuquerque, N. Mex.]. 110 p. USDA Forest Service, Southwestern Region, Albuquerque, N. Mex.
Morris, Meredith J. 1973. Estimating understory plant cover with rated microplots. USDA Forest Service Research Paper RM-104, 12 p. Rocky Mountain Forest and Range Experiment Station, Fort Collins, Colo.

Mueggler, W. F. and W. L. Stewart. 1980. Grassland and shrubland habitat types of western Montana. USDA Forest Service General Technical Report INT-66, 154 p. Intermountain Forest and Range Experiment Station, Ogden, Utah.

Mueller-Dombois, D. and H. Ellenberg. 1974. Aims and methods of vegetation ecology. 547 p. John Wiley and Sons, New York.

Muir, J. W. 1962. The general principles of classification with reference to soils. Journal of Soil Science 13:22-30.

Nickerson, M. F., G. E. Brink, and C. Feddema. 1976. Principal range plants of the central and southern Rocky Mountains: Names and symbols. USDA Forest Service General Technical Report RM-20, 121 p. Rocky Mountain Forest and Range Experiment Station, Fort Collins, Colo.

Numata, Makoto. 1979. Ecology of grasslands and bamboolands in the world. 299 p. Dr. W. Junk bv Publishers, The Hague.

Pase, C. P. 1981. Community structure analysis-a rapid, effective range condition estimator for semi-arid ranges. p. 425-430. In: Arid land resource inventories: Developing cost-efficient methods. [Nov. 30 - Dec. 6, 1980, LaPaz, Mexico]. H. G. Lund, et al. tech. coord. USDA Forest Service General Technical Report WO-28, 620 p. Washington, D.C.

Peet, R. K. 1974. The measurement of species diversity. Annual Review Ecological Systems 5:285-307.

Phillips, Edwin A. 1959. Methods of vegetation study. 107 p. Henry Holt and Company, Inc., Ann Arbor, Michigan.

Pielou, E. C. 1974. Population and community ecology. 424 p. Gordon and Breach Science Publishers, New York.

Pielou, E. C. 1975. Ecological diversity. 165 p. John Wiley and Sons, Inc., New York.

Pielou, E. C. 1977. Mathematical ecology. 385 p. John Wiley and Sons, Inc., New York.

Poore, M.E.D. 1962. The method of successive approximation in descriptive ecology. Advances in Ecological Research 1:35-68. Academic Press, New York.

Powell, D. S. 1982. A solution for resolving conflicts between land use and land cover inventories. p. 665-668. In: In-place resource inventories: Principles and practices. [August 9-14, 1981, Orono, Maine]. T. B. Braun, L. O. House IV, and H. G. Lund, eds., 1101 p. Society of American Foresters, Bethesda, Md.

Ramensky, L. G. 1926. Die Grundgesetzmassigkeiten im Aufbau der Vegetationsdecke. (Abstr. from Vestn. opytn. Dela, Voronezh 1924: $37-73$, as cited by Whittaker 1962).

Renner, F. G. 1948. Range condition: A new approach to the management of natural grazing lands. Proceedings of the Inter-American Conference on Conservation of Renewable Natural Resources. U.S. State Department Publication 3382:527-535. Washington, D.C. 
Reppert, Jack N. and Richard E. Francis. 1973. Interpretation of trend in range condition from 3-step data. USDA Forest Service Research Paper RM-103, 15 p. Rocky Mountain Forest and Range Experiment Station, Fort Collins, Colo.

Romesburg, H. C. 1984. Cluster analysis for researchers. 334 p. Lifetime Learning Publications, Belmont, Calif. Schelling, J. 1970. Soil genesis, soil classification and soil survey. Geoderma 4:165-193.

Schlatterer, Edward F. 1983. Forest ecosystem classification and interpretation for management of multiple uses in forest and rangeland environments. p. 1-4. In: Proceedings of the Workshop on Southwestern Habitat Types. [April 6-8, 1983, Albuquerque, N. Mex.]. W. H. Moir and L. Hendzel, tech. coord. 110 p. USDA Forest Service, Southwestern Region, Albuquerque, N. Mex.

Shiflet, T. N. 1973. Range sites and soils in the United States. p. 26-33. In: Arid shrublands, Proceedings of the 3rd Workshop of the U.S.-Australia Rangelands Panel. [Mar. 26 - Apr. 5, 1973, Tucson, Arizona]. D. N. Hyder, ed. 148 p. Society for Range Management, Denver, Colo.

Shimwell, D. M. 1972. The description and classification of vegetation. 322 p. University of Washington Press, Seattle.

Simonson, R. W. 1962. Soil classification in the United States. Science 137:1024-1034.

Sneath, P. H. A. and R. R. Sokal. 1973. Numerical taxonomy. 573 p. W. H. Freeman and Co., San Francisco.

Soil Survey Staff. 1960. Soil classification: A comprehensive system, 7th approximation. 503 p. USDA Soil Conservation Service, Washington, D.C.

Soil Survey Staff. 1975. Soil taxonomy: A basic system of soil classification for making and interpreting soil surveys. U.S. Department of Agriculture Handbook No. 436, 754 p. Washington, D.C.

Springfield, H. W. 1976. Characteristics and management of southwestern pinyon-juniper ranges: The status of our knowledge. USDA Forest Service Research Paper RM-160, 32 p. Rocky Mountain Forest and Range Experiment Station, Fort Collins, Colo.

Stewart, W. L. and W. J. Hann. 1983. Classification of shrub steppe habitat in the northern Rocky Mountains. p. 11-20. In: Proceedings of the workshop on southwestern habitat types. [April 6-8, 1983, Albuquerque, N. Mex.]. W. H. Moir and Leonard Hendzel, tech. coord. 110 p. USDA Forest Service, Southwestern Region, Albuquerque, N. Mex.
Tansley, A. G. 1920. The classification of vegetation and the concept of development. Journal of Ecology 8: 118-149.

Tiedeman, James A. and Charles Terwilliger, Jr. 1978. Phyto-edaphic classification of the Piceance Basin. Range Science Department, Science Series No. 31, 265 p. Colorado State University, Fort Collins, Colo.

Tuxen, R. 1956. Die heutige potentielle naturliche Vegetation als Gegenstand der Vegetationskartierung. Stolzenau/Weser. Angewandte Pflanzensoziologie 13:5-42. (As cited by Küchler 1964).

Ueckert, D. N. 1979. Broom snakeweed: Effect on shortgrass forage production and soil water depletion. Journal of Range Management 32(3):216-220.

United Nations Educational, Scientific and Cultural Organization (UNESCO). 1973. International classification and mapping of vegetation, Series 6, Ecology and Conservation. 93 p. UNESCO, Paris, France.

Vincent, Dwain. 1984. Range trend in the Cabezon area. Rangelands 6(3):120-122.

Ward, J. H., Jr. 1963. Hierarchical grouping to optimize an objective function. Journal of the American Statistical Association 58(301):236-244.

Westhoff, Victor and Eddy van der Maarel. 1978. The Braun-Blanquet approach. p. 287-378. In: Classification of plant communities. Robert $\mathrm{H}$. Whittaker, ed. 408 p. Dr. W. Junk bv Publishers, The Hague.

Whittaker, Robert H. 1962. Classification of natural communities. Botanical Review 28(1):1-239.

Whittaker, Robert H. 1975 (2nd ed.). Communities and ecosystems. 383 p. Macmillan Publishing Co., Inc., New York.

Whittaker, Robert H. 1978. Approaches to classifying vegetation. p. 1-31. In: Classification of plant communities. Robert H. Whittaker, ed. 408 p. Dr. W. Junk bv Publishers, The Hague.

Whittaker, R. H., S. W. Buol, W. A. Niering, and Y. H. Havens. 1968. A soil and vegetation pattern in the Santa Catalina Mountains, Arizona. Soil Science 105:440-450.

Wishart, D. 1981. CLUSTAN user manual. Program Library Unit, Edinburg Univ., Edinburg, Scotland.

York, J. C. and W. A. Dick-Peddie. 1969. Vegetation changes in southern New Mexico during the past hundred years. p. 157-166. In: Arid lands in perspective. W. O. McGinnies and B. J. Goldman, eds. 421 p. University of Arizona Press, Tucson. 
Table 6.-Vegetation and soil surface characteristics for plant community 1 (p.c.1).

Mean'

COMMUNITY 1 : PIPO/CARE-BOgr

SITES $\quad 80 \quad 101 \quad 102$

$\begin{array}{lllllllllllll}\text { No. Sites } & \text { No. Trans. } & \frac{C}{3} & \frac{\mathrm{C}}{33.1} & \frac{\mathrm{TC}}{26.4} & \frac{\mathrm{SC}}{3.3} & \frac{\mathrm{HC}}{3.4} & \frac{\mathrm{L}}{21.7} & \frac{\mathrm{R}}{0.7} & \frac{\mathrm{BS}^{2}}{74.2} & \frac{D}{11.9} & \frac{d}{2.03} & \frac{\mathrm{SR}}{34}\end{array}$

PERCENT COVER DENSITY PERCENT FREQUENCY

IMPORTANCE VALUE

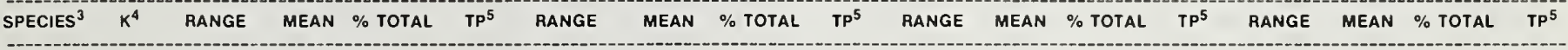

PIPO $\quad 3 \quad .587-.699 \quad .651 \quad(21.7)$

$\begin{array}{lll}3 & .587-.699 \\ \text { CARE } & 3 & 413-.536\end{array}$

POFE

BOGR

PIED

$.357-.606 \quad .450 \quad(15.0)$

$0.000-.578$

$.231-.297$

$\begin{array}{ll}.450 & (15.0) \\ .286 & |9.5\rangle\end{array}$

.261 ( 8.7)

QUGA $\quad 3 \quad .010-.238$

$\begin{array}{ll}4.0) & 83.7\end{array}$

$16.4-26.6$

20.7

(62.5)

$(1.2\rangle$
$(3.0)$

$.5-1.3$

$0.0-.3$

$.5-1.0$

$.5-11.2$

$0.0-.4$

$\begin{array}{lll}1.0 & (3.0)\end{array}$

$\begin{array}{ll}.2 & \left(\begin{array}{r}.6 \\ .7\end{array}\right) \\ .9 & (2.2)\end{array}$

$4.9 \quad(14.9)$

ANCI

HYME2

THPI

YUGL

ERIO1

AGSM

ANTE

JUOS

CEMO

ARLO

SIHY

LUPI

BLTR

ARAB

ARFR

SPHA

CHNA

SPCR

KOCR

GERA

CAIN2

SPCO

PSME

FEAR

JUMO

FERU1

\begin{tabular}{|c|c|}
\hline \multicolumn{2}{|r|}{.078} \\
\hline & .076 \\
\hline & .072 \\
\hline $.004-.056$ & .029 \\
\hline \multirow[t]{2}{*}{$0.000-.036$} & .021 \\
\hline & .021 \\
\hline $0.000-.033$ & .019 \\
\hline \multirow[t]{3}{*}{$.004-.045$} & .019 \\
\hline & .018 \\
\hline & .017 \\
\hline \multirow[t]{9}{*}{$.015-.019$} & .017 \\
\hline & .015 \\
\hline & .012 \\
\hline & .011 \\
\hline & .010 \\
\hline & .007 \\
\hline & .006 \\
\hline & .005 \\
\hline & .005 \\
\hline \multirow[t]{8}{*}{$0.000-.014$} & .005 \\
\hline & .005 \\
\hline & .005 \\
\hline & .005 \\
\hline & .005 \\
\hline & .003 \\
\hline & .001 \\
\hline & 3.000 \\
\hline
\end{tabular}

$(2.6)$
$(2.5)$

(2.5)

$(2.4)$
$(1.0)$

(.7)

( .7)

$\left(\begin{array}{ll}1 \\ ( & 6)\end{array}\right.$

$\left(\begin{array}{l}6) \\ (.6)\end{array}\right.$

( .6)

$($. .6)

( .5)

$\left(\begin{array}{l}.5) \\ (.4)\end{array}\right.$

(.4)

( .3)

(. 2)

( . .2)

(.2)

(.2)

(.2)

(.)

$(.2)$

$\left(\begin{array}{r}.1) \\ (0.0)\end{array}\right.$

$\begin{array}{lll}2.9 & (8.8) & 93.8\end{array}$

$\begin{array}{rr}0-.1 & .1 \\ 2.5-2.9 & 2.8\end{array}$

(23

$\begin{array}{rrr}2.0-10.0 & 5.0 & (2.2)\end{array}$

$30.0-57.0 \quad 45.7 \quad(19.7)$

$36.0-78.0 \quad 57.0$

$0.0-60.0 \quad 32.3 \quad(14.0)$

$\begin{array}{rrr}0.0-60.0 & 32.3 & (14.0) \\ 17.0-27.0 & 20.7 & (8.9)\end{array}$

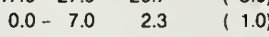

$0.0-20.0 \quad 13.3 \quad(5.8)$

$\begin{array}{llllllll}0.0-.4 & .2 & (1.3) & 87.3 & 0.0-13.0 & 5.7 & (2.4) & 78.6\end{array}$

( . 2)

$\left(\begin{array}{ll}1 \\ (1)\end{array}\right.$

$(.7)$

$\left(\begin{array}{ll}(7) \\ (\text {. } 17\end{array}\right.$

$\left(\begin{array}{lll}1 \\ ( & .0\end{array}\right)$

$(0.0)$

$\left(\begin{array}{l}0.0) \\ (2.0)\end{array}\right.$

$\left(\begin{array}{l}2.0) \\ (1.3)\end{array}\right.$

$0.0-0.0$

$0.0-0.0$
$2-1.6$

$\begin{array}{rrr}0.0 & (0.0) \\ 0-1 & 0.0\end{array}$

$\left(\begin{array}{ll}(2) \\ (\quad)\end{array}\right.$

$(0.0)$

$\left(\begin{array}{ll}1 & 1\end{array}\right)$

$(0.0)$
$(0.0)$

$\left(\begin{array}{l}0.0) \\ (0.0)\end{array}\right.$

$(0.0)$

$(0.0)$

$(0.0)$

$0.0-.0$

$(0.0)$
$(0.0)$

$\left(\begin{array}{l}0.0) \\ (0.0)\end{array}\right.$

$(0.0)$

$(0.0)$

$(0.0)$

$(.3)$
$\left(\begin{array}{l}1 \\ \text { (.) }\end{array}\right)$

$0.0-.1$
$0.0-.1$
$0.0-.3$
$0.0-0.0$

$(1.8)$

$0.0-13.0$

(3.2)

$\left\{\begin{array}{l}1.8\rangle \\ (2.9)\end{array}\right.$

(2.1)

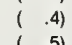

$\left(\begin{array}{ll}(.5) \\ (\text { ) }\end{array}\right.$

$\left(\begin{array}{ll}( \\ (1.3)\end{array}\right.$

$(1.3)$
$(0.0)$

$(0.0)$
$(0.0)$

$\left(\begin{array}{ll}(\quad 6) \\ (\quad 2)\end{array}\right.$

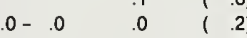

( .8$)$

$\left(\begin{array}{ll}1 \\ ( & .1\end{array}\right.$

$\begin{array}{ll}( & .27 \\ ( & 3)\end{array}$

$\left.\begin{array}{ll}( & .3 \\ ( & .2\end{array}\right)$

$\left(\begin{array}{ll}1 \\ (.1)\end{array}\right.$

$\begin{array}{ll}( & .3) \\ ( & .1)\end{array}$

$\left(\begin{array}{ll}1 \\ ( \\ ( & 1\end{array}\right)$

$0.0-.0$

$\left(\begin{array}{ll}1 \\ ( \\ (.1)\end{array}\right.$

$(.1)$
$($.1)

$\left(\begin{array}{ll}.1 \\ (\end{array}\right)$

$.1)$
$(.1)$

$(0.0)$
$(0.0)$

$\begin{array}{lll} & 7.3 & (3.2) \\ & 4.0 & (1.7) \\ 0.0-7.0 & 4.7 & (2.0)\end{array}$

$\begin{array}{lll}0.0-7.0 & 3.7 & (1.6) \\ 0.0-7.0 & 4.7 & (2.0)\end{array}$

$(2.0)$

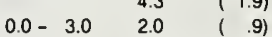

$\begin{array}{lll}0.0-0.0 & 0.0 & (0.0)\end{array}$

$\begin{array}{ll}0.0 & (0.0)\end{array}$

$2.0-3.0 \quad 2.7 \quad\left(\begin{array}{rl}.6) \\ 1.2)\end{array}\right.$

( 1.0$)$

$($. 6)

$(6)$

( 1.0$)$

$\left(\begin{array}{ll}1.0 \\ (\quad 3)\end{array}\right.$

( .4)

( . 3)

$(.3)$

$0.0-3.0$

( . .4)

$(.3)$

(. .4)

$(.4)$

$($ (.4)

$(0.0)$

33.1

11.9

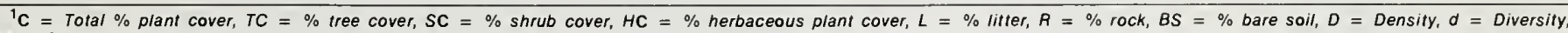
$S R=$ Species richness.

${ }^{2} B S=100-(H C+L+R)$.

${ }^{3}$ Plant species symbol (see Appendix B for full nomenclature).

${ }^{4} \mathrm{~K}=$ Constancy.

${ }^{5} T P=$ Total percent for species with $I V \geqslant 0.1$. 
Table 7. - Vegetation and soil surface characteristics for plant community 2 (p.c.2)

COMMUNITY 2: Pied.Pipo/Bogr.CARE SITES $\quad 36$
Mean

\begin{tabular}{|c|c|c|c|c|c|c|c|c|c|c|c|c|c|c|c|c|c|}
\hline \multirow[b]{2}{*}{ SPECIES $^{3}$} & \multicolumn{5}{|c|}{ IMPORTANCE VALUE } & \multicolumn{4}{|c|}{ PERCENT COVER } & \multicolumn{4}{|c|}{ DENSITY } & \multicolumn{4}{|c|}{ PERCENT FREQUENCY } \\
\hline & $K^{4}$ & RANGE & MEAN & $\%$ TOTAL & $T P^{5}$ & RANGE & MEAN & $\%$ TOTAL & $T P^{5}$ & RANGE & MEAN & $\%$ TOTAL & $T P^{5}$ & RANGE & MEAN & $\%$ TOTAL & $T P^{5}$ \\
\hline BOGR & 1 & & .761 & $(25.8)$ & & & 1.5 & $(5.8)$ & & & 7.4 & (51.2) & & & 50.0 & (18.9) & \\
\hline $\mathrm{CHVI2}$ & 1 & & .563 & $(19.1)$ & & & 2.3 & $(9.0)$ & & & 2.6 & $(17.6)$ & & & 91.0 & (34.3) & \\
\hline PIED & 1 & & .331 & $(11.2)$ & & & 8.3 & (33.1) & & & 0.0 & $(0.0)$ & & & 0.0 & $(0.0)$ & \\
\hline PIPO & 1 & & .278 & $(9.4)$ & & & 7.0 & (27.8) & & & 0.0 & $(0.0)$ & & & 0.0 & $(0.0)$ & \\
\hline CARE & 1 & & .252 & ( 8.5$)$ & & & .3 & $(1.2)$ & & & 2.0 & (13.8) & & & 27.0 & $(10.2)$ & \\
\hline LEER & 1 & & .122 & ( 4.1$)$ & & & .1 & ( . .3) & & & .6 & $(4.4)$ & & & 20.0 & $(7.5)$ & \\
\hline SPOR & 1 & & .103 & ( 3.5$)$ & 81.6 & & .3 & $(1.2)$ & 78.4 & & .4 & $(2.8)$ & 89.8 & & 17.0 & $(6.4)$ & 77.3 \\
\hline ARTR & 1 & & .090 & $(3.0)$ & & & 1.9 & $(7.6)$ & & & .0 & $(.2)$ & & & 3.0 & $(1.1)$ & \\
\hline THPI & 1 & & .080 & $(2.7)$ & & & .0 & ( .1) & & & 8 & ( 5.3$)$ & & & 7.0 & ( 2.6) & \\
\hline JUMO & 1 & & .054 & $(1.8)$ & & & 1.4 & $(5.4)$ & & & 0.0 & $(0.0)$ & & & 0.0 & $(0.0)$ & \\
\hline POLO & 1 & & .052 & $(1.8)$ & & & .1 & ( .3) & & & .2 & $(1.2)$ & & & 10.0 & (3.8) & \\
\hline KOCA & 1 & & .038 & $(1.3)$ & & & .2 & $(8)$ & & & .1 & ( . .5) & & & 7.0 & ( 2.6$)$ & \\
\hline ERIO1 & 1 & & .037 & $(1.3)$ & & & .6 & ( 2.3$)$ & & & .0 & ( . .2) & & & 3.0 & (1.1) & \\
\hline SEDU & 1 & & .036 & $(1.2)$ & & & .1 & $(.4)$ & & & .1 & $(.7)$ & & & 7.0 & $(2.6)$ & \\
\hline OENO & 1 & & .034 & $(1.2)$ & & & .0 & (.1) & & & .1 & $(.7)$ & & & 7.0 & $(2.6)$ & \\
\hline OUGA & 1 & & .033 & $(1.1)$ & & & .8 & ( 3.3$)$ & & & 0.0 & $(0.0)$ & & & 0.0 & $(0.0)$ & \\
\hline ARAB & 1 & & .030 & $(1.0)$ & & & 0.0 & $(0.0)$ & & & .1 & ( . .5) & & & 7.0 & $(2.6)$ & \\
\hline $\mathrm{MACH}$ & 1 & & .017 & $(.6)$ & & & 0.0 & $(0.0)$ & & & .1 & (. .5) & & & 3.0 & $\langle 1.1\rangle$ & \\
\hline MUHL & 1 & & .015 & ( . .5) & & & 0.0 & $(0.0)$ & & & .0 & ( . .2) & & & 3.0 & (1.1) & \\
\hline GUSA & 1 & & .015 & ( .5) & & & 0.0 & $(0.0)$ & & & .0 & (. .2) & & & 3.0 & ( 1.1$)$ & \\
\hline ERLA & 1 & & .011 & (. .4) & & & .3 & $(1.1)$ & & & 0.0 & $(0.0)$ & & & 0.0 & $(0.0)$ & \\
\hline SENE & 1 & & .001 & $(0.0)$ & & & .0 & $(.1)$ & & & 0.0 & $(0.0)$ & & & 0.0 & $(0.0)$ & \\
\hline HIJA & 1 & & .001 & $(0.0)$ & & & .0 & ( .1) & & & 0.0 & $(0.0)$ & & & 0.0 & $(0.0)$ & \\
\hline & & & $\overline{2.954}$ & & & & 25.2 & & & & 14.5 & & & & & & \\
\hline
\end{tabular}

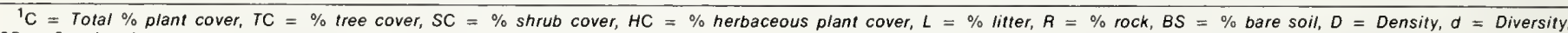
$S R=$ Species richness.

${ }^{3}$ Plant species symbol (see Appendix B for full nomenclature).

${ }^{4} \mathrm{~K}=$ Constancy.

${ }^{5} T P=$ Total percent for species with $I V \geqslant 0.1$.

Table 8. - Vegetation and soil surface characteristics for plant community 3 (p.c.3).

Mean $^{1}$

COMMUNITY 3 : Pied/Bogr.ERIO

SITES $\quad 20$ $\begin{array}{lllllllllllll}\text { No. Sites } & \text { No. Trans. } & \frac{\mathrm{C}}{2} & \frac{\mathrm{TC}}{8.6} & \frac{\mathrm{SC}}{2.3} & \frac{\mathrm{HC}}{0.5} & \frac{\mathrm{L}}{5.8} & \frac{\mathrm{R}}{1.6} & \frac{\mathrm{BS}^{2}}{22.6} & \frac{\mathrm{d}}{70.0} & \frac{\mathrm{d}}{5.6} & \frac{\mathrm{S}}{1.95} & \frac{\mathrm{SR}}{16}\end{array}$

DENSITY

PERCENT FREQUENCY

\begin{tabular}{|c|c|c|c|c|c|c|c|c|c|c|c|c|c|c|c|c|c|}
\hline SPECIES ${ }^{3}$ & $k^{4}$ & RANGE & MEAN & $\%$ TOTAL & $T P^{5}$ & RANGE & MEAN & $\%$ TOTAL & $T P^{5}$ & RANGE & MEAN & $\%$ TOTAL & $T P^{5}$ & RANGE & MEAN & $\%$ TOTAL & $T P^{5}$ \\
\hline ERLE & 1 & & .720 & $(24.0)$ & & & 3.3 & $(38.4)$ & & & .9 & (15.2) & & & 35.0 & $(18.4)$ & \\
\hline ERJA & 1 & & .585 & (19.5) & & & .3 & (3.5) & & & 1.9 & (33.9) & & & 40.0 & (21.1) & \\
\hline BOGR & 1 & & .314 & (10.5) & & & .3 & ( 2.9) & & & 1.3 & (23.2) & & & 10.0 & ( 5.3$)$ & \\
\hline PIED & 1 & & .233 & $(7.8)$ & & & 2.0 & (23.3) & & & 0.0 & $(0.0)$ & & & 0.0 & $(0.0)$ & \\
\hline ERIO1 & 1 & & .167 & $(5.6)$ & & & .2 & (1.7) & & & .3 & $(4.5)$ & & & 20.0 & (10.5) & \\
\hline GUSA & 1 & & .164 & (5.5) & & & .5 & $(5.8)$ & & & .2 & ( 2.7$)$ & & & 15.0 & ( 7.9$)$ & \\
\hline HIJA & 1 & & .147 & ( 4.9$)$ & & & .1 & ( . .6) & & & .4 & ( 6.3$)$ & & & 15.0 & ( 7.9$)$ & \\
\hline ORHY & 1 & & .120 & $(4.0)$ & & & .4 & $(4.1)$ & & & .2 & ( 2.7$)$ & & & 10.0 & ( 5.3$)$ & \\
\hline HYFI & 1 & & .106 & ( 3.5$)$ & 85.3 & & .2 & $(1.7)$ & 82.0 & & .2 & $(3.6)$ & 92.2 & & 10.0 & ( 5.3$)$ & 81.7 \\
\hline UNKF & 1 & & .079 & $(2.6)$ & & & 0.0 & $(0.0)$ & & & .2 & ( 2.7$)$ & & & 10.0 & ( 5.3$)$ & \\
\hline TOIN & 1 & & .079 & ( 2.6) & & & 0.0 & $(0.0)$ & & & .2 & ( 2.7$)$ & & & 10.0 & ( 5.3$)$ & \\
\hline MUHL & 1 & & .070 & (2.3) & & & 6 & $(7.0)$ & & & 0.0 & $(0.0)$ & & & 0.0 & $(0.0)$ & \\
\hline ARBI1 & 1 & & .058 & $(1.9)$ & & & .5 & $(5.8)$ & & & 0.0 & $(0.0)$ & & & 0.0 & $(0.0)$ & \\
\hline MENT1 & 1 & & .053 & $(1.8)$ & & & .2 & $(1.7)$ & & & .1 & ( .9$)$ & & & 5.0 & ( 2.6) & \\
\hline YUGL & 1 & & .035 & $(1.2)$ & & & 0.0 & $(0.0)$ & & & .1 & ( .9) & & & 5.0 & $(2.6)$ & \\
\hline CRFU & 1 & & .035 & (1.2) & & & 0.0 & $(0.0)$ & & & .1 & ( . .9) & & & 5.0 & ( 2.6$)$ & \\
\hline JUMO & 1 & & .029 & $(1.0)$ & & & .3 & ( 2.9) & & & 0.0 & $(0.0)$ & & & 0.0 & $(0.0)$ & \\
\hline MIMU & 1 & & .006 & (. .2) & & & .1 & ( .6) & & & 0.0 & $(0.0)$ & & & 0.0 & $(0.0)$ & \\
\hline & & & 3.000 & & & & 8.6 & & & & 5.6 & & & & & & \\
\hline
\end{tabular}

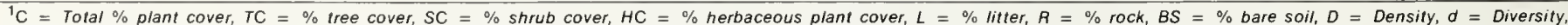
$S R=$ Species richness.

${ }_{3}^{3}$ Plant species symbol (see Appendix B for full nomenclature)

${ }^{4} K=$ Constancy.

${ }^{5} T P=$ Total percent for species with $I V \geqslant 0.1$. 
Table 9.-Vegetation and soil surface characteristics for plant community 4 (p.c.4).

Mean $^{1}$

COMMUNITY 4 : Pied.JumolOppolBogr

SITES $\quad 91$

91

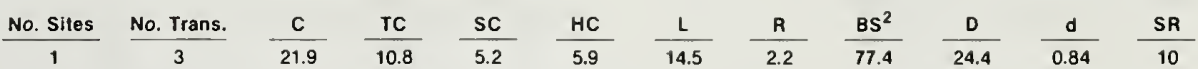

IMPORTANCE VALUE

PERCENT COVER DENSITY

PERCENT FREQUENCY

\begin{tabular}{|c|c|c|c|c|c|c|c|c|c|c|c|c|c|c|c|c|c|}
\hline SPECIES $^{3}$ & $k^{4}$ & RANGE & MEAN & $\%$ TOTAL & $T P^{5}$ & RANGE & MEAN & $\%$ TOTAL & $T P^{5}$ & RANGE & MEAN & $\%$ TOTAL & $T P^{5}$ & RANGE & MEAN & \% TOTAL & $T P^{5}$ \\
\hline BOGR & 1 & & 1.371 & (45.7) & & & 5.0 & (23.0) & & & 18.3 & (75.1) & & & 77.0 & $(38.5)$ & \\
\hline OPPO & 1 & & 650 & (21.7) & & & 3.2 & (14.7) & & & 4.0 & (16.4) & & & 67.0 & (33.5) & \\
\hline JUMO & 1 & & 298 & (9.9) & & & 6.5 & (29.8) & & & 0.0 & $(0.0)$ & & & 0.0 & $(0.0)$ & \\
\hline PIED & 1 & & .196 & ( 6.5) & & & 4.3 & (19.6) & & & 0.0 & $(0.0)$ & & & 0.0 & $(0.0)$ & \\
\hline GUSA & 1 & & .158 & ( 5.3$)$ & & & .3 & ( 1.2$)$ & & & .7 & ( 2.7 ) & & & 24.0 & $(12.0)$ & \\
\hline HIJA & 1 & & .121 & $(4.0)$ & 93.1 & & .5 & ( 2.4) & 90.9 & & .7 & ( 2.9 ) & 97.1 & & 14.0 & $(7.0)$ & 91.0 \\
\hline ARTR & 1 & & .085 & ( 2.8$)$ & & & 1.0 & $(4.7)$ & & & .1 & ( .4) & & & 7.0 & ( 3.5$)$ & \\
\hline SIHY & 1 & & .067 & ( 2.2$)$ & & & .3 & $(1.2)$ & & & .5 & ( 2.0$)$ & & & 7.0 & ( 3.5$)$ & \\
\hline YUGL & 1 & & .051 & ( 1.7$)$ & & & .7 & ( 3.0$)$ & & & .1 & ( . .4) & & & 4.0 & ( 2.0$)$ & \\
\hline SELO & 1 & & .003 & $(.1)$ & & & .1 & $(.3)$ & & & 0.0 & $(0.0)$ & & & 0.0 & $(0.0)$ & \\
\hline & & & 3.000 & & & & 21.9 & & & & 24.4 & & & & & & \\
\hline
\end{tabular}

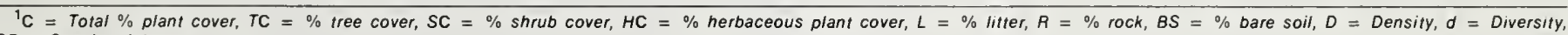
$S R=$ Species richness.

3 Plant species symbol (see Appendix B for full nomenclature).

${ }^{4} \mathrm{~K}=$ Constancy.

${ }^{5}{ }_{T P}=$ Cotal percent for species with $I V \geqslant 0.1$.

Table 10.-Vegetation and soil surface characteristics for plant community 5 (p.c.5).

COMMUNITY 5 : Pied/Quga/Hija-Spne SITES $\quad 96$
Mean ${ }^{1}$

$\begin{array}{llllllllllll}\text { No. Sites } & \text { No. Trans. } & \frac{C}{2} & \frac{\mathrm{TC}}{5.1} & \frac{\mathrm{SC}}{2.4} & \frac{\mathrm{HC}}{1.7} & \frac{\mathrm{L}}{3.3} & \frac{\mathrm{R}}{0} & \frac{\mathrm{BS}^{2}}{95.0} & \frac{\mathrm{D}}{3.4} & \frac{\mathrm{d}}{1.27} & \frac{\mathrm{SR}}{13}\end{array}$

IMPORTANCE VALUE

PERCENT COVER

DENSITY

PERCENT FREQUENCY

\begin{tabular}{|c|c|c|c|c|c|c|c|c|c|c|c|c|c|c|c|c|c|}
\hline SPECIES $^{3}$ & $K^{4}$ & RANGE & MEAN & $\%$ TOTAL & $T P^{5}$ & RANGE & MEAN & $\%$ TOTAL & $T P^{5}$ & RANGE & MEAN & $\%$ TOTAL & $T P^{5}$ & RANGE & MEAN & $\%$ TOTAL & $T P^{5}$ \\
\hline HIJA & 1 & & 1.143 & (38.1) & & & 6 & (11.8) & & & 2.0 & $(59.7)$ & & & 45.0 & (42.9) & \\
\hline SPNE1 & 1 & & 411 & (13.7) & & & .2 & ( 2.9) & & & .8 & (23.9) & & & 15.0 & (14.3) & \\
\hline QUGA & 1 & & .353 & (11.8) & & & 1.8 & (35.3) & & & 0.0 & $(0.0)$ & & & 0.0 & $(0.0)$ & \\
\hline PIED & 1 & & .196 & ( 6.5) & & & 1.0 & (19.6) & & & 0.0 & $(0.0)$ & & & 0.0 & $(0.0)$ & \\
\hline HYFI & 1 & & .151 & $(5.0)$ & & & .5 & ( 8.8 ) & & & .1 & ( 1.5$)$ & & & 5.0 & ( 4.8$)$ & \\
\hline EPTO & 1 & & .146 & ( 4.9$)$ & & & .4 & $(6.9)$ & & & .1 & $(3.0)$ & & & 5.0 & ( 4.8$)$ & \\
\hline CHGR & 1 & & .140 & ( 4.7) & & & 0.0 & $(0.0)$ & & & .2 & ( 4.5$)$ & & & 10.0 & (9.5) & \\
\hline GUSA & 1 & & .118 & ( 3.9$)$ & 88.6 & & .6 & (11.8) & 97.1 & & 0.0 & $(0.0)$ & 92.6 & & 0.0 & $(0.0)$ & 76.3 \\
\hline UNKF & 1 & & .092 & (3.1) & & & .2 & ( 2.9) & & & .1 & ( 1.5$)$ & & & 5.0 & ( 4.8$)$ & \\
\hline ORHY & 1 & & .063 & ( 2.1$)$ & & & 0.0 & $(0.0)$ & & & .1 & $(1.5)$ & & & 5.0 & ( 4.8$)$ & \\
\hline MENT1 & 1 & & .063 & (2.1) & & & 0.0 & $(0.0)$ & & & .1 & ( 1.5$)$ & & & 5.0 & ( 4.8) & \\
\hline CRJA & 1 & & .063 & ( 2.1$)$ & & & 0.0 & $(0.0)$ & & & .1 & ( 1.5$)$ & & & 5.0 & ( 4.8$)$ & \\
\hline \multirow[t]{2}{*}{ ANCI } & 1 & & .063 & (2.1) & & & 0.0 & $(0.0)$ & & & .1 & ( 1.5$)$ & & & 5.0 & $(4.8)$ & \\
\hline & & & 3.002 & & & & 5.1 & & & & 3.4 & & & & & & \\
\hline
\end{tabular}

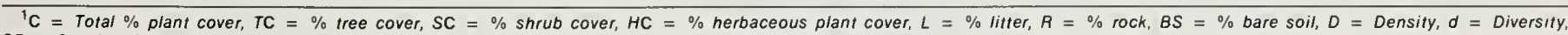
$S R=$ Species richness.

3 Plant species symbol (see Appendix B for full nomenclature).

${ }_{5}^{4} K=$ Constancy.

${ }^{5} T P=$ Total percent for species with $I V \geqslant 0.1$. 
Table 11.-Vegetation and soil surface characteristics for plant community 6 (p.c.6).

COMMUNITY 6 : Jumo/Gusa/Bogr.Hija

$\begin{array}{lllll}\text { SITES } & 103 & 104 & 106 & 108\end{array}$

Mean ${ }^{1}$

\begin{tabular}{|c|c|c|c|c|c|c|c|c|c|c|c|c|c|c|c|c|c|}
\hline \multirow[b]{2}{*}{ SPECIES $^{3}$} & \multirow[b]{2}{*}{$k^{4}$} & \multicolumn{4}{|c|}{ IMPORTANCE VALUE } & \multicolumn{4}{|c|}{ PERCENT COVER } & \multicolumn{4}{|c|}{ DENSITY } & \multicolumn{4}{|c|}{ PERCENT FREQUENCY } \\
\hline & & RANGE & MEAN & $\%$ TOTAL & $T P^{5}$ & RANGE & MEAN & $\%$ TOTAL & $T P^{5}$ & RANGE & MEAN & $\%$ TOTAL & $T P^{5}$ & RANGE & MEAN & $\%$ TOTAL & $T P^{5}$ \\
\hline BOGR & 4 & $.377-.858$ & .552 & $(18.4)$ & & $.7-5.1$ & 2.1 & $(15.2)$ & & $2.2-20.8$ & 8.0 & $(35.2)$ & & $18.0-80.0$ & 36.0 & $(14.0)$ & \\
\hline HIJA & 4 & $.234-.618$ & .467 & $\langle 15.5\rangle$ & & $.6-1.4$ & 1.0 & $(7.1)$ & & $2.5-5.3$ & 4.2 & $(18.7)$ & & $32.0-53.0$ & 39.3 & (15.3) & \\
\hline GUSA & 4 & $.221-.385$ & .328 & (10.9) & & $.1-1.6$ & .9 & (6.8) & & $.5-\quad .7$ & .6 & (2.4) & & $32.0-37.0$ & 33.8 & (13.1) & \\
\hline STNE & 4 & $.037-.498$ & .274 & (9.1) & & $.0-4.2$ & 1.5 & (10.6) & & $.2-7.0$ & 2.9 & (12.6) & & $4.0-70.0$ & 32.0 & (12.5) & \\
\hline ARLO1 & 4 & $.062-.350$ & .201 & $(6.7)$ & & $.5-1.5$ & .9 & $(6.2)$ & & $.2-2.6$ & 1.1 & $(5.0)$ & & $7.0-32.0$ & 16.3 & (6.3) & \\
\hline JUMO & 4 & $.127-.247$ & .193 & (6.4) & & $1.7-3.7$ & 2.7 & (19.2) & & $0.0-\quad .0$ & .0 & $(0.0)$ & & $0.0-3.0$ & .8 & ( . .3) & \\
\hline BOER1 & 2 & $0.000-.261$ & .112 & $(3.7)$ & 70.7 & $0.0-1.6$ & .5 & (3.3) & 68.4 & $0.0-4.4$ & 1.3 & $(5.8)$ & 79.7 & $0.0-43.0$ & 13.3 & $(5.2)$ & 66.7 \\
\hline BOCU & 4 & $.034-.180$ & .099 & ( 3.3$)$ & & $.2-.6$ & .3 & $(2.4)$ & & $.0-2.2$ & 1.0 & $(4.6)$ & & $2.0-18.0$ & 7.3 & ( 2.8) & \\
\hline MUTH & 3 & $0.000-.123$ & .081 & (2.7) & & $0.0-.5$ & .2 & ( 1.7$)$ & & $0.0-3.2$ & 1.1 & $(5.0)$ & & $0.0-10.0$ & 5.5 & $(2,1)$ & \\
\hline UNKF & 2 & $0.000-.300$ & .079 & $(26)$ & & $0.0-1.3$ & .3 & ( 2.3$)$ & & $0.0-1.3$ & .3 & (1.4) & & $0.0-40.0$ & 10.5 & ( 4.1$)$ & \\
\hline OUGR & 3 & $0.000-.168$ & .066 & (2.2) & & $0.0-1.4$ & .6 & ( 4.0$)$ & & $0.0-2$ & .1 & ( . .2) & & $0.0-4.0$ & 2.0 & ( . .8) & \\
\hline SPAI & 2 & $0.000-.177$ & .062 & (2.1) & & $0.0-.7$ & .2 & $(1.5)$ & & $0.0-1.2$ & .5 & $(2.1)$ & & $0.0-8.0$ & 4.0 & $(1.6)$ & \\
\hline HYRI & 2 & $0.000-.097$ & .045 & ( 1.5$)$ & & $0.0-.5$ & .2 & ( 1.2$)$ & & $0.0-\quad .2$ & .1 & $(.4)$ & & $0.0-8.0$ & 4.0 & ( 1.6$)$ & \\
\hline ARBI & 2 & $0.000-.101$ & .035 & $(1.2)$ & & $0.0-.9$ & 3 & $(2.0)$ & & $0.0-.1$ & .0 & ( . .1) & & $0.0-8.0$ & 3.0 & $(1.2)$ & \\
\hline OUGA & 1 & & .034 & (1.1) & & & 4 & ( 2.6) & & & .0 & $(0.0)$ & & & 1.0 & $(.4)$ & \\
\hline OPPO & 4 & $.003-.078$ & .032 & $(1.1)$ & & $.0-.2$ & .1 & $(.7)$ & & $0.0-.2$ & .1 & $(.3)$ & & $0.0-13.0$ & 5.3 & $(2.0)$ & \\
\hline LUER & 1 & & .028 & ( .9) & & & .0 & ( . .1) & & & .1 & ( .6) & & & 5.5 & (2.1) & \\
\hline ASTR & 1 & & .027 & ( .9) & & & .1 & $(.7)$ & & & .3 & $(1.4)$ & & & 7.5 & ( 2.9) & \\
\hline PIED & 4 & $.017-.041$ & .026 & ( .9) & & $.2-.8$ & .4 & ( 2.8$)$ & & $0.0-0.0$ & 0.0 & $(0.0)$ & & $0.0-0.0$ & 0.0 & $(0.0)$ & \\
\hline SIHY & 4 & $.010-.051$ & .025 & $(8)$ & & $0.0-.1$ & .0 & $(.2)$ & & $.0-.6$ & .2 & $(8)$ & & $2.0-17.0$ & 6.3 & ( 2.4) & \\
\hline CEMO & 1 & & .024 & ( . .8) & & & .2 & ( 1.8$)$ & & & 0.0 & $(0.0)$ & & & 0.0 & $(0.0)$ & \\
\hline ARTR & 3 & $0.000-.039$ & .023 & $(.7)$ & & $0.0-.4$ & .1 & $(1.0)$ & & $0.0-.1$ & .0 & ( .1) & & $0.0-4.0$ & 2.0 & ( .8) & \\
\hline LEER & 2 & $0.000-.064$ & .020 & ( . .7) & & $0.0-.1$ & .0 & ( . .3) & & $0.0-\quad .8$ & .2 & ( .9) & & $0.0-20.0$ & 5.5 & (2.1) & \\
\hline ERIO1 & 1 & & .019 & ( . .6) & & & .0 & ( .1) & & & .0 & $(.2)$ & & & 3.0 & $(1.2)$ & \\
\hline SPCR & 4 & $.003-.024$ & .018 & ( .6) & & $.0-.1$ & 1 & (. .4) & & $0.0-.1$ & .1 & ( . 3) & & $0.0-7.0$ & 3.3 & ( 1.3$)$ & \\
\hline CHVI2 & 1 & & .015 & ( .5) & & & .1 & $(6)$ & & & .0 & $(0.0)$ & & & 1.0 & $(.4)$ & \\
\hline RHTR & 1 & & .014 & ( . .5) & & & .1 & $(.8)$ & & & .0 & $(0.0)$ & & & .5 & ( . .2) & \\
\hline CRYP & 1 & & .013 & ( 4) & & & .2 & $(1.2)$ & & & 0.0 & $(0.0)$ & & & 0.0 & $(0.0)$ & \\
\hline MELE & 1 & & .013 & ( .4) & & & .1 & $(.4)$ & & & .0 & $(.1)$ & & & 1.0 & $(.4)$ & \\
\hline AGAL & 1 & & .012 & ( . .4) & & & .0 & ( . 1) & & & .2 & $(.7)$ & & & 1.0 & $(.4)$ & \\
\hline DAFO & 1 & & .009 & ( . 3) & & & 1 & ( .4) & & & .0 & $(0.0)$ & & & .5 & $(.2)$ & \\
\hline OPER & 1 & & .008 & ( . .3) & & & .1 & $(.5)$ & & & .0 & $(0.0)$ & & & .5 & $(\quad .2)$ & \\
\hline YUCC & 1 & & .006 & ( .2) & & & .0 & $(0.0)$ & & & .0 & $(0.0)$ & & & 1.0 & $(.4)$ & \\
\hline CARE & 1 & & .005 & ( . .2) & & & 0.0 & $(0.0)$ & & & .0 & $(.2)$ & & & .5 & ( . .2) & \\
\hline ANSC & 2 & $0.000-.013$ & .005 & $(.2)$ & & $0.0-.2$ & .1 & (. .4) & & $0.0-0.0$ & 0.0 & $(0.0)$ & & $0.0-0.0$ & 0.0 & $(0.0)$ & \\
\hline SEMO & 1 & & .004 & ( 1) & & & 0 & $(.3)$ & & & 0.0 & $(0.0)$ & & & 0.0 & $(0.0)$ & \\
\hline ATCA & 1 & & .004 & ( . .1) & & & .1 & $(6)$ & & & 0.0 & $(0.0)$ & & & 0.0 & $(0.0)$ & \\
\hline AGSM & 1 & & .004 & ( . 1) & & & 0.0 & $(0.0)$ & & & .0 & $(.1)$ & & & .5 & $(.2)$ & \\
\hline ASME & 1 & & .004 & ( .1) & & & 0.0 & $(0.0)$ & & & .0 & $(0.0)$ & & & .5 & $(.2)$ & \\
\hline ARTE & 1 & & .004 & $(.1)$ & & & 0.0 & $(0.0)$ & & & .0 & $(0.0)$ & & & .5 & $(.2)$ & \\
\hline ORHY & 1 & & .003 & $(.1)$ & & & 0.0 & $(0.0)$ & & & .0 & $(0.0)$ & & & .5 & $(.2)$ & \\
\hline MURI1 & 1 & & .003 & ( .1) & & & 0.0 & $(0.0)$ & & & .0 & $(0.0)$ & & & .5 & $(.2)$ & \\
\hline EULA & 1 & & .003 & ( .1) & & & 0.0 & $(0.0)$ & & & .1 & $(.3)$ & & & .8 & ( . .3) & \\
\hline OPIM & 1 & & .002 & ( .1) & & & 0.0 & $(0.0)$ & & & .0 & $(0.0)$ & & & .8 & $(.3)$ & \\
\hline MUPU & 1 & & .002 & $(0.0)$ & & & 0 & ( . .1) & & & 0.0 & $(0.0)$ & & & 0.0 & $(0.0)$ & \\
\hline STEP & 1 & & .001 & $(0.0)$ & & & .0 & ( .1) & & & 0.0 & $(0.0)$ & & & 0.0 & $(0.0)$ & \\
\hline EPTO & 1 & & .001 & $(0.0)$ & & & .0 & ( .1) & & & 0.0 & $(0.0)$ & & & 0.0 & $(0.0)$ & \\
\hline SPCO & 1 & & .001 & $(0.0)$ & & & 0 & ( 1$)$ & & & 0.0 & $(0.0)$ & & & 0.0 & $(0.0)$ & \\
\hline OPCL & $?$ & & .001 & $(0.0)$ & & & 0 & ( . 1) & & & 0.0 & $(0.0)$ & & & 0.0 & $(0.0)$ & \\
\hline LERE & 1 & & .001 & $(0.0)$ & & & .0 & ( . 1) & & & 0.0 & $(0.0)$ & & & 0.0 & $(0.0)$ & \\
\hline & & & $\overline{3.000}$ & & & & 13.9 & & & & 22.7 & & & & & & \\
\hline
\end{tabular}

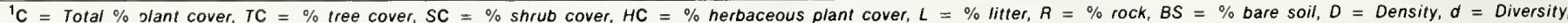
$S R=$ Species $r$, ness

$B S=100-(H C+L+R)$.

3 Plant species symbol (see Appendix B for full nomenclature).

${ }^{4} K=$ Constancy.

${ }_{T P}^{5}=$ Total percent for species with $I V \geqslant 0.1$. 
Table 12. - Vegetation and soil surface characteristics for plant community 7 (p.c.7).

COMMUNITY 7 : Jumo/Bogr

SITES

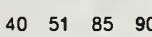

$\begin{array}{lllllllllllll}\text { No. Sltes } & \text { No. Trans. } & \frac{C}{16} & \frac{T C}{13.3} & \frac{S C}{5.7} & \frac{H C}{0.9} & \frac{L}{6.7} & \frac{R}{7.9} & \frac{R}{11.4} & \frac{B^{2}}{74.0} & \frac{D}{31.3} & \frac{d}{1.31} & \frac{S R}{44}\end{array}$ PERCENT COVER

DENSITY

PERCENT FREQUENCY

\begin{tabular}{|c|c|c|c|c|c|c|c|c|c|c|c|c|c|c|c|c|c|}
\hline SPECIES $^{3}$ & $K^{4}$ & RANGE & MEAN & $\%$ TOTAL & $T P^{5}$ & RANGE & MEAN & $\%$ TOTAL & $T P^{5}$ & RANGE & MEAN & $\%$ TOTAL & $T P^{5}$ & RANGE & MEAN & $\%$ TOTAL & $T P^{5}$ \\
\hline BOGR & 4 & $.512-1.560$ & 1.059 & (35.3) & & $.6-6.1$ & 3.5 & $(26.0)$ & & $3.8-48.7$ & 20.3 & $(65.0)$ & & $18.0-85.0$ & 55.3 & $(24.7)$ & \\
\hline HIJA & 4 & $.090-.922$ & .504 & (16.8) & & $.2-5.4$ & 1.7 & (12.9) & & $.3-12.9$ & 5.7 & $(18.2)$ & & $10.0-73.0$ & 46.3 & $(20.7)$ & \\
\hline JUMO & 4 & $.249-.638$ & .405 & (13.5) & & $1.7-9.6$ & 5.4 & $(40.3)$ & & $0.0-.0$ & .0 & $(0.0)$ & & $0.0-3.0$ & .8 & $(.3)$ & \\
\hline GUSA & 4 & $.134-.422$ & .237 & ( 7.9$)$ & & $.4-.9$ & .6 & $(4.8)$ & & $.3-\quad .8$ & .6 & $(2.0)$ & & $15.0-50.0$ & 33.3 & (14.9) & \\
\hline SPCR & 4 & $.014-.393$ & .137 & $(4.6)$ & 78.1 & $0.0-.3$ & .1 & $(.6)$ & 84.8 & $.1-2.2$ & .9 & ( 2.9) & 88.1 & $2.0-28.0$ & 15.0 & $(6.7)$ & 67.3 \\
\hline MUTO & 3 & $0.000-.159$ & .057 & ( 1.9$)$ & & $0.0-.3$ & .1 & ( .9) & & $0.0-3.3$ & .9 & ( 2.9$)$ & & $0.0-23.0$ & 7.5 & (3.4) & \\
\hline ARFI & 1 & & .047 & $(1.6)$ & & & .5 & $(4.0)$ & & & .0 & $(.1)$ & & & 2.0 & 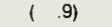 & \\
\hline BOER & 2 & $0.000-.157$ & .042 & $(1.4)$ & & $0.0-.2$ & .1 & $(.5)$ & & $0.0-4.1$ & 1.1 & ( 3.4$)$ & & $0.0-10.0$ & 3.3 & ( 1.5$)$ & \\
\hline BOER1 & 1 & & .042 & (1.4) & & & .0 & $(.2)$ & & & .3 & $(.9)$ & & & 2.0 & $(.9)$ & \\
\hline PEPU & 1 & & .040 & $(1.3)$ & & & .1 & $(.9)$ & & & .1 & $(.2)$ & & & 4.5 & $(2.0)$ & \\
\hline SIHY & 3 & $0.000-.096$ & .039 & ( 1.3$)$ & & $0.0-.1$ & .0 & $(.2)$ & & $0.0-.6$ & .2 & $(.7)$ & & $0.0-10.0$ & 5.8 & ( 2.6) & \\
\hline OPPO & 2 & $0.000-.121$ & .038 & ( 1.3$)$ & & $0.0-.1$ & .0 & $(.3)$ & & $0.0-.7$ & .2 & $(.7)$ & & $0.0-23.0$ & 7.8 & ( 3.5$)$ & \\
\hline ORHY & 2 & $0.000-.089$ & .031 & $(1.0)$ & & $0.0-.1$ & .0 & $(.2)$ & & $0.0-.2$ & .1 & $(.2)$ & & $0.0-13.0$ & 5.0 & ( 2.2$)$ & \\
\hline AROI2 & 1 & & .024 & $(.8)$ & & & .0 & $(.2)$ & & & .1 & $(.4)$ & & & 2.0 & $(.9)$ & \\
\hline PIED & 3 & $0.000-.060$ & .023 & $\left(\begin{array}{l}(.8) \\
)\end{array}\right.$ & & $0.0-.9$ & .3 & (2.2) & & $0.0-0.0$ & 0.0 & $(0.0)$ & & $0.0-0.0$ & 0.0 & $(0.0)$ & \\
\hline ARTR & 1 & & .022 & $(.7)$ & & & .1 & $(.5)$ & & & .0 & $(0.0)$ & & & 1.5 & $(.7)$ & \\
\hline OPUN & 1 & & .022 & $(.7)$ & & & .0 & $(.2)$ & & & .1 & $(.2)$ & & & 2.0 & $(.9)$ & \\
\hline SPHA & 2 & $0.000-.077$ & .020 & $(.7)$ & & $0.0-.2$ & .0 & $(.3)$ & & $0.0-.3$ & .1 & $\left(\begin{array}{l}.2 \\
)\end{array}\right.$ & & $0.0-8.0$ & 2.0 & $(.9)$ & \\
\hline MUPU & 1 & & .019 & ( .6) & & & .0 & $(.2)$ & & & .1 & ( . .3) & & & 1.3 & $(.6)$ & \\
\hline DAFO & 1 & & .019 & $(.6)$ & & & .0 & $(.1)$ & & & .1 & $\left(\begin{array}{l}(2) \\
(1)\end{array}\right.$ & & & 2.5 & $(1.1)$ & \\
\hline ARIS & 1 & & .019 & $\left(\begin{array}{l}(.6) \\
(\mathrm{n})\end{array}\right.$ & & & .0 & $(.1)$ & & & .1 & $(.2)$ & & & 2.0 & $(.9)$ & \\
\hline ARLO1 & 2 & $0.000-.038$ & .017 & ( . .6) & & $0.0-.0$ & .0 & $(0.0)$ & & $0.0-.1$ & .0 & (. .1) & & $0.0-8.0$ & 3.3 & (1.5) & \\
\hline SELO & 1 & & .016 & 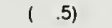 & & & .0 & $(.1)$ & & & .1 & $\left(\begin{array}{l}(.2) \\
)\end{array}\right.$ & & & 3.3 & ( 1.5$)$ & \\
\hline ERIO1 & 2 & $0.000-.052$ & .016 & $(.5)$ & & $0.0-0.0$ & 0.0 & $(0.0)$ & & $0.0-.1$ & .0 & $($ (.1) & & $0.0-8.0$ & 2.5 & ( 1.1$)$ & \\
\hline SPCO & 1 & & .015 & $(.5)$ & & & .0 & ( .1) & & & .0 & ( . .1) & & & 2.0 & ( .9) & \\
\hline ATCA & 1 & & .012 & $(.4)$ & & & .2 & $(1.4)$ & & & 0.0 & $(0.0)$ & & & 0.0 & $(0.0)$ & \\
\hline HASP2 & 1 & & .011 & $(.4)$ & & & .0 & (.1) & & & .1 & $(.2)$ & & & 2.5 & ( 1.1$)$ & \\
\hline BOCU & 1 & & .009 & ( . .3) & & & 0.0 & $(0.0)$ & & & .1 & ( . .3) & & & 1.8 & $(.8)$ & \\
\hline RHTR & 1 & & .008 & ( . .3) & & & .1 & (1.1) & & & 0.0 & $(0.0)$ & & & 0.0 & $(0.0)$ & \\
\hline YUGL & 1 & & .005 & $(.2)$ & & & .0 & $(.1)$ & & & .0 & $(0.0)$ & & & 8 & $(.3)$ & \\
\hline EPTO & 1 & & .005 & $\left(\begin{array}{ll}(2) \\
\text { ( }\end{array}\right.$ & & & .0 & $(.1)$ & & & .0 & $(0.0)$ & & & 8 & $(.3)$ & \\
\hline QUGA & 1 & & .004 & ( .1) & & & .0 & ( . .2) & & & 0.0 & $(0.0)$ & & & 0.0 & $(0.0)$ & \\
\hline CERC1 & 1 & & .004 & $(.1)$ & & & .0 & $(.2)$ & & & 0.0 & $(0.0)$ & & & 0.0 & $(0.0)$ & \\
\hline OROB & 1 & & .004 & ( . .1) & & & 0.0 & $(0.0)$ & & & .0 & $(0.0)$ & & & .8 & $\left(\begin{array}{l}(.3) \\
(.5)\end{array}\right.$ & \\
\hline MIMU & 1 & & .004 & $\left(\begin{array}{l}1 \\
(\quad .1)\end{array}\right.$ & & & .1 & 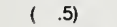 & & & 0.0 & $(0.0)$ & & & 0.0 & $(0.0)$ & \\
\hline ASCL & 1 & & .004 & ( $(.1)$ & & & 0.0 & $(0.0)$ & & & .0 & $(0.0)$ & & & .8 & ( ( . .3) & \\
\hline ALLI & 1 & & .004 & ( . 1) & & & 0.0 & $(0.0)$ & & & .0 & $(0.0)$ & & & .8 & 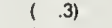 & \\
\hline SENE & 1 & & .003 & ( .1) & & & .1 & $(.4)$ & & & 0.0 & $(0.0)$ & & & 0.0 & $(0.0)$ & \\
\hline PHYS & 1 & & .003 & $(.1)$ & & & .0 & $(.3)$ & & & 0.0 & $(0.0)$ & & & 0.0 & $(0.0)$ & \\
\hline MIRA & 1 & & .003 & $(.1)$ & & & 0.0 & $(0.0)$ & & & .0 & $(0.0)$ & & & .8 & $(.3)$ & \\
\hline LYPA1 & 1 & & .003 & ( . .1) & & & 0.0 & $(0.0)$ & & & .0 & $(0.0)$ & & & .8 & $(.3)$ & \\
\hline LESO & 1 & & .003 & $\left(\begin{array}{l}(.1) \\
(\end{array}\right.$ & & & 0.0 & $(0.0)$ & & & .0 & $(0.0)$ & & & .8 & ( . .3) & \\
\hline CovI & 1 & & .003 & ( . .1) & & & 0.0 & $(0.0)$ & & & .0 & $(0.0)$ & & & .8 & (. .3) & \\
\hline OPIM & 1 & & .002 & $(.1)$ & & & .0 & $(2)$ & & & 0.0 & $(0.0)$ & & & 0.0 & $(0.0)$ & \\
\hline & & & 3.000 & & & & 13.3 & & & & 31.3 & & & & & & \\
\hline
\end{tabular}

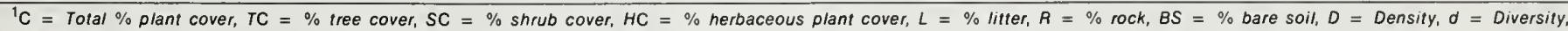
$S R=$ Species richness.

${ }^{2} B S=100-(H C+i+R)$.

3 Plant species symbol (see Appendix B for full nomenclature).

${ }^{4} \mathrm{~K}=$ Constancy.

${ }^{5} T P=$ Total percent for species with $I V \geqslant 0.1$. 
Table 13. - Vegetation and soil surface characteristics for plant community 8 (p.c.8).

COMMUNITY 8 : Jumo/Artr/Hija-Spcr SITES $\quad 30$
Mean ${ }^{1}$
IMPORTANCE VALUE

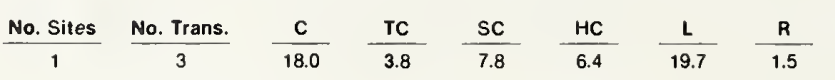
DENSITY
$\frac{\mathrm{BS}^{2}}{72.4} \quad \frac{\mathrm{D}}{25.2} \quad \frac{\mathrm{d}}{1.33} \quad \frac{\mathrm{SR}}{15}$

PERCENT FREQUENCY

\begin{tabular}{|c|c|c|c|c|c|c|c|c|c|c|c|c|c|c|c|c|c|}
\hline SPECIES $^{3}$ & $k^{4}$ & RANGE & MEAN & $\%$ TOTAL & $T P^{5}$ & RANGE & MEAN & $\%$ TOTAL & $T P^{5}$ & RANGE & MEAN & $\%$ TOTAL & $T P^{5}$ & RANGE & MEAN & $\%$ TOTAL & $T P^{5}$ \\
\hline HIJA & 1 & & .869 & $(29.0)$ & & & 3.9 & $(21.7)$ & & & 10.3 & $(40.8)$ & & & 67.0 & $(24.5)$ & \\
\hline SPCR & 1 & & .741 & (24.7) & & & .8 & ( 4.6$)$ & & & 11.0 & $(43.8)$ & & & 70.0 & (25.5) & \\
\hline ARTR & 1 & & .390 & $(13.0)$ & & & 5.7 & (31.9) & & & .3 & (1.1) & & & 17.0 & $(6.2)$ & \\
\hline GUSA & 1 & & .242 & ( 8.1$)$ & & & 1.8 & $(10.0)$ & & & .8 & (3.2) & & & 30.0 & (10.9) & \\
\hline JUMO & 1 & & .209 & $(7.0)$ & & & 3.8 & $(21.0)$ & & & 0.0 & $(0.0)$ & & & 0.0 & $(0.0)$ & \\
\hline LEER & 1 & & .172 & $(5.7)$ & & & .1 & $(.4)$ & & & 1.2 & ( 4.6) & & & 34.0 & (12.4) & \\
\hline SIHY & 1 & & .113 & ( 3.8$)$ & 91.3 & & .2 & ( 1.3$)$ & 91.1 & & .7 & ( 2.7) & 96.2 & & 20.0 & ( 7.3$)$ & 86.8 \\
\hline AGSM & 1 & & .061 & $(2.0)$ & & & .0 & $(.2)$ & & & .3 & (1.1) & & & 13.0 & (4.7) & \\
\hline OPPO & 1 & & .055 & ( 1.8$)$ & & & .3 & $(1.8)$ & & & .3 & ( 1.2$)$ & & & 7.0 & ( 2.6) & \\
\hline ARLO1 & 1 & & .052 & $(1.7)$ & & & .3 & $(1.8)$ & & & .2 & ( $\quad .9)$ & & & 7.0 & ( 2.6) & \\
\hline SPAI & 1 & & .051 & $(1.7)$ & & & .6 & ( 3.5$)$ & & & .1 & $(.4)$ & & & 3.0 & ( 1.1$)$ & \\
\hline SPPA1 & 1 & & .014 & ( . .5) & & & 0.0 & $(0.0)$ & & & .0 & ( .1) & & & 3.0 & ( 1.1$)$ & \\
\hline SPCO2 & 1 & & .014 & ( . .5) & & & 0.0 & $(0.0)$ & & & .0 & ( . .1) & & & 3.0 & (1.1) & \\
\hline CRYP & 1 & & .011 & $\left(\begin{array}{l}(.4) \\
(\end{array}\right)$ & & & .2 & $(1.1)$ & & & 0.0 & $(0.0)$ & & & 0.0 & $(0.0)$ & \\
\hline ORHY & 1 & & .007 & ( .2) & & & .1 & $(.7)$ & & & 0.0 & $(0.0)$ & & & 0.0 & $(0.0)$ & \\
\hline & & & 3.001 & & & & 18.0 & & & & 25.2 & & & & & & \\
\hline
\end{tabular}

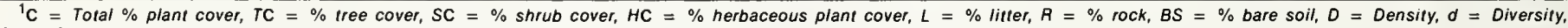
$S R_{2}=$ Species richness.

$B S=100-(H C+i+R)$

${ }^{3}$ Plam species symbol (see Appendix B for full nomenclature)

${ }^{4} K=$ Constancy.

${ }^{5} T P=$ Total percent for species with $I V \geqslant 0.1$

Table 14. - Vegetation and soil surface characteristics for plant community 9 (p.c.9).

COMMUNITY 9 : Artr/Bogr-HIja

$\begin{array}{llllllll}\text { SITES } & 5 & 7 & 9 & 22 & 23 & 37 & 146\end{array}$

Mean ${ }^{1}$

\begin{tabular}{|c|c|c|c|c|c|c|c|c|c|c|c|c|c|c|c|c|c|c|}
\hline & \multicolumn{5}{|c|}{ IMPORTANCE VALUE } & \multicolumn{4}{|c|}{ PERCENT COVER } & \multicolumn{5}{|c|}{ DENSITY } & \multicolumn{4}{|c|}{ PERCENT FREQUENCY } \\
\hline SPECIES $^{3}$ & $k^{4}$ & RANGE & MEAN & $\%$ TOTAL & $T P^{5}$ & RANGE & MEAN & $\%$ TOTAL & $T P^{5}$ & RAN & GE & MEAN & $\%$ TOTAL & $T P^{5}$ & RANGE & MEAN & $\%$ TOTAL & $T P^{5}$ \\
\hline BOGR & 7 & $.770-2.202$ & 1.412 & $(47.1)$ & & $3.7-16.8$ & 8.8 & $(43.0)$ & & $15.7=$ & 118.8 & 43.0 & $(76.8)$ & & $70.0-100.0$ & 85.1 & $(27.1)$ & \\
\hline ARTR & 7 & $.106-1.103$ & .697 & (23.2) & & $.8-12.8$ & 8.9 & (43.5) & & $3-$ & 4.9 & 1.9 & (3.4) & & $15.0-97.0$ & 66.4 & (21.2) & \\
\hline HIJA & 6 & $0.000-.821$ & .370 & (12.3) & & $0.0-3.1$ & 1.3 & (6.4) & & $0.0-$ & 17.0 & 6.8 & (12.1) & & $0.0-95.0$ & 50.9 & $(16.2)$ & \\
\hline SPCA & 7 & $.017-.207$ & .124 & ( 4.1$)$ & 86.7 & $.0-1.3$ & .4 & (2.1) & 95.0 & $.0-$ & 2.2 & 1.1 & $(1.9)$ & 94.2 & $3.0-40.0$ & 24.1 & $(7.7)$ & 72.2 \\
\hline GUSA & 6 & $0.000-.244$ & .088 & ( 2.9) & & $0.0-1.2$ & .3 & $(1.4)$ & & $0.0-$ & 1.6 & .5 & $(1.0)$ & & $0.0-50.0$ & 20.3 & $(6.5)$ & \\
\hline SIHY & 7 & $.039-.144$ & .087 & (2.9) & & $0.0-.5$ & .2 & (. .9) & & $.1-$ & 1.0 & .6 & $(1.0)$ & & $10.0-30.0$ & 19.3 & (6.1) & \\
\hline HASP2 & 3 & $0.000-.272$ & .053 & ( 1.8$)$ & & $0.0-.3$ & .1 & (. .4) & & $0.0-$ & 4.1 & .7 & $(1.2)$ & & $0.0-53.0$ & 11.3 & ( 3.6$)$ & \\
\hline AGSM & 3 & $0.000-.168$ & .030 & $(1.0)$ & & $0.0-.3$ & .1 & ( . .3) & & $0.0-$ & 2.2 & .4 & $(.7)$ & & $0.0-37.0$ & 6.3 & $(2.0)$ & \\
\hline OPPO & 3 & $0.000-.111$ & .021 & ( .7) & & $0.0-3$ & .0 & ( . 2) & & $0.0-$ & .7 & .1 & $(.2)$ & & $0.0-27.0$ & 5.3 & $(1.7)$ & \\
\hline SPHA & 4 & $0.000-.058$ & .018 & ( . .6) & & $0.0-0.0$ & 0.0 & $(0.0)$ & & $0.0-$ & .8 & .1 & ( . .2) & & $0.0-10.0$ & 4.3 & (1.4) & \\
\hline MUTO & 2 & $0.000-.073$ & .018 & ( .6) & & $0.0-\quad .1$ & .0 & (.1) & & $0.0-$ & .9 & .2 & ( .3) & & $0.0-20.0$ & 4.3 & $(1.4)$ & \\
\hline SPAI & 2 & $0.000-.081$ & .018 & $(.6)$ & & $0.0-\quad 4$ & .1 & ( .5) & & $0.0-$ & 1.9 & .3 & ( . .5) & & $0.0-\quad 7.0$ & 2.0 & $(.6)$ & \\
\hline AGCR & 1 & & .012 & (.4) & & & .0 & ( . .2) & & & & .1 & ( .2) & & & 2.9 & ( . .9) & \\
\hline ARLO1 & 2 & $0.000-.051$ & .011 & (. .4) & & $0.0-.4$ & .1 & ( . .4) & & $0.0-$ & 1.0 & .2 & (. .3) & & $0.0-3.0$ & .9 & ( . .3) & \\
\hline SPDI & 1 & & .009 & ( .3) & & & 0.0 & $(0.0)$ & & & & .0 & (.1) & & & 2.9 & ( .9) & \\
\hline STCO1 & 1 & & .008 & ( . .3) & & & .1 & ( . .4) & & & & .0 & $(0.0)$ & & & 1.4 & ( . .5) & \\
\hline COVI & 2 & $0.000-.035$ & .007 & $(.2)$ & & $0.0-0.0$ & 0.0 & $(0.0)$ & & $0.0-$ & .3 & .1 & $(.1)$ & & $0.0-10.0$ & 1.9 & $(.6)$ & \\
\hline CELA & 2 & $0.000-.034$ & .006 & $(.2)$ & & $0.0-.3$ & .0 & ( . .2) & & $0.0-$ & .1 & .0 & $(0.0)$ & & $0.0-\quad 5.0$ & 1.1 & (. .4) & \\
\hline ARFE1 & 1 & & .005 & ( .2) & & & 0.0 & $(0.0)$ & & & & .0 & $(0.0)$ & & & 1.4 & ( . .5) & \\
\hline ERIO1 & 1 & & .002 & ( .1) & & & 0.0 & $(0.0)$ & & & & .0 & $(0.0)$ & & & .4 & ( .1) & \\
\hline UNKF & 1 & & .002 & (.1) & & & .0 & $(0.0)$ & & & & .0 & $(0.0)$ & & & .4 & ( .1) & \\
\hline WCOMP & 1 & & .002 & (. .1) & & & 0.0 & $(0.0)$ & & & & .0 & $(0.0)$ & & & .4 & ( .1) & \\
\hline NDLLF & 1 & & .002 & (.1) & & & 0.0 & $(0.0)$ & & & & .0 & $(0.0)$ & & & .4 & ( .1) & \\
\hline & & & $\overline{3.000}$ & & & & 20.5 & & & & & 56.1 & & & & & & \\
\hline
\end{tabular}

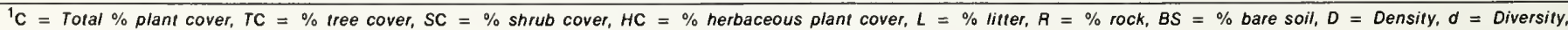
$S R=$ Species richness.

${ }^{2} B S=100-(H C+L+R)$.

${ }^{3}$ Plant species symbol (see Appendix $B$ for full nomenclature)

${ }^{4} K=$ Constancy.

${ }^{5} T P=$ Total percent for species with $I V>0.1$. 
Table 15.-Vegetation and soil surface characteristics for plant community 10 (p.c.10).

Mean $^{1}$

COMMUNITY 10 : Artr.Gusa/Bogr.HIja

SITES $\quad 1 \quad 4$

$\begin{array}{lllllllllllll}\text { No. Sites } & \text { No. Trans. } & \frac{C}{9} & \frac{\mathrm{TC}}{19.4} & \frac{\mathrm{SC}}{0.1} & \frac{\mathrm{HC}}{7.7} & \frac{\mathrm{L}}{11.6} & \frac{\mathrm{R}}{10.5} & \frac{\mathrm{BS}^{2}}{0.1} & \frac{\mathrm{D}}{77.8} & \frac{\mathrm{d}}{56.0} & \frac{\mathrm{S}}{1.38} & \frac{\mathrm{SR}}{30}\end{array}$

IMPORTANCE VALUE

PERCENT COVER

DENSITY

PERCENT FREQUENCY

\begin{tabular}{|c|c|c|c|c|c|c|c|c|c|c|c|c|c|c|c|c|c|}
\hline SPECIES 3 & $k^{4}$ & RANGE & MEAN & $\%$ TOTAL & $T P^{5}$ & RANGE & MEAN & $\%$ TOTAL & $T P^{5}$ & RANGE & MEAN & $\%$ TOTAL & $T P^{5}$ & RANGE & MEAN & $\%$ TOTAL & $T P^{5}$ \\
\hline BOGR & 3 & $.789-1.587$ & 1.059 & $(35.3)$ & & $3.8-9.9$ & 5.9 & $(30.5)$ & & $22.9-47.6$ & 31.6 & $(56.4)$ & & $60.0-87.0$ & 75.7 & $(18.9)$ & \\
\hline HIJA & 3 & $.437-.813$ & .605 & (20.2) & & $2.8-3.4$ & 3.1 & (16.3) & & $8.7-19.5$ & 13.1 & (23.4) & & $50.0-97.0$ & 80.0 & $(20.0)$ & \\
\hline ARTR & 3 & $.342-.537$ & .465 & (15.5) & & $1.8-10.5$ & 5.6 & (28.7) & & $.5-1.6$ & .9 & $(1.7)$ & & $23.0-63.0$ & 42.0 & (10.5) & \\
\hline GUSA & 3 & $.118-.314$ & .214 & (7.1) & & $.8-2.3$ & 1.7 & ( 8.8$)$ & & $.6-2.4$ & 1.3 & ( 2.4$)$ & & $17.0-77.0$ & 48.0 & (12.0) & \\
\hline SIHY & 3 & $.071-.235$ & .129 & ( 4.3) & & $.2-\quad .5$ & .4 & (2.2) & & $.3-4.1$ & 1.6 & (2.9) & & $13.0-63.0$ & 33.0 & ( 8.2$)$ & \\
\hline AGSM & 3 & $.017-.188$ & .126 & $(4.2)$ & 86.6 & $.0-\quad .5$ & .2 & $(1.3)$ & 87.8 & $.1-4.5$ & 2.7 & $(4.8)$ & 91.6 & $3.0-50.0$ & 27.7 & ( 6.9) & 76.5 \\
\hline STNE & 1 & & .087 & ( 2.9$)$ & & & .5 & ( 2.8$)$ & & & .8 & $(1.4)$ & & & 23.3 & ( 5.8$)$ & \\
\hline AGCA & 1 & & .064 & (2.1) & & & .6 & ( 3.3 ) & & & .6 & (1.1) & & & 12.3 & ( 3.1$)$ & \\
\hline LEER & 1 & & .043 & $(1.4)$ & & & .2 & (1.1) & & & 1.1 & ( 2.0$)$ & & & 5.7 & $(1.4)$ & \\
\hline SPAI & 2 & $0.000-.076$ & .038 & ( 1.3$)$ & & $0.0-.4$ & .1 & $(.7)$ & & $0.0-1.6$ & 1.0 & ( 1.8$)$ & & $0.0-13.0$ & 5.3 & ( 1.3$)$ & \\
\hline ORHY & 2 & $0.000-.057$ & .033 & (1.1) & & $0.0-.4$ & .2 & ( 1.0$)$ & & $0.0-\quad .4$ & .2 & ( .4) & & $0.0-17.0$ & 10.0 & ( 2.5$)$ & \\
\hline EUPH & 1 & & .030 & $(1.0)$ & & & .1 & ( . .3) & & & .4 & ( . .7) & & & 10.0 & ( 2.5$)$ & \\
\hline SPCR & 3 & $.007-.032$ & .019 & ( .6) & & $0.0-.1$ & .0 & ( .1) & & $.0-.3$ & .2 & ( . .3) & & $3.0-7.0$ & 5.7 & ( 1.4$)$ & \\
\hline ATCA & 1 & & .016 & ( .5) & & & .2 & $(1.2)$ & & & .0 & $(0.0)$ & & & 2.3 & & \\
\hline CHNA & 1 & & .015 & ( .5) & & & .2 & (1.1) & & & .1 & ( . .2) & & & 1.0 & & \\
\hline PIED & 2 & $0.000-.015$ & .009 & 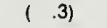 & & $0.0-.3$ & .1 & $($ ( .6) & & $0.0-\quad .1$ & .0 & $(0.0)$ & & $0.0-7.0$ & 2.3 & & \\
\hline ATCO & 1 & & .008 & ( . .3) & & & 0.0 & $(0.0)$ & & & .0 & ( . 1) & & & 3.3 & ( .8$)$ & \\
\hline ATOB & 1 & & .007 & ( . .2) & & & .0 & $(.2)$ & & & .0 & $(.1)$ & & & 1.0 & $\left(\begin{array}{l}(.2 \\
(\end{array}\right)$ & \\
\hline UKCOM & 1 & & .003 & (.1) & & & .0 & (. .1) & & & .0 & $(0.0)$ & & & 1.0 & (. .2) & \\
\hline TECA & 1 & & .003 & (. .1) & & & .0 & (.1) & & & .0 & $(0.0)$ & & & 1.0 & ( . .2) & \\
\hline CELA & 1 & & .003 & ( .1) & & & .0 & ( .1) & & & .0 & $(0.0)$ & & & 1.0 & ( . .2) & \\
\hline SPDI & 1 & & .003 & ( . .1) & & & 0.0 & $(0.0)$ & & & .0 & $(0.0)$ & & & 1.0 & ( . .2) & \\
\hline OROB & 1 & & .002 & ( .1) & & & 0.0 & $(0.0)$ & & & .0 & $(0.0)$ & & & 1.0 & ( . .2) & \\
\hline OPPO & 1 & & .002 & ( . .1) & & & 0.0 & $(0.0)$ & & & .0 & $(0.0)$ & & & 1.0 & ( . .2) & \\
\hline MIMU & 1 & & .002 & (.1) & & & 0.0 & $(0.0)$ & & & .0 & $(0.0)$ & & & 1.0 & (. .2) & \\
\hline JUMO & 1 & & .002 & ( . 1) & & & 0.0 & $(0.0)$ & & & .0 & $(0.0)$ & & & 1.0 & ( . .2) & \\
\hline HASP & 1 & & .002 & (.1) & & & 0.0 & $(0.0)$ & & & .0 & $(0.0)$ & & & 1.0 & ( . .2) & \\
\hline CHPA & 1 & & .002 & $(.1)$ & & & 0.0 & $(0.0)$ & & & .0 & $(0.0)$ & & & 1.0 & $\left(\begin{array}{l}\text { ( .2) } \\
\text { (n) }\end{array}\right.$ & \\
\hline ASFL 2 & 1 & & .002 & ( .1) & & & 0.0 & $(0.0)$ & & & .0 & $(0.0)$ & & & 1.0 & ( . .2) & \\
\hline \multirow[t]{2}{*}{ ASFL1 } & 1 & & .002 & (.1) & & & 0.0 & $(0.0)$ & & & .0 & $(0.0)$ & & & 1.0 & ( . .2) & \\
\hline & & & $\overline{2.999}$ & & & & 19.4 & & & & 56.0 & & & & & & \\
\hline
\end{tabular}

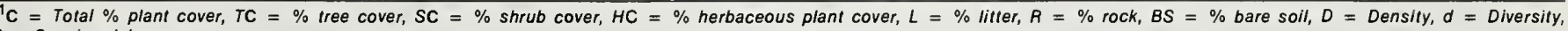
$S R=$ Species richness.

$2 B S=100-(H C+L+R)$.

3 Plant species symbol (see Appendix B for full nomenclature).

${ }_{5}^{4} K=$ Constancy.

${ }^{5} T P=$ Total percent for species with $I V \geqslant 0.1$. 
Table 16. - Vegetation and soil surface characteristics for plant community 11 (p.c.11).

COMMUNITY 11 : Artr/Bogr.HIja.Spai

$\begin{array}{lllll}\text { SITES } & 16 & 87 & 92 & 94\end{array}$

Mean ${ }^{1}$

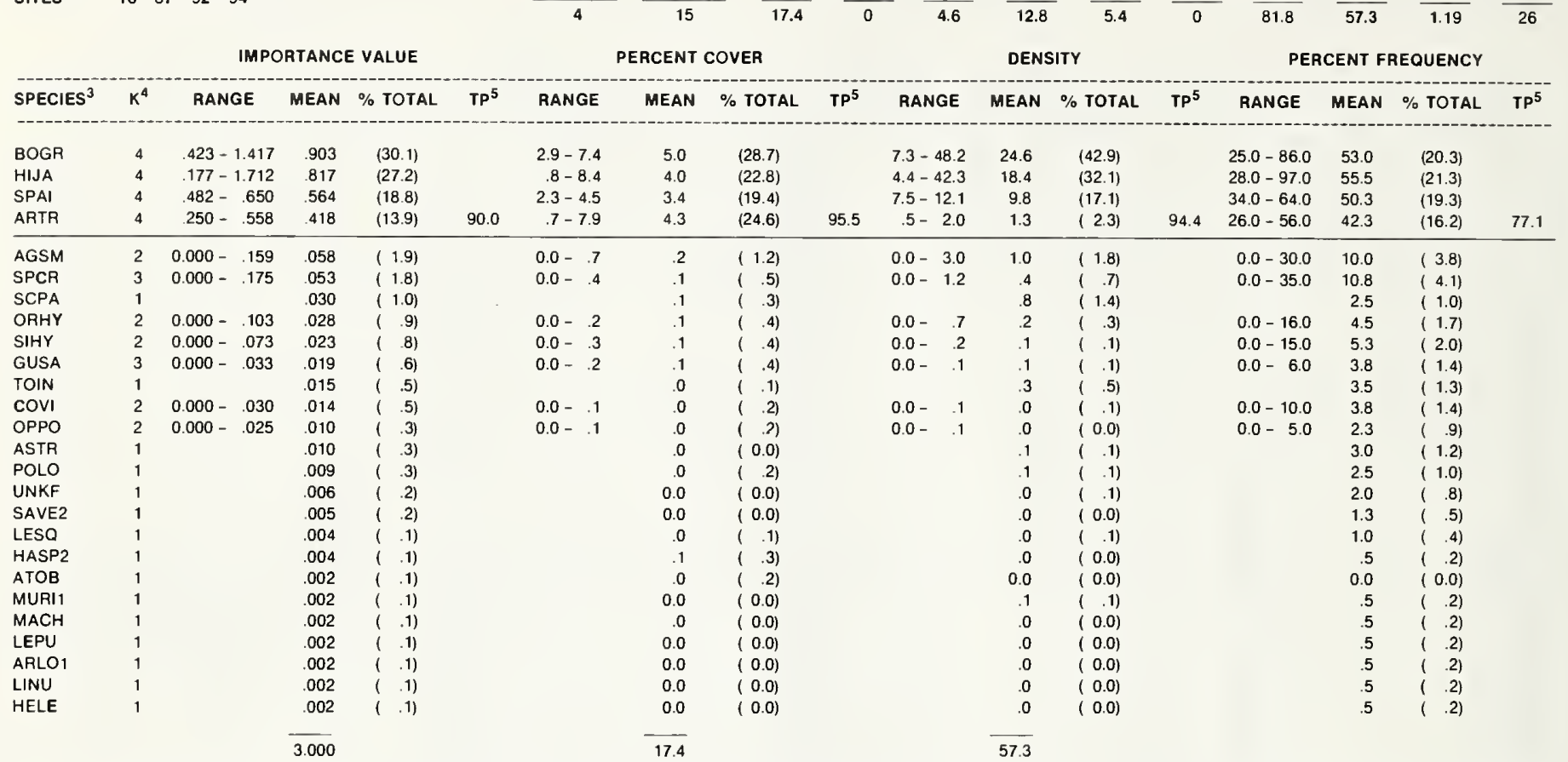

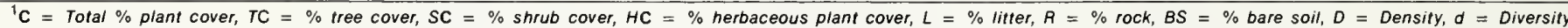
$S R=$ Species richness.
$2 B S=100-(H C+L$

${ }_{4}^{3}$ Plant species symbol (see Appendix B for full nomenclature).

${ }_{5} K=$ Constancy.

${ }^{5} T P=$ Total percent for species with $I V \geqslant 0.1$.

Table 17.-Vegetation and soil surface characteristics for plant community 12 (p.c.12)

COMMUNITY 12 : Artr.Gusa/HIja.Spal

SITES 23

Mean'

$\begin{array}{lllllllllllllll}\text { No. SItes } & \text { No. Trans. } & \frac{C}{7} & \frac{\text { C }}{15.2} & \frac{\text { SC }}{0} & \frac{H C}{6.8} & \frac{\text { L }}{8.4} & \frac{\text { L }}{5.9} & \frac{\text { R }}{0} & \frac{\text { BS }^{2}}{85.7} & \frac{\text { D }}{40.0} & \frac{\text { d }}{1.59} & \frac{\text { SR }}{17}\end{array}$

IMPORTANCE VALUE PERCENT COVER

DENSITY

PERCENT FREQUENCY

\begin{tabular}{|c|c|c|c|c|c|c|c|c|c|c|c|c|c|c|c|c|c|}
\hline SPECIES $^{3}$ & $k^{4}$ & RANGE & MEAN & $\%$ TOTAL & $T P^{5}$ & RANGE & MEAN & \% TOTAL & $T P^{5}$ & RANGE & MEAN & $\%$ TOTAL & $T P^{5}$ & RANGE & MEAN & $\%$ TOTAL & $T P^{5}$ \\
\hline HIJA & 2 & $.489-.964$ & .727 & $(24.2)$ & & $1.5-2.9$ & 2.2 & (14.5) & & $7.6-22.3$ & 14.9 & (37.3) & & $55.0-56.0$ & 55.5 & (21.5) & \\
\hline ARTR & 2 & $.518-.729$ & .624 & (20.8) & & $5.3-7.2$ & 6.2 & (41.1) & & $.7-1.2$ & 1.0 & (2.4) & & $45.0-50.0$ & 47.5 & (18.4) & \\
\hline SPAI & 2 & $.517-.646$ & .582 & $(19.4)$ & & $2.0-2.5$ & 2.2 & (14.8) & & $12.2-12.3$ & 12.2 & $(30.6)$ & & $22.0-45.0$ & 33.5 & $(13.0)$ & \\
\hline BOGR & 2 & $.296-.308$ & .302 & $(10.1)$ & & $1.8-2.2$ & 2.0 & (13.2) & & $3.3-4.1$ & 3.7 & (9.2) & & $20.0-20.0$ & 20.0 & $(7.7)$ & \\
\hline SIHY & 2 & $.089-.377$ & .233 & (7.8) & & $.1-1.7$ & .9 & ( 5.8$)$ & & $.8-5.0$ & 2.9 & ( 7.1$)$ & & $14.0-40.0$ & 27.0 & $(10.4)$ & \\
\hline GUSA & 2 & $.179-.218$ & .199 & (6.6) & & $.6-.7$ & .6 & ( 4.2) & & $1.1-1.2$ & 1.1 & ( 2.9$)$ & & $30.0-34.0$ & 32.0 & (12.4) & \\
\hline AGCR & 1 & & .167 & (5.6) & 94.5 & & .6 & ( 3.6$)$ & 97.2 & & 3.0 & $(7.4)$ & 96.9 & & 15.0 & ( 5.8$)$ & 89.2 \\
\hline AGSM & 2 & $.020-.073$ & .047 & ( 1.6$)$ & & $.1-.2$ & .1 & ( .9) & & $.1-\quad .5$ & .3 & $(.7)$ & & $2.0-15.0$ & 8.5 & ( 3.3 ) & \\
\hline ORHY & 2 & $.001-.071$ & .036 & ( 1.2$)$ & & $.0-.3$ & .1 & ( .9) & & $0.0-\quad .8$ & .4 & ( .9) & & $0.0-10.0$ & 5.0 & ( 1.9$)$ & \\
\hline SCPA & 2 & $.020-.035$ & .028 & 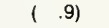 & & $0.0-.1$ & .1 & $\left(\begin{array}{l}\text { ( } .5) \\
\text { (n) }\end{array}\right.$ & & $.1-.3$ & .2 & $\left(\begin{array}{l}\text { ( } \\
\text { (5) }\end{array}\right.$ & & $4.0-5.0$ & 4.5 & ( 1.7$)$ & \\
\hline SPHA & 1 & & .017 & $\left(\begin{array}{l}(.6) \\
(5)\end{array}\right.$ & & & 0.0 & $(0.0)$ & & & .2 & $(.4)$ & & & 3.0 & ( 1.2$)$ & \\
\hline SPCR & 1 & & .015 & $(.5)$ & & & .1 & $(.5)$ & & & 0 & $\left(\begin{array}{l}1 \\
(\end{array}\right)$ & & & 2.0 & $(8)$ & \\
\hline STCO & 1 & & .007 & $\left(\begin{array}{l}(.2) \\
(\quad)\end{array}\right.$ & & & .0 & ( . .1) & & & .0 & $\left(\begin{array}{l}(1) \\
(\end{array}\right.$ & & & 1.0 & $\left(\begin{array}{l}(.4) \\
(\end{array}\right.$ & \\
\hline ATOB & 1 & & .006 & $(.2)$ & & & 0.0 & $(0.0)$ & & & .1 & $(.2)$ & & & 1.0 & & \\
\hline SAKA & 1 & & .005 & $(.2)$ & & & 0.0 & $(0.0)$ & & & .0 & (. .1) & & & 1.0 & $\left(\begin{array}{ll}( & .4\end{array}\right)$ & \\
\hline LEER & 1 & & .005 & $(.2)$ & & & 0.0 & $(0.0)$ & & & .0 & $($ ( .1) & & & 1.0 & $(.4)$ & \\
\hline ALLI & 1 & & .005 & $($ ( .2) & & & 0.0 & $(0.0)$ & & & .0 & $(0.0)$ & & & 1.0 & ( .4) & \\
\hline & & & 3.000 & & & & 15.2 & & & & 40.0 & & & & & & \\
\hline
\end{tabular}

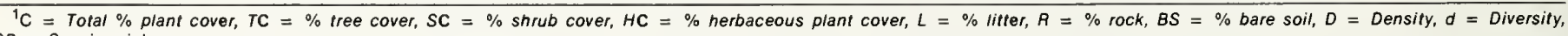
$S R=$ Species richness.
${ }_{2} B S=100-(H C+1$

${ }^{2} B S=100-(H C+L+R)$.

3 plant species symbol (see Appendix $B$ for full nomenclature).

${ }^{4} K=$ Constancy.

${ }^{5} T P=$ Total percent for species with $N \geqslant 0.1$. 
Table 18. - Vegetation and soil surface characteristics for plant community 13 (p.c.13).

Mean $^{1}$

COMMUNITY 13 : Artr.Gusa/Bogr-Agsm

$\begin{array}{lllllll}\text { SITES } & 140 & 141 & 142 & 143 & 144 & 145\end{array}$ $\begin{array}{lllllllllllllll}\text { No. Slles } & \text { No. Trans. } & \frac{C}{9} & \frac{T C}{24.8} & \frac{S C}{10.6} & \frac{H C}{14.2} & \frac{L}{16.0} & \frac{R}{0} & \frac{B^{2}}{69.8} & \frac{D}{34.3} & \frac{d}{1.66} & \frac{S R}{41}\end{array}$

DENSITY

PERCENT FREQUENCY

IMPORTANCE VALUE

PERCENT COVER

RANGE MEAN \% TOTAL TP

$\begin{array}{lllll}\text { SPECIES }^{3} & K^{4} & \text { RANGE } & \text { MEAN \% TOTAL TP } \\ \text { BOGR } & 6 & .014-1.219 & .680 & (22.7)\end{array}$

BOGR

AGSM

ARTR

AGDE

GUSA

HIJA

$4 \quad 0.000-.412 \quad 147$

SIHY $\quad 5 \quad 0.000-.390$

$\begin{array}{lllll}\text { ASTR } & 3 & 0.000-.233 & .081\end{array}$

$\begin{array}{llll}\text { SPCR } & 5 & 0.000-.183 & .059\end{array}$

$\begin{array}{llll}\text { STCO } 1 & 3 & 0.000-.192 & .045\end{array}$

SEMU $4 \quad 2 \quad 0.000-.116$

SPAI

LEER

CELA

SPDI

PSTA

ASCE

CHDE

ERLO1

MURI1

MUTO

CYMO

MUWR

ORHY

LALE

LALE
ERIO1

POFE

MEOF

THME

HYRI

PIED

POPA

GRAR

SEMU1

ORMU

COVI

ERMI

ARNO

HASP

(19.6)

(19.4)

( 6.3$)$

$(5.0)$

(4.5) 82.4

RANGE MEAN \% TOTAL TP 5

RANGE MEAN \% TOTAL TP 5

( 4.5)

.3- 21.8

8.2
1.5
9.7

( 2.7)

$82.4-0.0$

$.3-21.8$
$.8-2.1$
$4.5-17.7$
$0.0-4.8$
$0.0-2.5$
$0.0-2.9$

$(33.1)$
$(6.0)$
$(39.1)$
$(5.1)$
$(2.7)$
$(3.2)$

$\begin{array}{lll}0.0-21.6 & 10.0 & (29.2)\end{array}$

$4.3-16.1 \quad 11.9 \quad(34.8)$

$\begin{array}{lll}.9-2.9 & 1.6 & (4.7)\end{array}$

$0.0-5.3$

$\begin{array}{lll}0.0-2.9 & 1.0 & (2.8)\end{array}$

$0.0-6.9 \quad 2.4 \quad(6.8)$

$0.0-1.0$

$(1.8) \quad 91.0$

$\begin{array}{rrrr}0.0-2.4 & .9 & (2.7) & 86.2 \\ 0.0-3.2 & 1.0 & (3.0) & \\ 0.0-1.2 & .4 & (1.1) & \end{array}$

$0.0-.6 \quad 2.8$

$0.0-1.2 \quad .2 \quad(1.0)$

$0.0-1.2$
$0.0-\quad .4$

(1.3)

$0.0-.3$

$\left(\begin{array}{l}5) \\ (2.0)\end{array}\right.$

( 2.0$)$

$0.000-.121 \quad .035 \quad(1.2)$

$\begin{array}{lll}.033 & (1.1)\end{array}$

$0.000-.112$

$.022 \quad(.7)$

$0.000-.051 \quad .020 \quad\left(\begin{array}{lll}.76 \\ .016\end{array}\right.$

$0.0-.2$

$0.0-.1$

$\left(\begin{array}{ll}( & 3)\end{array}\right.$

$\begin{array}{ll}( & .8) \\ ( & .2)\end{array}$

$\left.\begin{array}{ll}( & .2) \\ ( & .1\end{array}\right)$

$\left(\begin{array}{ll}1 \\ ( & .1)\end{array}\right.$

$\left(\begin{array}{ll}.1 \\ ( \\ (1)\end{array}\right.$

$\left(\begin{array}{ll}.1 \\ (\quad .5)\end{array}\right.$

$\left(\begin{array}{r}0.0) \\ (.1)\end{array}\right.$

$\left(\begin{array}{rl}.1) \\ (0.0)\end{array}\right.$

$(0.0)$

$(0.0)$

$0.0-\quad .1$

$0.000-.036$

.007

$.006 \quad$ ( .2)

$.006 \quad\left(\begin{array}{ll}2 \\ .006\end{array}\right.$

$.006 \quad(.2)$

$.005 \quad(.2)$

$0.000-.025 \quad .005 \quad\left(\begin{array}{ll}.2) \\ .004\end{array}\right.$

$\left.\begin{array}{ll}( & 11 \\ ( & .1\end{array}\right)$

$.003 \quad(.1)$

(.

$\left(\begin{array}{l}1 \\ (.1)\end{array}\right.$

$\left.\begin{array}{ll}( & .1) \\ ( & .1\end{array}\right)$

( . .1)

$(0.0)$

$(0.0)$
$(0.0)$

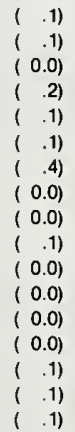

$\begin{array}{lll}0.0-1.2 & .4 & (1.1) \\ 0.0-1.0 & .2 & (.6) \\ 0.0-1.7 & .4 & (1.0)\end{array}$

$0.0-1.7 \quad .4 \quad(1.0)$

$0.0-2.0 \quad .3 \quad\left(\begin{array}{r}9 \\ .9\end{array}\right.$

(1.3)

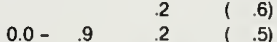

$(.5)$
$(.9)$

$(.9)$
$(7)$

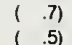

$\left(\begin{array}{l}.5 \\ (5)\end{array}\right.$

$\begin{array}{ll}( & .5 \\ ( & .4)\end{array}$

$\begin{array}{ll}( & 4) \\ ( & .4)\end{array}$

$(0.0)$

( .2)

(. .1)

$\left.\begin{array}{ll}( & .1 \\ ( & .2\end{array}\right)$

$\left(\begin{array}{r}.2) \\ (0.0)\end{array}\right.$

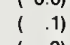

$\left(\begin{array}{ll}1 \\ ( & .2\end{array}\right)$

$(0.0)$

$(0.0)$
$(0.0)$

$\left(\begin{array}{ll}1 \\ \left(\begin{array}{l}1 \\ (\end{array}\right)\end{array}\right.$

$\left(\begin{array}{r}0.0) \\ (0.0)\end{array}\right.$

$(0.0)$

$(0.0)$

( 0.0$)$

$(0.0)$
$(0.0)$

$(0.0)$

$(0.0)$

$\begin{array}{rrr}0.0-100.0 & 47.5 & (13.0) \\ 35.0-90.0 & 59.2 & (16.2) \\ 30.0-70.0 & 47.5 & (13.0) \\ 0.0-60.0 & 25.0 & (6.8) \\ 0.0-90.0 & 36.7 & (10.0) \\ 0.0-35.0 & 15.0 & (4.1) \\ 0.0-60.0 & 25.8 & (7.1)\end{array}$

$\begin{array}{lll}0.0-60.0 & 25.8 & (4.1)\end{array}$

$0.0-40.0-15.0-(4.1)$

$\begin{array}{lll}0.0-40.0 & 15.0 & (4.1) \\ 0.0-45.0 & 15.0 & (4.1)\end{array}$

$\begin{array}{rrr}0.0-45.0 & 15.0 & (4.1) \\ 0.0-35.0 & 9.2 & (2.5)\end{array}$

$\begin{array}{rrr}0.0-35.0 & 9.2 & (2.5) \\ 0.0-30.0 & 10.0 & (2.7)\end{array}$

$0.0-20.0 \quad 1.7 \quad\left(\begin{array}{ll}.5) \\ 5.8\end{array}\right.$

$\begin{array}{ll}0.0-20.0 & 5.8 \\ 3.3 & (1.6)\end{array}$

$\begin{array}{lll}0.0-40.0 & 9.2 & (2.5)\end{array}$

$\begin{array}{rr}6.7 & (1.8) \\ 3.3 & (9)\end{array}$

$\begin{array}{lll}0.0-15.0 & 4.3 & \left(\begin{array}{r}.9 \\ 1.1\end{array}\right)\end{array}$

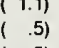

$\left(\begin{array}{l}( \\ (\end{array}\right)$
$(.5)$

$(.5)$
$(\quad .2)$
$(\quad .5)$

$\left.\begin{array}{ll}( & .5) \\ ( & .5\end{array}\right)$

$(.5)$
$(\quad .7)$

$\left(\begin{array}{ll}(.5) \\ (\text { ) }\end{array}\right.$

$(.5)$

$\left(\begin{array}{ll}1 \\ (\quad 5)\end{array}\right.$

( .5)

( .2)

$\left(\begin{array}{ll}.5) \\ (10.0)\end{array}\right.$

$\begin{array}{llll}0.0- & 0.0 & 0.0 & (0.0)\end{array}$

$\left(\begin{array}{l}.5) \\ (.2)\end{array}\right.$

$\left(\begin{array}{ll}.2) \\ (\quad .2)\end{array}\right.$

( .2)

( .2)

(.)

$(.2)$

( 0.0$)$

$(0.0)$

$\overline{2.999}$

24.8

34.3

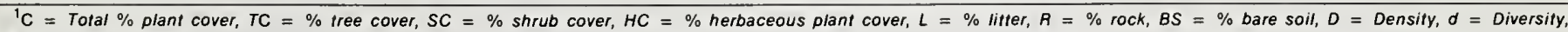
$S R=$ Species richness.

3 plant species symbol (see Appendix B for full nomenclature).

${ }^{4} K=$ Constancy.
${ }^{5} T P=$ Total percent for species with $I V \geqslant 0.1$. 
Table 19.-Vegetation and soil surface characteristics for plant community 14 (p.c.14).

COMMUNITY 14 : Artr/Spcr.Orhy

SITES 153

Mean ${ }^{1}$

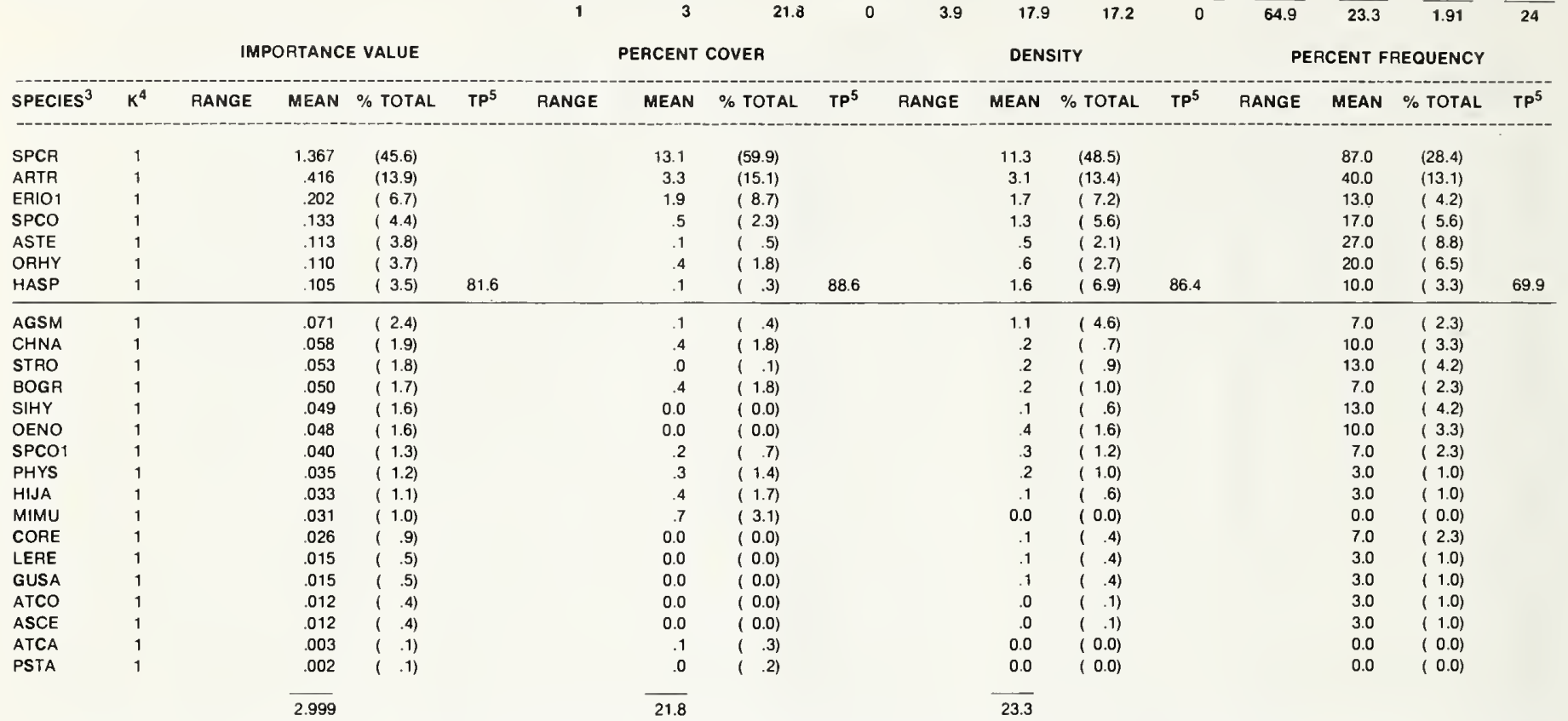

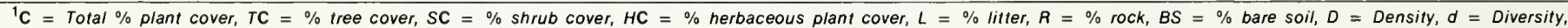
$S R=$ Species richness.

${ }^{3}$ Plant species symbol (see Appendix B for full nomenclature).

${ }_{5}^{4} K=$ Constancy

${ }^{5} T P=$ Total percent for species with $I V \geqslant 0.1$.

Table 20.-Vegetation and soil surface characteristics for plant community 15 (p.c.15).

Mean'

COMMUNITY 15 : Artr-ChpalArfe-Bogr

SITES $\quad 151$ $\begin{array}{llllllllllll}\text { No. Sites } & \text { No. Trans. } & \frac{C}{5} & \frac{\text { TC }}{17.3} & \frac{\text { SC }}{6} & \frac{H C}{11.2} & \frac{L}{17.7} & \frac{R}{0.5} & \frac{\text { BS }^{2}}{70.6} & \frac{D}{35.0} & \frac{d}{2.35} & \frac{\text { SR }}{24}\end{array}$ DENSITY

PERCENT FREQUENCY

\begin{tabular}{|c|c|c|c|c|c|c|c|c|c|c|c|c|c|c|c|c|c|}
\hline SPECIES ${ }^{3}$ & $K^{4}$ & RANGE & MEAN & $\%$ TOTAL & $T P^{5}$ & RANGE & MEAN & $\%$ TOTAL & $T P^{5}$ & RANGE & MEAN & $\%$ TOTAL & $T P^{5}$ & RANGE & MEAN & $\%$ TOTAL & $T P^{5}$ \\
\hline ARFE1 & 1 & & .649 & $(21.6)$ & & & 4.3 & (24.9) & & & 7.8 & (22.4) & & & 66.0 & $(17.6)$ & \\
\hline BOGR & 1 & & .364 & $(12.1)$ & & & 1.7 & (9.8) & & & 6.7 & (19.2) & & & 28.0 & $(7.5)$ & \\
\hline ARTR & 1 & & .348 & (11.6) & & & 3.1 & (18.1) & & & 3.2 & (9.1) & & & 28.0 & ( 7.5) & \\
\hline CHPA & 1 & & .303 & (10.1) & & & 2.7 & (15.8) & & & .8 & (2.2) & & & 46.0 & (12.3) & \\
\hline HIJA & 1 & & .231 & $(7.7)$ & & & 1.0 & ( 5.7$)$ & & & 3.8 & $(11.0)$ & & & 24.0 & (6.4) & \\
\hline SPA1 & 1 & & .166 & ( 5.5$)$ & & & 1.1 & (6.1) & & & 2.4 & $(6.7)$ & & & 14.0 & ( 3.7$)$ & \\
\hline SPCR & 1 & & .164 & (5.5) & & & .3 & $(1.8)$ & & & 1.7 & $(5.0)$ & & & 36.0 & (9.6) & \\
\hline MURI & 1 & & .140 & ( 4.7$)$ & & & .5 & ( 2.7$)$ & & & 2.8 & $(8.1)$ & & & 12.0 & (3.2) & \\
\hline ORHY & 1 & & .129 & (4.3) & & & .6 & ( 3.5$)$ & & & .9 & (2.5) & & & 26.0 & $(7.0)$ & \\
\hline AGSM & 1 & & .102 & ( 3.4$)$ & 86.5 & & .4 & ( 2.3$)$ & 85.3 & & 1.8 & ( 5.3$)$ & 91.5 & & 10.0 & ( 2.7$)$ & 83.5 \\
\hline CHVI2 & 1 & & .097 & (3.2) & & & .5 & ( 2.6$)$ & & & 6 & $(1.7)$ & & & 20.0 & ( 5.3$)$ & \\
\hline THME & 1 & & .064 & (2.1) & & & .1 & ( . .6) & & & 1.1 & (3.1) & & & 10.0 & ( 2.7$)$ & \\
\hline SIHY & 1 & & .062 & (2.1) & & & .2 & (1.1) & & & .3 & ( 8$)$ & & & 16.0 & ( 4.3) & \\
\hline SEMU1 & 1 & & .043 & (1.4) & & & .2 & (1.1) & & & .2 & ( . .5) & & & 10.0 & $(2.7)$ & \\
\hline OPPO & 1 & & .030 & $(1.0)$ & & & 0.0 & $(0.0)$ & & & .1 & (. .3) & & & 10.0 & $(2.7)$ & \\
\hline ASCE & 1 & & .029 & $(1.0)$ & & & 0.0 & $(0.0)$ & & & .4 & (1.3) & & & 6.0 & $(1.6)$ & \\
\hline SAVE & 1 & & .023 & $(.8)$ & & & .3 & $(1.7)$ & & & .0 & ( . .1) & & & 2.0 & $\left(\begin{array}{l}(.5) \\
(\end{array}\right)$ & \\
\hline EUPH & 1 & & .012 & (. .4) & & & 0.0 & $(0.0)$ & & & .1 & (. .2) & & & 4.0 & $(1.1)$ & \\
\hline SPDI & 1 & & .010 & ( . .3) & & & 0.0 & $(0.0)$ & & & .2 & ( . .5) & & & 2.0 & $(.5)$ & \\
\hline LEER & 1 & & .009 & (. .3) & & & .1 & (. .3) & & & .0 & ( . .1) & & & 2.0 & ( . .5) & \\
\hline DIST & 1 & & .008 & ( . .3) & & & .0 & (.1) & & & .1 & $($ ( . .2) & & & 2.0 & ( $\quad .5)$ & \\
\hline VEBR & 1 & & .006 & (. .2) & & & .1 & ( .6) & & & 0.0 & $(0.0)$ & & & 0.0 & $(0.0)$ & \\
\hline SCPA & 1 & & .006 & ( . .2) & & & .1 & ( . .6) & & & 0.0 & $(0.0)$ & & & 0.0 & $(0.0)$ & \\
\hline $\mathrm{SPCO} 2$ & 1 & & .005 & ( . .2) & & & .1 & ( .5) & & & 0.0 & $(0.0)$ & & & 0.0 & $(0.0)$ & \\
\hline & & & $\overline{3.000}$ & & & & 17.3 & & & & 35.0 & & & & & & \\
\hline
\end{tabular}

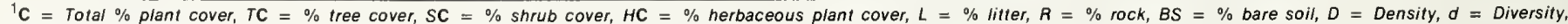
$S R=$ Species richness.

3 Plant species symbol (see Appendix B for full nomenclature).

${ }^{4} K=$ Constancy.

${ }^{4} K=$ Constancy.
${ }^{5} P=$ Total percent for species with $I V \geqslant 0.1$. 
Table 21. - Vegetation and soll surface characteristics for plant community 16 (p.c.16).

Mean ${ }^{1}$

COMMUNITY 16 : Arno-Artr/AgCr.Agsm

SITES 81

$\begin{array}{llllllllllllll}\text { No. Sites } & \text { No. Trans. } & \frac{C}{4} & \frac{\text { TC }}{21.2} & \frac{\mathrm{SC}}{0} & \frac{\mathrm{HC}}{15.7} & \frac{\mathrm{L}}{5.5} & \frac{\mathrm{R}}{6.8} & \frac{\text { BS }^{2}}{8} & \frac{\mathrm{D}}{28.3} & \frac{\mathrm{d}}{2.30} & \frac{\text { SA }}{23}\end{array}$

\begin{tabular}{|c|c|c|c|c|c|c|c|c|c|c|c|c|c|c|c|c|c|}
\hline \multirow[b]{2}{*}{ SPECIES ${ }^{3}$} & \multirow[b]{2}{*}{$k^{4}$} & \multicolumn{4}{|c|}{ IMPORTANCE VALUE } & \multicolumn{4}{|c|}{ PERCENT COVER } & \multicolumn{4}{|c|}{ DENSITY } & \multicolumn{4}{|c|}{ PERCENT FREQUENCY } \\
\hline & & RANGE & MEAN & $\%$ TOTAL & $T P^{5}$ & RANGE & MEAN & $\%$ TOTAL & $T P^{5}$ & RANGE & MEAN & $\%$ TOTAL & $T P^{5}$ & RANGE & MEAN & $\%$ TOTAL & $T P^{5}$ \\
\hline ARNO & 1 & & .667 & (22.2) & & & 8.7 & $(40.9)$ & & & 2.7 & (9.5) & & & 65.0 & $(16.0)$ & \\
\hline AGCR & 1 & & .524 & (17.5) & & & 1.5 & (6.8) & & & 8.1 & (28.6) & & & 68.0 & (16.7) & \\
\hline AGSM & 1 & & .371 & (12.4) & & & 1.2 & $(5.6)$ & & & 4.7 & (16.5) & & & 60.0 & (14.7) & \\
\hline ARTA & 1 & & .292 & (9.7) & & & 4.8 & (22.6) & & & .3 & ( . .9) & & & 23.0 & ( 5.7$)$ & \\
\hline BOGR & 1 & & .262 & ( 8.7$)$ & & & .7 & (3.1) & & & 4.2 & $(15.0)$ & & & 33.0 & (8.1) & \\
\hline GUSA & 1 & & .140 & ( 4.7$)$ & & & 1.0 & $(4.6)$ & & & .7 & $(2.5)$ & & & 28.0 & (6.9) & \\
\hline ERLO1 & 1 & & .136 & ( 4.5$)$ & 79.7 & & .8 & (3.8) & 87.0 & & 1.4 & ( 4.8$)$ & 27.8 & & 20.0 & ( 4.9$)$ & 73.0 \\
\hline CHDE & 1 & & .094 & (3.1) & & & 1.1 & ( 5.3$)$ & & & 3 & $(.9)$ & & & 13.0 & ( 3.2$)$ & \\
\hline ALCE & 1 & & .092 & (3.1) & & & .1 & ( .5) & & & 1.6 & $(5.6)$ & & & 13.0 & (3.2) & \\
\hline HYFI & 1 & & .049 & $(1.6)$ & & & .0 & $(.1)$ & & & .3 & ( 1.1$)$ & & & 15.0 & ( 3.7$)$ & \\
\hline SPHA & 1 & & .048 & ( 1.6$)$ & & & 0.0 & $(0.0)$ & & & .5 & ( 1.7$)$ & & & 13.0 & (3.2) & \\
\hline AGRO1 & 1 & & .042 & $(1.4)$ & & & .4 & $(1.8)$ & & & .5 & $(1.8)$ & & & 3.0 & $(.7)$ & \\
\hline MUHL & 1 & & .041 & ( 1.4$)$ & & & .1 & ( . .4) & & & .9 & (3.1) & & & 3.0 & $(.7)$ & \\
\hline SENE & 1 & & .037 & ( 1.2$)$ & & & .2 & $(8)$ & & & .3 & $(1.0)$ & & & 8.0 & $(2.0)$ & \\
\hline MURI1 & 1 & & .036 & $(1.2)$ & & & .2 & ( 1.1$)$ & & & 6 & ( 1.9$)$ & & & 3.0 & ( .7) & \\
\hline OPIM & 1 & & .034 & (1.1) & & & .1 & $(.5)$ & & & .1 & $\left(\begin{array}{l}(.5) \\
(\end{array}\right.$ & & & 10.0 & ( 2.5) & \\
\hline UNKF & 1 & & .033 & (1.1) & & & .1 & ( . .6) & & & .4 & $(1.5)$ & & & 5.0 & (1.2) & \\
\hline SIHY & 1 & & .032 & ( 1.1$)$ & & & .1 & ( . .4) & & & .3 & $(1.0)$ & & & 8.0 & $(2.0)$ & \\
\hline HIJA & 1 & & .031 & $(1.0)$ & & & .1 & ( . .2) & & & .5 & $(1.6)$ & & & 5.0 & $(1.2)$ & \\
\hline CAIN2 & 1 & & .015 & ( . .5) & & & 0.0 & $(0.0)$ & & & .1 & ( . .3) & & & 5.0 & $(1.2)$ & \\
\hline ORHY & 1 & & .014 & ( . .5) & & & .1 & ( . .6) & & & .1 & ( , 2) & & & 3.0 & ( . .7) & \\
\hline CHNA & 1 & & .008 & ( . .3) & & & 0.0 & $(0.0)$ & & & .1 & $\left(\begin{array}{l}(.2) \\
(\end{array}\right.$ & & & 3.0 & $(.7)$ & \\
\hline SCPA & 1 & & .002 & ( . .1) & & & .1 & ( .2) & & & 0.0 & $(0.0)$ & & & 0.0 & $(0.0)$ & \\
\hline & & & 3.000 & & & & 21.2 & & & & 28.3 & & & & & & \\
\hline
\end{tabular}

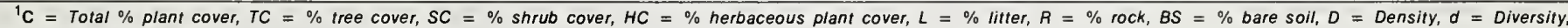
$S R_{2}=$ Species richness.

3 plant species symbol (see Appendix B for full nomenclature).

${ }^{4} \mathrm{~K}=$ Constancy.

${ }^{5} K P=$ Constancy.
${ }_{T P}=$ Total percent for species with $I V \geqslant 0.1$

Table 22.-Vegetation and soil surface characteristics for plant community 17 (p.c.17)

COMMUNITY $17:$ Arno.Gusa/Bogr.Hlja SITES

38

Mean ${ }^{1}$

\begin{tabular}{|c|c|c|c|c|c|c|c|c|c|c|c|c|c|c|c|c|c|}
\hline \multirow[b]{2}{*}{ SPECIES $^{3}$} & \multicolumn{5}{|c|}{ IMPORTANCE VALUE } & \multicolumn{4}{|c|}{ PERCENT COVER } & \multicolumn{4}{|c|}{ DENSITY } & \multicolumn{4}{|c|}{ PERCENT FREOUENCY } \\
\hline & $k^{4}$ & RANGE & MEAN & $\%$ TOTAL & $T P^{5}$ & RANGE & MEAN & $\%$ TOTAL & $T P^{5}$ & RANGE & MEAN & $\%$ TOTAL & $T P^{5}$ & RANGE & MEAN & $\%$ TOTAL & $T P^{5}$ \\
\hline BOGR & 1 & & 1.321 & (44.1) & & & 2.8 & (23.4) & & & 22.4 & (77.6) & & & 90.0 & (31.0) & \\
\hline GUSA & 1 & & .377 & (12.6) & & & 2.9 & (24.3) & & & .9 & ( 3.1$)$ & & & 30.0 & $(10.3)$ & \\
\hline ARNO & 1 & & .370 & (12.3) & & & 3.0 & $(25.1)$ & & & .5 & ( 1.6$)$ & & & 30.0 & (10.3) & \\
\hline HIJA & 1 & & .281 & (9.4) & & & .6 & ( 4.6$)$ & & & 2.8 & ( 9.7) & & & 40.0 & (13.8) & \\
\hline ERIO1 & 1 & & .127 & ( 4.2) & & & .8 & ( 6.7$)$ & & & .3 & $\left(\begin{array}{l}\text { ( } .9) \\
\text { ( }\end{array}\right.$ & & & 15.0 & ( 5.2$)$ & \\
\hline LEPU & 1 & & .109 & (3.6) & 86.2 & & .2 & ( 1.3$)$ & 85.4 & & .8 & $(2.8)$ & 95.7 & & 20.0 & (6.9) & 77.5 \\
\hline UNK9 & 1 & & .092 & $(3.1)$ & & & .4 & ( 3.3$)$ & & & .2 & $(.7)$ & & & 15.0 & $(5.2)$ & \\
\hline HASP2 & 1 & & .090 & ( 3.0$)$ & & & .1 & ( .4) & & & .5 & ( 1.7$)$ & & & 20.0 & ( 6.9$)$ & \\
\hline SIHY & 1 & & .069 & ( 2.3) & & & .1 & $(.8)$ & & & .3 & $(.9)$ & & & 15.0 & ( 5.2$)$ & \\
\hline ARLO1 & 1 & & .068 & ( 2.3) & & & .3 & ( 2.5$)$ & & & .3 & ( .9) & & & 10.0 & $(3.4)$ & \\
\hline CHNA & 1 & & .042 & ( 1.4) & & & .5 & ( 4.2) & & & 0.0 & $(0.0)$ & & & 0.0 & $(0.0)$ & \\
\hline MUWR & 1 & & .021 & $(.7)$ & & & .3 & ( 2.1) & & & 0.0 & $(0.0)$ & & & 0.0 & $(0.0)$ & \\
\hline ARAB & 1 & & .019 & ( . .6) & & & 0.0 & $(0.0)$ & & & .1 & ( . .2) & & & 5.0 & $(1.7)$ & \\
\hline MUMO1 & 1 & & .008 & ( . .3) & & & .1 & ( . .8) & & & 0.0 & $(0.0)$ & & & 0.0 & $(0.0)$ & \\
\hline KOCR & 1 & & .004 & ( .1) & & & .1 & ( . .4) & & & 0.0 & $(0.0)$ & & & 0.0 & $(0.0)$ & \\
\hline & & & $\overline{2.998}$ & & & & 12.0 & & & & 28.9 & & & & & & \\
\hline
\end{tabular}

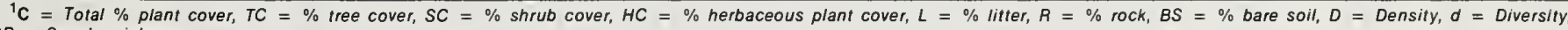
$S R=$ Species richness.

$B S=100-(H C+L+R)$.

${ }^{3}$ Plant species symbol (see Appendix B for full nomenclature).

${ }_{5}^{4} K=$ Constancy.

${ }^{5} T P=$ Total percent for species with $I V \geqslant 0.1$. 
Table 23. - Vegetation and soil surface characteristics for plant community 18 (p.c.18).

Mean'

COMMUNITY 18 : Chnab/Bogr.Agsm

SITES $\quad 136$

$\begin{array}{llllllllllllllll}\text { No. Sites } & \text { No. Trans. } & \text { C } & \text { C } & \frac{T C}{37.7} & \frac{\text { SC }}{0} & \frac{H C}{8.1} & \frac{H C}{29.6} & \frac{L}{16.3} & \frac{R}{0.1} & \frac{B^{2}}{54.0} & \frac{D}{37.3} & \frac{d}{1.47} & \frac{S R}{18}\end{array}$

IMPORTANCE VALUE

PERCENT COVER

DENSITY

PERCENT FREQUENCY

\begin{tabular}{|c|c|c|c|c|c|c|c|c|c|c|c|c|c|c|c|c|c|}
\hline SPECIES $^{3}$ & $k^{4}$ & RANGE & MEAN & $\%$ TOTAL & $T P^{5}$ & RANGE & MEAN & $\%$ TOTAL & $T P^{5}$ & RANGE & MEAN & $\%$ TOTAL & $T P^{5}$ & RANGE & MEAN & $\%$ TOTAL & $T P^{5}$ \\
\hline BOGR & 1 & & 1.373 & (45.8) & & & 24.4 & $(64.7)$ & & & 16.6 & $(44.6)$ & & & 80.0 & (28.1) & \\
\hline AGSM & 1 & & .550 & (18.3) & & & 2.0 & (5.3) & & & 12.0 & (32.1) & & & 50.0 & (17.5) & \\
\hline HIJA & 1 & & .229 & $(7.6)$ & & & 1.3 & $(3.4)$ & & & 4.0 & (10.7) & & & 25.0 & ( 8.8$)$ & \\
\hline SPCR & 1 & & .186 & (6.2) & & & .6 & $(1.6)$ & & & 1.8 & ( 4.7$)$ & & & 35.0 & (12.3) & \\
\hline CHNA & 1 & & .138 & $(4.6)$ & & & 5.2 & (13.8) & & & 0.0 & $(0.0)$ & & & 0.0 & $(0.0)$ & \\
\hline ARFE1 & 1 & & .100 & ( 3.3$)$ & 85.8 & & .6 & $(1.5)$ & 90.3 & & .6 & ( 1.5$)$ & 93.6 & & 20.0 & $(7.0)$ & 73.7 \\
\hline CHPA & 1 & & .093 & $(3.1)$ & & & 1.3 & $(3.4)$ & & & .3 & $(.7)$ & & & 15.0 & $(5.3)$ & \\
\hline GUSA & 1 & & .077 & ( 2.6$)$ & & & .5 & $(1.2)$ & & & .5 & $(1.2)$ & & & 15.0 & ( 5.3$)$ & \\
\hline ARTR & 1 & & .071 & (2.4) & & & 1.1 & ( 2.9$)$ & & & .3 & ( . .7) & & & 10.0 & ( 3.5$)$ & \\
\hline AGDE & 1 & & .060 & $(2.0)$ & & & .1 & ( . .3) & & & .8 & ( 2.1) & & & 10.0 & ( 3.5$)$ & \\
\hline SIHY & 1 & & .025 & $(.8)$ & & & .0 & ( . .1) & & & .3 & $(.7)$ & & & 5.0 & $(1.8)$ & \\
\hline MURI1 & 1 & & .023 & ( .8$)$ & & & 0.0 & $(0.0)$ & & & .2 & ( . .5) & & & 5.0 & ( 1.8$)$ & \\
\hline ARLO1 & 1 & & .020 & $(.7)$ & & & 0.0 & $(0.0)$ & & & .1 & ( . .3) & & & 5.0 & $(1.8)$ & \\
\hline SCPA & 1 & & .019 & ( . .6) & & & 0.0 & $(0.0)$ & & & .1 & ( .1) & & & 5.0 & $(1.8)$ & \\
\hline GRIN & 1 & & .019 & ( . .6) & & & 0.0 & $(0.0)$ & & & .1 & ( .1$)$ & & & 5.0 & $(1.8)$ & \\
\hline SPIN & 1 & & .009 & ( . .3) & & & .4 & ( . .9) & & & 0.0 & $(0.0)$ & & & 0.0 & $(0.0)$ & \\
\hline SPHA & 1 & & .007 & 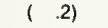 & & & .3 & $(.7)$ & & & 0.0 & $(0.0)$ & & & 0.0 & $(0.0)$ & \\
\hline ORHY & 1 & & .001 & $(0.0\rangle$ & & & .1 & ( . .1) & & & 0.0 & $(0.0)$ & & & 0.0 & $(0.0)$ & \\
\hline & & & 3.000 & & & & 37.7 & & & & 37.3 & & & & & & \\
\hline
\end{tabular}

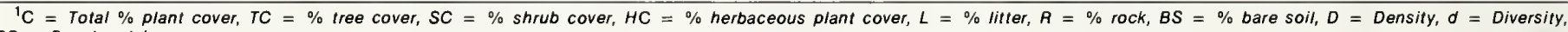
$S R_{2 B S}=100-1 H C+1$

${ }^{2} B S=100-(H C+L+A)$.

${ }_{4}^{3}$ Plant species symbol (see Appendix B for full nomenclature).

${ }_{5}^{4} K=$ Constancy.

${ }^{5} T P=$ Total percent for species with $N \geqslant 0.1$.

Table 24. - Vegetation and soil surface characteristics for plant community 19 (p.c.19).

COMMUNITY 19 : Chpa/Hija·Bogr

$\begin{array}{llll}\text { SITES } & 77 & 134 & 135\end{array}$

Mean ${ }^{1}$

\begin{tabular}{|c|c|c|c|c|c|c|c|c|c|c|c|c|c|c|c|c|c|}
\hline \multirow[b]{2}{*}{ SPECIES $^{3}$} & \multirow[b]{2}{*}{$K^{4}$} & \multicolumn{4}{|c|}{ IMPORTANCE VALUE } & \multicolumn{4}{|c|}{ PERCENT COVER } & \multicolumn{4}{|c|}{ DENSITY } & \multicolumn{4}{|c|}{ PERCENT FREQUENCY } \\
\hline & & RANGE & MEAN & $\%$ TOTAL & $T P^{5}$ & RANGE & MEAN & $\%$ TOTAL & $T P^{5}$ & RANGE & MEAN & $\%$ TOTAL & $T P^{5}$ & RANGE & MEAN & $\%$ TOTAL & $T P^{5}$ \\
\hline BOGR & 3 & $.338-1.962$ & .997 & (33.2) & & $3.5-16.9$ & 9.5 & (35.2) & & $5.3-110.3$ & 41.6 & $(55.5)$ & & $40.0-95.0$ & 61.7 & $(20.4)$ & \\
\hline HIJA & 3 & $.162-.897$ & .615 & $(20.5)$ & & $.9-9.5$ & 5.0 & (18.3) & & $3.1-20.3$ & 12.9 & $(17.2)$ & & $23.0-90.0$ & 64.3 & (21.3) & \\
\hline AGSM & 3 & $.015-.562$ & .320 & (10.7) & & $.1-4.2$ & 1.5 & $(5.7)$ & & $.0-15.4$ & 8.8 & (11.8) & & $3.0-60.0$ & 34.3 & (11.3) & \\
\hline SPAI & 3 & $.001-.481$ & .201 & ( 6.7$)$ & & $.0-4.2$ & 2.2 & $(8.1)$ & & $0.0-5.0$ & 2.0 & (2.7) & & $0.0-60.0$ & 23.3 & ( 7.7$)$ & \\
\hline CHPA & 3 & $.152-.340$ & .188 & (11.4) & & $2.9-4.6$ & 2.9 & $(21.5)$ & & $.2-$ & .4 & $(.7)$ & & $10.0-40.0$ & 23.3 & $(11.0)$ & \\
\hline MURI1 & 2 & $0.000-.548$ & .187 & $(6.2)$ & & $0.0-5.4$ & 1.8 & $(6.6)$ & & $0.0-14.0$ & 4.7 & $(6.2)$ & & $0.0-50.0$ & 17.7 & $(5.8)$ & \\
\hline SPCR & 3 & $.074-.168$ & .116 & ( 3.9$)$ & 92.6 & $.2-1.1$ & .6 & $(2.0)$ & 97.4 & $.4-\quad 2.7$ & 1.3 & $(1.8)$ & 95.9 & $20.0-20.0$ & 20.0 & ( 6.6$)$ & 86.1 \\
\hline MUTO & 2 & $0.000-.058$ & .033 & $(1.1)$ & & $0.0-.1$ & .1 & $(.2)$ & & $0.0-\quad 5.3$ & 2.0 & $(2.6)$ & & $0.0-10.0$ & 4.3 & $(1.4)$ & \\
\hline SPDI & 2 & $0.000-.066$ & .022 & $(.7)$ & & $0.0-.9$ & .3 & (1.2) & & $0.0-$ & .2 & ( . .2) & & $0.0-10.0$ & 3.3 & $(1.1)$ & \\
\hline ARLO1 & 1 & & .022 & $(.7)$ & & & .1 & $(.5)$ & & & .2 & (. .2) & & & 3.3 & ( 1.1$)$ & \\
\hline OPIM & 2 & $0.000-.036$ & .022 & $(.7)$ & & $0.0-0.0$ & 0.0 & $(0.0)$ & & $0.0-$ & .1 & (.1) & & $0.0-10.0$ & 6.7 & ( 2.2) & \\
\hline $\mathrm{MACH}$ & 1 & & .017 & ( . .6) & & & .0 & (. .1) & & & .1 & (. .1) & & & 3.3 & $(1.1)$ & \\
\hline CELA & 1 & & .013 & ( . 4) & & & 0.0 & $(0.0)$ & & & .1 & ( . .2) & & & 3.3 & $(1.1)$ & \\
\hline ORHY & 1 & & .013 & (. .4) & & & 0.0 & $(0.0)$ & & & .1 & $(. .1)$ & & & 3.3 & $\langle 1.1\rangle$ & \\
\hline GRAP & 1 & & .012 & (.4) & & & .1 & (. .2) & & & .1 & (1. 1) & & & 3.3 & $(1.1)$ & \\
\hline LEER & 1 & & .012 & $(.4)$ & & & 0.0 & $(0.0)$ & & & .1 & (.1) & & & 3.3 & $(1.1)$ & \\
\hline HASP & 1 & & .012 & $(.4)$ & & & .0 & $(0.0)$ & & & .1 & $(.2)$ & & & 3.3 & $\langle 1.1\rangle$ & \\
\hline SPHA & 1 & & .010 & ( .3) & & & 0.0 & $(0.0)$ & & & .0 & $(0.0)$ & & & 3.3 & $\langle 1.1\rangle$ & \\
\hline CRFU & 1 & & .009 & ( . .3) & & & .0 & ( . .1) & & & .1 & ( .1) & & & 1.7 & $\left(\begin{array}{l}(.6) \\
(\mathrm{n})\end{array}\right.$ & \\
\hline SIHY & 2 & $0.000-.026$ & .009 & ( . .3) & & $0.0-.1$ & .0 & (.1) & & $0.0-$ & .0 & $(0.0)$ & & $0.0-5.0$ & 1.7 & ( . .6) & \\
\hline ERIO1 & 1 & & .008 & ( . .3) & & & .0 & $(0.0)$ & & & .0 & $(0.0)$ & & & 1.7 & (. .6) & \\
\hline ARTR & 1 & & .007 & ( . .2) & & & .1 & ( . .3) & & & .0 & $(0.0)$ & & & 1.0 & ( . .3) & \\
\hline UNKF & 1 & & .004 & (.1) & & & 0.0 & $(0.0)$ & & & .0 & $(0.0)$ & & & 1.0 & ( . .3) & \\
\hline & & & 3.001 & & & & 27.1 & & & & 75.0 & & & & & & \\
\hline
\end{tabular}

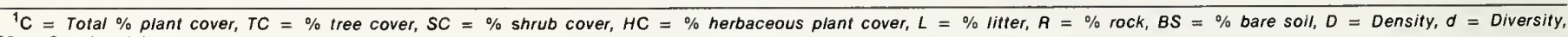
$S A_{2}=$ Species richness.

3 Plant species symbol (see Appendix B for full nomenclature).

${ }^{4} K=$ Constancy.

${ }^{5} \mathrm{TP}=$ Total percent for species with $\mathrm{N} \geqslant 0.1$. 
Table 25.-Vegetation and soil surface characteristics for plant community 20 (p.c.20).

$\operatorname{Mean}^{1}$

COMMUNITY 20: Chnag/Bogr.Agsm

SITES

133
IMPORTANCE VALUE

$\begin{array}{lllllllllllll}\text { No. Sites } & \text { No. Trans. } & \frac{C}{1} & \frac{T C}{49.5} & \frac{\text { SC }}{0} & \frac{H C}{9.0} & \frac{\mathrm{H}}{40.5} & \frac{\mathrm{l}}{24.1} & \frac{\mathrm{R}}{0} & \frac{\text { BS }^{2}}{35.4} & \frac{D}{29.5} & \frac{d}{0.74} & \frac{\text { SR }}{7}\end{array}$
DENSITY

\begin{tabular}{|c|c|c|c|c|c|c|c|c|c|c|c|c|c|c|c|c|c|}
\hline \multirow[b]{2}{*}{ SPECIES $^{3}$} & \multicolumn{5}{|c|}{ IMPORTANCE VALUE } & \multicolumn{4}{|c|}{ PERCENT COVER } & \multicolumn{4}{|c|}{ DENSITY } & \multicolumn{4}{|c|}{ PERCENT FREOUENCY } \\
\hline & $K^{4}$ & RANGE & MEAN & $\%$ TOTAL & $T P^{5}$ & RANGE & MEAN & $\%$ TOTAL & $T P^{5}$ & RANGE & MEAN & $\%$ TOTAL & $T P^{5}$ & RANGE & MEAN & $\%$ TOTAL & $T P^{5}$ \\
\hline BOGR & 1 & & 2.100 & $(70.0)$ & & & 37.2 & $(75.1)$ & & & 22.1 & (74.9) & & & 90.0 & $(60.0)$ & \\
\hline AGSM & 1 & & .357 & (11.9) & & & 2.0 & $(4.0)$ & & & 5.4 & (18.3) & & & 20.0 & (13.3) & \\
\hline SPCR & 1 & & .272 & (9.1) & & & .9 & ( 1.8$)$ & & & 1.6 & ( 5.4) & & & 30.0 & $(20.0)$ & \\
\hline CHNAG & 1 & & .174 & ( 5.8$)$ & 96.8 & & 8.6 & $(17.4)$ & 98.3 & & 0.0 & $(0.0)$ & 98.6 & & 0.0 & $(0.0)$ & 93.3 \\
\hline MURI1 & 1 & & .080 & (2.7) & & & 0.0 & $(0.0)$ & & & .4 & $(1.4)$ & & & 10.0 & (6.7) & \\
\hline SPHA & 1 & & .010 & $(.3)$ & & & .5 & $(1.0)$ & & & 0.0 & $(0.0)$ & & & 0.0 & $(0.0)$ & \\
\hline ARTR & 1 & & .007 & $(.2)$ & & & .4 & $(.7)$ & & & 0.0 & $(0.0)$ & & & 0.0 & $(0.0)$ & \\
\hline & & & $\overline{3.000}$ & & & & 49.5 & & & & 29.5 & & & & & & \\
\hline
\end{tabular}

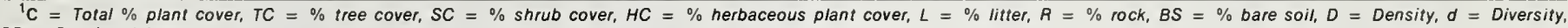
$S R_{2}=$ Species richness.

$B S=100-(H C+L+R)$

3 Plant species symbol (see Appendix B for full nomenclature)

$K=$ Constancy.

${ }_{T P}=$ Total percent for species with $I V \geqslant 0.1$.

Table 26. - Vegetation and soil surface characteristics for plant community 21 (p.c.21).

$\operatorname{Mean}^{1}$

COMMUNITY 21 : Save

SITES $\quad 12 \quad 78$

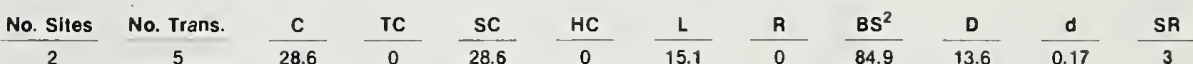

IMPORTANCE VALUE PERCENT COVER

DENSITY PERCENT FREQUENCY

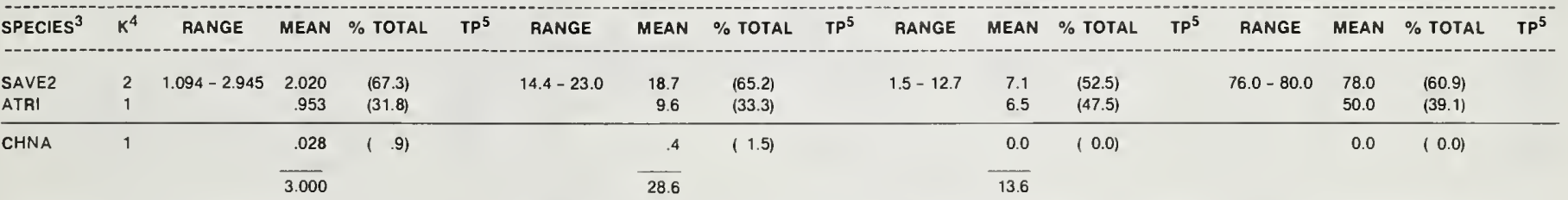

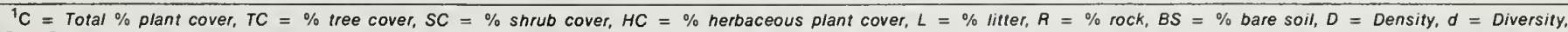
$S R=$ Species richness.

3 Plant species symbol (see Appendix B for full nomenclature).

${ }^{4} K=$ Constancy

${ }^{5} T P=$ Total percent for species with $I V \geqslant 0.1$.

Table 27. - Vegetation and soil surface characteristics for plant community 22 (p.c.22)

Mean'

COMMUNITY 22 : Save/SIhy.Agsm

SITES $\quad 150$

$\begin{array}{llllllllllllll}\text { No. Sltes } & \text { No. Trans. } & \frac{C}{5} & \frac{T C}{15.0} & \frac{\text { SC }}{9} & \frac{H C}{6.0} & \frac{L}{8.7} & \frac{R}{0} & \frac{B^{2}}{85.3} & \frac{D}{28.8} & \frac{d}{1.09} & \frac{\text { SR }}{9}\end{array}$

DENSITY

PERCENT FREQUENCY

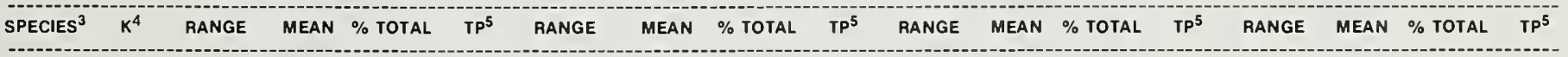

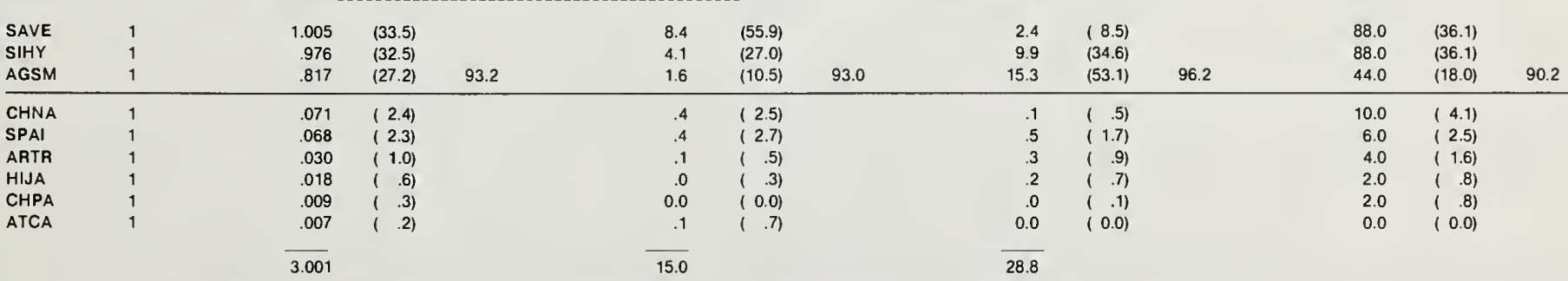

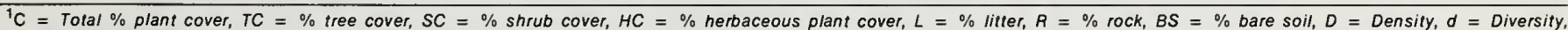
$S R=$ Species richness.

3 Plant species symbol (see Appendix B for full nomenclature)

${ }^{4} K=$ Constancy.

${ }^{5} T P=$ Total percent for species with $I V \geqslant 0.1$. 
Table 28. - Vegetation and soil surface characteristics for plant community 23 (p.c.23).

Mean'

COMMUNITY 23 : Cela.Gusa/Hija

SITES

$\begin{array}{lllllll}48 & 56 & 73 & 74 & 75 & 138 & 147\end{array}$

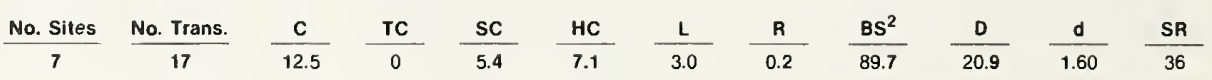

IMPORTANCE VALUE

PERCENT COVER

DENSITY

PERCENT FREOUENCY

\begin{tabular}{|c|c|c|c|c|c|c|c|c|c|c|c|c|c|c|c|c|c|}
\hline SPECIES ${ }^{3}$ & $k^{4}$ & RANGE & MEAN & $\%$ TOTAL & $T P^{5}$ & RANGE & MEAN & $\%$ TOTAL & $T P^{5}$ & RANGE & MEAN & $\%$ TOTAL & $T P^{5}$ & RANGE & MEAN & $\%$ TOTAL & $T P^{5}$ \\
\hline HIJA & 7 & $.739-1.591$ & 1.147 & $(38.3)$ & & $1.7-6.5$ & 4.0 & (31.9) & & $6.7-17.3$ & 11.8 & $(56.4)$ & & $60.0-90.0$ & 76.7 & (23.8) & \\
\hline GUSA & 7 & $.197-.823$ & .519 & (17.3) & & $.4-7.2$ & 3.4 & (27.6) & & $1.4-3.2$ & 2.2 & $(10.4)$ & & $20.0-77.0$ & 59.1 & (18.4) & \\
\hline CELA & 7 & $.111-.556$ & .300 & $(10.0)$ & & $.3-3.4$ & 1.7 & (13.3) & & $.4-2.0$ & .9 & (4.2) & & $13.0-73.0$ & 34.4 & (10.7) & \\
\hline SPAI & 5 & $0.000-.485$ & .140 & $(4.7)$ & & $0.0-3.5$ & .8 & ( 6.6) & & $0.0-2.3$ & .6 & (2.9) & & $0.0-30.0$ & 11.4 & ( 3.5$)$ & \\
\hline SIHY & 7 & $.037-.336$ & .137 & $(4.6)$ & & $0.0-.8$ & .2 & (1.2) & & $.1-1.8$ & .7 & (3.3) & & $10.0-83.0$ & 31.6 & (9.8) & \\
\hline$B O G R$ & 7 & $.069-.185$ & .115 & ( 3.8$)$ & & $.0-1.3$ & .4 & (3.2) & & $.6-1.7$ & .9 & (4.5) & & $3.0-40.0$ & 12.3 & ( 3.8$)$ & \\
\hline ORHY & 6 & $0.000-.279$ & .101 & ( 3.4$)$ & 82.1 & $0.0-1.0$ & .3 & ( 2.4$)$ & 86.2 & $0.0-1.2$ & .4 & $(2.1)$ & 83.8 & $0.0-53.0$ & 16.1 & $(5.0)$ & 77.0 \\
\hline SPCR & 6 & $0.000-.181$ & .086 & ( 2.9$)$ & & $0.0-.3$ & .1 & (1.1) & & $0.0-1.3$ & .4 & $(2.0)$ & & $0.0-35.0$ & 18.9 & ( 5.9$)$ & \\
\hline MUTO & 5 & $0.000-.169$ & .073 & ( 2.4$)$ & & $0.0-.3$ & .2 & ( 1.2$)$ & & $0.0-2.3$ & .8 & $(3.7)$ & & $0.0-17.0$ & 8.9 & ( 2.7$)$ & \\
\hline SPNE1 & 1 & & .064 & ( 2.1$)$ & & & .5 & $(4.1)$ & & & .3 & (1.5) & & & 4.3 & $(1.3)$ & \\
\hline UNKF & 4 & $0.000-.175$ & .055 & ( 1.8$)$ & & $0.0-.5$ & .1 & (1.1) & & $0.0-1.9$ & 5 & (2.6) & & $0.0-15.0$ & 5.9 & $(1.8)$ & \\
\hline SPHA & 5 & $0.000-.108$ & .052 & $(1.7)$ & & $0.0-.2$ & .1 & ( .6) & & $0.0-1.0$ & .4 & $(1.8)$ & & $0.0-23.0$ & 9.3 & ( 2.9$)$ & \\
\hline ARLO1 & 3 & $0.000-.117$ & .043 & $(1.4)$ & & $0.0-.3$ & .1 & $(.7)$ & & $0.0-1.3$ & .3 & (1.6) & & $0.0-23.0$ & 7.6 & ( 2.3$)$ & \\
\hline LEER & 2 & $0.000-.149$ & .027 & ( .9) & & $0.0-.9$ & .1 & $(1.0)$ & & $0.0-.9$ & .2 & ( .9) & & $0.0-13.0$ & 2.6 & ( . .8) & \\
\hline ARTR & 1 & & .018 & $(6)$ & & & .1 & $(1.2)$ & & & .0 & (. .1) & & & 1.4 & (. .4) & \\
\hline HASP2 & 1 & & .014 & ( . .5) & & & .0 & (.4) & & & .1 & (. .3) & & & 2.4 & $(.8)$ & \\
\hline SPDI & 1 & & .012 & ( . .4) & & & 0.0 & $(0.0)$ & & & .1 & ( . .2) & & & 2.1 & ( . .7) & \\
\hline OPPO & 3 & $0.000-.044$ & .010 & ( . .3) & & $0.0-.1$ & .0 & ( . .1) & & $0.0-.1$ & .0 & $(.1)$ & & $0.0-10.0$ & 2.3 & $(.7)$ & \\
\hline SPCO & 2 & $0.000-.035$ & .009 & ( . .3) & & $0.0-.2$ & .0 & $(.2)$ & & $0.0-.1$ & .0 & (.1) & & $0.0-10.0$ & 2.1 & ( . .7) & \\
\hline OPIM & 3 & $0.000-.033$ & .009 & ( . .3) & & $0.0-.3$ & .1 & ( .5) & & $0.0-.1$ & .0 & $(0.0)$ & & $0.0-5.0$ & .7 & $(.2)$ & \\
\hline STNE & 2 & $0.000-.033$ & .008 & $(.3)$ & & $0.0=.1$ & .0 & ( .1) & & $0.0-.2$ & .0 & $(.2)$ & & $0.0-7.0$ & 2.0 & $($ ( .6) & \\
\hline ASTR & 2 & $0.000-.034$ & .007 & ( . .2) & & $0.0-.0$ & .0 & $(0.0)$ & & $0.0-.1$ & .0 & (.1) & & $0.0-10.0$ & 1.9 & ( .6) & \\
\hline ERIO1 & 1 & & .006 & ( . .2) & & & .0 & $(0.0)$ & & & .0 & $(.1)$ & & & 1.0 & $(.3)$ & \\
\hline HASP & 1 & & .005 & ( . .2) & & & 0.0 & $(0.0)$ & & & .0 & (.1) & & & 1.4 & $(.4)$ & \\
\hline ARBI2 & 1 & & .005 & ( . .2) & & & 0.0 & $(0.0)$ & & & .0 & (.1) & & & 1.4 & $(.4)$ & \\
\hline YUGL & 2 & $0.000-.030$ & .005 & ( . .2) & & $0.0-.4$ & .1 & ( .4) & & $0.0-0.0$ & 0.0 & $(0.0)$ & & $0.0-0.0$ & 0.0 & $(0.0)$ & \\
\hline SOLA & 1 & & .005 & ( . .2) & & & 0.0 & $(0.0)$ & & & .0 & $(.2)$ & & & 1.0 & ( . .3) & \\
\hline ARBI & 1 & & .005 & ( . .2) & & & .0 & ( . .3) & & & 0.0 & $(0.0)$ & & & 0.0 & $(0.0)$ & \\
\hline BOER1 & 1 & & .004 & ( .1) & & & 0.0 & $(0.0)$ & & & .0 & $(.2)$ & & & 1.0 & ( .3) & \\
\hline ATCO & 1 & & .004 & (.1) & & & 0.0 & $(0.0)$ & & & .0 & $(0.0)$ & & & .7 & $(.2)$ & \\
\hline ARNO & 1 & & .004 & (.1) & & & .0 & $(.1)$ & & & .0 & $(0.0)$ & & & .4 & ( .1) & \\
\hline $\mathrm{OPCL}$ & 2 & $0.000-.015$ & .003 & ( . .1) & & $0.0-.1$ & .0 & (.1) & & $0.0-.0$ & .0 & $(0.0)$ & & $0.0-3.0$ & .4 & ( . .1) & \\
\hline ATCA & 2 & $0.000-.010$ & .003 & (.1) & & $0.0=.2$ & .0 & (. .3) & & $0.0-0.0$ & 0.0 & $(0.0)$ & & $0.0-0.0$ & 0.0 & $(0.0)$ & \\
\hline FRJA & 1 & & .002 & (. .1) & & & .0 & (. .1) & & & 0.0 & $(0.0)$ & & & 0.0 & $(0.0)$ & \\
\hline BOER & 1 & & .002 & $(.1)$ & & & 0.0 & $(0.0)$ & & & .0 & $(0.0)$ & & & .4 & ( . .1) & \\
\hline \multirow[t]{2}{*}{ covi } & 1 & & .001 & $(0.0)$ & & & 0.0 & $(0.0)$ & & & .0 & $(0.0)$ & & & .4 & $(.1)$ & \\
\hline & & & 2.998 & & & & 12.5 & & & & 20.9 & & & & & & \\
\hline
\end{tabular}

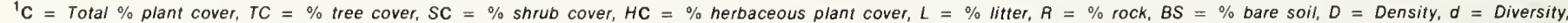
$S R_{2}=$ Species richness

3 Plant species symbol (see Appendix B for tull nomenclature).

${ }^{4} \mathrm{~K}=$ Constancy.

${ }_{5} K=$ Constancy. 
Table 29. - Vegetation and soil surface characteristics for plant community 24 (p.c.24).

Mean $^{1}$

COMMUNITY 24 : Cela.Gusa/Bogr

SITES

$\begin{array}{lll}50 & 55 & 158\end{array}$ $\frac{\text { No. Sites }}{3} \quad \frac{\text { No. Trans. }}{9}$

PERCENT COVER

IMPORTANCE VALUE

\begin{tabular}{|c|c|c|c|c|c|c|c|c|c|}
\hline c & TC & sc & $\mathrm{HC}$ & $\mathbf{L}$ & R & $\mathrm{BS}^{2}$ & D & d & SR \\
\hline 14.9 & 0 & 2.9 & 12.0 & 3.5 & 0 & 84.5 & 42.0 & 1.09 & 29 \\
\hline
\end{tabular}

\begin{tabular}{|c|c|c|c|c|c|c|c|c|c|c|c|c|c|c|c|c|c|}
\hline SPECIES ${ }^{3}$ & $K^{4}$ & RANGE & MEAN & $\%$ TOTAL & $T P^{5}$ & RANGE & MEAN & $\%$ TOTAL & $T P^{5}$ & RANGE & MEAN & $\%$ TOTAL & $T P^{5}$ & RANGE & MEAN & $\%$ TOTAL & $T P^{5}$ \\
\hline BOGR & 3 & $1.182-1.694$ & 1.400 & $(46.7)$ & & $4.9-13.2$ & 7.8 & (52.3) & & $16.0-45.7$ & 28.0 & $\langle 66.6\rangle$ & & $60.0-90.0$ & 73.3 & $(24.9)$ & \\
\hline HIJA & 3 & $.547-.710$ & .651 & (21.7) & & $1.9-3.0$ & 2.5 & (16.5) & & $6.6-12.2$ & 9.0 & (21.3) & & $63.0-75.0$ & 69.3 & (23.5) & \\
\hline GUSA & 3 & $.140-.419$ & .282 & (9.4) & & $.6-2.2$ & 1.5 & (10.1) & & $.3-2.2$ & 1.3 & $(3.0)$ & & $17.0-60.0$ & 45.7 & $(15.5)$ & \\
\hline CELA & 3 & $0.000-.197$ & .183 & (6.1) & 83.9 & $0.4-1.2$ & 1.0 & ( 6.8) & 85.7 & $0.3-.5$ & .6 & (1.2) & 92.1 & $14.3-25.0$ & 18.3 & (9.6) & 73.5 \\
\hline MUTO & 3 & $.001-.247$ & .091 & ( 3.0$)$ & & $.0-1.4$ & .6 & (3.7) & & $0.0-3.0$ & 1.0 & (2.4) & & $0.0-20.0$ & 6.7 & (2.3) & \\
\hline STNE & 1 & & .056 & ( 1.9$)$ & & & .3 & $(2.0)$ & & & .5 & (1.1) & & & 6.7 & (2.3) & \\
\hline SPAI & 3 & $.015-.084$ & .056 & $(1.9\}$ & & $.2-1.3$ & .6 & ( 4.2) & & $0.0-.3$ & .2 & $(.4)$ & & $0.0-7.0$ & 4.0 & ( 1.4$)$ & \\
\hline ORHY & 2 & $0.000-.100$ & .052 & ( 1.7$)$ & & $0.0-.1$ & .0 & ( . .3) & & $0.0-1.0$ & .4 & ( .9$)$ & & $0.0-25.0$ & 11.7 & $(4.0)$ & \\
\hline SIHY & 2 & $0.000-.081$ & .047 & $(1.6)$ & & $0.0-.1$ & .0 & $(.2)$ & & $0.0-.5$ & .3 & $(.7)$ & & $0.0-25.0$ & 12.7 & (4.3) & \\
\hline SPCR & 3 & $.021-.056$ & .042 & $(1.4)$ & & $.0-\quad .1$ & .1 & ( . .5) & & $.1-.3$ & .2 & ( . .5) & & $3.0-15.0$ & 9.3 & (3.2) & \\
\hline STIP & 1 & & .029 & ( 1.0$)$ & & & .2 & ( 1.0$)$ & & & .2 & $($ ( .6) & & & 5.0 & ( 1.7$)$ & \\
\hline LEER & 1 & & .020 & $(.7)$ & & & .0 & $(0.0)$ & & & .2 & $(.5)$ & & & 5.0 & $(1.7)$ & \\
\hline JUMO & 1 & & .012 & $(.4)$ & & & .2 & ( 1.1$)$ & & & 0.0 & $(0.0)$ & & & 0.0 & $(0.0)$ & \\
\hline OPCL & 1 & & .009 & ( . .3) & & & .1 & (. .4) & & & .0 & $(.1)$ & & & 1.7 & $(.6)$ & \\
\hline CRYP & 1 & & .008 & 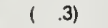 & & & .0 & $(.1)$ & & & .1 & $(\quad .2)$ & & & 1.7 & $\left(\begin{array}{l}(.6) \\
(1)\end{array}\right.$ & \\
\hline TETR & 1 & & .007 & ( . .2) & & & .0 & $(.1)$ & & & .0 & ( 1.1$)$ & & & 1.7 & ( . .6) & \\
\hline SPHA & 1 & & .007 & ( . .2) & & & 0.0 & $(0.0)$ & & & .1 & (. .1) & & & 1.7 & ( . .6) & \\
\hline HAGR1 & 1 & & .005 & $\left(\begin{array}{l}(2) \\
\text { ( })\end{array}\right.$ & & & 0.0 & $(0.0)$ & & & .0 & $(0.0)$ & & & 1.0 & $(.3)$ & \\
\hline COVI & 1 & & .005 & ( . .2) & & & 0.0 & $(0.0)$ & & & .0 & $(0.0)$ & & & 1.0 & ( . .3) & \\
\hline ATCA & 1 & & .005 & $(.2)$ & & & .1 & (. .4) & & & 0.0 & $(0.0)$ & & & 0.0 & $(0.0)$ & \\
\hline TAPA 1 & 1 & & .005 & ( 2) & & & 0.0 & $(0.0)$ & & & .0 & $(0.0)$ & & & 1.7 & $\left(\begin{array}{l}1 \\
(.6)\end{array}\right.$ & \\
\hline SPDI & 1 & & .005 & ( . .2) & & & 0.0 & $(0.0)$ & & & .0 & $(0.0)$ & & & 1.7 & ( . .6) & \\
\hline EPVI & 1 & & .005 & $\left(\begin{array}{l}(.2) \\
(1)\end{array}\right.$ & & & 0.0 & $(0.0)$ & & & .0 & $(0.0)$ & & & 1.7 & $\left(\begin{array}{l}(.6) \\
(.)\end{array}\right.$ & \\
\hline ARNO & 1 & & .005 & $\left(\begin{array}{l}(.2) \\
\text { ( }\end{array}\right.$ & & & 0.0 & $(0.0)$ & & & .0 & $(0.0)$ & & & 1.7 & $\left(\begin{array}{l}(\text { ( .6) }\end{array}\right.$ & \\
\hline ERIO1 & 1 & & .003 & ( . .1) & & & 0.0 & $(0.0)$ & & & .0 & $(0.0)$ & & & 1.0 & ( $\quad .3)$ & \\
\hline ARTR & 1 & & .003 & ( $\quad .1)$ & & & 0.0 & $(0.0)$ & & & .0 & $(0.0)$ & & & 1.0 & $\left(\begin{array}{ll}( & .3\end{array}\right)$ & \\
\hline SCPA & 1 & & .002 & $(.1)$ & & & .0 & ( . .2) & & & 0.0 & $(0.0)$ & & & 0.0 & $(0.0)$ & \\
\hline ARFE1 & 1 & & .002 & (.1) & & & .0 & ( . .2) & & & 0.0 & $(0.0)$ & & & 0.0 & $(0.0)$ & \\
\hline & & & 3.000 & & & & 14.9 & & & & 42.0 & & & & & & \\
\hline
\end{tabular}

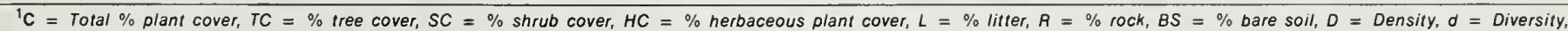
$S R_{2}=$ Species richness.

3 plant species symbol (see Appendix B for full nomenclature).

${ }^{4} \mathrm{~K}=$ Constancy.

${ }^{4} K=$ Constancy.
${ }_{T P}=$ Total percent for species with $I V \geqslant 0.1$.

Table 30. - Vegetation and soil surface characteristics for plant community 25 (p.c.25).

COMMUNITY 25 : Atcu-Frja/Spal

SITES $\quad 88$

Mean'

$\begin{array}{lllllllllllll}\text { No. Sites } & \text { No. Trans. } & \frac{C}{2} & \frac{T C}{15.5} & \frac{\text { SC }}{10.4} & \frac{H C}{5.1} & \frac{L}{0} & \frac{R}{4.9} & \frac{B^{2}}{90.0} & \frac{D}{7.8} & \frac{d}{1.78} & \frac{\text { SR }}{13}\end{array}$

\section{IMPORTANCE VALUE}

PERCENT COVER

DENSITY

PERCENT FREQUENCY

\begin{tabular}{|c|c|c|c|c|c|c|c|c|c|c|c|c|c|c|c|c|c|}
\hline SPECIES $^{3}$ & $k^{4}$ & RANGE & MEAN & $\%$ TOTAL & $T P^{5}$ & RANGE & MEAN & $\%$ TOTAL & $T P^{5}$ & RANGE & MEAN & $\%$ TOTAL & $T P^{5}$ & RANGE & MEAN & $\%$ TOTAL & $T P^{5}$ \\
\hline SPAI & 1 & & 1.033 & (34.4) & & & 3.3 & (21.3) & & & 3.8 & (48.7) & & & 90.0 & (33.3) & \\
\hline ATCU & 1 & & .510 & $(17.0)$ & & & 4.4 & $(28.4)$ & & & .9 & $(11.5)$ & & & 30.0 & (11.1) & \\
\hline FRJA & 1 & & .416 & (13.9) & & & 4.9 & (31.6) & & & .2 & ( 2.6$)$ & & & 20.0 & (7.4) & \\
\hline CELA & 1 & & 225 & ( 7.5) & & & .2 & $(1.3)$ & & & .5 & $(6.4)$ & & & 40.0 & (14.8) & \\
\hline HIJA & 1 & & .202 & $(6.7)$ & & & .4 & $(2.6)$ & & & .8 & $(10.3)$ & & & 20.0 & $(7.4)$ & \\
\hline UNKF & 1 & & .140 & (4.7) & & & .4 & (2.6) & & & 6 & $(7.7)$ & & & 10.0 & (3.7) & \\
\hline SPCO & 1 & & .114 & ( 3.8) & & & .8 & $(5.2)$ & & & .2 & ( 2.6) & & & 10.0 & ( 3.7$)$ & \\
\hline YUGL & 1 & & .108 & ( 3.6$)$ & 91.6 & & .9 & $(5.8)$ & 98.8 & & .1 & (1.3) & 91.1 & & 10.0 & $(3.7)$ & 85.2 \\
\hline OPCL & 1 & & .075 & ( 2.5$)$ & & & 0.0 & $(0.0)$ & & & 3 & $(3.8)$ & & & 10.0 & $(3.7)$ & \\
\hline ASTR & 1 & & .063 & ( 2.1) & & & 0.0 & $(0.0)$ & & & .2 & $(2.6)$ & & & 10.0 & (3.7) & \\
\hline Susu & 1 & & .050 & $(1.7)$ & & & 0.0 & $(0.0)$ & & & .1 & $(1.3)$ & & & 10.0 & (3.7) & \\
\hline BOGR & 1 & & .050 & ( 1.7$)$ & & & 0.0 & $(0.0)$ & & & .1 & ( 1.3$)$ & & & 10.0 & (3.7) & \\
\hline ECHI1 & 1 & & .013 & $(.4)$ & & & .2 & (1.3) & & & 0.0 & $(0.0)$ & & & 0.0 & $(0.0)$ & \\
\hline & & & 2.999 & & & & 15.5 & & & & 7.8 & & & & & & \\
\hline
\end{tabular}

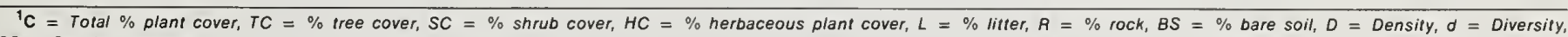
$S R_{2}=$ Species richness.

${ }_{3}$ Plant species symbol (see Appendix B for full nomenclature).

${ }^{4} \mathrm{~K}=$ Constancy.

${ }^{5} T P=$ Total percent for species with $I V \geqslant 0.1$. 
Table 31. - Vegetation and soil surface characteristics for plant community 26 (p.c.26)

COMMUNITY 26 : Atob/Spai-Spcr

SITES $\quad 65 \quad 68$

Mean

$\begin{array}{lllllllllllll}\text { No. Sites } & \text { No. Trans. } & \frac{C}{4} & \frac{\mathrm{TC}}{19.9} & \frac{\mathrm{SC}}{15} & \frac{\mathrm{HC}}{4.8} & \frac{\mathrm{L}}{5.2} & \frac{\mathrm{R}}{0} & \frac{\text { BS }^{2}}{90.0} & \frac{\mathrm{D}}{12.1} & \frac{\mathrm{d}}{0.24} & \frac{\mathrm{SR}}{8}\end{array}$

DENSITY

PERCENT FREQUENCY

\begin{tabular}{|c|c|c|c|c|c|c|c|c|c|c|c|c|c|c|c|c|c|}
\hline SPECIES $^{3}$ & $k^{4}$ & RANGE & MEAN & $\%$ TOTAL & $T P^{5}$ & RANGE & MEAN & $\%$ TOTAL & $T P^{5}$ & RANGE & MEAN & $\%$ TOTAL & $T P^{5}$ & RANGE & MEAN & $\%$ TOTAL & $T P^{5}$ \\
\hline ATOB & 2 & $.523-3.000$ & 1.762 & $(58.7)$ & & $6.0-22.3$ & 14.2 & (71.2) & & $.3-9.2$ & 4.7 & (39.1) & & $20.0-100.0$ & 60.0 & (53.6) & \\
\hline SPAI & 1 & & 1.001 & $(33.4)$ & & & 4.4 & (22.2) & & & 6.6 & (54.2) & & & 38.5 & $(34.4)$ & \\
\hline SPCR & 1 & & .120 & $(4.0)$ & 96.1 & & .1 & (. .3) & 93.7 & & .7 & (6.1) & 99.4 & & 8.5 & $(7.6)$ & 95.6 \\
\hline OPIM & 1 & & .052 & $(1.7)$ & & & .9 & ( 4.5) & & & 0.0 & $(0.0)$ & & & 0.0 & $(0.0)$ & \\
\hline SIHY & 1 & & .046 & ( 1.5$)$ & & & 0.0 & $(0.0)$ & & & .1 & ( $\quad .7)$ & & & 5.0 & ( 4.5$)$ & \\
\hline HIJA & 1 & & .016 & ( $\quad .5)$ & & & .3 & $(1.4)$ & & & 0.0 & $(0.0)$ & & & 0.0 & $(0.0)$ & \\
\hline BOGR & 1 & & .003 & (. .1) & & & .1 & (. .3) & & & 0.0 & $(0.0)$ & & & 0.0 & $(0.0)$ & \\
\hline OPPO & 1 & & .001 & $(0.0)$ & & & .0 & (.1) & & & 0.0 & $(0.0)$ & & & 0.0 & $(0.0)$ & \\
\hline & & & 3.000 & & & & 19.9 & & & & 12.1 & & & & & & \\
\hline
\end{tabular}

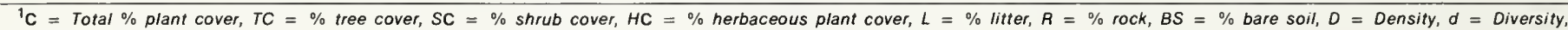
$S R=$ Species richness

${ }^{2} B S=100-(H C+L+R)$

${ }^{3}$ Plant species symbol (see Appendix B for full nomenclature)

${ }^{4} \mathrm{~K}=$ Constancy.

${ }^{5} T P=$ Total percent for species with $N \geqslant 0.1$

Table 32. - Vegetation and soil surface characteristics for plant community 27 (p.c.27)

Mean ${ }^{1}$

COMMUNITY 27 : Alob-Gusa/Hija.Spal

SITES $\quad 46 \quad 47$

$\begin{array}{lllllllllllll}\text { No. Sites } & \text { No. Trans. } & \frac{C}{6} & \frac{T C}{9.3} & \frac{S C}{3.0} & \frac{H C}{6.3} & \frac{L}{2.7} & \frac{R}{0.1} & \frac{B^{2}}{90.9} & \frac{D}{14.4} & \frac{d}{1.10} & \frac{S R}{14}\end{array}$

\begin{tabular}{|c|c|c|c|c|c|c|c|c|c|c|c|c|c|c|c|c|c|}
\hline \multirow[b]{2}{*}{ SPECIES $^{3}$} & \multirow[b]{2}{*}{$k^{4}$} & \multicolumn{4}{|c|}{ IMPORTANCE VALUE } & \multicolumn{4}{|c|}{ PERCENT COVER } & \multicolumn{4}{|c|}{ DENSITY } & \multicolumn{4}{|c|}{ PERCENT FREQUENCY } \\
\hline & & RANGE & MEAN & $\%$ TOTAL & $T P^{5}$ & RANGE & MEAN & $\%$ TOTAL & $T P^{5}$ & RANGE & MEAN & $\%$ TOTAL & $T P^{5}$ & RANGE & MEAN & $\%$ TOTAL & $T P^{5}$ \\
\hline HIJA & 2 & $1.274-1.309$ & 1.292 & $(43.1)$ & & $2.3-4.2$ & 3.3 & (34.9) & & $7.4-11.1$ & 9.3 & $(64.5)$ & & $50.0-53.0$ & 51.5 & $(30.7)$ & \\
\hline SPAI & 2 & $.537-.811$ & .674 & $(22.5)$ & & $2.5-3.3$ & 2.9 & $(30.8)$ & & $1.4-3.7$ & 2.5 & (17.5) & & $20.0-37.0$ & 28.5 & (17.0) & \\
\hline ATOB & 2 & $.397-.472$ & .435 & $(14.5)$ & & $1.5-2.2$ & 1.8 & (19.6) & & $.7-.8$ & .8 & $(5.2)$ & & $23.0-40.0$ & 31.5 & (18.8) & \\
\hline GUSA & 2 & $.278-.405$ & .342 & $(11.4)$ & & $.6-1.4$ & 1.0 & $(10.4)$ & & $.6-\quad .9$ & .7 & ( 5.0$)$ & & $30.0-33.0$ & 31.5 & $(18.8)$ & \\
\hline SPCR & 2 & $.027-.199$ & .113 & $(3.8)$ & 95.3 & $.0-.1$ & .1 & ( .9) & 96.6 & $.0-1.4$ & .7 & (5.1) & 97.3 & $3.0-17.0$ & 10.0 & $(6.0)$ & 91.3 \\
\hline CELA & 1 & & .030 & $(1.0)$ & & & .1 & $(.5)$ & & & .1 & $(.5)$ & & & 3.5 & ( 2.1$)$ & \\
\hline SCPA & 1 & & .027 & ( .9) & & & 0.0 & $(0.0)$ & & & .1 & ( . .5) & & & 3.5 & ( 2.1) & \\
\hline UNKF & 1 & & .022 & ( . .7) & & & 0.0 & $(0.0)$ & & & .2 & ( 1.4) & & & 1.5 & $(.9)$ & \\
\hline ASTR & 1 & & .021 & $(.7)$ & & & 0.0 & $(0.0)$ & & & .0 & $(.2)$ & & & 3.5 & (2.1) & \\
\hline MUTO & 1 & & .012 & (. .4) & & & .1 & ( . .9) & & & 0.0 & $(0.0)$ & & & 0.0 & $(0.0)$ & \\
\hline SPHA & 1 & & .010 & ( . .3) & & & .1 & ( 1.2$)$ & & & 0.0 & $(0.0)$ & & & 0.0 & $(0.0)$ & \\
\hline SIHY & 1 & & .010 & ( . .3) & & & 0.0 & $(0.0)$ & & & .0 & (.1) & & & 1.5 & ( .9) & \\
\hline OPIM & 1 & & .009 & ( . .3) & & & 0.0 & $(0.0)$ & & & 0.0 & $(0.0)$ & & & 1.5 & ( .9) & \\
\hline OPPO & 1 & & .006 & ( .2) & & & .1 & ( .7) & & & 0.0 & $(0.0)$ & & & 0.0 & $(0.0)$ & \\
\hline & & & $\overline{3.000}$ & & & & 9.3 & & & & 14.4 & & & & & & \\
\hline
\end{tabular}

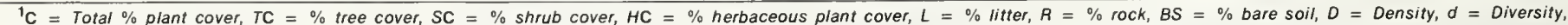
$S R=$ Species richness

3 Plant species symbol $($ see Appendix B for full nomenclature).

$4 \mathrm{~K}$ (ant species sym

${ }^{5} T P=$ Total percent for species with $I V \geqslant 0.1$ 
Table 33. - Vegetation and soil surface characteristics for plant community 28 (p.c.28).

Mean $^{1}$

COMMUNITY 28 : Atca/Hija

SITES $\quad 132$ $\begin{array}{lllllllllllll}\text { No. Sltes } & \text { No. Trans. } & \frac{C}{1} & \frac{C}{14.8} & \frac{T C}{0} & \frac{S C}{11.6} & \frac{H C}{3.2} & \frac{L}{13.4} & \frac{R}{0.1} & \frac{B^{2}}{83.3} & \frac{D}{7.1} & \frac{d}{1.48} & \frac{S R}{10}\end{array}$

\begin{tabular}{|c|c|c|c|c|c|c|c|c|c|c|c|c|c|c|c|c|c|}
\hline \multirow[b]{2}{*}{ SPECIES $^{3}$} & \multirow[b]{2}{*}{$k^{4}$} & \multicolumn{3}{|c|}{ IMPORTANCE VALUE } & \multicolumn{5}{|c|}{ PERCENT COVER } & \multicolumn{4}{|c|}{ DENSITY } & \multicolumn{4}{|c|}{ PERCENT FREOUENCY } \\
\hline & & RANGE & MEAN & $\%$ TOTAL & $\mathrm{TP}^{5}$ & RANGE & MEAN & $\%$ TOTAL & $T P^{5}$ & RANGE & MEAN & $\%$ TOTAL & $T P^{5}$ & RANGE & MEAN & $\%$ TOTAL & $T P^{5}$ \\
\hline ATCA & 1 & & .707 & $(23.6)$ & & & 10.5 & $(70.7)$ & & & 0.0 & $(0.0)$ & & & 0.0 & $(0.0)$ & \\
\hline HIJA & 1 & & .669 & (22.3) & & & 1.0 & (6.6) & & & 3.1 & (43.7) & & & 20.0 & (16.7) & \\
\hline SPCO & 1 & & .378 & (12.6) & & & .0 & $(.2)$ & & & .9 & (12.7) & & & 30.0 & $(25.0)$ & \\
\hline DIST & 1 & & .371 & (12.4) & & & .1 & $(.7)$ & & & 1.4 & (19.7) & & & 20.0 & $(16.7)$ & \\
\hline SPNE1 & 1 & & .349 & (11.6) & & & .4 & ( 2.7$)$ & & & 1.1 & (15.5) & & & 20.0 & (16.7) & \\
\hline GUSA & 1 & & .308 & (10.3) & & & 1.1 & ( 7.1) & & & .5 & $(7.0)$ & & & 20.0 & (16.7) & \\
\hline ARFE1 & 1 & & .118 & ( 3.9$)$ & 96.7 & & .3 & ( 2.0) & 90.0 & & .1 & $(1.4)$ & 100 & & 10.0 & (8.3) & 100 \\
\hline SPAI & 1 & & .063 & (2.1) & & & .9 & $(6.3)$ & & & 0.0 & $(0.0)$ & & & 0.0 & $(0.0)$ & \\
\hline BOGR & 1 & & .036 & $(1.2)$ & & & .5 & ( 3.6$)$ & & & 0.0 & $(0.0)$ & & & 0.0 & $(0.0)$ & \\
\hline SIHY & 1 & & .002 & ( .1) & & & .0 & ( . .2) & & & 0.0 & $(0.0)$ & & & 0.0 & $(0.0)$ & \\
\hline & & & 3.001 & & & & 14.8 & & & & 7.1 & & & & & & \\
\hline
\end{tabular}

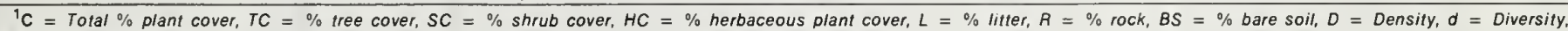
$S R=$ Species richness

3 Plant species symbol (see Appendix B for full nomenclature).

${ }^{4} \mathrm{~K}=\mathrm{Con}$ species symb

${ }^{5} \mathrm{~K}=$ Constancy.

Table 34.-Vegetation and soil surface characteristics for plant community 29 (p.c.29)

COMMUNITY 29 : Atca/Spal.SIhy

$\begin{array}{lllll}\text { SITES } & 59 & 70 & 107 & 139\end{array}$

Mean

\begin{tabular}{|c|c|c|c|c|c|c|c|c|c|c|c|c|c|c|c|c|c|}
\hline \multirow[b]{2}{*}{ SPECIES $^{3}$} & \multirow[b]{2}{*}{$k^{4}$} & \multicolumn{4}{|c|}{ IMPORTANCE VALUE } & \multicolumn{4}{|c|}{ PERCENT COVER } & \multicolumn{4}{|c|}{ DENSITY } & \multicolumn{4}{|c|}{ PERCENT FREQUENCY } \\
\hline & & RANGE & MEAN & $\%$ TOTAL & $T P^{5}$ & RANGE & MEAN & $\%$ TOTAL & $T P^{5}$ & RANGE & MEAN & $\%$ TOTAL & $T P^{5}$ & RANGE & MEAN & $\%$ TOTAL & $T P^{5}$ \\
\hline SPAI & 4 & $.339-1.342$ & .947 & $(31.6)$ & & $2.8-6.2$ & 4.2 & (23.3) & & $.3-8.3$ & 4.5 & $(50.6)$ & & $7.0-55.0$ & 34.8 & (27.3) & \\
\hline ATCA & 4 & $.339-1.162$ & .780 & $(26.0)$ & & $3.1-21.2$ & 9.9 & $(54.6)$ & & $.1-1.1$ & 6 & $(6.7)$ & & $10.0-55.0$ & 26.5 & (20.8) & \\
\hline SIHY & 3 & $0.000-.473$ & .234 & ( 7.8$)$ & & $0.0-1.7$ & .5 & ( 3.0$)$ & & $0.0-2.3$ & .9 & ( 9.9$)$ & & $0.0-15.0$ & 9.8 & ( 7.6$)$ & \\
\hline GUSA & 4 & $.098-.199$ & .147 & ( 4.9) & & $.3-.8$ & .6 & ( 3.1$)$ & & $.1-.8$ & .3 & ( 2.9$)$ & & $5.0-15.0$ & 9.8 & $(7.6)$ & \\
\hline SPCR & 4 & $.004-.356$ & .123 & (4.1) & & $0.0-\quad .2$ & .1 & ( . .5) & & $0.0-1.2$ & .5 & ( 5.7$)$ & & $0.0-30.0$ & 10.5 & ( 8.2$)$ & \\
\hline SPCO & 2 & $0.000-.481$ & .121 & $(4.0)$ & 78.4 & $0.0-.7$ & .2 & $(1.0)$ & 85.5 & $0.0-2.3$ & 6 & (6.3) & 82.1 & $0.0-25.0$ & 6.3 & ( 4.9) & 76.4 \\
\hline ATCO & 2 & $0.000-.330$ & .097 & ( 3.2$)$ & & $0.0-1.7$ & .5 & (2.6) & & $0.0-.2$ & .1 & $(.7)$ & & $0.0-13.0$ & 4.0 & (3.1) & \\
\hline HIJA & 1 & & .090 & ( 3.0$)$ & & & .4 & ( 2.0) & & & .4 & ( 4.2) & & & 2.5 & ( 2.0) & \\
\hline SPIN & 2 & $0.000-.262$ & .076 & ( 2.5$)$ & & $0.0-.1$ & .0 & $(.2)$ & & $0.0-.5$ & .1 & ( 1.6$)$ & & $0.0-7.0$ & 2.5 & $(2.0)$ & \\
\hline ATOB & 2 & $0.000-.155$ & .065 & $(2.2)$ & & $0.0-.8$ & .4 & ( 2.1$)$ & & $0.0-.1$ & .0 & (.4) & & $0.0-7.0$ & 3.0 & $(2.4)$ & \\
\hline UNKF & 1 & & .056 & ( 1.9$)$ & & & .3 & ( 1.5$)$ & & & .3 & ( 2.8$)$ & & & 6.3 & ( 4.9) & \\
\hline SCPA & 1 & & .049 & ( 1.6$)$ & & & 0.0 & $(0.0)$ & & & .1 & ( 1.3$)$ & & & .8 & $(.6)$ & \\
\hline PORT & 1 & & .044 & ( 1.5$)$ & & & .0 & (.1) & & & .1 & ( . .8) & & & 1.8 & (1.4) & \\
\hline SAVE2 & 1 & & .037 & ( 1.2$)$ & & & .6 & ( 3.4$)$ & & & 0.0 & $(0.0)$ & & & 0.0 & $(0.0)$ & \\
\hline PAOB & 1 & & .025 & $(.8)$ & & & .1 & $(.6)$ & & & .3 & $(2.8)$ & & & 1.3 & $(1.0)$ & \\
\hline BOGR & 1 & & .022 & ( .7) & & & .1 & $(.6)$ & & & .0 & (.4) & & & 1.3 & $(1.0)$ & \\
\hline MURI1 & 1 & & .019 & ( . .6) & & & .0 & ( .1) & & & .2 & ( 2.1) & & & 1.3 & $(1.0)$ & \\
\hline MAVU & 1 & & .016 & ( .5) & & & .1 & ( .3) & & & 0 & ( .3) & & & 2.5 & $(2.0)$ & \\
\hline GRCA & 1 & & .013 & (. .4) & & & .0 & $(0.0)$ & & & .0 & $(.1)$ & & & .8 & ( . .6) & \\
\hline UKGRS & 1 & & .013 & ( .4) & & & 0.0 & $(0.0)$ & & & .0 & ( .1) & & & .8 & $(.6)$ & \\
\hline SPFL & 1 & & .013 & ( . 4) & & & 0.0 & $(0.0)$ & & & .0 & $(.4)$ & & & 1.3 & $(1.0)$ & \\
\hline $\mathrm{CHV} 12$ & 2 & $0.000-.020$ & .008 & ( .3) & & $0.0-.3$ & .1 & ( .7) & & $0.0-0.0$ & 0.0 & $(0.0)$ & & $0.0-0.0$ & 0.0 & $(0.0)$ & \\
\hline ARLO1 & 2 & $0.000-.013$ & .004 & ( .1) & & $0.0-\quad .0$ & .0 & $(0.0)$ & & $0.0-.0$ & 0 & $(0.0)$ & & $0.0-1.0$ & .3 & ( .2) & \\
\hline SEMU1 & 1 & & .002 & (.1) & & & .0 & ( .1) & & & 0.0 & $(0.0)$ & & & 0.0 & $(0.0)$ & \\
\hline SOLA & 1 & & .001 & $(0.0)$ & & & .0 & ( 1.1$)$ & & & 0.0 & $(0.0)$ & & & 0.0 & $(0.0)$ & \\
\hline ARTR & 1 & & .001 & $(0.0)$ & & & .0 & ( .1) & & & 0.0 & $(0.0)$ & & & 0.0 & $(0.0)$ & \\
\hline & & & 3.000 & & & & 18.1 & & & & 9.0 & & & & & & \\
\hline
\end{tabular}

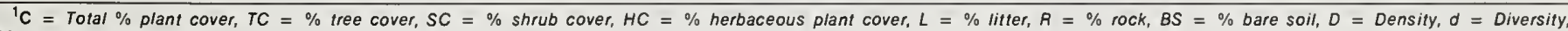
$S R=$ Species richness.

${ }^{2} B S=100-(H C+L+A)$

${ }^{3}$ Plant species symbol (see Appendix B for full nomenclature)

${ }^{4} K=$ Constancy.

${ }^{5} T P=$ Total percent for species with $I V \geqslant 0.1$ 
Table 35.-Vegetation and soil surface characteristics for plant community 30 (p.c.30)

COMMUNITY 30 : Atca.Gusa/Bogr.Spcr SITES

Mean'

\begin{tabular}{|c|c|c|c|c|c|c|c|c|c|c|c|c|c|c|c|c|c|}
\hline \multirow[b]{2}{*}{ SPECIES $^{3}$} & \multirow[b]{2}{*}{$k^{4}$} & \multicolumn{4}{|c|}{ IMPORTANCE VALUE } & \multicolumn{4}{|c|}{ PERCENT COVER } & \multicolumn{4}{|c|}{ DENSITY } & \multicolumn{4}{|c|}{ PERCENT FREQUENCY } \\
\hline & & RANGE & MEAN & $\%$ TOTAL & $T P^{5}$ & RANGE & MEAN & $\%$ TOTAL & $T P^{5}$ & RANGE & MEAN & $\%$ TOTAL & $T P^{5}$ & RANGE & MEAN & $\%$ TOTAL & $T P^{5}$ \\
\hline GUSA & 2 & $.441-.851$ & .646 & (21.5) & & $2.4-3.3$ & 2.9 & $(34.5)$ & & $.4-1.6$ & 1.0 & $(12.2)$ & & $30.0-47.0$ & 38.5 & $(16.3)$ & \\
\hline BOGR & 2 & $.443-.517$ & .480 & $(16.0)$ & & $.8-.9$ & .9 & $(10.5)$ & & $1.7-3.1$ & 2.4 & (28.7) & & $10.0-30.0$ & 20.0 & $\langle 8.5\rangle$ & \\
\hline SPCR & 2 & $.409-.463$ & .436 & $(14.5)$ & & $.3-.4$ & .4 & ( 4.2) & & $1.5-1.9$ & 1.7 & $(20.4)$ & & $40.0-50.0$ & 45.0 & (19.1) & \\
\hline SPCO & 2 & $.223-.375$ & 299 & $(10.0)$ & & $2-1.4$ & .8 & (9.5) & & $.5-.7$ & 6 & ( 7.2$)$ & & $33.0-33.0$ & 33.0 & $(14.0)$ & \\
\hline SPFL & 2 & $.221-.347$ & .284 & (9.5) & & $.1-1.1$ & 6 & $(7.1)$ & & $.7-8$ & .7 & $(8.8)$ & & $30.0-33.0$ & 31.5 & $(13.4)$ & \\
\hline ATCA & 2 & $.239-.272$ & .256 & $(8.5)$ & & $1.1-2.3$ & 1.7 & (20.6) & & $.1-.2$ & 1 & $(1.4)$ & & $7.0-13.0$ & 10.0 & $(4.2)$ & \\
\hline SPHA & 2 & $.021-.240$ & .131 & $(4.3)$ & & $0.0-.0$ & .0 & $(.2)$ & & $.1-.6$ & .3 & (3.8) & & $3.0-37.0$ & 20.0 & $(8.5)$ & \\
\hline UNKF & 2 & $.078-.163$ & .121 & $(4.0)$ & 88.3 & $.0-.1$ & 1 & ( . .6) & 87.2 & $.2-.6$ & .4 & (5.1) & 87.6 & $10.0-20.0$ & 15.0 & (6.4) & 90.4 \\
\hline HIJA & 2 & $.043-.124$ & .084 & (2.8) & & $0-1$ & 1 & $(8)$ & & $2-6$ & 4 & ( 4.8$)$ & & $3.0-10.0$ & 6.5 & 2.8 & \\
\hline SPAI & 2 & $.003-.125$ & .064 & (2.1) & & $.0-.3$ & .2 & (2.0) & & $0.0-5$ & .2 & (2.8) & & $0.0-7.0$ & 3.5 & ( 1.5$)$ & \\
\hline ARLO1 & 2 & $.010-.115$ & .063 & ( 2.1$)$ & & $.1-.4$ & .2 & (2.7) & & $0.0-5$ & .3 & (3.0) & & $0.0-3.0$ & 1.5 & ( . .6) & \\
\hline OPPO & 2 & $.015-.091$ & .053 & $(1.8)$ & & $1-5$ & 3 & (3.5) & & $0.0-1$ & .1 & (.6) & & $0.0-7.0$ & 3.5 & ( 1.5$)$ & \\
\hline ORHY & 1 & & .024 & $(.8)$ & & & .1 & $(1.6)$ & & & .0 & (. 2) & & & 1.5 & ( . .6) & \\
\hline OPIM & 2 & $.019-.025$ & .022 & $(.7)$ & & $0.0-.2$ & .1 & ( 1.0$)$ & & $0.0-.0$ & .0 & ( . 2) & & $0.0-3.0$ & 1.5 & ( . .6) & \\
\hline YUGL & 1 & & .011 & (. .3) & & & 0.0 & $(0.0)$ & & & .0 & (. 4) & & & 1.5 & $(.6)$ & \\
\hline HASP2 & 2 & $.003-.017$ & .010 & (. .3) & & $0.0-.0$ & .0 & ( . 2) & & $0.0-.0$ & .0 & (.2) & & $0.0-3.0$ & 1.5 & ( . .6) & \\
\hline ASTR & 1 & & .009 & (.3) & & & 0.0 & $(0.0)$ & & & .0 & (. 2) & & & 1.5 & ( .6) & \\
\hline $\mathrm{OPCL}$ & 1 & & .008 & ( . .2) & & & .1 & ( . .6) & & & 0.0 & $(0.0)$ & & & 0.0 & $(0.0)$ & \\
\hline MENT1 & 1 & & .005 & $(.2)$ & & & 0 & ( . . 4) & & & 0.0 & $(0.0)$ & & & 0.0 & $(0.0)$ & \\
\hline & & & $\overline{3.002}$ & & & & 8.3 & & & & 8.4 & & & & & & \\
\hline
\end{tabular}

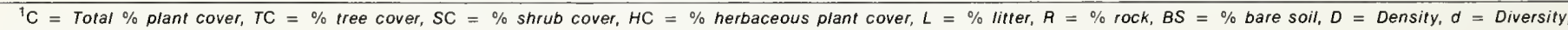
$S R=$ Species richness.

${ }^{2} B S=100-(H C+L+R)$.

${ }^{3}$ Plant species symbol (see Appendix B for full nomenclature).

${ }^{4} K=$ Constancy.

${ }^{5} \mathrm{TP}=$ Total percent for species with $\mathrm{N} \geqslant 0.1$

Table 36. - Vegetation and soil surface characteristics for plant community 31 (p.c.31)

Mean ${ }^{1}$

COMMUNITY 31 : Bogr-Hija

SITES $\quad 159 \quad 160$

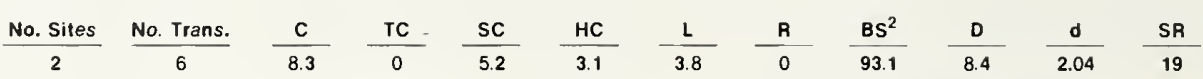

PERCENT FREQUENCY

.


Table 37.-Vegetation and soil surface characteristics for plant community 32 (p.c.32).

Mean $^{1}$

COMMUNITY 32 : Gusa/8ogr-HIja

$\begin{array}{lllllllll}\text { SITES } & 19 & 52 & 57 & 60 & 62 & 63 & 64 & 157\end{array}$ $\begin{array}{lllllllllllllll}\text { No. SItes } & \text { No. Trans. } & \frac{C}{21} & \frac{\text { TC }}{15.7} & \frac{S C}{0} & \frac{H C}{2.1} & \frac{\mathrm{H}}{13.6} & \frac{\mathrm{L}}{2.6} & \frac{\mathrm{R}}{0.1} & \frac{8 S^{2}}{83.7} & \frac{D}{75.8} & \frac{d}{0.95} & \frac{S R}{29}\end{array}$

DENSITY

PERCENT FREQUENCY

IMPORTANCE VALUE

PERCENT COVER

\begin{tabular}{|c|c|c|c|c|c|c|c|c|c|c|c|c|c|c|c|c|}
\hline $\mathrm{SPECIES}^{3}$ & $K^{4}$ & RANGE & MEAN & $\%$ TOTAL & $T P^{5}$ & RANGE & MEAN & $\%$ TOTAL & TP & RANGE & MEAN & $\%$ TOTAL & $T F$ & RANGE & MEAN & $\%$ TOTAL. \\
\hline
\end{tabular}

BOGR $\quad 8 \quad .947-1.876 \quad 1.474 \quad(49.1)$

$\begin{array}{lllrllll}\text { BOGR } & 8 & .947-1.876 & 1.474 & (49.1) & 3.9-14.6 & 8.3 & (52.9) \\ \text { HIJA } & 8 & .408-1.052 & .742 & (24.7) & 1.7-5.3 & 3.6 & (23.0) \\ \text { GUSA } & 8 & .101-.432 & .280 & (9.3) & .9-3.4 & 1.8 & (11.5)\end{array}$

$\begin{array}{llll}\text { HIJA } & 8 & .408-1.052 & .742 \\ \text { GUSA } & 8 & 101-.432 & 280\end{array}$

$\begin{array}{llllll}8 & .101-.432 & .280 & (9.3) & .2-3.4\end{array}$

\begin{tabular}{llllll}
\hline MUTO & 5 & $0.000-.287$ & .073 & $(2.4)$ &
\end{tabular}

$\begin{array}{lllll}\text { MUTO } & 5 & 0.000-.287 & .073 & (2.4)\end{array}$

$\begin{array}{lllll}\text { SIHY } & 5 & 0.000-.133 & .055 & (1.8) \\ \text { SPAI } & 6 & 0.000-.183 & .054 & (1.8)\end{array}$

ORHY $30.000-.224 \quad .047 \quad(1.6)$

$\begin{array}{lllll}\text { ARLO1 } & 5 & 0.000-.119 & .036 & (1.2)\end{array}$

$\begin{array}{lllll}\text { STNE } & 2 & 0.000-.118 & .021 & (.7)\end{array}$

$\begin{array}{lllll}\text { OPIM } & 3 & 0.000-.080 & .013 & (.4)\end{array}$

MUHL $220.000-.049 .012 \quad(.4)$

OPPO $30.000-.041 \quad .011 \quad(.4)$

$\begin{array}{lllllll}\text { CELA } & 3 & 0.000- & .033 & .007 & (.2)\end{array}$

$\begin{array}{lllll}C & \text { SCPA } & 1 & .006 & (.2)\end{array}$

$\begin{array}{llll}\text { AGSM } & 1 & .006 & (2)\end{array}$

$\begin{array}{llllll} & & & & .006 & (1 \\ \text { UNKF } & 2 & 0.000- & .033 & .006 & (.2)\end{array}$

ATCA

EULA

SPHA

LEER

EUFE

CHVI2

OPCL

CLEA

$\mathrm{U} 6012$

CRYP

ARTR

$\mathrm{SPCO} 2$

HASP

$$
\begin{array}{lll}
.004 & (.1) \\
0.004 &
\end{array}
$$

$0.000-.017 \quad .004 \quad\left(\begin{array}{lll}.1) \\ 004\end{array}\right.$

$.004 \quad(.1)$

$\begin{array}{ll}.003 & (.1) \\ .003 & (.1)\end{array}$

$\begin{array}{ll}.003 & \left(\begin{array}{l}1 \\ .003\end{array}\right) \\ .002 & (.1)\end{array}$

$.002 \quad\left(\begin{array}{ll}1 \\ \text {. }\end{array}\right.$

$.002 \quad(.1)$

.002 ( .1)

$.002 \quad(.1)$

$.002 \quad(0.0)$

$\begin{array}{ll}.001 & (0.0) \\ .001 & (0.0)\end{array}$

$001 \quad(0.0)$

$1.8 \quad(11.5)$

$0.0-1.9$

$0.0-1.6$
$0.0-.4$

$\begin{array}{ll}0.0- & .4 \\ 0.0- & .6\end{array}$

$0.0-.6$

$0.0-.5$

$\begin{array}{ll}0.0- & .5 \\ 0.0-\quad .5\end{array}$

$0.0-1.0$

$0.0-.2$

$0.0-.2$

$0.0-.1$

$0.0-0.0$

3.000

$\begin{array}{ccc}0.0-0.0 & 0.0 & (0.0) \\ 0.0 & (0.0)\end{array}$

$\begin{array}{rrr}1.8 & (11.5) & \\ .4 & (2.9) & 90.3 \\ .4 & (2.5) & \\ .1 & \left(\begin{array}{r}.7) \\ .3\end{array}\right. & \\ .1 & (1.9) & \end{array}$

$.3 \quad(1.9)$

$\left(\begin{array}{l}7 \\ (.6)\end{array}\right.$

$(.6)$

$\left(\begin{array}{r}.8) \\ (1.0)\end{array}\right.$

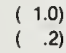

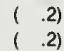

$\left(\begin{array}{ll} \\ ( & .1)\end{array}\right.$

$\left(\begin{array}{ll}.1) \\ (.1)\end{array}\right.$

$\left(\begin{array}{r}.1) \\ (0.0)\end{array}\right.$

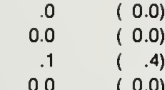

$(0.0)$
$(0.0)$

$\begin{array}{ll}0.0 & (0.0) \\ 0.0 & (0.0)\end{array}$

$\begin{array}{ll}0.0 & (0.0) \\ 0.0 & (0.0)\end{array}$

( .2)

$\left(\begin{array}{r}(1) \\ (0.0)\end{array}\right.$

$(0.0)$
$(\quad .2)$

$(\quad .2)$
$(\quad .2)$

$(0.0)$

$(0.0)$

$(0.0)$

15.7 $\begin{array}{llllll}9.8-99.3 & 54.0 & (71.2) & 47.0-95.0 & 77.3 & (25.4)\end{array}$

$\begin{array}{llllll}6.9-24.4 & 14.1 & (18.6) & 40.0-100.0 & 79.6 & (26.2)\end{array}$

$\begin{array}{lllll}1-3.0 & 1.6 & (2.1) & 10.0-70.0 & 44.4\end{array}$

$\begin{array}{llllllll}0.0-2.6 & 1.0 & (1.3) & 93.2 & 0.0-100.0 & 30.3 & (10.0) & 76.2\end{array}$

$\begin{array}{lllllll}0.0-9.7 & 2.4 & (3.1) & 0.0-40.0 & 9.9 & \text { ( 3.3) }\end{array}$

$\begin{array}{llllll}0.0-.7 & .3 & (.4) & 0.0-37.0 & 12.4 & (4.1)\end{array}$

$\begin{array}{llllll}0.0-2.2 & .4 & (.5) & 0.0-53.0 & 11.6 & (3.8)\end{array}$

$\begin{array}{lllll}0.0-1.7 & 5 & (.6) & 0.0-27.0 & 7.9\end{array}$

$0.0-1.7 \quad .5-(.6)$

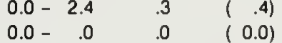

$\begin{array}{llll}0.0- & .1 & .0 & (0.0)\end{array}$

$\begin{array}{llll}0.0- & .1 & .0 & (0.0)\end{array}$

( . 2)

$\left(\begin{array}{r}.0) \\ (0.0)\end{array}\right.$

$\begin{array}{cccc}0.0-\quad .2 & .0 & (0.0) \\ & 0.0 & (0.0) \\ & & & \\ & & 0.0)\end{array}$

$(0.0)$
$(.1)$

$(0.0)$

( .1)

( 0.0$)$

$(0.0)$
$(0.0)$

$(0.0)$

$\left(\begin{array}{l}\text { (1) } \\ (0.0)\end{array}\right.$

( 0.0$)$

$(0.0)$
$(0.0)$

$(0.0)$

$(0.0)$

$0.0-27.0 \quad 7.9 \quad(2.6)$

$\begin{array}{rrrr}0.0-23.0 & 3.8 & (1.2) \\ 0.0- & 3.0 & .4 & (.1)\end{array}$

$\begin{array}{rrrr}0.0-3.0 & .4 & \left(\begin{array}{r}1 \\ 0.0-10.0\end{array} 2.5\right. & (.8)\end{array}$

$0.0-13.0 \quad 3.3 \quad(1.1)$

$\left.\begin{array}{ll}( & .4) \\ ( & .5\end{array}\right)$

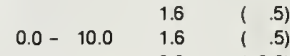

$\begin{array}{llll}0.0 & -5.0 & 1.3 & (.4)\end{array}$

(. .3)

(.3)

$(.3)$
$(0.0)$

$(0.0)$

( .1)

$(0.0)$

$(0.0)$
$(0.0)$

$\left(\begin{array}{ll}(1) \\ (\quad 1)\end{array}\right.$

$\left(\begin{array}{ll}1 \\ (1)\end{array}\right.$

75.8 $\begin{array}{llllll}0.0-2.9 & 6 & (.7) & 0.0-27.0 & 7.0 & (2.3)\end{array}$

$0.0-.8 \quad .2 \quad\left(\begin{array}{lll}(0.0) \\ 0.0\end{array}\right.$

$0.0-10.0 \quad 2.0 \quad(.7)$

$\begin{array}{rrr}0.0 & (0.0) \\ 0.0-5.3 & 1.3 & \left(\begin{array}{c}1 \\ -4\end{array}\right)\end{array}$

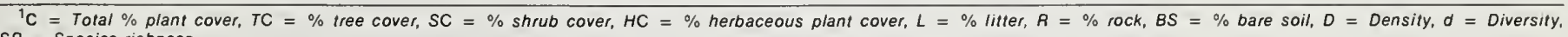
$S R=$ Species richness.
$2 B S=100-(H C+i$

Plant species symbol (see Appendix B for full nomenclature)

${ }_{5}^{4} K=$ Constancy.

${ }^{5} T P=$ Total percent for species with $I V \geqslant 0.1$.

Table 38.-Vegetation and soil surface characteristics for plant community 33 (p.c.33).

COMMUNITY 33 : Gusa/8ogr.Boer

SITES $\quad 69$

$\begin{array}{lllllllllllllll}1 & \frac{\mathrm{C}}{1} & \frac{\mathrm{HC}}{2} & \frac{\mathrm{TC}}{0} & \frac{\mathrm{SC}}{2.3} & \frac{\mathrm{HC}}{18.7} & \frac{\mathrm{L}}{0.3} & \frac{\mathrm{A}}{32.3} & \frac{8 S^{2}}{48.7} & \frac{\mathrm{D}}{46.7} & \frac{\mathrm{d}}{1.37} & \frac{\mathrm{SR}}{18}\end{array}$

IMPORTANCE VALUE

PERCENT COVER DENSITY

PERCENT FREQUENCY

\begin{tabular}{|c|c|c|c|c|c|c|c|c|c|c|c|c|c|c|c|c|c|}
\hline SPECIES $^{3}$ & $k^{4}$ & RANGE & MEAN & $\%$ TOTAL & $T P^{5}$ & RANGE & MEAN & $\%$ TOTAL & $T P^{5}$ & RANGE & MEAN & $\%$ TOTAL & $T P^{5}$ & RANGE & MEAN & $\%$ TOTAL & $T P^{5}$ \\
\hline BOGR & 1 & & 1.058 & (35.2) & & & 7.4 & $(35.0)$ & & & 23.9 & $(51.2)$ & & & 85.0 & (19.5) & \\
\hline BOER & 1 & & .662 & (22.1) & & & 5.3 & (25.2) & & & 9.5 & (20.3) & & & 90.0 & (20.7) & \\
\hline HIJA & 1 & & .607 & (20.2) & & & 4.4 & (20.7) & & & 8.5 & (18.1) & & & 95.0 & $(21.8)$ & \\
\hline GUSA & 1 & & .196 & (6.5) & & & 2.0 & (9.3) & & & .5 & (1.1) & & & 40.0 & $(9.2)$ & \\
\hline STNE & 1 & & .192 & (6.4) & 90.4 & & 1.1 & $(5.0)$ & 95.2 & & 2.9 & (6.1) & 96.8 & & 35.0 & (8.0) & 79.2 \\
\hline ZIGR & 1 & & .065 & ( 2.2) & & & .2 & $(.7)$ & & & .6 & $(1.2)$ & & & 20.0 & $(4.6)$ & \\
\hline ERLA & 1 & & .045 & ( 1.5$)$ & & & .1 & $\left(\begin{array}{ll}( & 5\end{array}\right)$ & & & .3 & $\left(\begin{array}{l}(.5) \\
(\end{array}\right.$ & & & 15.0 & (3.4) & \\
\hline SPCO & 1 & & .028 & ( . .9) & & & 0.0 & $(0.0)$ & & & .3 & ( . .5) & & & 10.0 & (2.3) & \\
\hline SIHY & 1 & & .025 & $(.8)$ & & & 0.0 & $(0.0)$ & & & .1 & $\left(\begin{array}{l}1 \\
(\quad 2)\end{array}\right.$ & & & 10.0 & ( 2.3) & \\
\hline OPIM & 1 & & .024 & $(.8)$ & & & .3 & $(1.2)$ & & & .1 & ( . 1) & & & 5.0 & ( 1.1$)$ & \\
\hline ARLO1 & 1 & & .024 & $(8)$ & & & .3 & ( 1.2$)$ & & & .1 & (. 1) & & & 5.0 & (1.1) & \\
\hline SPHA & 1 & & .015 & $(.5)$ & & & .1 & $\left(\begin{array}{l}(\quad .2\end{array}\right)$ & & & .1 & (. 1) & & & 5.0 & ( 1.1$)$ & \\
\hline MUHL & 1 & & .015 & $\left(\begin{array}{l}(.5) \\
(5)\end{array}\right.$ & & & .1 & $\left(\begin{array}{ll}( & .2\end{array}\right)$ & & & .1 & ( .1) & & & 5.0 & ( 1.1$)$ & \\
\hline VEBI & 1 & & .013 & (. .4) & & & 0.0 & $(0.0)$ & & & .1 & (.1) & & & 5.0 & (1.1) & \\
\hline SELO & : & & .013 & $(.4)$ & & & 0.0 & $(0.0)$ & & & .1 & ( . .1) & & & 5.0 & ( 1.1$)$ & \\
\hline LYPA 1 & 1 & & .013 & (. .4) & & & 0.0 & $(0.0)$ & & & .1 & (.1) & & & 5.0 & (1.1) & \\
\hline SCPA & 1 & & .005 & ( .2) & & & .1 & ( . .5) & & & 0.0 & $(0.0)$ & & & 0.0 & $(0.0)$ & \\
\hline SPCR & 1 & & .002 & $\left(\begin{array}{ll}( & .1\end{array}\right)$ & & & .1 & $\left(\begin{array}{l}(.2\end{array}\right)$ & & & 0.0 & $(0.0)$ & & & 0.0 & $(0.0)$ & \\
\hline
\end{tabular}

$\overline{3.002}$

21.0

46.7

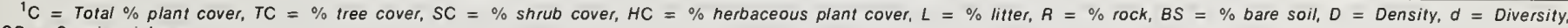

$S R=$ Species richness

$2 B S=100-(H C+L+R)$.
3 plant species symbol (see Appendix 8 for full nomenclature).

Plant species symt

${ }^{5} T P=$ Total percent for species with $I V \geqslant 0.1$. 
Table 39. - Vegetation and soil surface characteristics for plant community 34 (p.c.34)

Mean $^{1}$

COMMUNITY 34 : Bogr-Spai

SITES $\quad 131$ - Converted

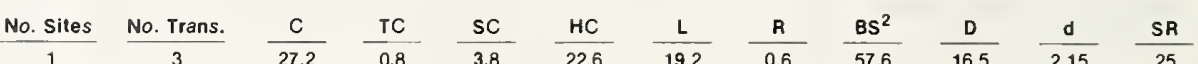
DENSITY

PERCENT FREQUENCY

\begin{tabular}{|c|c|c|c|c|c|c|c|c|c|c|c|c|c|c|c|c|c|}
\hline SPECIES $^{3}$ & $K^{4}$ & RANGE & MEAN & $\%$ TOTAL & $T P^{5}$ & RANGE & MEAN & $\%$ TOTAL & $T P^{5}$ & RANGE & MEAN & $\%$ TOTAL & $T P^{5}$ & RANGE & MEAN & $\%$ TOTAL & $T P^{5}$ \\
\hline BOGR & 1 & & .599 & $(20.0)$ & & & 6.2 & $(22.8)$ & & & 4.6 & (27.9) & & & 20.0 & $(9.2)$ & \\
\hline SPAI & 1 & & .411 & (13.7) & & & 6.4 & $\{23.4\}$ & & & .9 & ( $(5.5)$ & & & 27.0 & $(12.4)$ & \\
\hline AGDE & 1 & & .388 & (12.9) & & & 3.4 & $(12.4)$ & & & 2.1 & $(12.6)$ & & & 30.0 & $(13.8)$ & \\
\hline SPCR & 1 & & .343 & (11.4) & & & 2.6 & (9.6) & & & 2.0 & (12.3) & & & 27.0 & $(12.4)$ & \\
\hline AGIN & 1 & & .270 & (9.0) & & & .5 & $(1.7)$ & & & 2.6 & $(16.0)$ & & & 20.0 & $(9.2)$ & \\
\hline AGSM & 1 & & .193 & (6.4) & & & .3 & (1.1) & & & 1.7 & (10.5) & & & 17.0 & $(7.8)$ & \\
\hline SIHY & 1 & & .136 & $(4.5)$ & & & .4 & $(1.4)$ & & & .5 & $(3.0)$ & & & 20.0 & $(9.2)$ & \\
\hline OPIM & 1 & & .117 & ( 3.9$)$ & 81.8 & & 1.6 & $(6.0)$ & 79.2 & & .2 & $(1.0)$ & 88.8 & & 10.0 & $(4.6)$ & 78.6 \\
\hline AGTR2 & 1 & & .089 & $(3.0)$ & & & .5 & (1.9) & & & .9 & ( 5.5$)$ & & & 3.0 & $(1.4)$ & \\
\hline CRUC & 1 & & .062 & ( 2.1$)$ & & & 0.0 & $(0.0\}$ & & & .3 & $(1.6)$ & & & 10.0 & $(4.6)$ & \\
\hline HYAC & 1 & & .060 & $(2.0)$ & & & .6 & ( 2.1$)$ & & & .1 & $(.8)$ & & & 7.0 & ( 3.2$)$ & \\
\hline OPPO & 1 & & .044 & $(1.5)$ & & & .7 & $(2.7)$ & & & .0 & $(.2)$ & & & 3.0 & ( 1.4$)$ & \\
\hline SAVE2 & 1 & & .041 & $(1.4)$ & & & 1.1 & (4.1) & & & 0.0 & $(0.0)$ & & & 0.0 & $(0.0)$ & \\
\hline MESA & 1 & & .040 & ( 1.3$)$ & & & .6 & $(2.0)$ & & & .1 & $(.4)$ & & & 3.0 & $(1.4)$ & \\
\hline PENS & 1 & & .038 & ( 1.3$)$ & & & .0 & $(.1)$ & & & .1 & $(.6)$ & & & 7.0 & $(3.2)$ & \\
\hline LERE & 1 & & .037 & $(1.2)$ & & & .0 & $(0.0)$ & & & .1 & $(.6)$ & & & 7.0 & ( 3.2$)$ & \\
\hline ORHY & 1 & & .031 & $(1.0)$ & & & .3 & $(1.2)$ & & & .1 & $(.4)$ & & & 3.0 & $(1.4)$ & \\
\hline SCPA & 1 & & .028 & $(.9)$ & & & .1 & $\left(\begin{array}{l}(.2\end{array}\right)$ & & & .2 & $(1.0)$ & & & 3.0 & $(1.4)$ & \\
\hline PIED & 1 & & .019 & $(.6)$ & & & .5 & $(1.9)$ & & & 0.0 & $(0.0)$ & & & 0.0 & $(0.0)$ & \\
\hline HIJA & 1 & & .016 & ( . .5) & & & .4 & $(1.6)$ & & & 0.0 & $(0.0)$ & & & 0.0 & $(0.0)$ & \\
\hline POFE & 1 & & .012 & $(.4)$ & & & .3 & $(1.2)$ & & & 0.0 & $(0.0)$ & & & 0.0 & $(0.0)$ & \\
\hline JUMO & 1 & & .012 & $\left(\begin{array}{l}(4) \\
(.5)\end{array}\right.$ & & & .3 & $(1.2)$ & & & 0.0 & $(0.0)$ & & & 0.0 & $(0.0)$ & \\
\hline CEMO & 1 & & .006 & $\left(\begin{array}{l}\text { ( .2) } \\
\text { (n) }\end{array}\right.$ & & & 2 & $(.6)$ & & & 0.0 & $(0.0)$ & & & 0.0 & $(0.0)$ & \\
\hline ARLU & 1 & & .006 & $\left(\begin{array}{l}(.2) \\
(.0)\end{array}\right.$ & & & .2 & $\left(\begin{array}{l}(.6\end{array}\right)$ & & & 0.0 & $(0.0)$ & & & 0.0 & $(0.0)$ & \\
\hline HYRI & 1 & & .001 & $(0.0)$ & & & .0 & $(.1)$ & & & 0.0 & $(0.0)$ & & & 0.0 & $(0.0)$ & \\
\hline & & & 2.999 & & & & 27.2 & & & & 16.5 & & & & & & \\
\hline
\end{tabular}

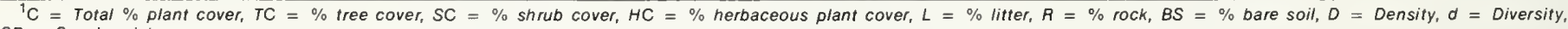
$S R=$ Species richness .

${ }^{2} B S=100-(H C+L+R)$.

${ }^{3}$ Plant species symbol (see Appendix $B$ for full nomenclature).

${ }_{5}^{4} K=$ Constancy.

${ }^{5} \mathrm{TP}=$ Total percent for species with $\mathrm{IV} \geqslant 0.1$.

Table 40.-Vegetation and soil surface characteristics for plant community 35 (p.c.35).

Mean $^{1}$

COMMUNITY 35 : Gusa/Boer.Hija

SITES $\quad 44 \quad 105$ $\begin{array}{llllllllllllll}\text { No. Sites } & \text { No. Trans. } & \frac{C}{6} & \frac{\text { TC }}{14.6} & \frac{S C}{0} & \frac{H C}{2.3} & \frac{H C}{12.3} & \frac{L}{4.5} & \frac{R}{12.5} & \frac{\text { S }^{2}}{70.7} & \frac{D}{29.4} & \frac{d}{1.63} & \frac{S R}{23}\end{array}$ DENSITY

PERCENT FREOUENCY

\begin{tabular}{|c|c|c|c|c|c|c|c|c|c|c|c|c|c|c|c|c|c|}
\hline SPECIES $^{3}$ & $K^{4}$ & RANGE & MEAN & $\%$ TOTAL & $T P^{5}$ & RANGE & MEAN & $\%$ TOTAL & $T P^{5}$ & RANGE & MEAN & $\%$ TOTAL & $T P^{5}$ & RANGE & MEAN & $\%$ TOTAL & $T P^{5}$ \\
\hline HIJA & 2 & $.722-.742$ & .732 & $(24.4)$ & & $1.3-5.1$ & 3.2 & $(22.0)$ & & $5.6-14.8$ & 10.2 & $(34.7)$ & & $47.0-53.0$ & 50.0 & $(17.7)$ & \\
\hline BOER & 2 & $.386-.438$ & .412 & (27.5) & & $.8-2.7$ & 1.8 & $(24.4)$ & & $3.4-6.2$ & 4.8 & $(32.6)$ & & $26.5-40.0$ & 33.3 & $(23.6)$ & \\
\hline SPAI & 1 & & .273 & (9.1) & & & .7 & ( 4.6$)$ & & & 1.8 & ( 6.2$)$ & & & 15.0 & ( 5.3$)$ & \\
\hline GUSA & 2 & $.056-.332$ & .194 & ( 6.5$)$ & & $.1-2.9$ & 1.5 & $(10.4)$ & & $.1-1.4$ & .8 & ( 2.6$)$ & & $7.0-60.0$ & 33.5 & (11.9) & \\
\hline STNE & 1 & & .138 & $(4.6)$ & & & .9 & $(5.9)$ & & & 2.1 & $(7.2)$ & & & 16.5 & ( 5.9$)$ & \\
\hline SPCA & 2 & $.113-.143$ & .128 & ( 4.3$)$ & & $.2-.8$ & .5 & (3.3) & & $.4-\quad .9$ & .6 & $(2.2)$ & & $20.0-20.0$ & 20.0 & $(7.1)$ & \\
\hline BOGR & 1 & & .121 & $(4.0)$ & & & 1.5 & (10.5) & & & 1.4 & $(4.7)$ & & & 6.5 & ( 2.3) & \\
\hline ATCA & 2 & $.013-.195$ & .104 & ( 3.5$)$ & & $.3-1.2$ & .7 & (5.1) & & $0.0-\quad .0$ & .0 & $(.1)$ & & $0.0-3.0$ & 1.5 & ( . .5) & \\
\hline UNKF & 1 & & .102 & (3.4) & 87.3 & & .1 & ( .6) & 86.8 & & .6 & (2.1) & 92.4 & & 11.5 & ( 4.1) & 78.4 \\
\hline ARLO1 & 2 & $.057-.129$ & .093 & ( 3.1$)$ & & $.2-.7$ & .5 & ( 3.1$)$ & & $.2-1.7$ & 1.0 & $(3.2)$ & & $3.0-20.0$ & 11.5 & $(4.1)$ & \\
\hline MUPO1 & 1 & & .064 & ( 2.1) & & & .9 & (6.1) & & & .4 & ( 1.4$)$ & & & 5.0 & $(1.8)$ & \\
\hline SPCO & 2 & $.043-.060$ & .052 & $(1.7)$ & & $.1-.2$ & .1 & ( .9) & & $.0-.4$ & .2 & $(.7)$ & & $3.0-17.0$ & 10.0 & ( 3.5$)$ & \\
\hline SIHY & 1 & & .030 & $(1.0)$ & & & .1 & ( . .3) & & & .2 & ( . .5) & & & 8.5 & $(3.0)$ & \\
\hline ASIT & 1 & & .026 & ( . .9) & & & .1 & $(.6)$ & & & .1 & $(.4)$ & & & 6.5 & ( 2.3$)$ & \\
\hline ASTR & 2 & $.023-.026$ & .025 & $(.8)$ & & $0.0-.1$ & .1 & $(.4)$ & & $.1-\quad .1$ & .1 & 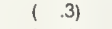 & & $3.0-7.0$ & 5.0 & ( 1.8$)$ & \\
\hline HASP2 & 1 & & .022 & $(.7)$ & & & .1 & $(.6)$ & & & .0 & ( . .1) & & & 1.5 & $\left(\begin{array}{ll}( & .5\end{array}\right)$ & \\
\hline TRPU & 1 & & .021 & $(.7)$ & & & .0 & (. .1) & & & .1 & $(.2)$ & & & 3.5 & $(1.2)$ & \\
\hline LEER & 1 & & .018 & ( . .6) & & & .1 & ( . .3) & & & .2 & ( .8$)$ & & & 3.5 & $(1.2)$ & \\
\hline SOLA & 1 & & .009 & ( . .3) & & & 0.0 & $(0.0)$ & & & .0 & ( . .1) & & & 1.5 & $(.5)$ & \\
\hline SENE & 1 & & .009 & $(.3)$ & & & 0.0 & $(0.0)$ & & & .0 & $(.1)$ & & & 1.5 & $(.5)$ & \\
\hline SPNE1 & 1 & & .008 & ( . .3) & & & .1 & ( . .3) & & & 0.0 & $(0.0)$ & & & 0.0 & $(0.0)$ & \\
\hline LYPA1 & 1 & & .006 & $(2)$ & & & .0 & ( . .1) & & & .0 & ( . .1) & & & 1.5 & ( . .5) & \\
\hline ARTE & 1 & & .006 & $(.2)$ & & & .0 & $(.1)$ & & & .0 & ( . .1) & & & 1.5 & $(.5)$ & \\
\hline CHNA & 1 & & .001 & $(0.0)$ & & & .0 & ( .1) & & & 0.0 & $(0.0)$ & & & 0.0 & $(0.0)$ & \\
\hline & & & 3.000 & & & & 14.6 & & & & 29.4 & & & & & & \\
\hline
\end{tabular}

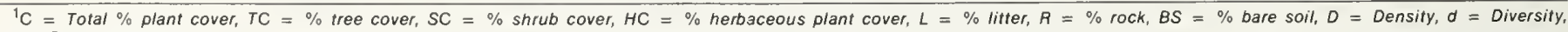
$S R=$ Species richness.

3 Plant species symbol (see Appendix B for full nomenclature).

${ }_{5}^{4} \mathrm{~K}=$ Constancy.

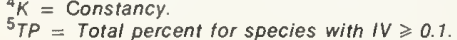


Table 41.-Vegetation and soil surface characteristics for plant community 36 (p.c.36).

COMMUNITY 36 : Gusa/Hija-Bogr

$\begin{array}{lllllll}\text { SITES } & 27 & 32 & 61 & 84 & 137 & 148\end{array}$

Mean ${ }^{1}$

IMPORTANCE VALUE

$\begin{array}{lllllllllllll}\text { No. SIles } & \text { No. Trans. } & \frac{C}{16} & \frac{T C}{13.8} & \frac{S C}{3.4} & \frac{H C}{10.4} & \frac{L}{5.7} & \frac{R}{4.7} & \frac{B^{2}}{79.2} & \frac{D}{33.4} & \frac{d}{1.25} & \frac{S R}{35}\end{array}$ PERCENT COVER

DENSITY

PERCENT FREQUENCY

\begin{tabular}{|c|c|c|c|c|c|c|c|c|c|c|c|c|c|c|c|c|c|}
\hline SPECIES $^{3}$ & $k^{4}$ & RANGE & MEAN & $\%$ TOTAL & $T P^{5}$ & RANGE & MEAN & $\%$ TOTAL & $T P^{5}$ & RANGE & MEAN & $\%$ TOTAL & $T P^{5}$ & RANGE & MEAN & $\%$ TOTAL & $T P^{5}$ \\
\hline HIJA & 6 & $.922-1.650$ & 1.205 & $(40.2)$ & & $1.8-8.2$ & 5.0 & (36.3) & & $6.6-31.3$ & 15.6 & (46.9) & & $65.0-100.0$ & 83.0 & (32.9) & \\
\hline BOGA & 6 & $.137-.838$ & .658 & (22.0) & & $.6-4.9$ & 2.9 & (21.2) & & $.9-28.5$ & 10.8 & (32.3) & & $10.0-55.0$ & 39.7 & (15.7) & \\
\hline GUSA & 6 & $.103-1.098$ & .402 & (13.4) & & $.3-7.8$ & 2.5 & (18.0) & & $.1-5.9$ & 2.3 & $(6.8)$ & & $10.0-70.0$ & 40.5 & (16.1) & \\
\hline MUTO & 4 & $0.000-.392$ & .124 & (4.1) & & $0.0-2.9$ & .8 & ( 5.9$)$ & & $0.0-5.7$ & 1.3 & $(4.0)$ & & $0.0-30.0$ & 10.3 & (4.1) & \\
\hline SPAI & 5 & $0.000-.253$ & .104 & ( 3.5$)$ & 83.2 & $0.0-2.0$ & .6 & ( 4.7$)$ & 86.1 & $0.0-2.5$ & .7 & (2.2) & 92.2 & $0.0-18.0$ & 7.0 & ( 2.8) & 71.6 \\
\hline SPCR & 3 & $0.000-.215$ & .072 & (2.4) & & $0.0-.3$ & .1 & $(.6)$ & & $0.0-3.2$ & .8 & (2.4) & & $0.0-53.0$ & 14.3 & $(5.7)$ & \\
\hline ARLO 1 & 2 & $0.000-.384$ & .066 & (2.2) & & $0.0-1.4$ & .2 & $(1.7)$ & & $0.0-3.7$ & 6 & ( 1.9$)$ & & $0.0-50.0$ & 8.8 & (3.5) & \\
\hline ATCA & 4 & $0.000-.126$ & .053 & ( 1.8$)$ & & $0.0-1.1$ & .5 & ( 3.4$)$ & & $0.0-.2$ & .0 & (.1) & & $0.0-13.0$ & 3.3 & ( 1.3$)$ & \\
\hline SIHY & 4 & $0.000-.117$ & .042 & ( 1.4) & & $0.0-.5$ & .1 & $(.5)$ & & $0.0-.9$ & .2 & (.7) & & $0.0-18.0$ & 8.5 & (3.4) & \\
\hline ORHY & 4 & $0.000-.176$ & .036 & $(1.2)$ & & $0.0-1.0$ & .2 & ( 1.2$)$ & & $0.0-1.0$ & .2 & ( .6) & & $0.0-25.0$ & 5.7 & ( 2.2) & \\
\hline STNE & 1 & & .024 & ( .8) & & & .0 & ( .1) & & & .1 & (. 4) & & & 2.2 & & \\
\hline$A R B \mid 2$ & 1 & & .020 & (.7) & & & .0 & ( .2) & & & .0 & $(.1)$ & & & 2.2 & ( . .9) & \\
\hline EPHE & 1 & & .020 & $(.7)$ & & & .1 & $(.6)$ & & & .0 & $(0.0)$ & & & .5 & $(.2)$ & \\
\hline ATCO & 2 & $0.000-.097$ & .020 & ( .7) & & $0.0-1.1$ & .2 & ( 1.7$)$ & & $0.0-.1$ & .0 & $(0.0)$ & & $0.0-8.0$ & 1.3 & ( . .5) & \\
\hline LEER & 2 & $0.000-.064$ & .019 & $(.6)$ & & $0.0-0.0$ & 0.0 & $(0.0)$ & & $0.0-.3$ & .1 & ( . .2) & & $0.0-13.0$ & 3.8 & (1.5) & \\
\hline EULA & 3 & $0.000-.063$ & .019 & $($ ( .6) & & $0.0-.3$ & .1 & $(.6)$ & & $0.0-.6$ & .1 & $(.4)$ & & $0.0-17.0$ & 3.8 & (1.5) & \\
\hline AGSM & 2 & $0.000-.067$ & .016 & ( . .5) & & $0.0-.2$ & .1 & ( .5$)$ & & $0.0-.2$ & .1 & (.1) & & $0.0-17.0$ & 3.3 & (1.3) & \\
\hline EULA1 & 1 & & .013 & $(.4)$ & & & 0.0 & $(0.0)$ & & & .0 & ( .1) & & & 2.2 & $(.9)$ & \\
\hline STCO 1 & 1 & & .009 & $(.3)$ & & & .0 & ( . .3) & & & .1 & $($ (.2) & & & 1.3 & $(.5)$ & \\
\hline FRJA & 1 & & .008 & (. .3) & & & .0 & ( . .2) & & & .0 & $(0.0)$ & & & .5 & ( . .2) & \\
\hline OPPO & 1 & & .008 & (. .3) & & & .0 & ( . .3) & & & .0 & $(0.0)$ & & & .8 & $(.3)$ & \\
\hline OPCL & 1 & & .007 & $(.2)$ & & & .0 & $(0.0)$ & & & .1 & $(.1)$ & & & 2.2 & $(.9)$ & \\
\hline BOCU & 1 & & .007 & ( .2) & & & 0.0 & $(0.0)$ & & & .1 & ( . .2) & & & .5 & ( . .2) & \\
\hline GRIN & 1 & & .005 & ( . .2) & & & .0 & (.1) & & & .0 & $(0.0)$ & & & .8 & $(.3)$ & \\
\hline ERIO1 & 1 & & .005 & ( . 2) & & & 0.0 & $(0.0)$ & & & .0 & $(0.0)$ & & & .8 & ( .3) & \\
\hline CHNA & 1 & & .005 & ( . .2) & & & .0 & ( . .3) & & & .0 & $(0.0)$ & & & .5 & ( . .2) & \\
\hline TAPA1 & 1 & & .005 & (. .2) & & & 0.0 & $(0.0)$ & & & .0 & $(0.0)$ & & & .8 & (. .3) & \\
\hline SPHA & 1 & & .005 & $(.2)$ & & & 0.0 & $(0.0)$ & & & .0 & $(0.0)$ & & & .8 & ( . .3) & \\
\hline CELA & 1 & & .005 & ( . .2) & & & .1 & ( . .6) & & & 0.0 & $(0.0)$ & & & 0.0 & $(0.0)$ & \\
\hline OPUN & 1 & & .004 & $(.1)$ & & & .0 & $\left(\begin{array}{ll}( & .2\end{array}\right)$ & & & .0 & $(0.0)$ & & & .5 & $\left(\begin{array}{l}(\quad 2) \\
\text { ( }\end{array}\right.$ & \\
\hline MUSO & 1 & & .003 & (.1) & & & .0 & (. 1) & & & .0 & $(.1)$ & & & .5 & (. .2) & \\
\hline ARTR & 1 & & .002 & (. .1) & & & .0 & ( . .2) & & & 0.0 & $(0.0)$ & & & 0.0 & $(0.0)$ & \\
\hline UFORB & 1 & & .002 & ( .1) & & & 0.0 & $(0.0)$ & & & .0 & $(0.0)$ & & & .5 & ( .2) & \\
\hline EUFE & 1 & & .002 & (.1) & & & 0.0 & $(0.0)$ & & & .0 & $(0.0)$ & & & .5 & ( . .2) & \\
\hline DAFO & 1 & & .002 & (.1) & & & 0.0 & $(0.0)$ & & & .0 & $(0.0)$ & & & .5 & (. .2) & \\
\hline YUAN & 1 & & .001 & $(0.0)$ & & & .0 & (.1) & & & 0.0 & $(0.0)$ & & & 0.0 & $(0.0)$ & \\
\hline JUMO & 1 & & .001 & $(0.0)$ & & & .0 & ( .1) & & & 0.0 & $(0.0)$ & & & 0.0 & $(0.0)$ & \\
\hline & & & $\overline{2.998}$ & & & & $\overline{13.8}$ & & & & 33.4 & & & & & & \\
\hline
\end{tabular}

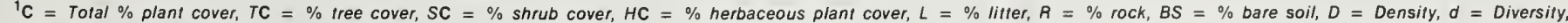
$S R=$ Species richness.

3 Plant species symbol (see Appendix $B$ for full nomenclature).

${ }^{4} \mathrm{~K}=$ Constancy.

${ }^{5} T P=$ Total percent for species with $I V \geqslant 0.1$ 
Table 42.-Vegetation and soil surface characteristics for plant community 37 (p.c.37).

Mean $^{1}$

COMMUNITY 37 : Hija.Spai

$\begin{array}{lllllll}\text { SITES } & 24 & 31 & 43 & 45 & 93\end{array}$

$\begin{array}{lllllllllllll}\text { No. Sites } & \text { No. Trans. } & \frac{C}{17} & \frac{T C}{13.5} & \frac{\mathrm{SC}}{0} & \frac{\mathrm{HC}}{0.2} & \frac{\mathrm{L}}{13.3} & \frac{\mathrm{L}}{3.3} & \frac{\mathbf{R}}{0.1} & \frac{\mathbf{B S}^{2}}{83.3} & \frac{\mathrm{D}}{66.3} & \frac{\mathrm{d}}{1.03} & \frac{\mathrm{SR}}{21}\end{array}$

IMPORTANCE VALUE

PERCENT COVER DENSITY

PERCENT FREQUENCY

\begin{tabular}{|c|c|c|c|c|c|c|c|c|c|c|c|c|c|c|c|c|c|}
\hline SPECIES 3 & $K^{4}$ & RANGE & MEAN & $\%$ TOTAL & $T P^{5}$ & RANGE & MEAN & $\%$ TOTAL & $T P^{5}$ & RANGE & MEAN & $\%$ TOTAL & $T P^{5}$ & RANGE & MEAN & $\%$ TOTAL & $T P^{5}$ \\
\hline
\end{tabular}

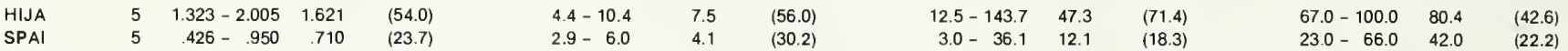

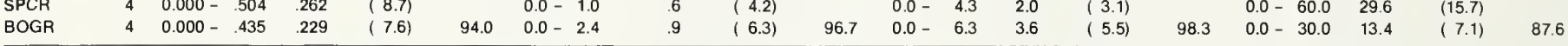

\begin{tabular}{llll}
\hline ORHY & 1 & $033 \quad(1,1)$
\end{tabular}

$\begin{array}{llllll}\text { ORHY } & 1 & & .033 & (1.1) & \\ \text { GUSA } & 3 & 0.000-.058 & .031 & (1.0) & 0.0-.3 \\ \text { ARLO1 } & 2 & 0.000-.078 & 024 & (8) & 0.0-\end{array}$

MUTO

EUPH

CELA

ARTR

SCPA

SAKA

SIHY

ATOB

ASTR

ATCO

OPIM

ATCA

$.024 \quad(.8)$

$\begin{array}{ll}.014 & \left(\begin{array}{l}5 \\ .014\end{array}\right) \\ .012 & (.5)\end{array}$

$\begin{array}{ll}.014 & \left(\begin{array}{l}5 \\ 012\end{array}\right)(.4) \\ .011 & (.4)\end{array}$

$0.000-.031 \quad .012 \quad\left(\begin{array}{lll}.4 \\ .411\end{array}\right)$

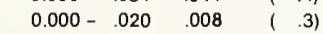

$\begin{array}{ll}.007 & (.2) \\ .005 & (.2)\end{array}$

$\begin{array}{ll}.005 & (.2) \\ .004 & (.1)\end{array}$

$\begin{array}{ll}.004 & \left(\begin{array}{l}1 \\ .004\end{array}\right) \\ .003 & (.1)\end{array}$

$.003(.1)$

$.002 \quad(.1)$

$.002 \quad(.1)$

$\begin{array}{ll}.002 & (.1) \\ .002 & (.1)\end{array}$

$\overline{3.000}$

$0.0-\quad .2$

\begin{tabular}{|c|c|}
\hline .1 & $\left(\begin{array}{l}(5) \\
(5)\end{array}\right.$ \\
\hline .1 & $\left(\begin{array}{l}(\quad 8) \\
0\end{array}\right.$ \\
\hline .0 & ( . .3) \\
\hline .0 & ( . .1) \\
\hline .0 & $(0.0)$ \\
\hline .1 & $(.4)$ \\
\hline .0 & ( $\quad .3)$ \\
\hline 0.0 & $(0.0)$ \\
\hline .0 & $(0.0)$ \\
\hline .0 & ( . .1) \\
\hline 0.0 & $(0.0)$ \\
\hline 0.0 & $(0.0)$ \\
\hline 0.0 & $(0.0)$ \\
\hline 0.0 & $(0.0)$ \\
\hline .0 & ( . .2) \\
\hline .0 & ( . .3) \\
\hline .0 & ( . .1) \\
\hline
\end{tabular}

$\begin{array}{lll}0.0- & 1 & .1\end{array}$

$\left(\begin{array}{ll} \\ (.1)\end{array}\right.$

(.2)

$(.7)$

$(.1)$

$\left(\begin{array}{r}0.0) \\ (\quad 2)\end{array}\right.$

$\left(\begin{array}{r}2) \\ (.1)\end{array}\right.$

$\left(\begin{array}{r}.1 \\ (0.0)\end{array}\right.$

$\left(\begin{array}{l}0.0) \\ (0.0)\end{array}\right.$

$(0.0)$
$(.1)$

$(0.0)$

$(0.0)$

$(0.0\rangle$

$(0.0)$

$(0.0)$
$(0.0)$

$5.0 \quad(2.6)$

$0.0-8.0 \quad 4.6 \quad(2.4)$

$0.0-13.0 \quad 3.2 \quad(1.7)$

$\left(\begin{array}{r}(1.7) \\ (3)\end{array}\right.$

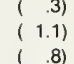

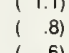

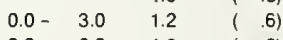

$0.0-3.0 \quad 1.2 \quad\left(\begin{array}{lll}.6 \\ 0\end{array}\right.$

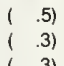

$\left.\begin{array}{ll}( & 3 \\ ( & 3\end{array}\right)$

( .3)

( . .3)

$(3)$

$\left(\begin{array}{ll}3 \\ (0.0)\end{array}\right.$

0.0

$(0.0)$

66.3 $S R=$ Species richness.

$B S=100-(H C+L+R)$.

${ }_{4}^{3}$ Plant species symbol (see Appendix B for full nomenclature)

${ }_{5}^{4} K=$ Constancy.

${ }^{5} T P=$ Total percent for species with $I V \geqslant 0.1$.

Table 43.-Vegetation and soil surface characteristics for plant community 38 (p.c.38)

COMMUNITY 38 : Gusa/HIja.Spc

SITES $\quad 58$

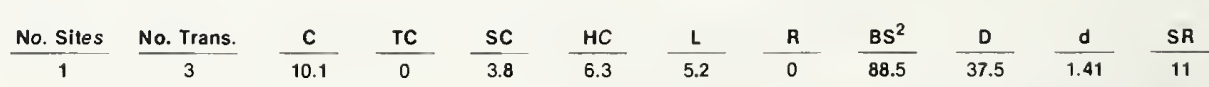

IMPORTANCE VALUE

PERCENT COVER

DENSITY

PERCENT FREOUENCY

\begin{tabular}{|c|c|c|c|c|c|c|c|c|c|c|c|c|c|c|c|c|c|}
\hline SPECIES 3 & $K^{4}$ & RANGE & MEAN & $\%$ TOTAL & $T P^{5}$ & RANGE & MEAN & $\%$ TOTAL & $T P^{5}$ & RANGE & MEAN & $\%$ TOTAL & $T P^{5}$ & RANGE & MEAN & $\%$ TOTAL & $T P^{5}$ \\
\hline HIJA & 1 & & 1.079 & $(36.0)$ & & & 2.9 & (28.7) & & & 18.6 & (49.6) & & & 87.0 & (29.8) & \\
\hline GUSA & 1 & & .685 & $(22.8)$ & & & 3.7 & (36.7) & & & 3.0 & $(8.0)$ & & & 70.0 & $\langle 24.0\rangle$ & \\
\hline SPCR & 1 & & .565 & (18.8) & & & .9 & (9.2) & & & 7.5 & $(20.0)$ & & & 80.0 & $(27.4)$ & \\
\hline BOGR & 1 & & .405 & (13.5) & & & 1.8 & (17.8) & & & 6.0 & (15.9) & & & 20.0 & ( 6.8$)$ & \\
\hline SPAI & 1 & & .103 & $(3.4)$ & 94.5 & & .5 & ( 5.3$)$ & 97.7 & & 1.5 & ( 3.9$)$ & 97.4 & & 3.0 & $(1.0)$ & 89.0 \\
\hline ORHY & 1 & & .064 & (2.1) & & & .0 & $\left(\begin{array}{l}(3) \\
(3)\end{array}\right.$ & & & .6 & $(1.5)$ & & & 13.0 & ( 4.5$)$ & \\
\hline AGSM & 1 & & .049 & $(1.6)$ & & & .1 & ( . .7) & & & .3 & $\left(\begin{array}{l}(.8\end{array}\right)$ & & & 10.0 & $(3.4)$ & \\
\hline ATCA & 1 & & .012 & ( 4$)$ & & & 0.0 & $(0.0)$ & & & .0 & (. .1) & & & 3.0 & $(1.0)$ & \\
\hline ARLO1 & 1 & & .012 & 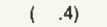 & & & 0.0 & $(0.0)$ & & & .0 & $(.1)$ & & & 3.0 & $(1.0)$ & \\
\hline ARLO & 1 & & .012 & $(.4)$ & & & 0.0 & $(0.0)$ & & & .0 & $(.1)$ & & & 3.0 & $(1.0)$ & \\
\hline OPPO & 1 & & .010 & ( . .3) & & & .1 & $(1.0)$ & & & 0.0 & $(0.0)$ & & & 0.0 & $(0.0)$ & \\
\hline LEER & 1 & & .003 & $(.1)$ & & & .0 & 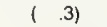 & & & 0.0 & $(0.0)$ & & & 0.0 & $(0.0)$ & \\
\hline & & & 2.999 & & & & 10.1 & & & & 37.5 & & & & & & \\
\hline
\end{tabular}

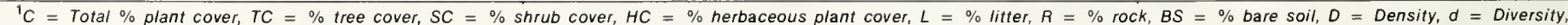
$S R=$ Species richness

3 Plant species symbol (see Appendix B for full nomenclature)

${ }^{4} \mathrm{~K}=$ Constancy.

${ }^{5} \mathrm{TP}=$ Constancy. 
Table 44.-Vegetation and soil surface characteristics for plant community 39 (p.c.39).

COMMUNITY 39 : SpaI

SITES $\quad 54$

Mean ${ }^{1}$

IMPORTANCE VALUE

$\begin{array}{lllllllllllll}\text { No. Sites } & \text { No. Trans. } & \frac{C}{5} & \frac{\text { TC }}{15.1} & \frac{\text { SC }}{0} & \frac{H C}{14.8} & \frac{L}{2.2} & \frac{R}{0} & \frac{\text { BS }^{2}}{83.0} & \frac{D}{57.5} & \frac{d}{0.19} & \frac{\text { SR }}{7}\end{array}$

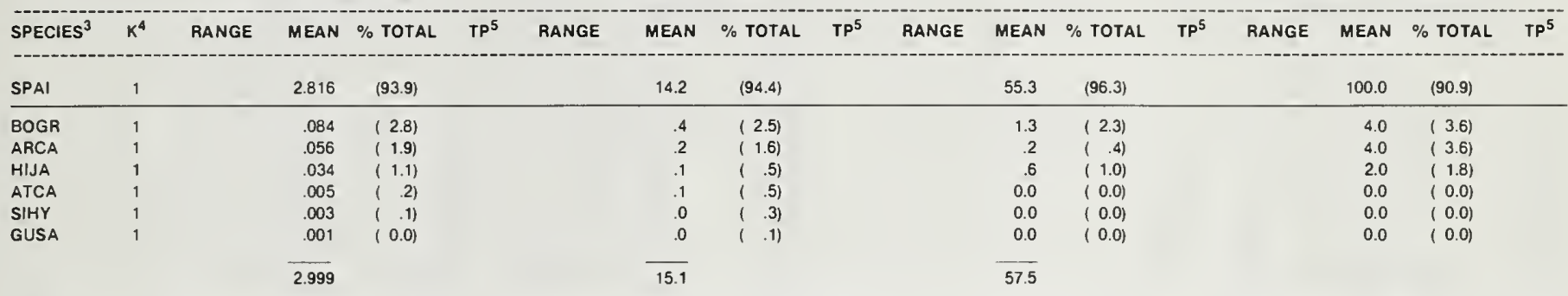

PERCENT COVER

DENSITY

PERCENT FREQUENCY

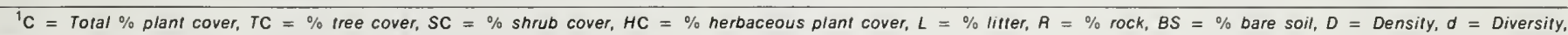
$S R=$ Species richness.

${ }_{3} B S=100-(H C+L+R)$.
${ }_{3}$ Plani species symbol (see Appendix B for full nomenclature).

${ }^{4} \mathrm{~K}=$ Cont species sym
Constancy

${ }^{4} \mathrm{~K}=$ Constancy.
${ }_{\mathrm{TP}}=$ Tolal percent lor species with $I V \geqslant 0.1$

Table 45.-Vegetation and soil surface characteristics for plant community 40 (p.c.40).

Mean $^{1}$

COMMUNITY 40 : Spai-Bogr

$\begin{array}{llllll}\text { SITES } & 53 & 86 & 149 & 154 & 155\end{array}$

$\begin{array}{lllllllllllllll}\text { No. Sites } & \text { No. Trans. } & \frac{C}{7} & \frac{\text { TC }}{24.7} & \frac{\text { SC }}{1.7} & \frac{H C}{23.0} & \frac{L}{5.1} & \frac{R}{0} & \frac{\text { BS }^{2}}{71.9} & \frac{D}{26.5} & \frac{d}{1.07} & \frac{\text { SR }}{23}\end{array}$
PERCENT COVER DENSITY

PERCENT FREQUENCY

IMPORTANCE VALUE

\begin{tabular}{|c|c|c|c|c|c|c|c|c|c|c|c|c|c|c|c|c|c|}
\hline SPECIES ${ }^{3}$ & $k^{4}$ & RANGE & MEAN & $\%$ TOTAL & $T P^{5}$ & RANGE & MEAN & $\%$ TOTAL & $T P^{5}$ & RANGE & MEAN & $\%$ TOTAL & $T P^{5}$ & RANGE & MEAN & $\%$ TOTAL & $T P^{5}$ \\
\hline
\end{tabular}

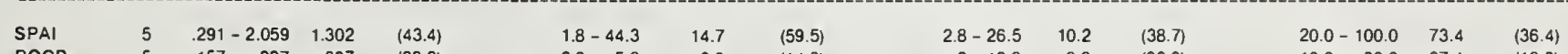

\begin{tabular}{|c|c|c|c|c|c|c|c|c|c|c|c|c|}
\hline PAI & 5 & $.291-2.059$ & 1.302 & (43.4) & $1.8-44.3$ & 14.7 & (59.5) & $2.8-26.5$ & 10.2 & (38.7) & $20.0-100.0$ & (36.4) \\
\hline OGR & 5 & $.157-.997$ & .697 & (23.2) & $2.3-5.8$ & 3.6 & $(14.6)$ & $.3-12.8$ & 8.8 & (33.3) & $10.0-60.0$ & (18.6) \\
\hline
\end{tabular}

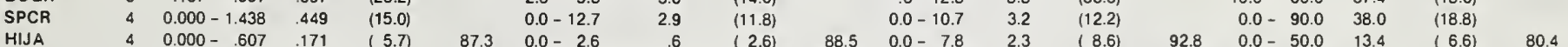

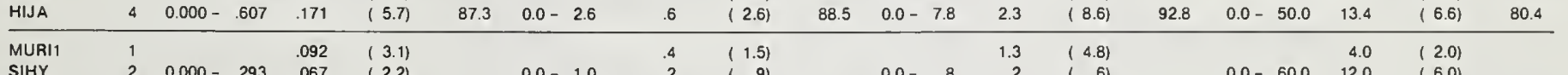

SIHY

OPIM $\begin{array}{llll}0.000-.293 & .067 & (2.2)\end{array}$

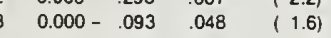
$20.000-.121 \quad .030 \quad(1.0)$

$0.0-1.0$

$0.0-\quad .8$

OPPO

LYPA

SAVE2

ATCA

$\begin{array}{llll}1 & 0.000-.061 & .018 & \left(\begin{array}{l}1 \\ .616\end{array}\right) \\ ( & .5)\end{array}$

$\begin{array}{llll}0.000-.046 & .015 & \left(\begin{array}{l}.5 \\ 1\end{array}\right) \\ & .013 & (.4)\end{array}$

$0.0-1.5$

$0.0-1.4$

SAKA

SAKA

EPTO

EPTO

SPHA

HASP

SPCO

SCPA

CLSE

SPOR

BACC

ARBI2

$0.0-\quad .4$

$(.4)$
$(.4)$

$(.4)$

$.012 \quad(.4)$

$\begin{array}{ll}.011 & (.4) \\ .010 & (.3)\end{array}$

$\begin{array}{ll}.010 & \left(\begin{array}{l}(.3) \\ .010\end{array}(.3)\right.\end{array}$

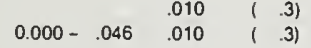

$\begin{array}{lll}.010 & ( & .3) \\ .006 & (.2)\end{array}$

$.004 \quad\left(\begin{array}{ll}1 \\ \text {. }\end{array}\right)$

$.004 \quad(.1)$

$\begin{array}{ll}.004 & (. .1) \\ 0.01\end{array}$

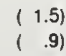

$(.9)$
$(\quad .6)$

( 1.8 )

$(1.8)$
$(.7)$

$(.7)$
$(1.4)$

$\left(\begin{array}{ll}1 \\ 1 & .7)\end{array}\right.$

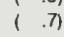

$\left(\begin{array}{ll}1 \\ 1 & .1)\end{array}\right.$

$\left(\begin{array}{ll}1 \\ (\end{array}\right)$

$\left(\begin{array}{l}1 \\ (.6)\end{array}\right.$

$\left(\begin{array}{l}0.0) \\ (0.0) \\ (\quad 1)\end{array}\right.$

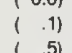

$\left(\begin{array}{ll}1 \\ ( & -5)\end{array}\right.$

$\left(\begin{array}{r}7 \\ (\quad .9)\end{array}\right.$

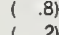

$\begin{array}{ll}( & 2) \\ 1 & .1\end{array}$

\begin{tabular}{|c|c|c|c|}
\hline & & 1.3 & $(4.8)$ \\
\hline $0.0-$ & .8 & .2 & 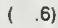 \\
\hline $0.0-$ & .3 & .1 & $(.4)$ \\
\hline \multirow[t]{2}{*}{$0.0-$} & .5 & .1 & $\left(\begin{array}{ll}(4 & 4\end{array}\right)$ \\
\hline & & .0 & ( $\quad .2)$ \\
\hline $0.0-$ & 0.0 & 0.0 & $(0.0)$ \\
\hline \multirow[t]{7}{*}{$0.0-$} & .1 & .0 & $(.1)$ \\
\hline & & 0.0 & $(0.0)$ \\
\hline & & .1 & $(.3)$ \\
\hline & & .0 & ( . .1) \\
\hline & & 0.0 & $(0.0)$ \\
\hline & & .0 & ( . .2) \\
\hline & & .0 & $\left(\begin{array}{l}(2) \\
(2)\end{array}\right.$ \\
\hline \multirow[t]{6}{*}{$0.0-$} & .1 & .0 & ( .1) \\
\hline & & 0.0 & $(0.0)$ \\
\hline & & 0.0 & $(0.0)$ \\
\hline & & 0.0 & $(0.0)$ \\
\hline & & 0.0 & $(0.0)$ \\
\hline & & 0.0 & $(0.0)$ \\
\hline
\end{tabular}

$\begin{array}{rrr}0.0-60.0 & 12.0 & (2.0) \\ 0.0- & (6.0)\end{array}$

$\begin{array}{llll}(.4) & 0.0-20.0 & 8.0 & (4.0) \\ (.4) & 0.0-10.0 & 2.0 & (1.0)\end{array}$

$\begin{array}{lll}(.2) & 2.0 & (1.0)\end{array}$

$\begin{array}{lllll}(0.0) & 0.0- & 0.0 & 0.0 & (0.0)\end{array}$

$\begin{array}{llll}(.1) & 0.0-10.0 & 2.0 & (1.0)\end{array}$

$(0.0)$

(. 3)

$\left(\begin{array}{r}.1) \\ 0.0)\end{array}\right.$

$(0.0)$
$(.2)$

$\begin{array}{ll}( & .2) \\ ( & .2) \\ ( & 11)\end{array}$

$\left(\begin{array}{rl}1 \\ ( \\ (0.0)\end{array}\right)$
$(0.0)$

$(0.0)$

$\left(\begin{array}{l}0.0) \\ (0.0)\end{array}\right.$

$(0.0)$

$\overline{3.000}$

$\overline{26.5}$

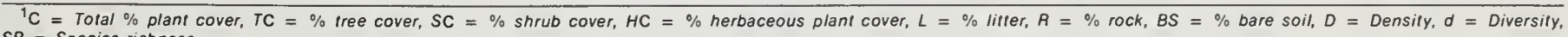
$S A_{2}=$ Species richness.

${ }^{2} B S=100-(H C+L+R)$.
3 Plant species symbol (see Appendix B for full nomenclature).

${ }^{4} \mathrm{~K}=$ Constancy.

${ }^{4} \mathrm{~K}=$ Constancy.
${ }_{\mathrm{TP}}=$ Total percent for species with $\mathrm{IV} \geqslant 0.1$. 
Table 46. - Vegetation and soil surface characteristics for plant community 41 (p.c.41).

Mean ${ }^{1}$

COMMUNITY 41 : Spaj.Hija

$\begin{array}{lllll}\text { SITES } & 28 & 29 & 33 & 67\end{array}$

$\begin{array}{llllllllllll}\text { No. Sites } & \text { No. Trans. } & \frac{\mathrm{C}}{13} & \frac{\mathrm{TC}}{24.3} & \frac{\mathrm{SC}}{0} & \frac{\mathrm{HC}}{23.8} & \frac{\mathrm{L}}{8.0} & \frac{\mathrm{R}}{0} & \frac{\mathrm{BS}^{2}}{68.2} & \frac{\mathrm{D}}{26.8} & \frac{\mathrm{d}}{1.13} & \frac{\mathrm{SR}}{19}\end{array}$

PERCENT COVER

DENSITY

PERCENT FREQUENCY

\begin{tabular}{|c|c|c|c|c|c|c|c|c|c|c|c|c|c|c|c|c|c|}
\hline SPECIES $^{3}$ & $k^{4}$ & RANGE & MEAN & $\%$ TOTAL & $T P^{5}$ & RANGE & MEAN & $\%$ TOTAL & $T P^{5}$ & RANGE & MEAN & $\%$ TOTAL & $T P^{5}$ & RANGE & MEAN & $\%$ TOTAL & $T P^{5}$ \\
\hline SPAI & 4 & $1.514-1.937$ & 1.661 & (55.4) & & $9.9-23.6$ & 18.2 & (74.9) & & $11.9-15.6$ & 13.2 & $(49.4)$ & & $38.0-85.0$ & 65.0 & $(40.8)$ & \\
\hline HIJA & 4 & $.377-1.049$ & .753 & (25.1) & & $1.6-6.6$ & 4.1 & (16.9) & & $5.5-11.5$ & 8.4 & (31.1) & & $30.0-50.0$ & 40.3 & $(25.2)$ & \\
\hline MUTO & 2 & $0.000-.352$ & .105 & ( 3.5$)$ & 84.0 & $0.0-1.5$ & .4 & ( 1.5$)$ & 93.3 & $0.0-7.0$ & 1.9 & ( 7.1$)$ & 87.6 & $0.0-17.0$ & 5.5 & $(3.4)$ & 69.4 \\
\hline SCPA & 3 & $0.000-.235$ & .096 & ( 3.2$)$ & & $0.0-.3$ & .1 & $(.5)$ & & $0.0-2.1$ & .7 & ( 2.5$)$ & & $0.0-28.0$ & 11.5 & $(7.2)$ & \\
\hline BOGR & 3 & $0.000-.220$ & .091 & ( 3.0$)$ & & $0.0-1.0$ & .5 & ( 1.9$)$ & & $0.0-4.4$ & 1.4 & ( 5.3$)$ & & $0.0-10.0$ & 3.8 & (2.4) & \\
\hline SPCR & 3 & $0.000-.214$ & .090 & $(3.0)$ & & $0.0-.8$ & .3 & $(1.2)$ & & $0.0-2.2$ & .8 & ( 2.8$)$ & & $0.0-23.0$ & 10.3 & $(6.4)$ & \\
\hline SIHY & 2 & $0.000-.174$ & .059 & $(2.0)$ & & $0.0-.4$ & .1 & $(.5)$ & & $0.0-.3$ & .1 & $(.4)$ & & $0.0-15.0$ & 6.3 & (3.9) & \\
\hline GUSA & 3 & $0.000-.077$ & .045 & $(1.5)$ & & $0.0-.9$ & .3 & $(1.4)$ & & $0.0-.2$ & .1 & $(.3)$ & & $0.0-7.0$ & 4.3 & (2.7) & \\
\hline AGSM & 2 & $0.000-.117$ & .030 & $(1.0)$ & & $0.0-\quad .0$ & .0 & $(0.0)$ & & $0.0-.5$ & .1 & ( . .5) & & $0.0-20.0$ & 5.0 & (3.1) & \\
\hline ORHY & 3 & $0.000-.054$ & .022 & $(.7)$ & & $0.0-.1$ & .0 & $(.2)$ & & $0.0-.1$ & .0 & $(.1)$ & & $0.0-5.0$ & 2.8 & $(1.7)$ & \\
\hline AGTR & 1 & & .009 & ( . .3) & & & .0 & $(0.0)$ & & & .1 & $(.2)$ & & & 1.3 & $(.8)$ & \\
\hline $\mathrm{OPCL}$ & 1 & & .008 & $(.3)$ & & & .0 & ( .1) & & & .0 & $(.1)$ & & & .8 & $(.5)$ & \\
\hline OPIM & 1 & & .007 & $(.2)$ & & & .1 & $(.4)$ & & & 0.0 & $(0.0)$ & & & 0.0 & $(0.0)$ & \\
\hline ARTR & 1 & & .007 & $(.2)$ & & & .1 & $(.2)$ & & & .0 & ( . .1) & & & .8 & $(.5)$ & \\
\hline OPPO & 1 & & .006 & $(.2)$ & & & 0.0 & $(0.0)$ & & & .0 & $(0.0)$ & & & .8 & 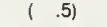 & \\
\hline ATCA & 2 & $0.000-.018$ & .006 & $(.2)$ & & $0.0-\quad .1$ & .0 & ( . .1) & & $0.0-\quad .0$ & .0 & $(0.0)$ & & $0.0-3.0$ & .8 & ( . .5) & \\
\hline SAVE2 & 1 & & .005 & $(.2)$ & & & 0.0 & $(0.0)$ & & & .0 & (. .1) & & & .8 & 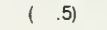 & \\
\hline CRYP & 1 & & .001 & $(0.0)$ & & & .0 & ( . .1) & & & 0.0 & $(0.0)$ & & & 0.0 & $(0.0)$ & \\
\hline \multirow[t]{2}{*}{ BACC } & 1 & & .001 & $(0.0)$ & & & .0 & (. .1) & & & 0.0 & $(0.0)$ & & & 0.0 & $(0.0)$ & \\
\hline & & & 2.999 & & & & 24.3 & & & & 26.8 & & & & & & \\
\hline
\end{tabular}

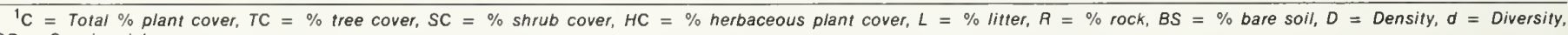
$S R=$ Species richness.

${ }^{2} B S=100-(H C+L+R)$.

${ }_{4}^{3}$ Plant species symbol (see Appendix B for full nomenclature)

${ }^{4} K=$ Constancy.

${ }^{5} T P=$ Total percent for species with $N \geqslant 0.1$.

Table 47,-Vegetation and soil surface characteristics for plant community 42 (p.c. 42).

COMMUNITY 42 : Gusa/Spai.HIja

SITES $\quad 109 \quad 156$

$\operatorname{Mean}^{1}$

$\begin{array}{lllllllllllll}\text { No. Sites } & \text { No. Trans. } & \frac{\mathrm{C}}{6} & \frac{\mathrm{TC}}{8.6} & \frac{\mathrm{SC}}{3.8} & \frac{\mathrm{HC}}{4.8} & \frac{\mathrm{L}}{5.3} & \frac{\mathrm{A}}{2.3} & \frac{\mathrm{BS}^{2}}{87.6} & \frac{\mathrm{D}}{14.8} & \frac{d}{1.62} & \frac{\mathrm{SR}}{22}\end{array}$

IMPORTANCE VALUE

PERCENT COVER DENSITY

PERCENT FREQUENCY

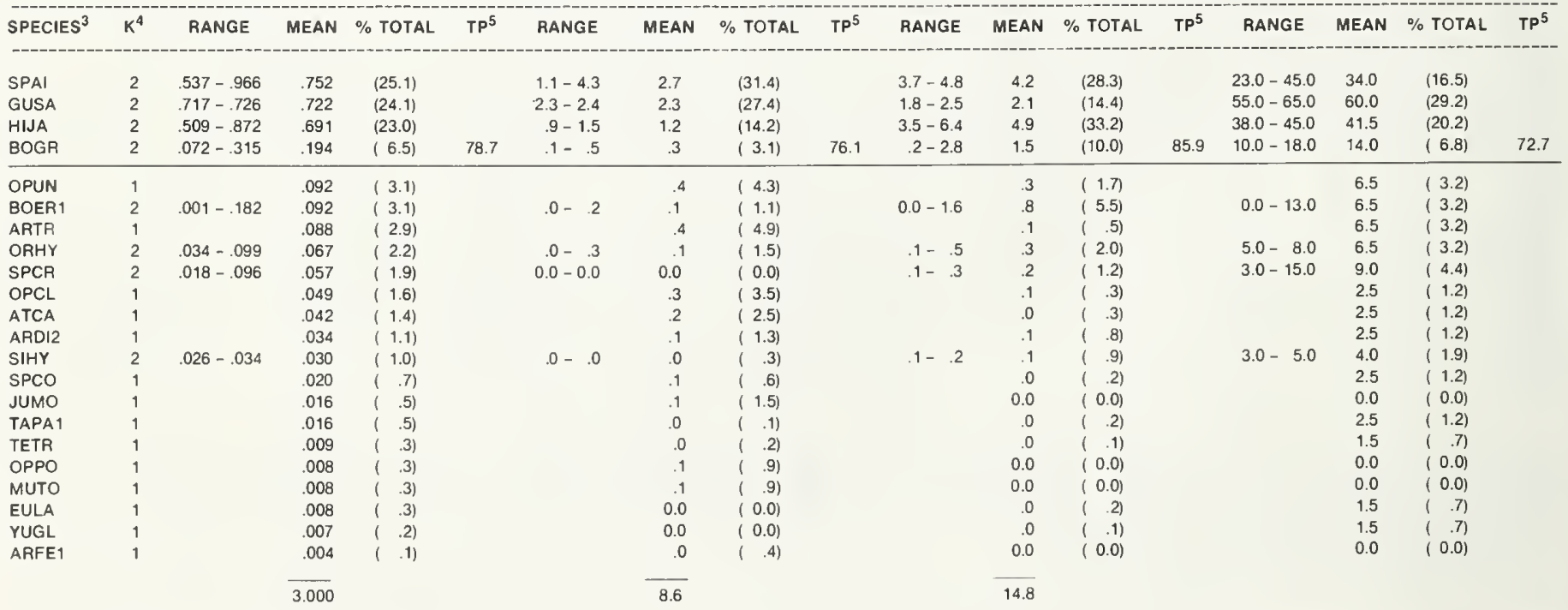

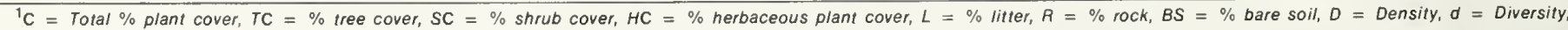
$S R=$ Species richness.

${ }^{2} B S=100-(H C+L+R)$.

${ }^{3}$ Plant species symbol (see Appendix B for full nomenclature).

${ }^{4} K=$ Constancy.

${ }^{5} \mathrm{TP}=$ Total percent for species with $\mathrm{N} \geqslant 0.1$ 
Table 48. - Vegetation and soil surface characteristics for plant community 43 (p.c.43).

Mean ${ }^{1}$

COMMUNITY 43 : Spal-Agsm

SITES

$34 \quad 76$

IMPORTANCE VALUE

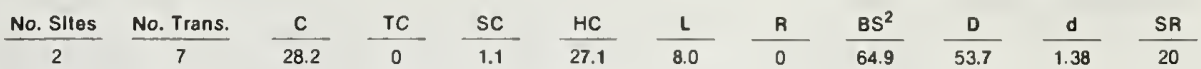

PERCENT COVER

DENSITY

PERCENT FREQUENCY

\begin{tabular}{|c|c|c|c|c|c|c|c|c|c|c|c|c|c|c|c|c|c|}
\hline SPECIES $^{3}$ & $K^{4}$ & RANGE & MEAN & $\%$ TOTAL & $T P^{5}$ & RANGE & MEAN & $\%$ TOTAL & $T P^{5}$ & RANGE & MEAN & $\%$ TOTAL & $T P^{5}$ & RANGE & MEAN & $\%$ TOTAL & $T P^{5}$ \\
\hline SPAI & 2 & $.701-1.984$ & 1.343 & $(44.7)$ & & $6.9-29.5$ & 18.2 & $(64.6)$ & & $12.7-14.4$ & 13.6 & (25.2) & & $68.0-73.0$ & 70.5 & (31.2) & \\
\hline AGSM & 2 & $.329-.697$ & .513 & (17.1) & & $1.9-4.1$ & 3.0 & (10.7) & & $2.5-23.3$ & 12.9 & $(24.0)$ & & $23.0-73.0$ & 48.0 & (21.2) & \\
\hline BOGR & 1 & & .306 & $(10.2)$ & & & 2.1 & ( 7.3$)$ & & & 14.3 & $(26.7)$ & & & 15.0 & (6.6) & \\
\hline SPCR & 2 & $.078-.345$ & .212 & $(7.0)$ & & $.3-.4$ & .4 & (1.3) & & $.5-2.8$ & 1.6 & (3.1) & & $18.0-30.0$ & 24.0 & $(10.6)$ & \\
\hline MURI1 & 1 & & .179 & $(6.0)$ & & & 1.5 & ( 5.3$)$ & & & 5.8 & $(10.7)$ & & & 14.0 & (6.2) & \\
\hline HIJA & 2 & $.006-.210$ & .108 & ( 3.6$)$ & 88.6 & $.2-2.1$ & 1.1 & $(4.0)$ & 93.2 & $0.0-6.6$ & 3.3 & $(6.1)$ & 95.8 & $0.0-13.0$ & 6.5 & ( 2.9) & 78.7 \\
\hline SCPA & 1 & & .088 & (2.9) & & & .4 & ( 1.6$)$ & & & 1.1 & ( 2.0$)$ & & & 16.5 & ( 7.3) & \\
\hline GUSA & 2 & $.018-.116$ & .067 & (2.2) & & $0.0-.6$ & .3 & (1.1) & & $.1-\quad .3$ & .2 & ( . .3) & & $5.0-13.0$ & 9.0 & $(4.0)$ & \\
\hline SIHY & 2 & $.024-.048$ & .036 & (1.2) & & $.0-.2$ & .1 & $(.4)$ & & $.0-\quad .4$ & .2 & $(.4)$ & & $3.0-10.0$ & 6.5 & ( 2.9$)$ & \\
\hline SPIN & 1 & & .035 & (1.2) & & & 0.0 & $(0.0)$ & & & .5 & ( .9) & & & 1.5 & ( .7) & \\
\hline $\mathrm{CHVI3}$ & 1 & & .028 & ( . .9) & & & .5 & ( 1.9$)$ & & & .0 & $(0.0)$ & & & 1.5 & $(.7)$ & \\
\hline AGCR & 1 & & .020 & $(.7)$ & & & .2 & $(.7)$ & & & .1 & $\left(\begin{array}{l}(2) \\
\text { ( })\end{array}\right.$ & & & 1.5 & $(.7)$ & \\
\hline ATCA & 1 & & .018 & ( . .6) & & & .2 & ( . .8) & & & .0 & $(0.0)$ & & & 1.5 & ( . .7) & \\
\hline SPHA & 1 & & .014 & $(.5)$ & & & .0 & $(0.0)$ & & & .1 & ( . .1) & & & 4.0 & ( 1.8$)$ & \\
\hline UKDIC & 1 & & .012 & $(.4)$ & & & 0.0 & $(0.0)$ & & & .0 & $(.1)$ & & & 1.5 & $(.7)$ & \\
\hline ALCE & 1 & & .012 & ( . .4) & & & 0.0 & $(0.0)$ & & & .0 & $(0.0)$ & & & 1.5 & ( . .7) & \\
\hline $\mathrm{MACH}$ & 1 & & .005 & (. .2) & & & 0.0 & $(0.0)$ & & & .1 & ( . .1) & & & 1.5 & $(.7)$ & \\
\hline LEER & 1 & & .005 & ( . .1) & & & 0.0 & $(0.0)$ & & & .0 & $(0.0)$ & & & 1.5 & $(.7)$ & \\
\hline OPPO & 1 & & .002 & $(0.0)$ & & & .1 & ( . .2) & & & 0.0 & $(0.0)$ & & & 0.0 & $(0.0)$ & \\
\hline MUTO & 1 & & .002 & $(0.0)$ & & & .0 & $(.1)$ & & & 0.0 & $(0.0)$ & & & 0.0 & $(0.0)$ & \\
\hline & & & 3.001 & & & & 28.2 & & & & 53.7 & & & & & & \\
\hline
\end{tabular}

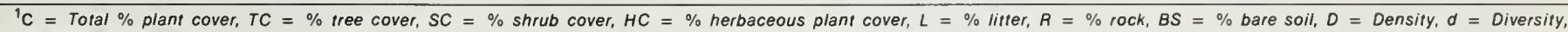
$S R=$ Species richness.

${ }^{2} B S=100-(H C+L+R)$.

${ }^{3}$ Plant species symbol (see Appendix B for full nomenclature)

${ }^{4} \mathrm{~K}=$ Constancy.

${ }^{5} T P=$ Total percent for species with $I V \geqslant 0.1$

Table 49. - Vegetation and soil surface characteristics for plant community 44 (p.c.44).

COMMUNITY 44 : Spne.Boer

SITES $\quad 39$

Mean ${ }^{1}$

\begin{tabular}{|c|c|c|c|c|c|c|c|c|c|c|c|c|c|c|c|c|c|}
\hline \multirow[b]{2}{*}{ SPECIES $^{3}$} & \multirow[b]{2}{*}{$k^{4}$} & \multicolumn{3}{|c|}{ IMPORTANCE VALUE } & \multicolumn{5}{|c|}{ PERCENT COVER } & \multicolumn{4}{|c|}{ DENSITY } & \multicolumn{4}{|c|}{ PERCENT FREQUENCY } \\
\hline & & RANGE & MEAN & $\%$ TOTAL & $T P^{5}$ & RANGE & MEAN & $\%$ TOTAL & $T P^{5}$ & RANGE & MEAN & $\%$ TOTAL & $T P^{5}$ & RANGE & MEAN & $\%$ TOTAL & $T P^{5}$ \\
\hline SPNE1 & 1 & & .777 & $(25.9)$ & & & 2.5 & $(30.2)$ & & & 2.4 & $(27.4)$ & & & 40.0 & $(20.0)$ & \\
\hline LEPT & 1 & & .760 & $(25.3)$ & & & 2.7 & $(32.7)$ & & & 1.6 & $(18.3)$ & & & 50.0 & $(25.0)$ & \\
\hline BOER1 & 1 & & .401 & (13.4) & & & 1.1 & $(13.0)$ & & & 1.5 & $(17.1)$ & & & 20.0 & $(10.0)$ & \\
\hline HIJA & 1 & & .371 & (12.4) & & & .3 & (3.1) & & & 2.1 & $(24.0)$ & & & 20.0 & $(10.0)$ & \\
\hline EPTO & 1 & & .173 & $(5.8)$ & & & .9 & (11.1) & & & .1 & ( 1.1$)$ & & & 10.0 & $(5.0)$ & \\
\hline CELA & 1 & & .152 & $(5.1)$ & 87.9 & & .3 & ( 3.7$)$ & 93.8 & & .4 & $(4.0)$ & 91.9 & & 15.0 & $(7.5)$ & 77.5 \\
\hline PSTA & 1 & & .067 & $(2.2)$ & & & 0.0 & $(0.0)$ & & & .2 & ( 1.7$)$ & & & 10.0 & $(5.0)$ & \\
\hline GUSA & 1 & & .061 & $(2.0)$ & & & 0.0 & $(0.0)$ & & & .1 & $(1.1)$ & & & 10.0 & $(5.0)$ & \\
\hline BOGR & 1 & & .054 & $(1.8)$ & & & 0.0 & $(0.0)$ & & & .3 & ( 2.9$)$ & & & 5.0 & $(2.5)$ & \\
\hline LYPA1 & 1 & & .043 & $(1.4)$ & & & .1 & $(1.2)$ & & & .1 & $(.6)$ & & & 5.0 & $(2.5)$ & \\
\hline MUHL & 1 & & .037 & $(1.2)$ & & & .1 & $(.6)$ & & & .1 & $($ ( .6) & & & 5.0 & (2.5) & \\
\hline SPCR & 1 & & .031 & $(1.0)$ & & & 0.0 & $(0.0)$ & & & .1 & $(.6)$ & & & 5.0 & $(2.5)$ & \\
\hline CovI & 1 & & .031 & $(1.0\rangle$ & & & 0.0 & $(0.0)$ & & & .1 & $\left(\begin{array}{l}( \\
(\end{array}\right)$ & & & 5.0 & ( 2.5$)$ & \\
\hline SPCO & 1 & & .025 & $(.8)$ & & & .2 & $(2.5)$ & & & 0.0 & $(0.0)$ & & & 0.0 & $(0.0)$ & \\
\hline ARLO1 & 1 & & .012 & (. .4) & & & .1 & $(1.2)$ & & & 0.0 & $(0.0)$ & & & 0.0 & $(0.0)$ & \\
\hline LEER & 1 & & .006 & ( . .2) & & & .1 & ( .6) & & & 0.0 & $(0.0)$ & & & 0.0 & $(0.0)$ & \\
\hline & & & 3.001 & & & & 8.1 & & & & 8.8 & & & & & & \\
\hline
\end{tabular}

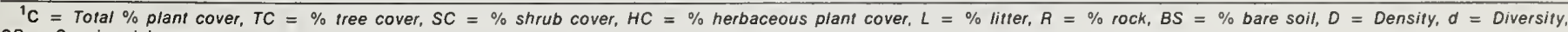
$S R_{2}=$ Species richness.

${ }_{3} B S=100-(H C+L+R)$.
3 Plani species symbol (see Appendix $B$ for full nomenclature).

${ }^{3} P l a n t$ species symb
${ }^{4} K=$ Constancy.

${ }^{5} T P=$ Total percent for species with $I V \geqslant 0.1$. 
Table 50. - Vegetation and soil surface characteristics for plant community 45 (p.c.45)

COMMUNITY 45 : Scbr.Bogr

SITES $\quad 41$

41

Mean $^{1}$

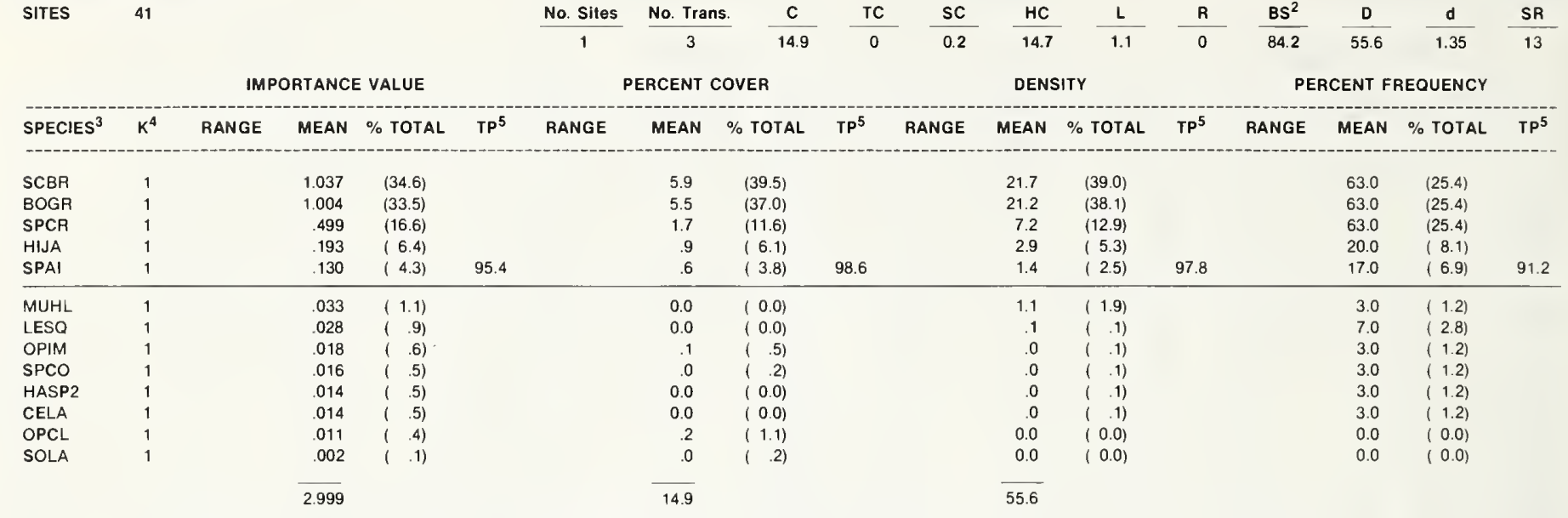

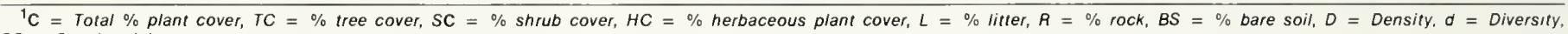
$S R=$ Species richness.

${ }_{3}^{B S}=100-(H C+L+R)$.
${ }^{4}$ Piant species symbol (see Appendix B for full nomenclature).

${ }^{4} K=$ Constancy.

${ }^{5} T P=T$ otal percent for species with $I V \geqslant 0.1$. 


\section{APPENDIX A}

Modal soil profiles of the Upper Rio Puerco Watershed. Soil orders, series, associations, and complexes adapted from Folks and Stone (1968), and an unpublished survey ${ }^{5}$. Horizon and texture designations follow soil taxonomy nomenclature (Soil Survey Staff 1975).

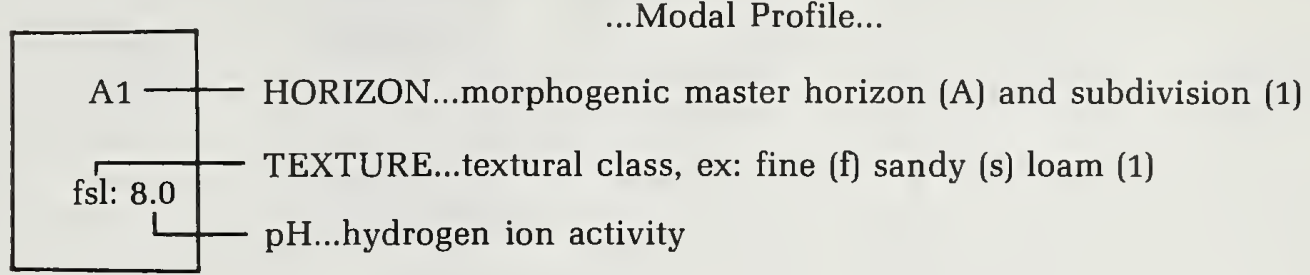

...Modal Profile...

\section{ENTISOL}

\section{SERIES: TRAVESSILLA \\ SHINGLE \\ PERSAYO}

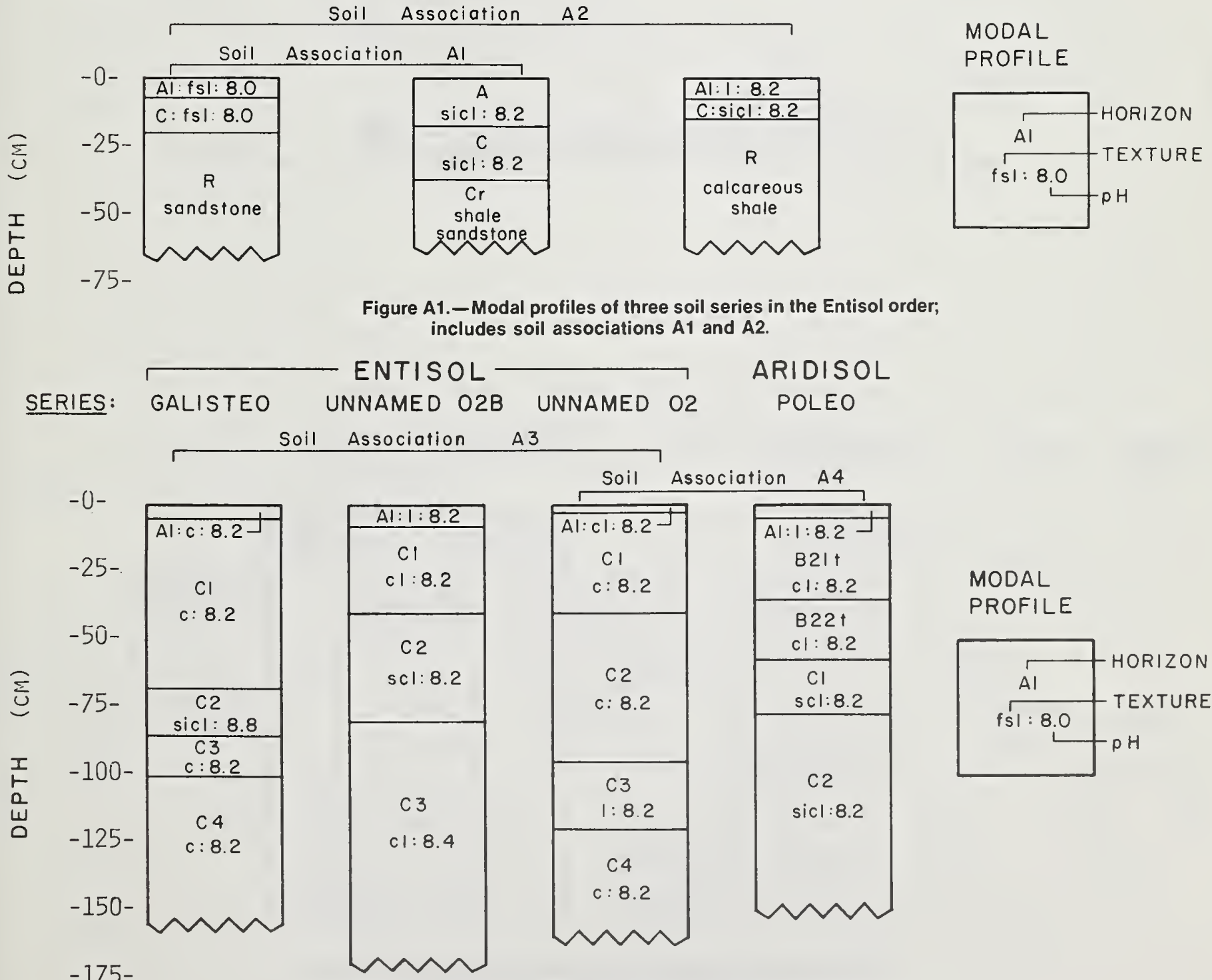

Figure A2. - Modal profiles of four soil series in the Entisol and Aridisol orders; includes soil associations A3 and A4. 


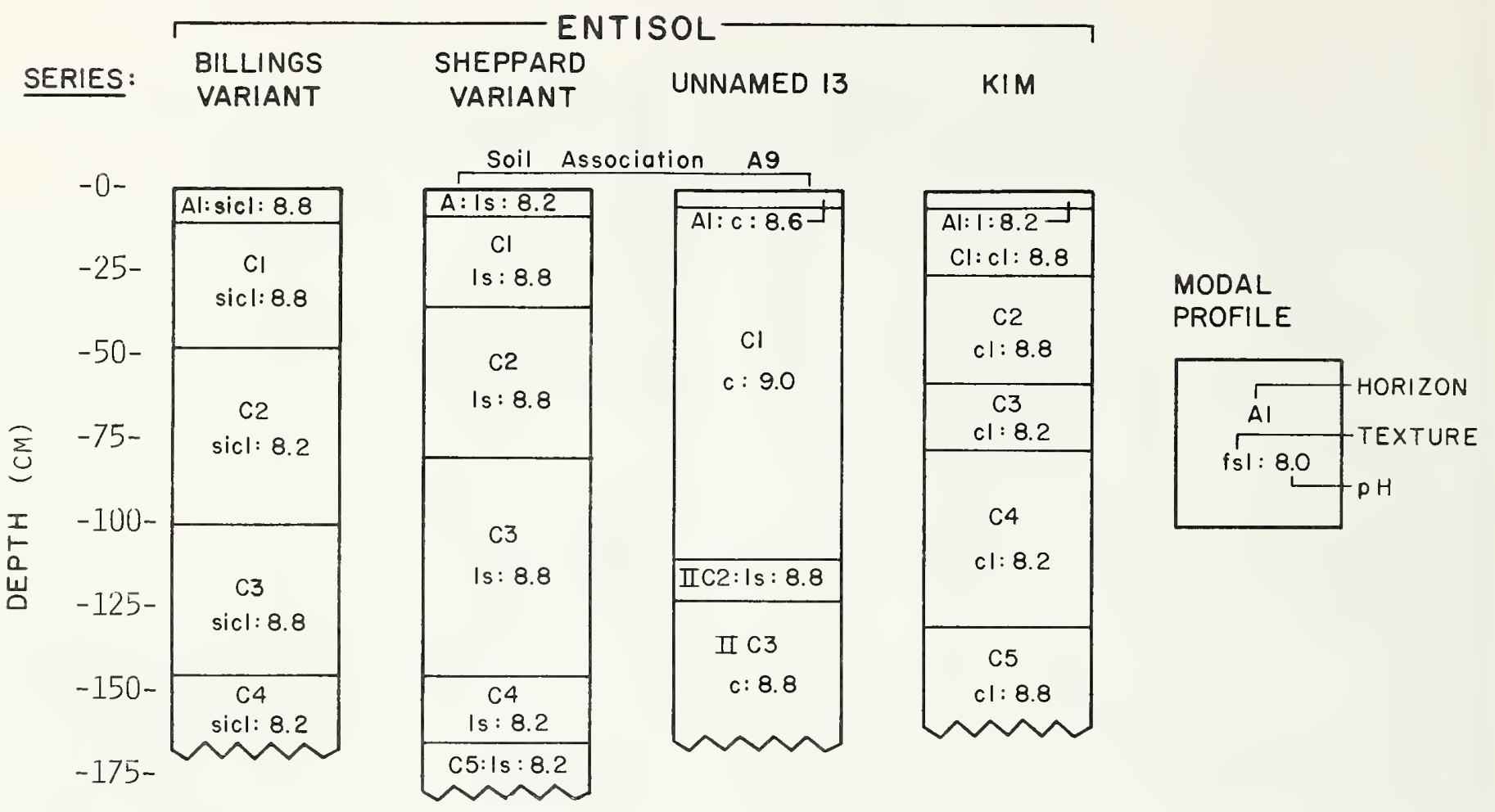

Figure A3.-Modal profiles of four soil series in the Entisol order; includes soil association A9.

ENTISOL

\section{SERIES: RAVOLA CHRISTAINBURG BERENT FRUITLAND NAVAJO}
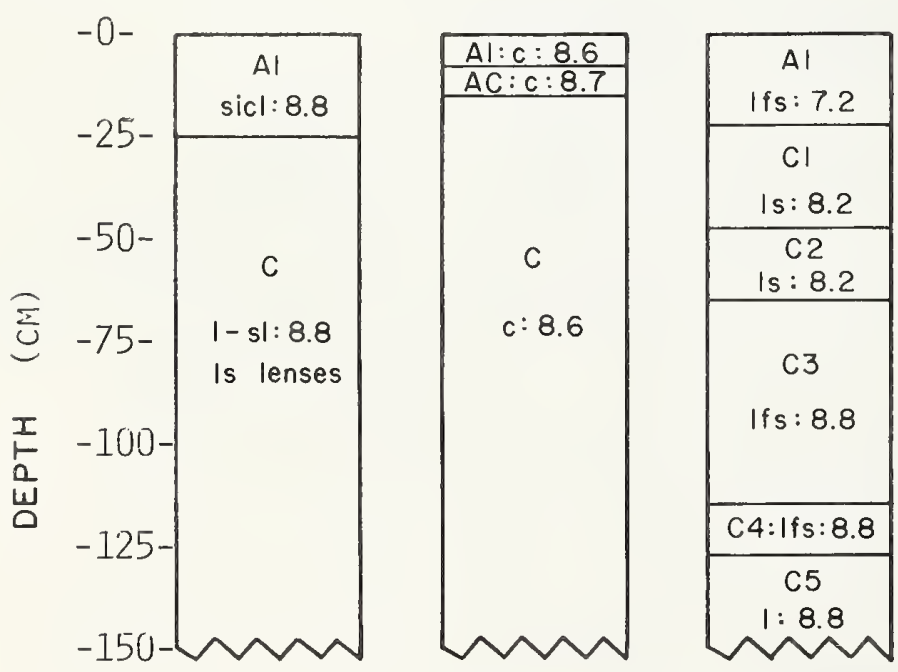

\begin{tabular}{|c|}
\hline All:sl: 7.6 \\
\hline Al2:hvy:sl:7.6 \\
\hline AC:sl: 7.6 \\
\hline Cl:hvy.|s:7.6 \\
\hline C2 \\
sl: 7.6 \\
\hline c3 7.6 \\
\hline
\end{tabular}

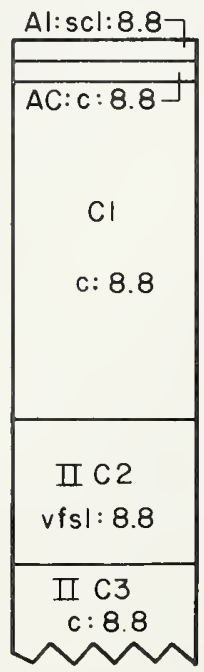

MODAL

PROFILE

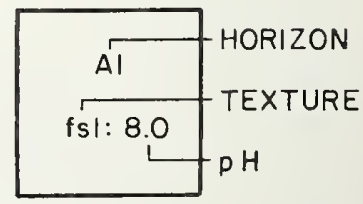

Figure A4. - Modal profiles of five soil series in the Entisol order. 


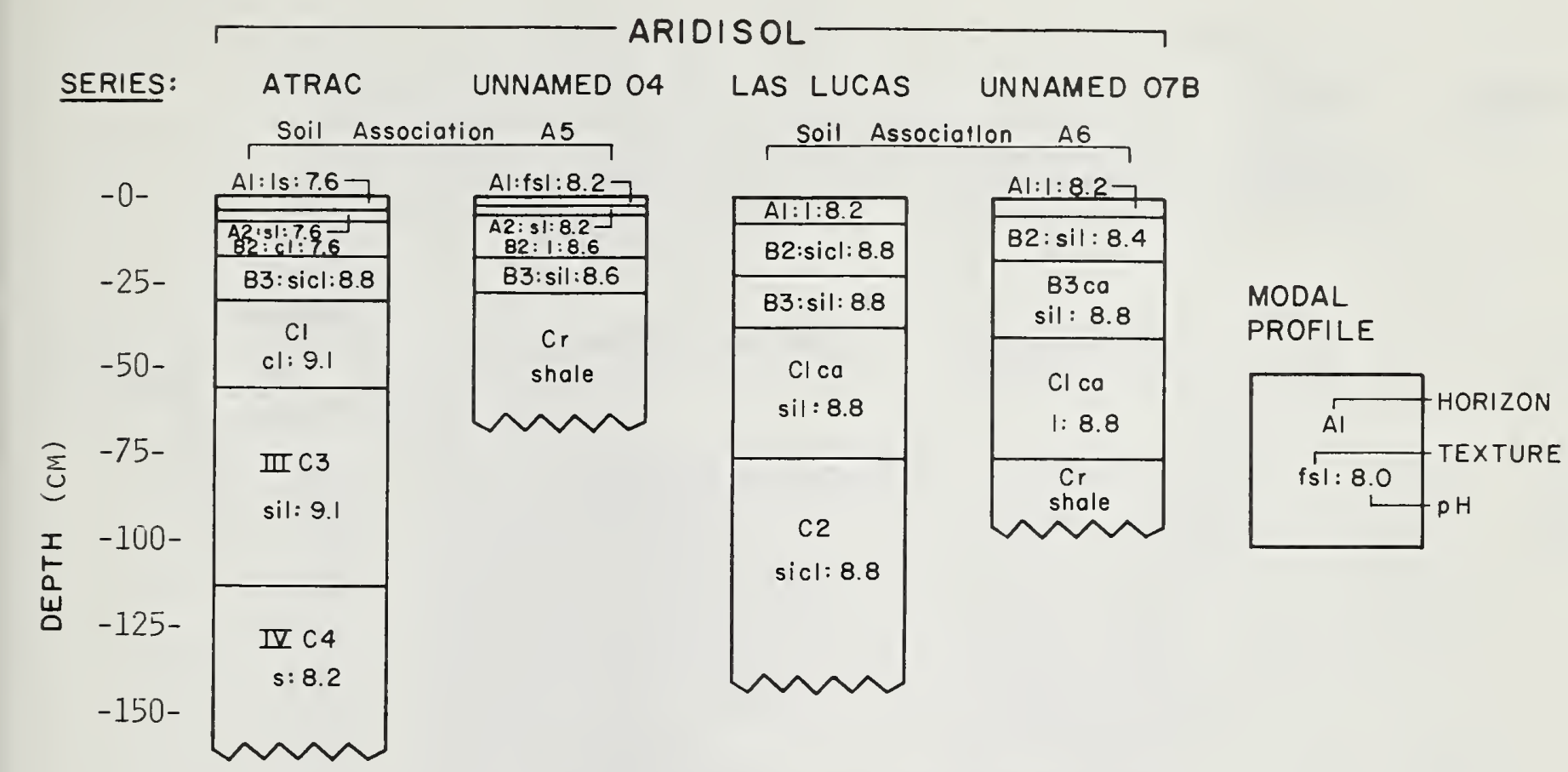

Figure A5. - Modal profiles of four soil series in the Aridisol order; includes soil associations $\mathbf{A 5}$ and $\mathbf{A 6}$.

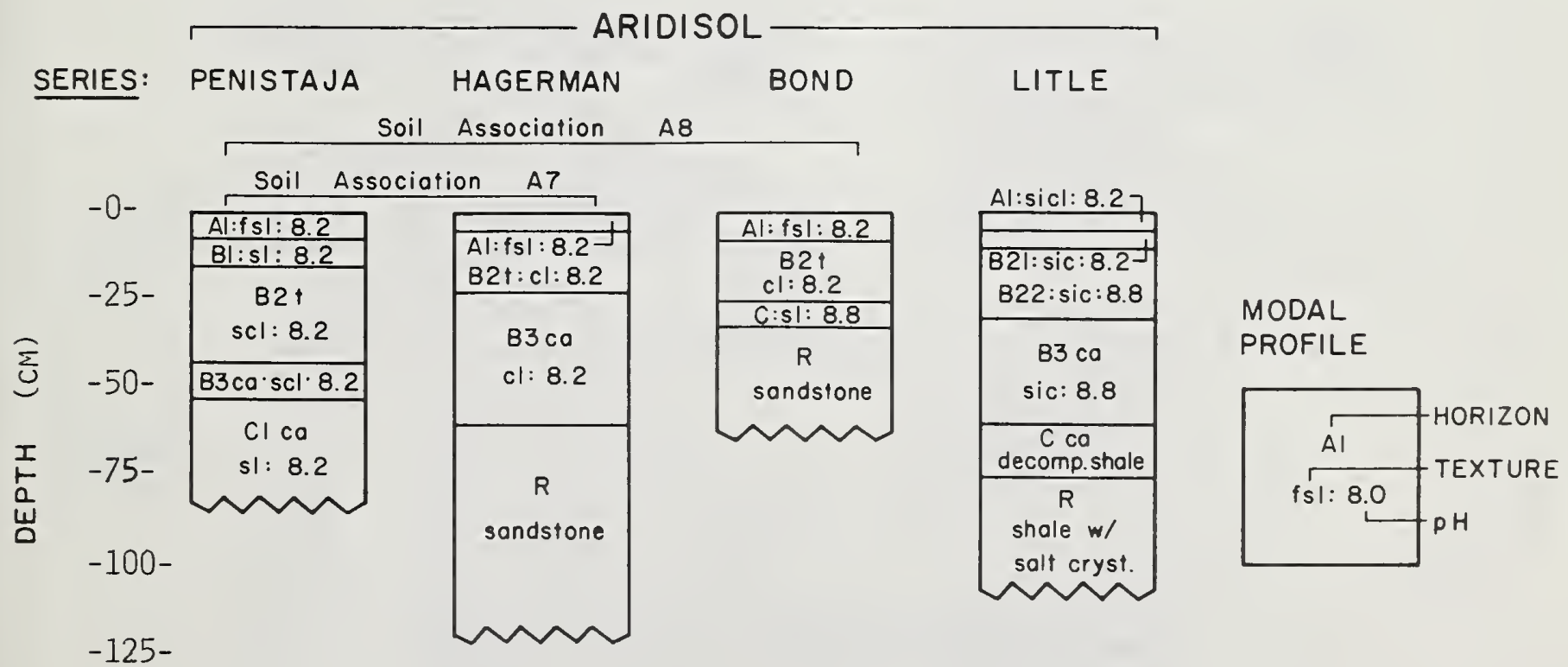

Figure A6. - Modal profiles of four soil series in the Aridisol order; includes soil associations $A 7$ and $A 8$. 
MOLLISOL

SERIES: PREWITT

CABEZON

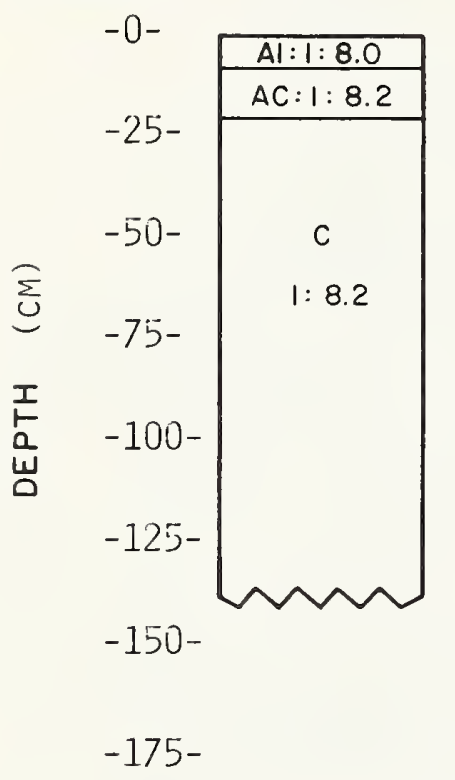

\section{ALLUVIAL}

\begin{tabular}{|c|}
\hline Al:sil: 7.0 \\
\hline B21 \\
C: 7.0 \\
\hline$R$ \\
basalt \\
\hline
\end{tabular}

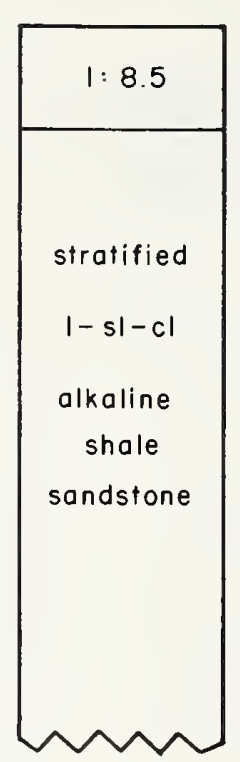

MODAL PROFILE

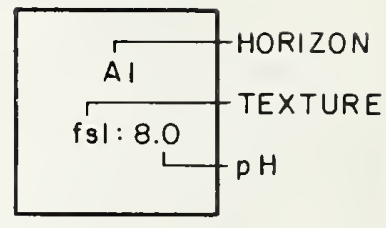

Figure A7.-Modal profiles of two soil series in the Mollisol order, and Alluvial land.

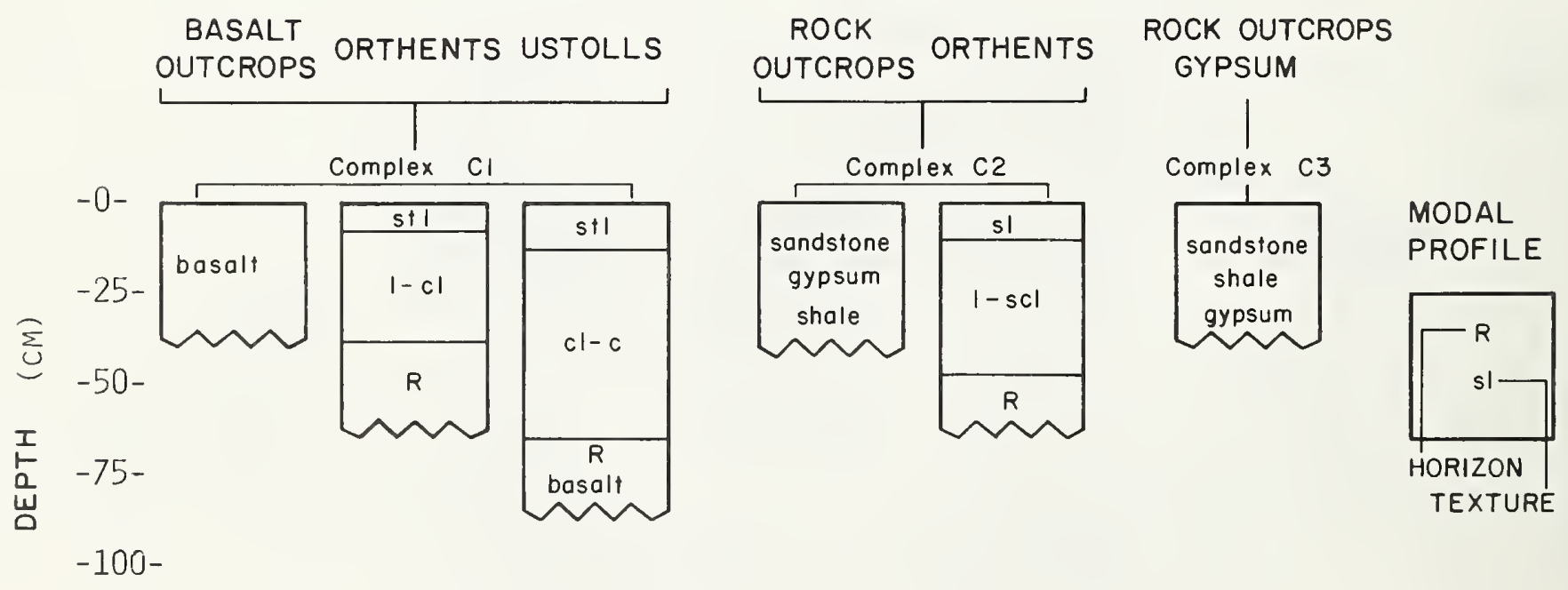

Flgure A8.-Modal profiles of three soil complexes: C1, C2, C3. 


\section{APPENDIX B}

Plant species of the Upper Rio Puerco Watershed. Most symbols and names follow Nickerson et al. 1976; others follow Martin and Hutchins 1980. Common names in parentheses are unofficial. Upper and lower case symbols represent the first two letters of the genus and species; upper case symbols represent the first four letters of the genus or family.

\section{Species}

Symbol Scientific Name and Authority

\section{Common Name}

\section{Trees and shrubs}

Aloc Allenrolfea occidentalis (Wats.)Kuntze

Arbi1 Artemisia biennis Willd.

Arbi2 Artemisia bigelovii Gray

Arca Artemisia cana Pursh

Ardr2 Artemisia dracunculoides Pursh

Arfi Artemisia filifolia Torr.

Arfr1 Artemisia frigida Willd.

Arlu Artemisia ludoviciana Nutt.

Arno Artemisia nova A.Nels.

Artr Artemisia tridentata Nutt.

Atca Atriplex canescens (Pursh)Nutt.

Atco Atriplex confertifolia

(Torr. + Frem.)Wats.

Atcu Atriplex cuneata A.Nels

Atob Atriplex obovata Moq.

Cela Ceratoides lanata (Pursh)Moq.

Cemo Cercocarpus montanus Raf.

Chde

Chgr

Chna

Chnab

Chnag

Chnac

Chpa3

Chvi3

Chrysothamnus depressus Nutt.

Chrysothamnus greenei (Gray)Greene

Chrysothamnus nauseosus

ssp. bigelovii (Gray)H. + C.

ssp. graveolens (Nutt.)H. $+\mathrm{C}$.

ssp. consimilis (Greene)H. + C.

Chrysothamnus parryi (Gray)Greene

Chrysothamnus viscidiflorus

(Hook.)Nutt.

Epto Ephedra torreyana Wats.

Epvi Ephedra viridis Cov.

Eula

Eurotia lanata (Pursh) Moq.

Frja Frankenia jamesii Torr.

Gusa Guiterrezia sarothrae (Pursh)

Britt. + Rusby

$=$ Xanthocephalum sarothrae Gray

Jumo Juniperus monosperma (Engelm.)Sarg.

Lypa1 Lycium pallidum Miers

OPUN Opuntia spp.

Opcl

Open

Opim

Opph

Oppo

Pamy

Opuntia clavata Engelm.

Opuntia engelmannii Salm-Dyck

Pied

Opuntia imbricata (Haw.)DC.

Pipo

Opuntia phaeacantha Engelm.

Opuntia polyacantha Haw.

Pinus edulis Engelm.

Psme

Quga

Qugr

Pachistima myrsinites (Pursh)Raf.

Pinus ponderosa Laws.

Pseudotsuga menziesii (Mirb.)Franco

Quercus gambelii Nutt.

Quercus grisea Liebm.

pickleweed

biennial sagebrush

Bigelow sagebrush

silver sagebrush

false tarragon

sand sagebrush

fringed sagebrush

Louisiana sagebrush

black sagebrush

big sagebrush

fourwing saltbush

shadscale saltbush

moundscale

(scurfy) saltbush

winterfat

true mountainmahogany

dwarf rabbitbrush

Greenes rabbitbrush

rubber rabbitbrush

(Bigelow) rabbitbrush

Parry rabbitbrush

Douglas rabbitbrush

Torrey jointfir

green ephedra

winterfat

Frankenia

broom snakeweed

one-seed juniper

pale wolfberry

prickly pear

club cholla

Engelmann prickly pear

plains prickly pear

myrtle pachistima

pinyon pine

ponderosa pine

Douglas-fir

gambel oak

gray oak 
Quun Quercus undulata Torr.

Save2 Sarcobatus vermiculatus (Hook.)Torr.

TETR Tetradymia spp.

Vasc Vaccinium scoparium Leiberg

YUCC Yucca spp.

Yuba Yucca baccata Torr.

Yuel Yucca elata Engelm.

Yugl Yucca glauca Nutt.

Forbs

\begin{tabular}{|c|c|}
\hline Abel & Abronia elliptica A.Nels \\
\hline Acla & Achillea lanulosa Nutt. \\
\hline ACTA & Actaea spp. \\
\hline AGOS & Agoseris spp. \\
\hline Agau & Agoseris aurantiaca (Hook.)Greene \\
\hline ALLI & Allium spp. \\
\hline Alce & Allium cernuum Roth \\
\hline Alte & Allium textile Nels. + Macbr. \\
\hline Amps & Ambrosia psilostachya DC. \\
\hline ANTE & Antennaria spp. \\
\hline Anro & Antennaria rosea (D.C. Eat.)Greene \\
\hline Anro1 & Antennaria rosulata Rydb. \\
\hline Anse & Androsace septentrionalis L. \\
\hline ARAB & Arabis spp. \\
\hline Ardr1 & Arabis drummondii Gray \\
\hline Arfe2 & Arenaria fendleri (Wats.)Greene \\
\hline Arlas & $\begin{array}{l}\text { Arenaria lanuginosa saxosa } \\
\text { (Gray)Maguire (ssp.) }\end{array}$ \\
\hline Asce & Astragalus ceramicus Sheld. \\
\hline ASCL & Asclepias spp. \\
\hline Assu & Asclepias subverticellata (Gray)Vail \\
\hline ASTE & Aster spp. \\
\hline ASTR & Astragalus spp. \\
\hline Asfl2 & Astragalus flavus Nutt. \\
\hline Asfl1 & Astragalus flexuosus (Hook.)G.Don \\
\hline Astr1 & Astragalus gracilis Nutt. \\
\hline BORA & Boragenaceae \\
\hline Caha & Calylophus hartwegii (Benth.)Raven \\
\hline Caro1 & Campanula rotundifolia $\mathrm{L}$. \\
\hline CAST & Castillija spp. \\
\hline Cach & Castilleja chromosa A.Nels. \\
\hline Chvi2 & Chrysopsis villosa (Pursh)DC. \\
\hline Clse & Cleome serrulata Pursh \\
\hline Cowr & Cordylanthus wrightii Gray \\
\hline CORE & Coreopsis spp. \\
\hline Covi & $\begin{array}{l}\text { Coryphantha vivipara (Nutt.) } \\
\text { Britt. + Rose }\end{array}$ \\
\hline Crce & Cryptantha celosiodes (Eastw.)Pays \\
\hline Crfu & Cryptantha fulvocanescens (Gray)Pays \\
\hline CRUC & Cruciferae \\
\hline CRYP & Cryptantha spp. \\
\hline CYMO & Cymopterus spp. \\
\hline DALE & Dalea spp. \\
\hline Deob & Descurainia obtusa \\
\hline Diwi & Dithyrea wislizenii Engelm. \\
\hline Ectr & Echinocereus triglochidiatus Engelm. \\
\hline ERIG & Erigeron spp. \\
\hline Erco2 & Erigeron concinnus T \\
\hline Erfl1 & Erigeron flagellaris $\mathrm{Gr}$ \\
\hline Erfo & Erigeron formosissin \\
\hline
\end{tabular}

wavyleaf (scrub) oak black greasewood horsebrush grouse whortleberry yucca species

soaptree yucca small soapweed

pink sandverbena western yarrow baneberry agoseris orange agoseris onion nodding onion textile onion western ragweed pussytoes rose pussytoes pussytoes rockjasmine rockcress Drummond rockcress Fendler sandwort

loco

milkweed

horsetail milkweed aster

loco

yellow milkvetch

flexile milkvetch slender milkvetch borage family calyophus bluebell paintbrush (colorful) paintbrush hairy goldaster bee spiderflower wright birdsbeak coreopsis (tickseed)

pincusion cactus desert hidden flower beggarlice hidden flower mustard spp. hidden flower wafer-parsnip dalea spp. desert tansy mustard spectaclepod hedgehog cactus fleabane spp. fleabane trailing fleabane 
ERIO1 Eriogonum spp.

Erja Eriogonum jamesii Benth.

Erle Eriogonum leptophyllum (Torr.)

Woot. + Standl.

Erlo1 Eriogonum lonchophyllum $\mathrm{T}+\mathrm{G}$.

Ermi Eriogonum microthecum Nutt.

EUPH Euphorbia spp.

Gaco Gaura coccinea (Nutt.)Pursh.

Gavi

GERA

GILI

Gilo

Gimu

GRIN

Grap

Grar

Hacu

Hagr

Hasp2

Heca8

Hequ

Horu

HYME 1

Hyac

Hylu

Hyro

Hyod

Hyri

Laar

Lale

Lemo

Lepu

LESQ

Lere

Leer

Lile

Lipu

LUPI

Mabi

Maca1

Mela

Meof

MENT

Mepu

Mesa

MIRA

Mili

Mimu

Mope2

Oeco

OROB

Ormu

Peca

PENS

Phlo

PHYS

Phvi

Poal

Pogr2

Pohi

Popu
Gaura villosa Torr.

Geranium spp.

Gilia spp.

Gilia longiflora (Torr.)G.Don

Gilia multiflora (Nutt.)V.Grant

Grindelia spp.

Grindelia apanactis Rydb.

Grindelia arizonica Gray

Haplopappus cuneatus Gray

Haplopappus gracilis (Nutt.)Gray

Haplopappus spinulosus (Pursh.)DC

Heterotheca canescans Wagerknecht

Helianthella quinquenervis (Hook.)Gray

Hymenoxys spp.

Hymenoxys acaulis (Pursh.)Parker

Hymenopappus lugens Greene Jeps.

Hymenopappus robustus Greene

Hymenoxys odorata DC.

Hymenoxys richardsonii (Hook.)Cockll.

Larthrus arixonicus Britt.

Lathyrus leucanthus Rydb.

Lepidium montanum Nutt.

Leptodacctylon pungens (Torr.)Rydb.

Lesquerella spp.

Lesquerella rectipes Woot.+Standl.

Leucelene ericoides (Torr.) Greene

Linum lewisii Pursh

Linum puberulum (Engelm.)Heller

Lupinus spp.

Machaeranthera begelovii (Gray)Greene

Machaeranthera canescens (Pursh)Gray

Mertensia lanceolata (Pursh)A.DC.

Melilotus officinalis (L.)Lam.

Mentzelia spp.

Mentzelia pumila (Nutt.)T. + G.

Medicago sativa L.

Mirabilis spp.

Mirabilis linearis (Pursh)Heimerl

Mirabilis multiflora (Torr.)Gray

Monarda pectinata Nutt.

Oenothera coronopifolia T. +G.

Orobanche spp.

Orbanche multiflora Nutt.

Petalostemon candidum Michx.

Penstemon spp.

Phlox longifolia Nutt.

Physalis spp.

Physalis virginiana mill.

Polygala alba Nutt.

Potentilla hippiana Lehm.

Potentilla pulcherrima Lehm.
Houstonia rubra Cav.

Potentilla gracilia Hook. buckwheat spp.

James eriogonum

spearleaf eriogonum

slenderbush buckwheat

euphorbia (spurge)

scarlet gaura

geranium

gilia

longflower gilia

(cluster flower) gilia

gumweed spp.

(pinnate) gumweed

Arizona gumweed

wedgeleaf goldenweed

ironplant goldenweed

telegraph plant

fivenerve helianthella

bluets

hymenoxys

stemless rubberweed

(red-bract) ragweed

(curly) ragweed

bitterweed hymenoxys

pinque

Arizona peavine

aspen peavine

mountain pepperweed

prickly phlox

bladderpod

baby white aster

Lewis flax

hairy flax

lupine

Bigelow aster

hoary aster

lanceleaf bluebells

yellow sweet clover

mentzelia (stickleaf)

golden blazing star

alfalfa

four-o'clock

four-o'clock

wild four-o'clock

pony beebalm

evening primrose

broomrape

cancerroot

white prairie clover

penstemon

longleaf phlox

ground cherry

Pecos groundcherry

white polygala

northwest cinquefoil

horse cinquefoil

beauty cinquefoil 


$\begin{array}{ll}\text { Psta } & \text { Psilostrophe tagetina (Nutt.)Greene } \\ \text { Pste } & \text { Psoralea tenuiflora Pursh } \\ \text { Saka } & \text { Salsola kali L. } \\ \text { Sami } & \text { Sanguisorba minor Scop. } \\ \text { SENE } & \text { Senecio spp. } \\ \text { Selo } & \text { Senecio longilobus Benth. } \\ \text { Semu1 } & \text { Senecio multicapitatus Greene } \\ \text { Semu } & \text { Senecio multilobatus T. +G. } \\ \text { Sene1 } & \text { Senecio neonmexicanus Gray } \\ \text { Sisc } & \text { Silene scouleri Hook. } \\ \text { SOLA } & \text { Solanum spp. } \\ \text { Soel } & \text { Solanum eleagnifolium Cav. } \\ \text { Sofe } & \text { Solanum fendleri Gray } \\ \text { Sose2 } & \text { Sophora sericea Nutt. } \\ \text { SPHA } & \text { Sphaeralcea spp. } \\ \text { Spco1 } & \text { Sphaeralcea coccinea (Purhs)Rydb. } \\ \text { Spdi } & \text { Sphaeralcea digitata (Greene)Rydb. } \\ \text { Spin } & \text { Sphaeralcea incana Torr. } \\ \text { STEP } & \text { Stephanomeria spp. } \\ \text { SUAE } & \text { Suaeda spp. } \\ \text { Tala2 } & \text { Taraxacum laevigatum (Willd.)DC. } \\ \text { Tapa1 } & \text { Talinum parviflorum Nutt. } \\ \text { Thal } & \text { Thlaspi alpestre L. } \\ \text { Thme } & \text { Thelesperma megapotamicum } \\ & \text { (Spreng.)Kuntze } \\ \text { Thpi } & \text { Thermopsis pinetorum Greene } \\ \text { Toin } & \text { Townsendia incana Nutt. } \\ \text { TRAD } & \text { Tradescantia spp. } \\ \text { TRAG1 } & \text { Tragapogon spp. } \\ \text { Troc } & \text { Tradescantia occidentalis (Britt.)Smyth } \\ \text { TRIF } & \text { Trifolium spp. } \\ \text { Vebi } & \text { Verbena bipinnatifida Nutt. } \\ \text { Vebr } & \text { Verbena bracteata Lag. + Rodr. } \\ \text { Viam } & \text { Vicia americana Muhl. } \\ \text { Viex } & \text { Vicia exigua Nutt. } \\ \text { VIGU } & \text { Viguiera spp. } \\ \text { VIOL } & \text { Viola spp. } \\ \text { Ziel } & \text { Zigadenus elegans Pursh } \\ \text { Zigr } & \text { Zinnia grandiflora Nutt. } \\ & \\ & \end{array}$

\section{Grasses and Grasslikes}

Agcr Agropyron cristatum (L.) Gaertn.

Agda Agropyron dasytachyum (Hook.)Scribr.

Agde1 Agropyron desertorum (Fisch.)Schult.

Agin Agropyron intermedium (Host)Beauv.

Agsm Agropyron smithii Rydb.

Agsu Agropyron subsecundum (Link)Hitchc.

Agtr1 Agropyron trachycaulum (Link)Malte

Agtr2 Agropyron trichophorum (Link)Richt.

Anha Andropogon hallii Hack.

Ansc Andropogon scoparius Michx.

Arfe1 Aristida fendleriana Steud.

Arlo1 Aristida longiseta Steud.

Bltr Blepharoneuron tricholepis (Torr.)Nash

Boba Bouteloua barbata Lag.

Bocu Bouteloua curtipendula (Michx.)Torr.

Boer Bouteloua eriopoda (Torr.)Torr.

Bogr Bouteloua gracilis (H.B.K.)Steud.

Bohi Bouteloua hirsuta Log.

Brin1 Bromus inermis Leyss. woolly paperflower slimflower scurfpea

Russian thistle

burnet

groundsel

threadleaf groundsel

(multi-flowered) groundsel

(pinnate) groundsel

New Mexico groundsel

scouler silene

nightshade

silverleaf nightshade

fendler potato

silky sophora

globemallow

scarlet globemallow

(two-cleft) globemallow

(yellow) globemallow

wirelettuce

seep weed

red-seeded dandelion

prairie fameflower

white candy tuft

green thread

pine thermopsis

hoary townsendia

spiderwort

salsify

prairie spiderwort

clover

Dakota verbena

bigbract verbena

American vetch

slim vetch

golden eye

violet

mountain deathcamas

Rocky Mountain zinnia

crested wheatgrass

thickspike wheatgrass

desert wheatgrass

intermediate wheatgrass

bluestem wheatgrass

bearded wheatgrass

slender wheatgrass

pubescent wheatgrass

sand bluestem

little bluestem

Fendler threeawn

red threeawn

pine dropseed

six weeks grama

sideoats grama

black grama

blue grama

hairy grama

smooth brome 


\begin{tabular}{|c|c|c|}
\hline Brte & Bromus tectorum L. & cheatgrass brome \\
\hline Buda & Buchloe dactyloides (Nutt.)Engelm. & buffalo grass \\
\hline CARE & Carex spp. & sedge \\
\hline Cafo & Carex foenea Willd. & silvertop sedge \\
\hline CYPE & Cyperus spp. & flatsedge \\
\hline Cysc & Cyperus schweinitzii Torr. & Schweinitz flatsedge \\
\hline Dist & Distichlis stricta (Torr.)Rydb. & inland saltgrass \\
\hline ERAG & Eragrostis spp. & lovegrass \\
\hline Fear & Festuca arizonica Vasey & Arizona fescue \\
\hline Feth & Festuca thurberi Vasey & Thurber fescue \\
\hline Hija & Hilaria jamesii (Torr.)Benth. & galleta \\
\hline Kocr & Koeleria cristata Pers. & prairie junegrass \\
\hline MUHL & Muhlenbergia spp. & muhly \\
\hline Muar1 & Muhlenbergia arenicola Buckl. & sand muhly \\
\hline Mufi1 & Muhlenbergia filiculmis Vasey & slimstem muhly \\
\hline Mumo & Muhlenbergia montana Nutt.Hitchc. & mountain muhly \\
\hline Mure & Muhlenbergia repens (Presl)Hitchc. & red muhly \\
\hline Mupo & Muhlenbergia porteria Scribn. & bush muhly \\
\hline Muri1 & Muhlenbergia richardsonis (Trin.) Rydb. & mat muhly \\
\hline Mupu & Muhlenbergia pungens Thurb. & sandhill muhly \\
\hline Muto & Muhlenbergia torreyi (Kunth)Bush & ring muhly \\
\hline Muwr & Muhlenbergia wrightii Vasey & spike muhly \\
\hline Musq & Munroa squarrosa (Nutt.)Torr. & false buffalograss \\
\hline Orhy & Oryzopsis hymenoides (R. + S.) Richer & Indian ricegrass \\
\hline Paob & Panicum obtusum H.B.K. & vine mesquite \\
\hline POA & Poa spp. & bluegrass \\
\hline Pofe & Poa fendleriana (Steud.)Vasey & mutton bluegrass \\
\hline Popa & Poa palustris L. & fowl bluegrass \\
\hline Pose & Poa secunda Presl. & \\
\hline Scbr & Scleropogon brevifolius Phil. & $\begin{array}{l}\text { bandoerg DI } \\
\text { burrograss }\end{array}$ \\
\hline Sihy & Sitanion hystrix (Nutt.) J.G.Sm. & bottlebrush squirreltail \\
\hline SPÖR & Sporobolus spp. & dropseed \\
\hline Spai & Sporobolus airoides (Torr.)Torr. & alkali sacaton \\
\hline Spas & Sporobolus asper (Michx.)Kunth & tall dropseed \\
\hline Spco & Sporobolus contractus Hitchc. & spike dropseed \\
\hline Spcr & Sporobolus cryptandrus (Torr.)Gray & sand dropseed \\
\hline Spfl & Sporobolus flexuosus (Thrub.)Rydb. & mesa dropseed \\
\hline Spgi & Sporobolus gigantea Nash & giant dropseed \\
\hline Spne1 & Sporobolus nealleyi Vasey & gypgrass \\
\hline STIP & Stipa spp. & needlegrass \\
\hline Stco1 & Stipa comata Trin. + Rupr. & needle and thread \\
\hline Stle & Stipa lettermanii Vasey & letterman needlegrass \\
\hline Stne & Stipa neomexicana (Thrub.)Sc & New Mexico feathergla \\
\hline Stro & Stripa robusta (Vasey)Scribn. & sleepy grass \\
\hline
\end{tabular}




\section{APPENDIX C}

Key to the plant communities (p.c.) of the Upper Rio Puerco Watershed, New Mexico

1a. Plant community with a tree synusia (layer) dominant or conspicuous consisting of Pipo (Pinus ponderosa), Pied (Pinus edulis), and/or Jumo (Juniperus monosperma)

1b. Plant community without a tree synusia; dominated by shrubs and/or grasses

2a. Pipo dominant, co-dominant, or conspicuous

.. 3

2b. Pipo not dominant or conspicuous

$\ldots 4$

3a. Pipo synusia with CARE (Carex spp.) and/or Bogr (Bouteloua gracilis) as the dominant understory synusia; occurring on mesas or colluvial slopes; soils shallow, loamy

...Pinus ponderosa/Carex spp.-Bouteloua gracilis

(Pipo/CARE-Bogr; ponderosa pine/sedge-blue grama)

3b. Pipo dominant with Pied co-dominant or conspicuous; Bogr and CARE as the dominant understory synusia; occurring on mesas; soils shallow, loamy ...Pinus ponderosa - P. edulis/Bouteloua gracilis Carex spp.

(Pipo-Pied/Bogr-CARE; ponderosa pine-pinyon pine/ blue grama-sedge)

4a. Pied dominant or conspicuous

4b. Jumo dominant or conspicuous

5a. Pied dominant or conspicuous with Bogr and/or ERIO (Eriogonum spp.) dominating the understory synusia; occurring on steep, rocky colluvial slopes; soils shallow, sandy-clay loam ...Pinus edulis/Bouteloua gracilis-Eriogonum spp. (Pied/Bogr-ERIO; pinyon pine/blue grama-buckwheat)

5b. Pied co-dominant with Jumo or Quga (Quercus .. gambelii)

6a. Pied co-dominant with Jumo; Oppo (Opuntia polyacantha) and/or Bogr dominant or conspicuous understory synusia components; occurring on mesas; soils shallow, stoney-clay loam or basalt outcrops ...Pinus edulis-Juniperus monosperma/Opuntia polyacantha/Bouteloua gracilis (Pied-Jumo/Oppo/Bogr; pinyon pine-one-seed juniper/ pricklypear cactus/blue grama)

6b. Pied co-dominant with Quga; Hija (Hilaria jamesii) and/or Spne (Sporobolus nealleyi) as dominant or conspicuous understory synusia components; occurring on mesas; soils gypsum-sandstone-shale outcrops ...Pinus edulis/Quercus gambelii/Hilaria jamesiiSporobolus neallyii (Pied/Quga/Hija-Spne; pinyon pine/gambel oak/ galleta-gypgrass) 
7a. Jumo dominant or conspicuous w/o a shrub synusia; Bogr dominating the understory synusia; occurring on breaks or colluvial slopes; soils shallow, loamy sand-clay

...Juniperus monosperma/Bouteloua gracilis

(Jumo/Bogr; one-seed juniper/blue grama)

7b. Jumo dominant or conspicuous; Gusa (Gutierrezia sarothrae) or Artr (Artemisia tridentata) as a shrub synusia

8a. Jumo dominant or conspicuous with Gusa as the major shrub component; Bogr and/or Hija dominating the understory synusia; occurring on breaks or colluvial slopes; soils shallow, silty-clay loam ...Juniperus monosperma/Gutierrizia sarothrae/ Bouteloua gracilis-Hilaria jamesii (Jumo/Gusa/Bogr-Hija; one-seed juniper/snakeweed/ blue grama-galleta)

8b. Jumo dominant or conspicuous with Artr as the major shrub component; Hija and/or Spcr (Sporobolus cryptandrus) dominating the understory synusia; occurring on mesas; soils shallow, fine-loamy .. Juniperus monosperma/Artemisia tridentatal Hilaria jamesii-Sporobolus cryptandrus (Jumo/Artr/Hija-Spcr; one-seed juniper/big sagebrush/galleta-sand dropseed)

9a. Plant community dominated by or with a conspicuous shrub synusia

9b. Plant community w/out a conspicuous shrub synusia; dominated by graminoids; Gusa may be a dominant component

10a. Artemisia dominant, co-dominant, or conspicuous

10b. Artemisia not conspicuous

11a. Artr dominant, co-dominant, or conspicuous

11b. Arno (Artemisia nova) dominant, co-dominant, or conspicuous

12a. Artr dominant

12b. Artr co-dominant

13a. Artr dominant or conspicuous; Spcr and/or Orhy (Oryzopsis hymenoides) dominating the understory synusia; occurring on alluvial flats; soils shallow, loamy ...Artemisia tridentata/Sporobolus cryptandrus-Oryzopsis hymenoides (Artr/Spcr-Orhy; big sagebrush/sand dropseed-Indian ricegrass)

13b. Artr dominant or conspicuous; Bogr dominant or co-dominant in the understory synusia

14a. Artr dominating the shrub synusia; Bogr and/or Hija co-dominating the understory synusia; occurring on mesas or alluvial flats; soils deep, sandy to fineloam 
...Artemisia tridentata/Bouteloua gracilis-Hilaria jamesii

p.c.9

(Artr/Bogr-Hija; big sagebrush/blue grama-galleta)

14b. Artr dominating the shrub synusia; Bogr, Hija, and/or Spai (Sporobolus airoides) co-dominating the understory synusia; occurring on alluvial flats; soils deep, fine to course loam ...Artemisia tridentata/Bouteloua gracilisHilaria jamesii-Sporobolus airoides (Artr/Bogr-Hija-Spai; big sagebrush/blue gramagalleta-alkali sacaton)

15a. Artr co-dominant with Chpa (Chrysothamnus parryi); Arfe (Aristida fendleriana) and/or Bogr co-dominating the understory synusia; occurring on alluvial flats; soil deep, clayey ...Artemisia tridentata-Chrysothamnus parryi/Aristada fendleriana-Bouteloua gracilis (Artr-Chpa/Arfe-Bogr; big sagebrush-Parry rabbitbrush/ Fendler threeawn-blue grama)

15b. Artr co-dominant with Gusa

16a. Artr and Gusa co-dominant, or Gusa conspicuous; Hija and Spai dominant understory components; Bogr minor; occurring on colluvial or alluvial slopes; soils deep, fine-loamy ...Artemisia tridentata-Gutierrezia sarothrae/ Hilaria jamesii-Sporobolus airoides (Artr-Gusa/Hija-Spai; big sagebrush-snakeweed/ galleta-alkali sacaton)

16b. Artr and Gusa co-dominant, or Gusa conspicuous; Bogr dominating the understory synusia

17a. Bogr dominant or co-dominant with Hija; occurring on mesas or alluvial flats; soils deep, fine-loam ...Artemisia tridentata-Gutierrezia sarothrael Bouteloua gracilis-Hilaria jamesii (Artr-Gusa/Bogr-Hija; big sagebrush-snakeweed/ blue grama-galleta)

17b. Bogr dominant or co-dominant with Agsm (Agropyron smithii) occurring on alluvial flats; soils deep, fine-loamy ...Artemisia tridentata-Gutierrezia sarothrae/ Bouteloua gracilis-Agropyron smithii (Artr-Gusa/Bogr-Agsm; big sagebrush-snakeweed/ blue grama-western wheatgrass)

18a. Arno and Artr co-dominant; Agcr (Agropyron cristatum) and/or Agsm co-dominanting the understory synusia; occurring on alluvial flats; soils deep, clay to clay-loam ...Artemisia nova-A. tridentata/Agropyron cristatum-Agropyron smithii (Arno-Artr/Agcr-Agsm; black sagebrush-big sagebrush/crested wheatgrass-western wheatgrass) 
18b. Arno and Gusa co-dominant or Gusa conspicuous;

Bogr and/or Hija dominating the understory

synusia; occurring on breaks; soils shallow, sandy-loam or clayey

... Artemisia nova-Gutierrezia sarothrae/

Bouteloua gracilis-Hilaria jamesii

(Arno-Gusa/Bogr-Hija; black sagebrushsnakeweed/blue grama-galleta)

19a. Chrysothamnus dominant or conspicuous

. . 20

19b. Chrysothamnus not dominant

... 22

20a. Chpa dominant or conspicuous; Hija and/or Bogr

dominant in the understory synusia; occurring

on alluvial flats; soils deep, sandy to loamy

... Chrysothamnus parryi/Hilaria jamesii-

Bouteloua gracilis

(Chpa/Hija-Bogr; Parry rabbitbrush/galleta-blue grama)

20b. Chna (Chrysothamnus nauseosus) dominant or conspicuous; Bogr and/or Agsm dominating the understory synusia

21a. Chnab dominant; occurring on alluvial flats; soils moderately deep, silty loam ... Chrysothamnus nauseosus bigelovii/

Bouteloua gracilis-Agropyron smithii

(Chnab/Bogr-Agsm; Bigelow rubber rabbit-

p.c.18

brush/blue grama-western wheatgrass)

21b. Chnag dominant; occurring on alluvial flats;

soils deep, fine-silty-clay loam

... Chrysothamnus nauseosus graveolens/Bouteloua

gracilis-Agropyron smithii

p.c. 20

(Chnag/Bogr-Agsm; green plume rubber rabbit-

brush/blue grama-western wheatgrass)

22a. Save (Sarcobatus vermiculatus) dominant or conspicuous $\ldots 23$

22b. Save not dominant

23a. Save dominant as a monospecific community; occurring on alluvial flats; soils deep, clayey

...Sarcobatus vermiculatus

(Save; black greasewood)

23b. Save dominant; Sihy (Sitanion hystrix) and/or Agsm

dominating the understory synusia; occurring on

alluvial flats; soils deep, clayey

...Sarcobatus vermiculatus/Sitanion hystrix-

Agropyron smithii

p.c. 22

(Save/Sihy-Agsm; black greasewood/bottlebrush

squirreltail-western wheatgrass)

24a. Ceratoides dominant, Gusa co-dominant or conspicuous

24b. Ceratoides not dominant

25a. Hija dominating the understory synusia; occurring on alluvial flats; soils moderately deep, loamy 
...Ceratoides lanata-Gutierrezia sarothrae/Hilaria jamesii

(Cela-Gusa/Hija; winterfat-snakeweed/galleta)

25b. Bogr dominating the understory synusia; occurring on alluvial flats and mesas; soils moderately deep, silty-clay loam

...Ceratoides lanata-Gutierrezia sarothrae/Bouteloua gracilis

(Cela-Gusa/Bogr; winterfat-snakeweed/blue grama)

26a. Atriplex dominant or conspicuous

26b. Atriplex not dominant

27a. Atcu (Atriplex cuneata) and Frja (Frankenia jamesii) dominant, co-dominant, or conspicuous; Spai dominant grass component; occurring on colluvial slopes; soils shallow, sandy to silty clay loam ...Atriplex cuneata-Frankenia jamesii/Sporobolus airoides

(Atcu-Frja/Spai; moundscale-Frankenia/alkali sacaton)

27b. Atob (Atriplex obovata) or Atca (Atriplex canescens) dominant or conspicuous

28a. Atob and/or Gusa dominant

28b. Atca and/or Gusa dominant

29a. Atob dominant or conspicuous; Spai and/ or Spcr (Sporobolus cryptandrus) dominating the grass component; occurring on alluvial flats; soils deep, clay-loam ... Atriplex obovata/Sporobolus airoidesSporobolus cryptandrus (Atob/Spai-Spcr; broadscale/alkali sacatonsand dropseed)

29b. Atob and Gusa co-dominant or conspicuous; $\mathrm{Hija}$ and/or Spai dominating the grass component; occurring on alluvial flats; soils shallow, sandy-loam to clay loam . . Atriplex obovata - Gutierrezia sarothrae/ Hilaria jamesii-Sporobolus airoides (Atob-Gusa/Hija-Spai; broadscale-snakeweed/ galleta-alkali sacaton)

30a. Atca and Gusa co-dominant or conspicuous; Bogr and/or Spcr dominant grasses; occurring on alluvial flats; soil deep, loamy-sand to clay ...Atriplex canescens-Gutierrezia sarothrae/ Bouteloua gracilis-Sporobolus cryptandrus (Atca-Gusa/Bogr-Spcr; fourwing saltbushsnakeweed/blue grama-sand dropseed)

30b. Atca dominant or conspicuous

31a. Hija the dominant grass; occurring on alluvial flats; soils deep, silty- 
sandy clay loam

...Atriplex canescens/Hilaria jamesii

(Atca/Hija; fourwing saltbush/galleta)

31b. Spai and/or Sihy the dominant grass(es); occurring on alluvial flats; soils deep, loamy

... Atriplex canescens/Sporobolus

airoides-Sitanion hystrix

(Atca/Spai-Sihy; fourwing saltbush/

alkali sacaton-bottlebrush

squirreltail)

32a. Bouteloua and/or Gusa dominant, co-dominant, or conspicuous... 33

32b. Bouteloua not dominant

33a. Boer (Bouteloua eriopoda) and/or Gusa dominant, co-dominant, or conspicuous; Hija a major component; occurring on mesas; soils shallow to moderately deep, loamy to clay-loam

...Gutierrezia sarothrae/Bouteloua eriopoda-

Hilaria jamesii

(Gusa/Boer-Hija; snakeweed/black grama-galleta)

33b. Bogr and/or Gusa dominant, co-dominant, or conspicuous

34a. Bogr dominant; Gusa a very minor component

34b. Bogr and/or Gusa dominant, co-dominant, or conspicuous

35a. Hija co-dominant or conspicuous; occurring on alluvial flats; soils deep, silty-clay-loam ...Bouteloua gracilis-Hilaria jamesii (Bogr-Hija; blue grama-galleta)

35b. Spai co-dominant or conspicuous; occurring on mesas; soils moderately deep, clay ...Bouteloua gracilis-Sporobolus airoides

(Bogr-Spai; blue grama-alkali sacaton)

36a. Bogr and/or Gusa dominant, co-dominant, or conspicuous; Hija a major component; occurring on mesas and alluvial flats; soils moderately deep, loamy ...Gutierrezia sarothrae/Bouteloua gracilis-Hilaria jamesii

(Gusa/Bogr-Hija; snakeweed/blue gramagalleta)

36b. Bogr and/or Gusa dominant, co-dominant, or conspicuous; Boer a major component; occurring on colluvial slopes; soils shallow, stoney-clay-loam ...Gutierrezia sarothrae/Bouteloua gracilis-B. eriopoda

(Gusa/Bogr-Boer; snakeweed/blue gramablack grama) 
37b. Hija not dominant

38a. Hija and/or Spai dominant, co-dominant, or conspicuous; Gusa a minor component; occurring on alluvial flats; soils moderately deep, fine-loam ... Hilaria jamesii-Sporobolus airoides (Hija-Spai; galleta-alkali sacaton)

38b. Hija and/or Gusa dominant, co-dominant, or conspicuous

39a. Bogr a major component occurring on colluvial slopes or alluvial flats; soils shallow to moderately deep, fine loam to fine silt ...Gutierrezia sarothrae/Hilaria jamesii Bouteloua gracilis (Gusa/Hija-Bogr; snakeweed/galleta-blue grama)

39b. Spcr (Sporobolus cryptandrus) a major component; occurring on alluvial flats; soils moderately deep, silty-clay-loam ...Gutierrezia sarothrae/Bouteloua gracilisSporobolus cryptandrus (Gusa/Bogr-Spcr; snakeweed/blue grama-sand dropseed)

40a. Scleropogon dominant or co-dominant; occurring on alluvial flats; soils deep, clay-loam ...Sclerpogon brevifolius-Bouteloua gracilis (Scbr-Bogr; burrograss-blue grama)

40b. Sporobolus and/or Gusa dominant, co-dominant, or conspicuous

41a. Spne and/or Boer dominant, co-dominant, or conspicuous; occurring on mesas; soils shallow, gypsum ...Sporobolus nealleyi-Bouteloua eriopoda (Spne/Boer; gypgrass-black grama)

41b. Spai and/or Gusa dominant, co-dominant or conspicuous . . 42

42a. Spai and/or Gusa dominant, co-dominant, or conspicuous; Hija a major component; occurring on alluvial flats; soils moderately deep, sandy/silty-clay-loam ....Gutierrezia sarothrae/Sporobolus airoidesHilaria jamesii

(Gusa/Spai-Hija; snakeweed/alkali sacatongalleta)

42b. Spai dominant or co-dominant; Gusa a very minor component, if at all

43a. Spai dominating essentially monospecific communities on alluvial flats ...Sporobolus airoides (Spai; alkali sacaton) 
43b. Spai dominant or co-dominant with Bogr, Hija, or Agsm; occurring on alluvial flats; soils deep, silty-clay-loam ... Sporobolus airoides-Bouteloua gracilis (Spai-Bogr; alkali sacaton-blue grama)

...S. airoides-Hilaria jamesii

(Spai-Hija; alkali sacaton-galleta)

p.c. 41

...S. airoides-Agropyron smithii

(Spai-Agsm; alkali sacaton-wheatgrass)

p.c. 43

\section{APPENDIX D}

Terminology

Amplitude, Ecological: Plant species range of external physical [and biological] environmental conditions [necessary] for growth (Shimwell 1972).

Climax: A stable, perpetuating plant community in equilibrium with its environment (Daubernmire 1968). Pristine vegetation is not implied.

Community-type (c.t.): An abstract concept based upon the knowledge of the nature of several similar community stands (Shimwell 1972). Community-type is analogous to the association in a hierarchy, but successional stage is not implied; ie: c.t. may or may not be stable (climax).

Degraded Site: A homogenous area which has been reduced in ecological potential through erosion and/or severe overuse.

Diversity, Ecological: The number of species (species richness) in relation to their [spatial] distribution (concept of evenness, Margalef 1958) (Pielou 1974). Beta = between-habitat diversity; alpha = within-habitat diversity (Whittaker 1975).

Dominance: The degree of [structural and/or functional] influence exerted over other species within a community (Greig-Smith 1983).

Effective soil: Zone of maximum organic matter accumulation and nutrient content for plant growth; usually the A- and B-horizons.

Formation: A hierarchical vegetation class determined by its dominant physiognomic life-form; i.e., treeland, shrubland, grassland (UNESCO 1973, Brown et al. 1979).

Grassland: An area on which the vegetation is dominated by herbaceous plants (Powell 1982).
Niche, Ecological: The totality of sets of conditions that are compatible with a species persistence and success (Pielou 1974) including both structural and functional relationships.

Plant Community (p.c.): An organized complex with a typical floristic composition and morphological structure which have resulted from the interaction of species populations [edaphic, and climatic factors] through time (Shimwell 1972).

Phyto-Edaphic Community:An abstract ecological unit based on concrete plant (phyto) and soil (edaphic) characteristics analogous to habitat type (Daubenmire 1968) but without implied successional status.

Potential Natural Vegetation: Hypothetical, stable plant community based on existing vegetation projected into some undefined future accounting for current site conditions and minimum human disturbance (MuellerDombois and Ellenberg 1974, Schlatterer 1978).

Series: A hierarchical vegetation class determined by its dominant species regardless of life-form (Mueggler and Stewart 1980, Brown et al. 1982, Driscoll et al. 1984); stability is implied. In the context of this paper, stability is not implied and perhaps the term subseries should be used as a seral equivalent.

Shrubland: An area on which the vegetation is dominated by shrubs (Powell 1982).

Site: A homogenous, concrete landscape unit used as a sample area for vegetation and soil.

Stand: A concrete example of a community located in the field used for study (Shimwell 1972).

Subformation: A hierarchical vegetation class determined by its dominant genus (Adapted from DuRietz 1930).

Treeland: An area on which the vegetation is dominated by trees (Powell 1982). Treeland is used in this paper as an ecological lifeform equivalent to grassland and shrubland rather than the traditional use of the term forest. 



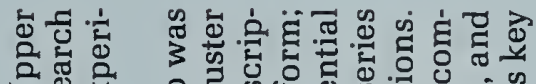
ऽ品

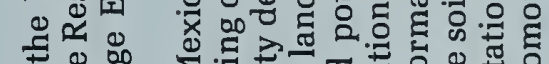

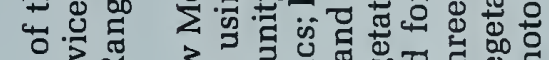
\&

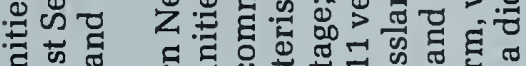
ఏ 屯 药范 हี

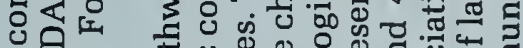
uํㅖ

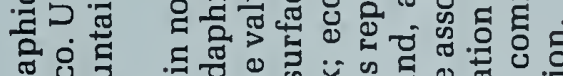
它.

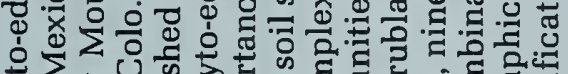

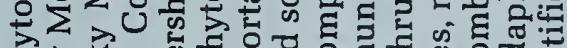

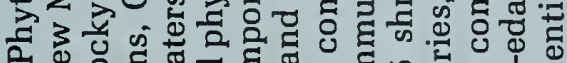

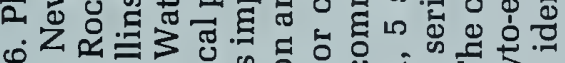
० 可

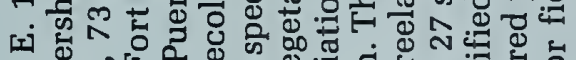

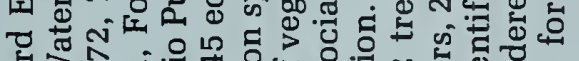

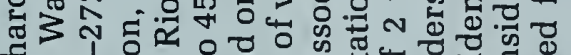

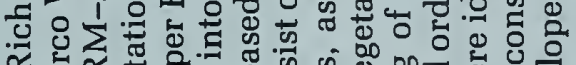

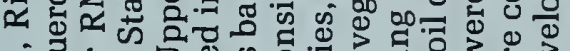

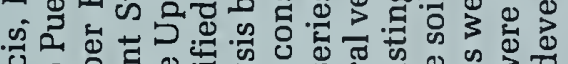

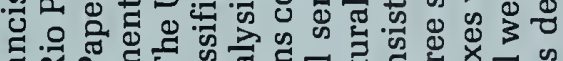

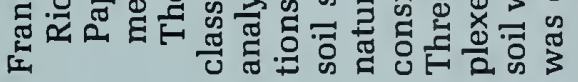

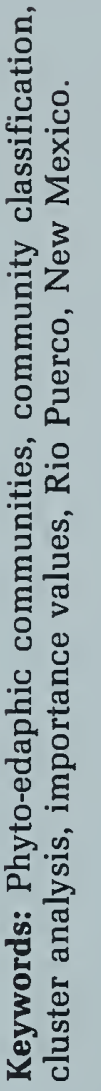

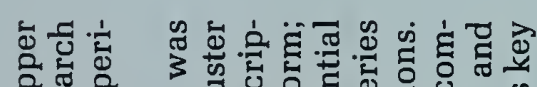
ऽ卷 어

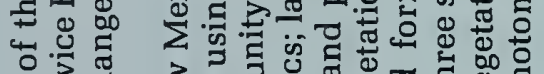

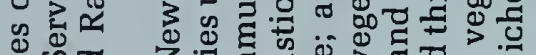

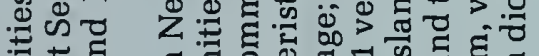

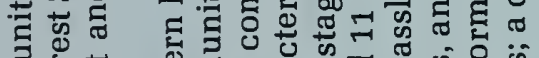
हैं ส대유

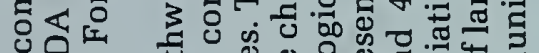

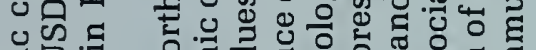

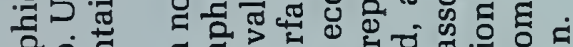

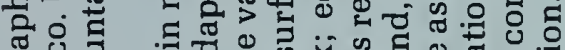

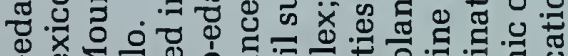

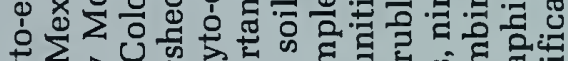

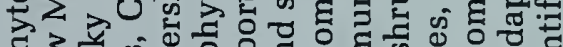

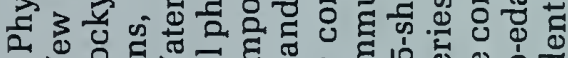

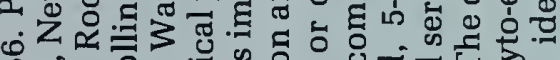
\%

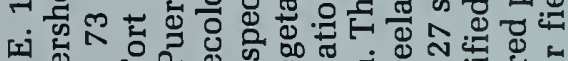
ช

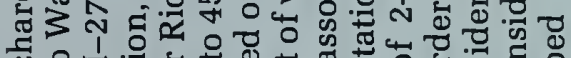

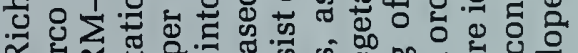

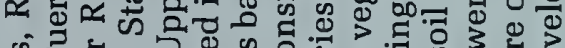

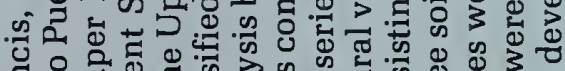

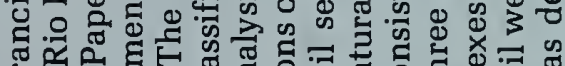

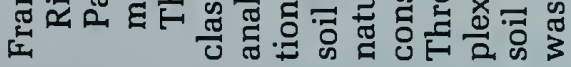

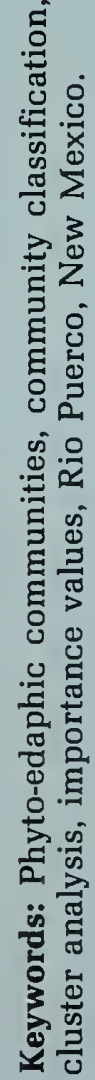

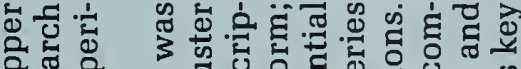

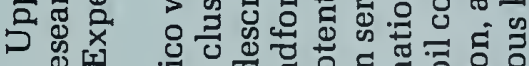
क्षा 曲 फ. is 2

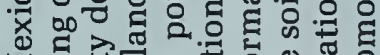

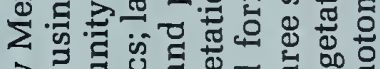

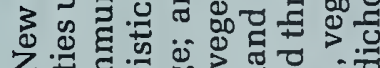
范

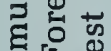
乙记 है:

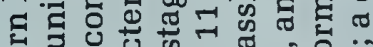
बै

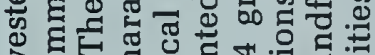

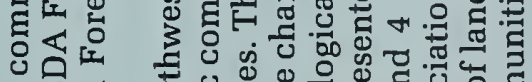
.

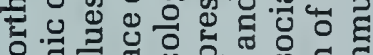
ㄱำ

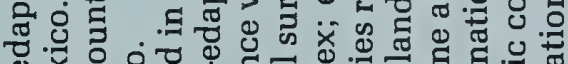

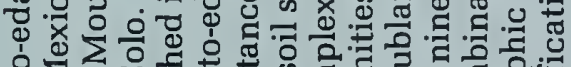

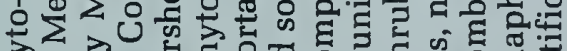

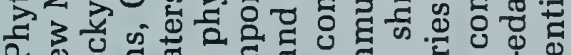

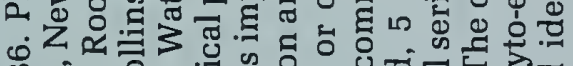

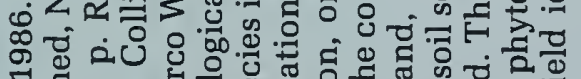

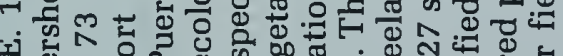
ช

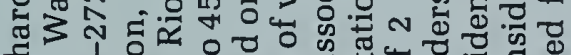

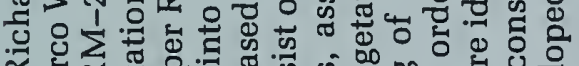

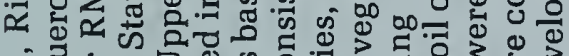

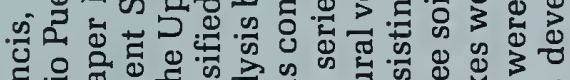

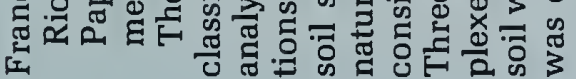




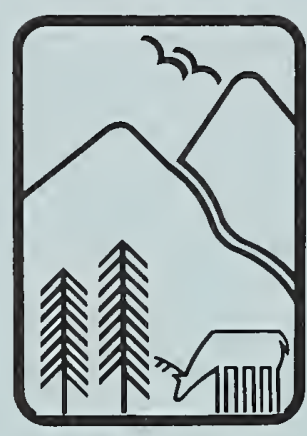

Rocky Mountains

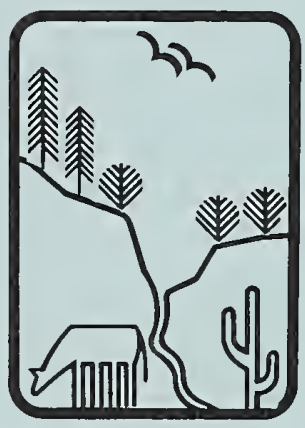

Southwest

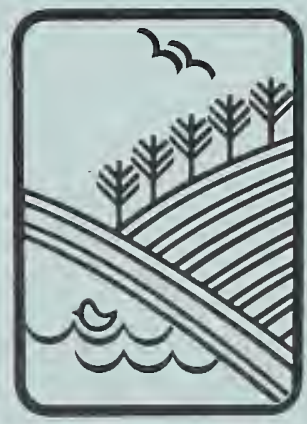

Great Plains
U.S. Department of Agriculture Forest Service

\section{Rocky Mountain Forest and} Range Experiment Station

The Rocky Mountain Station is one of eight regional experiment stations, plus the Forest Products Laboratory and the Washington Office Staff, that make up the Forest Service research organization.

\section{RESEARCH FOCUS}

Research programs at the Rocky Mountain Station are coordinated with area universities and with other institutions. Many studies are conducted on a cooperative basis to accelerate solutions to problems involving range, water, wildlife and fish habitat, human and community development, timber, recreation, protection, and multiresource evaluation.

\section{RESEARCH LOCATIONS}

Research Work Units of the Rocky Mountain Station are operated in cooperation with universities in the following cities:

Albuquerque, New Mexico

Flagstaff, Arizona

Fort Collins, Colorado*

Laramie, Wyoming

Lincoln, Nebraska

Rapid City, South Dakota

Tempe, Arizona

"Station Headquarters: 240 W. Prospect St., Fort Collins, CO 80526 